Schriften zum Internationalen und

Europäischen Strafrecht

Francisco Schertel Mendes

Leniency Policies in the Prosecution of Economic Crimes and Corruption

Consensual Justice and Search for Truth in Brazilian and German Law 
Schriften zum Internationalen und

Europäischen Strafrecht

Herausgegeben von

Professor Dr. Martin Heger, Humboldt-Universität zu Berlin

Professor Dr. Florian Jeßberger, Humboldt-Universität zu Berlin

Professor Dr. Frank Neubacher, M.A., Universität zu Köln

Professor Dr. Helmut Satzger, LMU München

Professor Dr. Gerhard Werle, Humboldt-Universität zu Berlin

Band 48 
Francisco Schertel Mendes

\section{Leniency Policies in the Prosecution of Economic Crimes and Corruption}

Consensual Justice and Search for Truth in Brazilian and German Law 
The Deutsche Nationalbibliothek lists this publication in the Deutsche Nationalbibliografie; detailed bibliographic data are available on the Internet at http://dnb.d-nb.de

a.t.: Berlin, HU, Diss., 2020

$\begin{array}{ll}\text { ISBN } & 978-3-8487-7849-2 \text { (Print) } \\ 978-3-7489-2259-9 & \text { (ePDF) }\end{array}$

British Library Cataloguing-in-Publication Data

A catalogue record for this book is available from the British Library.

ISBN

978-3-8487-7849-2 (Print)

978-3-7489-2259-9 (ePDF)

\section{Library of Congress Cataloging-in-Publication Data}

Schertel Mendes, Francisco

Leniency Policies in the Prosecution of Economic Crimes and Corruption

Consensual Justice and Search for Truth in Brazilian and German Law

Francisco Schertel Mendes

345 pp.

Includes bibliographic references.

ISBN 978-3-8487-7849-2 (Print)

978-3-7489-2259-9 (ePDF)

1st Edition 2021

(C) Francisco Schertel Mendes

Published by

Nomos Verlagsgesellschaft mbH \& Co. KG

Waldseestraße 3-5 | 76530 Baden-Baden

www.nomos.de

Production of the printed version:

Nomos Verlagsgesellschaft $\mathrm{mbH} \& \mathrm{Co}$. KG

Waldseestraße 3-5 | 76530 Baden-Baden

ISBN (Print): 978-3-8487-7849-2

ISBN (ePDF): 978-3-7489-2259-9

DOI: https://doi.org/10.5771/9783748922599

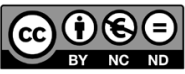

This work is licensed under a Creative Commons Attribution

- Non Commercial - No Derivations 4.0 International License. 
To Rosa, for a lifetime of extraordinary lessons. 
"To be free of an erroneous opinion (...) one must at some time have professed it."

Jorge Luis Borges, Averroes' Search. 


\section{Preface}

This book is the result of a doctoral research carried out before the Humboldt University of Berlin and the University of Brasilia between 2014 and 2018. After the defense of the thesis, in 2019 , only minor terminological adjustments were made.

The research started as an inquiry into the possibilities of improvement and strengthening of leniency policies in the prosecution of economic offenses., a subject with which I have been occupied for some time. Between 2009 and 2014, I worked for the Brazilian Competition Authority, and there I had the opportunity to steer a wide policy reform to enhance the use of cooperating defendants in Brazilian anti-cartel enforcement. Coming from this background, the original research project had a narrow and inward-looking approach, as commonly found in the official discourse regarding leniency policies.

The research changed course when several aspects of the recent use of cooperating defendants in Brazilian criminal investigations proved, once analyzed from a comparative perspective, to be highly inventive and somewhat eccentric. I am extremely grateful to my supervisor, Professor Dr. Martin Heger, who gave solid advice for the development of a critical stance towards the subject. His enthusiasm and trust in the research played a pivotal role in the development of the thesis.

I am also thankful to Professor Dr. Luís Greco, who supported the research from the beginning and offered me the opportunity to discuss the thesis in the "Rechtsphilosophisches Donnerstag-Seminar," at the Faculty of Law of Humboldt University. I am as well obliged to Professor Ana Frazão, who co-supervised the thesis and provided valuable guidance, and Professor Paulo Burnier, who contributed to the research in many ways. I also express my gratitude to my friends Robert Pest and Alaor Leite, who have always provided a safe harbor in Berlin.

This thesis has been written - over four years and sometimes under challenging circumstances - in Berlin, Brasília, and Maastricht. All along, the love and support of Lorena Coutinho transformed a rough challenge into an incredible journey, full of joy, warmth, and affection. 


\section{Contents}

$\begin{array}{ll}\text { Abbreviations } & 15\end{array}$

$\begin{array}{ll}\text { Introduction } & 17\end{array}$

Chapter I - The development of leniency policies in Brazilian criminal justice and the contractualist approach to collaboration agreements $\quad 29$

1. Introduction

2. The Brazilian procedural tradition and the recent development of leniency policies

a. Competition law 37

b. Criminal law 41

3. The legal structure of Brazilian leniency policies 46

a. The negotiation dynamic: consensual arrangements, written agreements and informal communication $\quad 48$

b. Terms of trade 51

i. Benefits: immunities and reduction of penalties 51

ii. Duties: cooperation with the investigations 54

c. Signing and fulfillment of the agreement 56

4. The inventive practice of collaboration agreements: development and judicial support 58

a. Law in action, consensual innovations and the expansion of the room for negotiations $\quad 58$

i. Granting of benefits not provided for by law 61

ii. Exact definition of imprisonment penalties 65

iii. Package deals and "unified punishment" 67

iv. The serving of imprisonment penalties in advance $\quad 70$

b. Contractual freedom, tailor-made arrangements and unique consensual solutions

c. A new model of criminal procedure? Collaboration agreements and consensual criminal justice

i. The binding effect of collaboration agreements: pacta sunt servanda in criminal procedure 
ii. The principle of "res inter alios acta" and the prohibition of legal challenges by third parties

5. Conclusion: a contractualist approach to collaboration agreements

Chapter II - Collaboration agreements and macro-delinquency in Brazilian recent experience: notable results in the prosecution of corruption networks

1. Introduction

2. Operation Car Wash

3. Corruption networks

a. Collective goods, diffuse losses 96

b. Legitimate and sophisticated organizations 98

c. Major impacts on social life

102

4. Storming the castle: macro-delinquency, consensual justice and public support for leniency policies

5. Conclusion: the will and the way for the practice of collaboration agreements

Chapter III - Leniency policies: rationale, expectations and risks

1. Introduction

2. The rationale and expectations of leniency policies: optimal deterrence through increased detection and prevention

a. Detection of crimes and gathering of evidence

b. Prevention of illegal activities

3. Principal-agent relationships, information asymmetry and the risks of leniency policies

a. Misrepresentation of facts: under- and over-cooperation

b. The dark side of leniency: amnesty effect, recidivism and the need for limits

c. Distortion of incentives for enforcement authorities: leniency over-reliance, statistical boost and the overheated market for cooperation

d. Gaming the leniency system: repeated games, sophisticated agents and reverse exploitation

4. Conclusion: leniency revolution and leniency religion 
Chapter IV - Consensual exchanges in German criminal procedure: the practice of negotiated judgments and the crownwitness regulation

1. Introduction

2. Negotiated judgments: practice and regulation

a. Search for truth, compulsory prosecution and consent in the German tradition

b. Development of the practice of negotiated judgments

c. Judicial acknowledgement

d. The legislative regulation of negotiated judgments

e. The 2013 ruling of the German Constitutional Court

3. The general crown-witness regulation

a. Development

b. Structure

c. Scope of application: investigative emergencies

d. Investigative achievements, essential contributions and positive balances

e. Inside and outside cooperators: the issue of the connection requirement

4. Points of analysis

a The prosecution of economic crimes: between consent and search for truth

i. Negotiated judgments and crown-witness regulation: parallels and differences

ii. Consent and search for truth: different answers to similar questions? Disenchantment and re-enchantment with truth-finding in criminal procedure

b. Expansion of the negotiation forum, externalities and abstinence from the search for truth

i. The tension over the boundaries of the room for negotiation and the troublesome taming of negotiated judgments

ii. Negative externalities and abstinence from the search for truth

iii. The 2013 ruling of the German Federal Constitutional Court and the case-law of the U.S. Supreme Court: unnoticed virtues? 
Chapter V - Truth and consent in collaboration agreements: a rebuff to the contractualist approach

1. Introduction

2. The practice of collaboration agreements: incompatibility with Brazilian criminal justice and counterproductive effects

a. Collaboration agreements as exceptional tools for investigative emergencies

b. Due process, search for truth and the chain of events in criminal procedure

c. Separation of functions in criminal procedure: the return of the inquisitorial process?

d. Investigative achievements, information asymmetry and the risks of forward purchases in the practice of collaboration agreements

3. Collaboration agreements as public-private partnerships within criminal justice: the privatization of truth-finding and its effect on third parties

a. Triangular relationships, not bilateral transactions

b. Collaboration agreements as mechanism of consensual justice? Disenchantment and reenchantment with truth-searching in criminal procedure

c. Collaboration agreements as public-private partnerships and the privatization of official investigations

d. Is there a Brazilian system of plea bargaining? Legal transplants, legal translations and legal counterfeits

e. The contractual redesign of Brazilian criminal law

4. The judicial control of collaboration agreements

a. Pacta sunt servanda or nemo dat quod non habet? The issue of the binding effect

b. Negative externalities, private gains and social costs: the distorted use of collaboration agreements as hedging mechanisms

c. The overheated cooperation market and the problem of monopoly of selection: a case for broad and in-depth judicial control of collaboration agreements

5. Conclusion: the contractualist approach from a comparative perspective 
a. The right of third parties to question collaboration agreements in court: protection of individual rights and of the public interest

b. The array of leniency benefits: a case for numerus clausus

c. The guarantee of equal treatment and the bazaar of punishment

d. Disclosure and confidentiality: cooperators as the monopolists of truth

e. Advanced enforcement of penalties and the paradox of investigating what has already been determined

f. Preparatory acts, the control of the negotiation process and the duty to register

3. Governing through white-collar crime: collaboration agreements and the fight against corruption

a. Collaboration agreements, the anti-corruption movement and the dynamic of "governing through crime"

b. Under the law, above the law

c. Investigative achievements, failures and the effectiveness discourse: collaboration religion?

$\mathrm{d}$. The symbiotic relationship between collaboration agreements and the Brazilian anti-corruption movement

4. Conclusion: a prosperous life for consensual mechanisms in Brazilian criminal justice

Conclusion

Annex - List of collaboration agreements analyzed

References 


\section{Abbreviations}

\section{German Courts}

BGH - Bundesgerichtshof (Federal Court of Justice)

BVerfG - Bundesverfassungsgericht (Federal Constitutional Court)

Deutscher Bundestag - German Parliament

\section{Brazilian Courts}

JFDF - Federal Justice of the Federal District

JFPR - Federal Justice of the State of Paraná

STF - Supremo Tribunal Federal (Federal Supreme Court)

STJ - Superior Tribunal de Justiça (Superior Court of Justice)

TRF4 - Appeal Court of the 4th Circuit of the Federal Justice MPF - Federal Public Prosecution Office 


\section{Introduction}

Over recent decades, there has been a clear movement in numerous countries towards expanding the use of leniency policies in the prosecution of different types of wrongdoing. ${ }^{1}$ Leniency policies establish that defendants who confess to committing illegal activities and assist law enforcement authorities in prosecuting other agents may receive, in return for this cooperation, certain benefits. ${ }^{2}$ In the United States, the development of transactions and cooperative relationships between accused and public authorities has long since become a common feature of the state prosecution apparatus. ${ }^{3}$ In Continental tradition jurisdictions, where leniency policies have ordinarily been treated with high degrees of skepticism and mistrust, there are also clear signs of growing interest in the use of cooperating defendants in specific areas of law enforcement. ${ }^{4}$

Similar to other countries, Brazil has recently experienced a surge in the use of leniency policies. In 2000, an amendment to the former Brazilian

1 Different authors note this trend. See Nicholas Fyfe and James Sheptycki, 'International Trends in the Facilitation of Witness Co-Operation in Organized Crime Cases' (2006) 3 European Journal of Criminology 319, 339; Stephan Christoph, Der Kronzeuge Im Strafgesetzbuch: Die Ermittlungshilfe Gemäß \46b StGB Aus Dogmatischer Und Empirischer Perspektive (13th edn, Nomos 2019) 37-49; Florian Jeßberger, Kooperation Und Strafzumessung: Der Kronzeuge Im Deutschen Und Amerikanischen Strafrecht (Duncker \& Humblot GmbH 1999) 20-21; Francesco Centonze, 'PublicPrivate Partnerships and Agency Problems: The Use of Incentives in Strategies to Combat Corruption' in Springer International (ed), Preventing Corporate Corruption (Springer International Publishing 2014) 44.

2 Florian Jeßberger, 'Nulla Poena Quamvis in Culpa: Ammerkungen Zur Kronzeugenregelung in $\$ 46 \mathrm{StGB}$ ' in Christian Fahl and others (eds), Festschrift für Werner Beulke (C F Müller 2015) 1153.

3 See Michael Jaeger, Der Kronzeuge Unter Besonderer Berücksichtigung von $\$ 31$ BtMG (Peter Lang 1986) 266-281; Ian Weinstein, 'Regulating the Market for Snitches' (1999) 47 Buffalo Law Review 563, 564-565.

4 According to Peter Tak: "This figure, the crown witness, takes various names in foreign legal systems. In the Netherlands and in Germany it is called the 'kroongetuige' (NL) and 'Kronzeuge' (FRG), in Italy it was called 'pentito' and is now called 'collaboratore della giustizia'; in Great Britain he is known as 'supergrass', and in France such a witness is called 'repenti'." See Peter JP Tak, 'Deals with Criminals: Supergrasses, Crown Witnesses and Pentiti' (1997) 5 European Journal of Crime, Criminal Law and Criminal Justice 2, 2. 
Competition Act introduced the first Brazilian antitrust leniency program ("Programa de Leniência Antitruste"), which provided immunity from administrative penalties and criminal punishment for cartelists denouncing the conduct and cooperating in the prosecution of co-conspirators. In 2011, the enactment of the current Competition Act expanded and restructured the antitrust leniency program. In 2013, the Organized Crime Act came into force and established the rewarded collaboration regulation ("Colaboração Premiada"), which allowed cooperating defendants to obtain different benefits in exchange for providing assistance to law enforcement authorities. Also in 2013, the Clean Company Act authorized the granting of privileged treatment to companies that cooperate with public officials in the prosecution of corrupt practices. Last of all, in 2017 Brazilian lawmakers approved a statute permitting the Central Bank and the Securities and Exchange Commission to conclude leniency agreements with agents accused of practicing illegal transactions.

These legal mechanisms share a common feature: all of them engender a negotiation process with the objective of setting up an exchange in which defendants provide information and evidence to public officials and, in return, receive privileged treatment, normally in the form of full or partial immunity from applicable penalties. ${ }^{5}$ This negotiation process and the establishment of cooperative relationships between accused and enforcement authorities have raised several questions and caused perplexities in Brazilian law, demanding new solutions from courts and attracting substantial attention in legal scholarship.

The main subject of this thesis is the practice of the rewarded collaboration regulation, introduced by the 2013 Organized Crime Act. The thesis also analyzes, on a smaller scale, the Brazilian antitrust leniency program, provided for by the 2011 Competition Act. Among the leniency policies introduced recently in Brazilian law, the rewarded collaboration regulation and the antitrust leniency program are the only ones with a direct effect on criminal prosecution. The rewarded collaboration regulation allows cooperating defendants to obtain either full immunity from criminal

5 As noted by Ribeiro, Cordeiro and Guimarães: "It is clear that each type of leniency agreement incentivizes offenders to provide information to the authority - information that may be highly useful in order to uncover possible infringement crimes and prosecute other offenders. Thus, the underlying policy reason of such legal regimes is to deter infringements". See Diaulas Costa Ribeiro, Néfi Cordeiro and Denis Alves Guimarães, 'Interface between the Brazilian Antitrust, Anti-Corruption, and Criminal Organization Laws: The Leniency Agreements' (2016) 22 Law and Business Review of the Americas 195, 198. 
punishment or the reduction of criminal penalties. The antitrust leniency program, besides granting full or partial reduction of the administrative sanctions applicable to anti-competitive behavior, also provides immunity from criminal prosecution regarding crimes related to the practice of cartels. The other leniency policies don't establish any benefit for cooperating defendants in the field of criminal law, and their effects are limited to administrative sanctions.

In recent years, both the rewarded collaboration regulation and the antitrust leniency program have undergone significant growth and gained substantial importance in legal practice. ${ }^{6}$ Since the introduction of the antitrust leniency program, almost one hundred leniency agreements have been concluded, more than half of those after the enactment of the current Competition Act in 2011..$^{7}$ Due in large part to the antitrust leniency program, Brazil is nowadays internationally recognized as an important actor in the enforcement of anti-cartel policies. ${ }^{8}$

The practice implementation of the rewarded collaboration regulation has also rapidly accelerated since the enactment of the 2013 Organized Crime Act, with law enforcement authorities and cooperating defendants concluding hundreds of collaboration agreements thereafter. The use of collaboration agreements has mainly been developed in the enormous group of investigations dubbed "Operation Car Wash", which since 2014 has inquired intensively into corruption practices, bid rigging and money laundering concerning public procurement in Brazilian state companies. ${ }^{9}$

6 Noting this change, see Ana Frazao and Amanda Athayde, 'Leniência, Compliance e o Paradoxo Do Ovo Ou Da Galinha: Do Compliance Como Instrumento de Autorregulação Empresarial.' in Ana Frazao and Ricardo Villas Boas Cuevas (eds), Compliance Perspectivas e desafios dos programas de conformidade (Forum 2018) 297, 309-314.

7 Paulo Burnier and Victor Oliveira Fernandes, "The "Car Wash Operation" in Brazil and Its Challenges for Antitrust Bid Rigging Enforcement' in Paulo Burner da Silveira and William Evan Kovacic (eds), Global Competition Enforcement: New Players, New Challenges (Kluwer 2019) 128.

8 See OECD, Competition Law and Policy in Brazil - a Peer Review (OECD IDB 2010) 73; Ana Paula Martinez, 'Challenges Ahead of Leniency Programmes: The Brazilian Experience' (2015) 6 Journal of European Competition Law \& Practice 260, 261-262.

9 According to Eduardo Mello and Matias Spektor, the investigation "revolves around contractors bribing public officials in sums adding up to billions of U.S. dollars in order to secure construction and service contracts in the oil, nuclear, and public-infrastructure sectors-contracts that also became a device for siphoning money from state-run institutions into private pockets through overcharging." See 
The rapid growth in the use of collaboration agreements has resulted in important developments within the Brazilian criminal justice system.

Until recently, negotiations between public officials and defendants played a minor role in criminal investigations. In the traditional structure of Brazilian criminal procedure, parties have little freedom to dispose of criminal cases: defendants may not end the proceeding through confession of the facts and admission of guilt, while prosecutors are bound by the principle of compulsory prosecution and by several statutory rules limiting prosecutorial discretion. ${ }^{10}$ Furthermore, Brazilian courts are not passive observers of the parties' efforts to produce evidence and have the duty and the powers to guarantee an adequate factual inquiry, which limits the parties' capacity for developing consensual exchanges. The 1995 Small Claims Act authorized parties to resolve criminal proceedings through consensual transactions, but limited this possibility to investigations of petty crimes. Apart from these situations, the full-blown criminal proceeding remained the common reality in the investigation of medium and serious criminal behavior, in a context where the parties were not allowed to develop consensual exchanges within criminal proceedings.

The introduction of the rewarded collaboration regulation has modified this scenario, providing a legitimate negotiation forum in which accused and enforcement authorities can interact to achieve a common understanding that will decisively impact the investigation of grave crimes. The recurrent use of this forum to forge innovative collaboration agreements raised several questions regarding the role of consensual arrangements in Brazilian criminal justice. Which matters can be negotiated by the parties in a collaboration agreement? To what extent are these negotiations constrained by the limits set by statutory rules? What is the role of judicial bodies after the conclusion of an agreement? What are the effects of these agreements on other defendants?

Due to the swift development of the practice of rewarded collaboration regulation, the Brazilian judiciary has had to address these and other questions promptly. Unlike the experience of various other countries, where the assistance of cooperating defendants has often been used to investigate terrorism, drug trafficking and other forms of violent crimes, the Brazilian practice of collaboration agreements has occurred primarily in the investi-

Eduardo Mello and Matias Spektor, 'Brazil: The Costs of Multiparty Presidentialism' (2018) 29 Journal of Democracy 113, 113.

10 See section I.2. 
gation of white-collar criminality, ${ }^{11}$ in particular in the prosecution of corrupt acts and corporate wrongdoing. ${ }^{12}$ These investigations have led to the arrest and conviction of several high-ranking politicians and prominent businessmen, directly affected Brazil's economic and political elite, and left a permanent mark on the country's social landscape. ${ }^{13}$ In this context, the recent boom in the employment of collaboration agreements has drawn massive media coverage and become a frequent subject of legal disputes and debate by the Brazilian public. ${ }^{14}$ Because some of the conduct investi-

11 In Germany, the use of cooperating defendants has been developed initially in the prosecution of terrorism and drug traffic. See Matthias Breucker and Rainer OM Engberding, Die Kronzeugenregelung - Erfahrungen, Anwendungsfalle, Entwicklungen (Richard Boorberg Verlag 1999) 11-16; Winfried Hassemer, 'Kronzeugenregelung Bei Terroristischen Straftaten Thesen Zu Art. 3 Des Entwurfs Eines Gesetzes Zur Bekämpfung Des Terrorismus' (1986) 550 StrafVert. In Italy, it has been used largely in investigations of mafia groups. See Stefanie Mehrens, Die Kronzeugenregelung Als Instrument Zur Bekämpfung Organisierter Kriminalität: Ein Beitrag Zur Deutsch-Italienischen Strafprozessrechtsvergleichung (Iuscrim 2001) 173-179.

12 More recently, the investigation of corporate crimes and corruption practices has been a field of significant development of leniency policies in several countries. Defending this trend, see André Buzari, Kronzeugenregelungen in Straf- Und Kartellrecht Unter Besonderer Berücksichtigung Des $\mathbb{\$} 46 b$ StGB (Strafrecht in Forschung Und Praxis) (Dr Kovac 2015), 112-114; Stefanie Lejeune, 'Brauchen Wir Eine Kronzeugenregelung Zur Verfolgung von Korruptionsfällen?' in Transparency International (ed), Korruption in Deutschland: Strafverfolgung der Korruption Möglichkeinten und Grenzen (2004) 88. And also Dieter Dölling, 'Die Neuregelung Der Strafvorschriften Gegen Korruption’ (2000) 112 Zeitschrift für die gesamte Strafrechtswissenschaft 334, 354-355. Critically: Roland Hefendehl, 'Außerstrafrechtliche Und Strafrechtliche Instrumentarien Zur Eindämmung Der Wirtschaftskriminalität' (2007) 119 Zeitschrift für die gesamte Strafrechtswissenschaft 816, 846-847.

13 Regarding the widespread impact of the investigations, see Mariana Mota Prado and Lindsey Carson, 'Corruption Scandals, the Evolution of Anti-Corruption Institutions, and Their Impact on Brazil's Economy' in Edmund Amann, Carlos R Azzoni and Werner Baer Print (eds), The Oxford Handbook of the Brazilian Economy (Oxford University Press 2018) 753-754.

14 Noting the high publicity obtained by collaboration agreements in Brazil, Marcus Melo states that "Media coverage of the scandal hit citizens with an informational tsunami. The level of exposure of corrupt deals has probably no precedent in any democracy except for Italy during the Mani Pulite (Clean Hands) investigations of the early and mid-1990s." See Marcus André Melo, 'Crisis and Integrity in Brazil' (2016) 27 Journal of Democracy 50, 60. 
gated occurred abroad, the corruption inquiries spread to other jurisdictions and eventually gained international attention. ${ }^{15}$

The general reaction to the Brazilian rewarded collaboration regulation has been of a laudatory nature. ${ }^{16}$ Through collaboration agreements, law enforcement authorities achieved fast and remarkable results. Hundreds of defendants agreed to cooperate with the investigations, pay multi-million fines and serve prison sentences. Evidence and information provided by cooperators played a central role in the conviction of other accused and bolstered new inquiries. In view of the long-lasting problems of slowness and ineffectiveness in the prosecution of corporate crimes and corruption practices, ${ }^{17}$ collaboration agreements became an essential device for the successful prosecution of so-called "macro-delinquency". ${ }^{18}$ The results achieved in recent years indicate an apparent case of remarkable success in the reduction of impunity and the enhancement of deterrence. ${ }^{19}$

15 According to Marcos Tourinho: “(...) investigations have thus far involved 44 jurisdictions and agreements are simultaneously being negotiated (or have been reached) in several states, most notably the United States and Switzerland." Marcos Tourinho, 'Brazil in the Global Anticorruption Regime' (2018) 61 Revista Brasileira de Politica Internacional 1, 1-2.

16 See, e.g. Sabine Kurtenbach and Detlef Nolte asserting that the findings of Operation Car Wash were only possible because of collaboration agreements and that "While this procedure is not beyond criticism, it was the only viable strategy to identify the politicians and businesses involved in this extensive corruption network". Sabine Kurtenbach and Detlef Nolte, 'Latin America's Fight against Corruption: The End of Impunity' (2017) 3 GIGA Focus Latin America, 5.

17 The structural difficulties perceived in successful prosecution of these wrongdoings is well registered in literature: Michael Lindemann, 'Staatlich Organisierte Anonymität Als Ermittlungsmethode Bei Korruptions- Und Wirtschaftsdelikten' (2006) 39 Zeitschrift für Rechtspolitik 127, 127-130; Britta Bannenberg, Korruption in Deutschland Und Ihre Strafrechtliche Kontrolle (Hermann Luchterhand 2002), 64-65; Luís Greco and Alaor Leite, 'Die „Rezeption“ Der Tat- Und Organisationsherrschaft Im Brasilianischen Wirtschaftsstrafrecht' (2014) 6 ZIS Zeitschrift für Internationale Strafrechtdogmatik 285, 290.

18 Affirming the social relevance of the prosecution of these crimes, see Wolfgang Naucke, Der Begriff Der Politischen Wirtschaftsstraftat (LIT 2012), 85-91; Bernd Schünemann, 'Vom Unterschichts- Zum Oberschichtsstrafrecht: Ein Paradigmawechsel Im Moralischen Anspruch?' in Hans-Heiner Kühne and Koichi Miyazawa (eds), Alte Strafrechtsstrukturen und neue gesellschaftliche Herausforderungen in Japan und Deutschland (Duncker unb Humblot 2000) 15-36.

19 See Transparency International Secretariat, 'Brazil's Carwash task force wins Transparency International anti-corruption award' (Transparency International, 3 December 2016) <https://www.transparency.org/news/pressrelease/brazils_carw ash_task_force_wins_transparency_international_anti_corruption $>$ accessed 23 June 2019. 
The practice of the rewarded collaboration regulation received strong support from Brazilian public authorities, particularly the Federal Public Prosecution Office and the Federal Supreme Court. The Federal Public Prosecution Office has negotiated and concluded hundreds of agreements with cooperating defendants, designing ingenious solutions and developing consensual innovations that expanded the negotiation forum set by the Organized Crime Act. The Federal Supreme Court has adopted positions granting substantial freedom for cooperating defendants and law enforcement authorities to develop a flexible and broad system of negotiations. ${ }^{20}$ This support was largely grounded on the notion that collaboration agreements are part of a new model of consensual justice, which has a specific logic and works in a different manner to traditional Brazilian criminal procedure. ${ }^{21}$ Principles and doctrines normally associated with private contract law have gained great relevance as tools to interpret the rewarded collaboration regulation and resolve disputes regarding the use of collaboration agreements. In this context, several disputes regarding the correct use of collaboration agreements have been decided by courts based on the application of concepts such as the "res inter alios acta" principle, the "venire contra factum proprium" doctrine and the rule of "pacta sunt servanda".

The thesis develops a critical analysis of the practice of collaboration agreements and rejects core elements of the dominant view in Brazilian law regarding the rewarded collaboration regulation. This critical evaluation is based on two main arguments. First, it asserts that this understanding, which can be called a "contractualist approach" to the rewarded collaboration regulation, is irreconcilable with the structure of the Brazilian criminal justice system and jeopardizes fundamental guarantees of criminal procedure. Secondly, it asserts that the practice of collaboration agreements, as developed by legal actors in the last years, has serious - albeit unnoticed - side effects and leads to significant counter-productive results.

While rejecting the "contractualist approach" and refuting the notion that the rewarded collaboration regulation should be interpreted according to the principles of private contract law, the thesis offers an alternative perspective on the questions raised by the widespread use of collaboration agreements in criminal investigations. The thesis argues that collaboration agreements must be understood not as simple bilateral transactions between prosecutors and defendants, but rather as complex and durable public-private partnerships directed at establishing an evidentiary basis for the

20 See STF, HC 127483 [2015] and STF, PET 7074 [2017].

21 See item I.4.c. 
imposition of criminal punishment upon third parties. ${ }^{22}$ In this sense, the rewarded collaboration regulation entails a privatization process in the criminal law enforcement system, transferring to defendants functions that were previously performed by public officials. ${ }^{23}$ The understanding that these agreements represent a form of partial privatization of investigative and prosecutorial activities offers an interesting perspective to address the possibilities and risks arising from the large-scale deployment of the rewarded collaboration regulation. After elaborating this perspective, the thesis criticizes well-established concepts in Brazilian legal scholarship and case-law, analyzing consequences of the proposed approach on legal practice.

The critical appraisal proposed in the thesis has two cornerstones. In order to examine the association of the rewarded collaboration regulation with the ideal of consensual justice, the thesis analyzes the German experience with the practice of negotiated judgements ("Verständigung") in criminal cases and with the crown-witness regulation ("Kronzeugenregelung"). The assessment of these two legal mechanisms provides useful insights to comprehend the limits and contradictions of the Brazilian practice of collaboration agreements, especially in relation to the role of consensual arrangements within the process of fact-finding, determination of individual guilt and imposi criminal penalties. As a country of Continental tradition, Germany provides a noteworthy example of the questions and complexities that arise with the introduction of consensual mechanisms in a system where criminal process is understood as an official investigation carried

22 Regarding the formation of public-private partnerships in the enforcement system, see critically Hefendehl, 'Außerstrafrechtliche Und Strafrechtliche Instrumentarien Zur Eindämmung Der Wirtschaftskriminalität' (n 12) 846-847. For a descriptive view, see Centonze (n 1 ).

23 For a comprehensive view of the process of "privatization" in the Germany criminal procedure, see Hannah Stoffer, Wie Viel Privatisierung „verträgt" Das Strasfprozessuale Ermittlungsverfahren? (Mohr Siebeck 2016). Weigend notes a general trend of privatization of state functions and its impacts on the state's commitment to search for truth in criminal procedure See Thomas Weigend, 'Unverzichtbares Im Strafverfahrensrecht' (2001) 113 Zeitschrift für die gesamte Strafrechtswissenschaft 271,303. The risks of this process have also been noted in the realm of the so-called "internal investigations". See Luís Greco and Christian Caracas, 'Internal Investigations Und Selbstbelastungsfreiheit' (2015) 7 NStZ 1, 1-16; Adán Nieto Martín, 'Internal Investigations, Whistle-Blowing, and Cooperation: The Struggle for Information in the Criminal Process' in Stefano Manacorda, Francesco Centonze and Gabrio Forti (eds), Preventing Corporate Corruption (Springer 2014) 69-92. Examining the interconnections between corporate compliance programs and leniency policies, see Frazao and Athayde (n 6) 298-307. 
out by public authorities and aimed at correctly establishing the facts. ${ }^{24}$ In such an environment, basic pillars of criminal justice - like the state's commitment to search for truth and the principle of compulsory prosecution limit the parties' capacity to dispose of criminal cases and pose several obstacles to the negotiation of consensual exchanges within criminal proceedings. ${ }^{25}$ The question regarding the potential development of a consensual model of criminal justice in Germany has been a long and controversial topic of discussion, both in legal scholarship and in case-law. ${ }^{26}$ This debate has been especially significant in the field of economic crimes, in particular with the emergence of the so-called "monster proceedings" ("Monster-Verfahren"), complex investigations that can last several years and en-

24 The many differences between the U.S. party-driven justice system and the German model of official investigation have different impacts on the use of leniency policies in criminal investigations. See Jaeger (n 3) 266-281; Jeßberger, Kooperation und Strafzumessung (n 1) 159-163. They also affect the development of interparty negotiations regarding the confession of the accused. See Thomas Weigend, Absprachen in Ausländischen Strafverfahren: Eine Rechtsvergleichende Untersuchung $\mathrm{Zu}$ Konsensualen Elementen Im Strafprozess (Max-Planck-Inst für ausländisches und internat Strafrecht 1990); Dominik Brodowski, 'Die Verfassungsrechtliche Legitimation Des US-Amerikanischen „plea Bargaining“ - Lehren Für Verfahrensabsprachen Nach $\$ 257$ c StPO? (2013) 124 Zeitschrift für die gesamte Strafrechtswissenschaft 733.

25 Comparing the Anglo-American system of criminal procedure with the model traditionally adopted by continental European countries, Martin Heger highlights two main differences: "1) the working relationship between the judge and the other parties to the proceedings and 2) a vastly different expectation of the court's responsibility to ascertain the truth of a case". See Martin Heger, 'Adversarial and Inquisitorial Elements in the Criminal Justice Systems of European Countries as a Challenge for the Europeanization of the Criminal Procedure', in: BSU Law Faculty (ed.), Criminal proceeding based on the rule of law as the means to ensure human rights (Publishing Centre of BSU Minsk 2017) 199. See also Edda Weßlau, 'Wahrheit Und Legenden: Die Debatte Über Den Adversatorischen Strafprozess' (2014) 191 Zeitschrift für Internationale Strafrechtsdogmatik 558, 563-564; Bernd Schünemann, 'Zur Kritik Des Amerikanischen Strafprozessmodells' in Edda Wesslau and Wolfgang Wohlers (eds), Festschrift für Gerhard Fezer zum 70. Geburtstag am 29. Oktober 2008 (De Gruyter 2008) 557-560.

26 According to Luis Greco, the development of consensual arrangements in criminal procedure must be the most discussed subject in German criminal procedure literature in recent decades. See Luis Greco, "Fortgeleiteter Schmerz" Überlegungen Zum Verhältnis von Prozessabsprache, Wahrheitsermittlung Und Prozessstruktur' (2016) 1 Goltdammer's Archiv für Strafrecht 1, 1. 
counter enormous difficulties in the fact-finding process. ${ }^{27}$ Because of these different aspects, the German experience offers an interesting perspective for a critical analysis of the Brazilian practice of collaboration agreements and its purported association with a new system of consensual criminal justice. ${ }^{28}$

Secondly, the thesis draws on a growing body of literature that has emerged to provide a more thorough review of the effects of leniency policies. ${ }^{29}$ The widespread dissemination of leniency policies in the last decades and the much-vaunted results obtained by enforcement agencies have led several authors to speak of a "leniency revolution". ${ }^{30}$ Highlighting the palpable outcomes achieved with the use of cooperating defendants,

27 Bernd Schünemann, 'Die Verständigung Im Strafprozeß - Wunderwaffe Oder Bankrotterklärung Der Verteidigung?' [1989] Neue Juristische Wochenschrift $1895,1898$.

28 Because of its unique features, the German experience with the introduction of consensual mechanisms in criminal justice has already gained vast attention in comparative scholarship. See Thomas Swenson, "The German "Plea Bargaining" Debate' (1995) 7 Pace International Law Review 373; Markus Dirk Dubber, 'American Plea Bargains, German Lay Judges, and the Crisis of Criminal Procedure' (1997) 49 Stanford Law Review 547; Máximo Langer, 'From Legal Transplants to Legal Translations: The Globalization of Plea Bargaining and the Americanization Thesis in Criminal Procedure' (2004) 45 Harvard International Law Journal 1; Stephen C Thaman, 'Plea-Bargaining, Negotiating Confessions and Consensual Resolution of Criminal Cases' in Katharina Boele-Woelki \& Sjef van Erp (eds), General Reports of the XVIITH Congress of the International Academy of Comparative Law (Bruylant/ Eleven 2007).

29 This has occurred mainly in the field of anti-cartel enforcement. See the seminal paper by Motta and Polo: Massimo Motta and Michele Polo, 'Leniency Programs and Cartel Prosecution' (2003) 21 International Journal of Industrial Organization 347. After that, several studies have attempted to test different aspects of leniency policies in the prosecution of cartels, corruption and organized crime. See, e.g. Cécile Aubert, Patrick Rey and William E Kovacic, 'The Impact of Leniency and Whistle-Blowing Programs on Cartels' (2006) 24 International Journal of Industrial Organization 1241; Paolo Buccirossi and Giancarlo Spagnolo, 'Leniency Policies and Illegal Transactions' (2006) 90 Journal of Public Economics 1281, 1296; Joseph E Harrington Jr., 'Optimal Corporate Leniency Programs' (2008) 56 The Journal of Industrial Economics 215; Antonio Acconcia and others, 'Accomplice Witnesses and Organized Crime: Theory and Evidence from Italy' (2014) 116 Scandinavian Journal of Economics 1116.

30 As noted by Giancarlo Spagnolo: "The last ten years have witnessed what one could call, with little or no exaggeration, a revolution in competition policy and antitrust enforcement, "the leniency revolution." See Giancarlo Spagnolo, 'Leniency and Whistleblowers in Antitrust' in Paolo Buccirossi (ed), Handbook of Antitrust Economics (The MIT Press 2008) 259. 
such as the growing number of investigations opened, the increase in penalties imposed and the boost in fines collected, the discourse of public authorities portrays leniency policies as a crucial tool in the prosecution of sophisticated criminal organizations and powerful offenders. ${ }^{31}$ More recently, a substantial number of economic studies have arisen examining and testing the effects of leniency policies, pointing out various risks and side-effects, such as the excessive reduction of penalties, the distortion of incentives for enforcement agencies and the possibilities of reverse exploitation of the leniency system. ${ }^{32}$ This body of economic research suggests that the traditional approach of enforcement agencies to leniency policies is reductionist and uncritical, largely ignoring the hazards and tradeoffs involved..$^{33}$ Because the legitimacy of the Brazilian practice of collaboration agreements stems largely from the results achieved, this body of literature offers a valuable perspective for a critical analysis.

The thesis proceeds as follows. Chapter I presents the development and structure of the rewarded collaboration regulation, introduced by the 2013 Organized Crime Act, and the antitrust leniency program, as provided in the 2011 Competition Act, describing the central subject of analysis: the inventive use of collaboration agreements, as developed in Brazilian legal practice. Chapter II examines the types of investigations in which the Brazilian practice of collaboration agreements was developed, and describes its impacts on the prosecution of corruption networks and macrodelinquency. Chapter III discusses the rationale, expectations and risks associated with leniency policies, particularly in the field of white-collar

31 For such a view regarding the U.S. antitrust leniency program, see Ann O'Brien, 'Leadership of Leniency' in Caron Beaton-Wells and Christopher Tran (eds), Anti-cartel enforcement in a contemporary age: leniency policies (Hart Publishing 2015); Scott D Hammond, 'Cornerstones of an Effective Cartel Leniency Programme' (2008) 4 Competition Law International 4. For a similar approach regarding the Brazilian experience with collaboration agreements, see Sérgio Fernando Moro, 'Preventing Systemic Corruption in Brazil' (2018) 147 Daedalus 157; Rodrigo Janot, 'The Lessons of Car Wash' Americas Quarterly (New York, 12 January 2018) $<$ https://www.americasquarterly.org/content/lessons-car-wash $>$ accessed 10 July 2018.

32 For a good overview of this body of literature, see Catarina Marvão and Giancarlo Spagnolo, 'What Do We Know about the Effectiveness of Leniency Policies? A Survey of the Empirical and Experimental Evidence' in Caron Beaton-Wells and Christopher Tran (eds), Anti-cartel enforcement in a contemporary age: leniency policies (Hart Publishing 2015).

33 See Caron Y Beaton-Wells, 'Immunity for Cartel Conduct: Revolution or Religion? An Australian Case Study' (2014) 2 Journal of Antitrust Enforcement 126. 
criminality, reviewing the body of literature that has recently emerged testing the effects of these mechanisms. Chapter IV examines the German experience with the practice of negotiated criminal judgements and with the crown-witness regulation, establishing points of analysis that are useful to assess the Brazilian practice of collaboration agreements. From the concepts discussed and the results achieved in Chapters III and IV, Chapter $\mathrm{V}$ carries out a critical appraisal of the Brazilian practice of collaboration agreements and presents an alternative perspective on the rewarded collaboration regulation in Brazilian law. Chapter VI exposes important legal consequences of the positions defended in Chapter V. 


\section{Chapter I - The development of leniency policies in Brazilian criminal justice and the contractualist approach to collaboration agreements}

\section{Introduction}

Until recently, negotiations between public authorities and defendants played a minor role in the Brazilian system of criminal justice, basically serving to provide a swift resolution for the investigation of minor offenses. ${ }^{34}$ The recent growth of leniency policies in Brazilian law, especially after the introduction of the rewarded collaboration regulation by the 2013 Organized Crime Act, has changed this scenario, decisively boosting the use of consensual arrangements in criminal proceedings, particularly in the investigation of corrupt practices and corporate wrongdoing. ${ }^{35} \mathrm{~A}$ distinctive mark of this development has been the detachment between the textual provisions of the Organized Crime Act and the collaboration agreements negotiated in the judicial practice by procedural participants, which have designed innovative solutions and inventive arrangements, expanding the negotiation forum well beyond the statutory limits. ${ }^{36}$

34 The Brazilian Code of Criminal Procedure does not contain rules authorizing the resolution of cases through consensual arrangements. The first possibilities of inter-party negotiations were introduced by the 1995 Small Claims Act, but had its use restricted to the investigation of minor offenses. On this issue, see section I.2.

35 According to Fabiano Silveira: "It is from 2013 onwards that the model of negotiated justice will take a heavy toll on the Brazilian tradition of criminal procedure”. See Fabiano Augusto Martins Silveira, 'O Papel Do Juiz Na Homologação Do Acordo de Colaboração Premiada' (2018) 17 Revistas de Estudos Criminais 107,114 . As noted by Daniel Sarmento, this development has occurred mainly in investigations of white-collar crimes, often involving high-ranking politicians and businessmen. See Daniel Sarmento, 'Colaboração Premiada. Competência Do Relator Para Homologação e Limites à Sua Revisão Judicial Posterior. Proteção à Confiança, Princípio Acusatório e Proporcionalidade', Direitos, democracia $e$ República: escritos de direito constitucional (Fórum 2018) 452. On the connection between the practice of collaboration agreements and the investigation of Brazilian macro-delinquency, see items II.2 and II.4.

36 Multiple authors have extensively registered this detachment. See Andrey Borges de Mendonça, 'Os Benefícios Possíveis Na Colaboração Premiada: Entre a Legalidade e a Autonomia Da Vontade' in Maria Thereza de Assis Moura and Pierpaolo 
Because of the innovative nature of the Brazilian practice of collaboration agreements, a correct assessment of the rewarded collaboration regulation can only be carried out with attention to the "law in action". 37 This chapter depicts the central features of the inventive practice of collaboration agreements and the solid support this practice has received from the Brazilian judiciary, especially from the Brazilian Federal Supreme Court. ${ }^{38}$

Cruz Bottini (eds), Colaboração premiada (Revista dos Tribunais 2017) 77-101; Salo de Carvalho, 'Colaboração Premiada e Aplicação Da Pena: Garantias e Incertezas Dos Acordos Realizados Na Operação Lava Jato' in Américo Bedê Júnior and Gabriel Silveira de Queirós Campos (eds), Sentenca criminal e aplicação da pena: ensaios sobre discricionariedade, individualização e proporcionalidade (Juspodivm 2017) 516; Thiago Bottino, 'Colaboração Premiada E Incentivos À Cooperação No Processo Penal : Uma Análise Crítica Dos Acordos Firmados Na "Operação Lava Jato " (2016) 122 Revista Brasileira de Ciências Criminais 359; Marcelo Costenaro Cavali, 'Duas Faces Da Colaboração Premiada: Visões "Conservadora” e "Arrojada” Do Instituto Na Lei 12.850/2013' in Maria Thereza de Assis Moura and Pierpaolo Cruz Bottini (eds), Colaboração premiada (Revista dos Tribunais 2017); Vinícius Gomes de Vasconcellos, Colaboração Premiada No Processo Penal (Revista dos Tribunais 2018) 17; JJ Gomes Canotilho and Nuno Brandão, 'Colaboração Premiada e Auxílio Judiciário Em Matéria Penal: A Ordem Pública Como Obstáculo à Cooperação Com a Operação Lava Jato' (2016) 146 Revista de Legislação e Jurisprudência 16, 31-35.

37 Martin Heger and Robert Pest note that the detachment between statutory provisions and legal practice has also been a central characteristic of the German experience with negotiated criminal judgments. See Martin Heger and Robert Pest, 'Verständigungen Im Strafverfahren Nach Dem Urteil Des Bundesverfassungsgerichts' (2014) 126 Zeitschrift für die gesamte Strafrechtswissenschaft 446, 468. In the same vein: Thomas Weigend, 'Neues Zur Verständigung Im Deutschen Strafverfahren?' in Leblois-Happe, Jocelyne/Stuckenberg and Carl-Friedrich (eds), Was wird aus der Hauptverhandlung? Quel avenir pour l'audience de jugement? (Boon University Press 2014) 208. For a more thorough exam of the development and regulation of these negotiations in German criminal procedure, see item IV.2.b and IV.2.d.

38 In Germany, various studies have attempted to capture the characteristics of the practice of informal negotiations developed by procedural participants before courts. For one of the first attempts, see Bernd Schünemann, 'Gutachten, Kongressvortrag, Aufsatz | Absprachen Im Strafverfahren - Grundlagen, Gegenstande Und Grenzen' (1990) Deutscher Juristentag 58 b12. Recently, an empirical study conducted in 2012 showed a strong dissociation between legal practice and legal regulation, indicating a pattern of widespread disregard for the statutory rules. See Karsten Altenhain, Frank Dietmeier and Markus May, Die Praxis Der Absprachen in Strafverfahren (120th edn, Nomos 2013). The study and its findings had a major impact on the 2013 ruling of the German Federal Constitutional Court on the constitutionality of the regulation of negotiated criminal judgments. On this issue, see item IV.2.e. 
Therefore, its main focus is the analysis of the consensual innovations engendered by legal practitioners in agreements concluded over recent years, as well as the judicial decisions that validated these agreements. ${ }^{39}$

The chapter proceeds as follows. Section I.2 gives a brief overview of the Brazilian procedural system, indicates the traditional limits for the development of inter-party negotiations in criminal procedure and describes the development of the two leniency policies in Brazilian law that affect directly criminal investigations: the rewarded collaboration regulation and the antitrust leniency program. Item I.2.a describes the introduction of the first antitrust leniency program in 2000, the changes brought in 2011 by the enactment of the current Competition Act and the strong expansion of the program afterwards. Item I.2.b describes the Brazilian experience with the granting of benefits to cooperating defendants in criminal investigations up to the introduction of the rewarded collaboration regulation by the 2013 Organized Crime Act. It also depicts the boom in the use of collaboration agreements since 2014, especially in the prosecution of corporate crimes and corrupt practices.

Section I.3 portrays the central aspects of the legislative regulation of the two leniency policies. Item I.3.a analyzes the dynamics of negotiation established in both regulations, based on informal communication between the parties and directed at the conclusion of a written agreement. Item I.3.b examines the terms of negotiation between public authorities and cooperating defendants, describing the attainable benefits for cooperators provided by the Competition Act and in the Organized Crime Act as well as the associated duties regarding the assistance of official investigations. Item I.3.c analyzes the separation between the moment of signing of the written agreement and the moment of assessment of its fulfilment, highlighting the division of function between public authorities involved in the development of leniency policies.

Section I.4 addresses the central point of the chapter: the development in Brazilian legal practice of an innovative system of negotiating collaboration agreements, which has engendered an unambiguous detachment between the provisions of the Organized Crime Act and the "law in action".

39 Other studies have already focused their analysis on the innovations brought by the Brazilian practice of collaboration agreements, but usually from a small sample of specific cases. Canotilho and Brandao assessed various clauses of two collaboration agreements concluded in 2014. See Canotilho and Brandão (n 36). Bottino analyzed these two agreements and also a third one. See Bottino (n 36). Vinicius Vasconcellos examined a total of five agreements. See Vasconcellos, Colaboração Premiada No Processo Penal (n 36). 
Item I.4.a analyzes four central innovations created by the Brazilian practice of the rewarded collaboration regulation: (i) the granting of benefits not provided by the Organized Crime Act; (ii) the exact definition of imprisonment penalties through consensual arrangements; (iii) the development of 'package deals'; (iv) the development of provisions for cooperating defendants to serve imprisonment penalties in advance, at early stages of the criminal proceeding. Item I.4.b describes the environment of broad contractual freedom and the model of tailor-made arrangements developed by legal practitioners. Item I.4.c examines the support of public authorities - prosecutors and courts - to the development of a broad and flexible system of negotiation of collaboration agreements and its correlation to the ideal of a new model of consensual criminal justice. It also depicts two central points in Brazilian case-law regarding the practice of the rewarded collaboration regulation: the understanding that collaboration agreements have a binding effect upon judicial decisions (I.4.b.i) and the position that these agreements create obligations and rights only for the contracting parties and do not affect the other accused (I.4.b.ii).

\section{The Brazilian procedural tradition and the recent development of leniency policies}

Brazilian criminal procedure is traditionally structured as an official investigation to ascertain criminal conduct and identify its perpetrators, conferring little space for procedural participants to dispose of criminal cases through consensual arrangements. ${ }^{40}$ The Code of Criminal Procedure does

40 Describing this structure of Brazilian criminal procedure, Marcelo Cavali states: "The natural path for the definition of criminal liability, in our system, starts with the ascertainment of the occurrence of a crime and of its perpetrator through a formal investigation; subsequently, once the perpetrators are identified, an indictment must be elaborated, exposing the criminal facts and all their circumstances, assigning them a certain legal qualification and requiring, as an automatic consequence, the imposition of the applicable penalties (...)". See Cavali (n 36) 258. In the same vein, Fabiano Silveira notes that the traditional model of Brazilian criminal justice is structured as an official inquiry to ascertain the truth, and leaves little room for negotiation between procedural parties. See Silveira (n 35) 109-110. Langer notes that the traditional backbone of several Latin America countries, including Brazil, consists of a written dossier assembling documentary evidence and compiled by investigate authorities, limiting the possibilities for the parties to resolve the case without going to trial. See Langer (n 28) 621, 629-631. 
not establish any option for inter-party transactions, and the first possibilities for the consensual resolution of criminal cases were introduced by the 1995 Small Claims Act. ${ }^{41}$ Unlike jurisdictions where parties of a criminal proceeding are largely free to forge various types of transactions, ${ }^{42}$ public prosecutors and defendants in Brazil face several structural restrictions on their capacity to settle criminal cases through consensual arrangements. ${ }^{43}$

A key restriction arises from the principle of compulsory prosecution, which determines that the Public Prosecution Office must press charges whenever the statutory thresholds are fulfilled. ${ }^{44}$ Based on this principle, the Brazilian Code of Criminal Procedure entails several rules limiting prosecutorial discretion regarding the opening, conduction and withdrawal of a criminal process and enables judicial control of prosecutorial acts at different phases of the proceeding. Although the Public Prosecution Office

41 According to Alexandre Wünderlich, the 1995 Small Claims Acts introduced "the first model of negotiated criminal justice in the country". See Alexandre Wunderlich, 'Colaboração Premiada: O Direito à Impugnação de Cláusulas e Decisões Judiciais Atinentes Aos Acordos' in Maria Thereza de Assis Moura and Pierpaolo Cruz Bottini (eds), Colaboração premiada (Revista dos Tribunais 2017) 20. Similarly, Vladimir Aras asserts that the 1995 Small Claims Acts "introduced a new paradigm in the national legal order: consensual criminal justice". See Vladimir Aras, 'Acordos Penais No Brasil: Uma Análise à Luz Do Direito Comparado' in Rodrigo Leite Ferreira et al Cabral (ed), Acordo de não persecução penal-Resolução 181/2017 do CNMP com as alterações feitas pela Res. 183/2018 (Juspodivm 2019) 268.

42 The most analyzed example is, of course, the U.S. system of criminal justice and its well-known model of plea bargaining. For a historical description, see Albert W Alschuler, 'Plea Bargaining and Its History' (1979) 13 Law \& Society Review 211.

43 Despite these restrictions, Vinicius de Vasconcellos notes critically a trend, in the last two decades, towards the expansion of scope for negotiation in Brazilian criminal justice. See Vinícius Gomes de Vasconcelos, Barganha e Justiça Criminal Negocial: Análise Das Tendências de Expansão Dos Espaços de Consenso No Processo Penal Brasileiro (Editora IBCCRIM 2014) 97-142. Noting the same trend, but with a favourable view: Jamil Chain Alves, 'Justiça Consensual e "Plea Bargaining"' in Rodrigo Leite Ferreira et al Cabral (ed), Acordo de não persecução penal-Resolução 181/2017 do CNMP com as alteraçôes feitas pela Res. 183/2018 (Juspodivm 2019) 194-200.

44 According to Eugenio Pacelli, the Brazilian legislation opted for the "adoption of the principle of compulsory prosecution or legality, according to which the Public Prosecution Office must act guided by objectivity (criteria defined by statute)". See Eugênio Pacelli, Curso de Processo Penal, vol 53 (Atlas 2013) 13-14. Aury Lopes Jr. asserts that this implies that prosecutors may not dispose of cases according to their discretion and must observe the statutory requirements. See Aury Lopes Jr., Direito Processual Penal (Saraiva 2019) 202-203. 
has a monopoly regarding the decision to press criminal charges, this decision must respect the legal requirements, and prosecutors may not freely choose whether or not to present charges against criminal suspects. ${ }^{45}$ According to the Code of Criminal Procedure, courts can question the decision of a prosecutor to close a criminal investigation without pressing charges. ${ }^{46}$ Furthermore, the Public Prosecution Office may not drop criminal charges or appeals after they have been filed. ${ }^{47}$ A prosecutorial motion for the defendant's acquittal does not end the process, and courts, faced with such a motion, may convict the accused and even identify aggravating circumstances that were not alleged by the prosecutor. ${ }^{48}$

Another important constraint arises from the state's commitment to adequate process of fact-finding, which prevents defendants from terminating a criminal proceeding through a confession or an admission of guilt. ${ }^{49}$ The Code of Criminal Procedure establishes that the defendant's confession does not interrupt the official investigation, and the gathering of evidence must continue even when the accused has admitted to committing the investigated acts. ${ }^{50} \mathrm{~A}$ confession is insufficient to substantiate a conviction, representing an element that must be analyzed under the same criteria used to examine the other pieces of evidence. ${ }^{51}$ The accused may with-

45 In a relevant ruling, the Brazilian Federal Supreme Court affirmed that, in Brazilian criminal procedure, "compulsory prosecution is the rule; the prosecutor is constrained to present charges, whenever there exist legal and factual grounds for the indictment". The ruling recognized, however, that the principle could be somewhat loosened in the circumstances established by the Small Claims Act. See STF, HC 75343 [1997].

46 Brazilian Code of Criminal Procedure, art 28. According to the provision, if a court does not accept the prosecutor's decision to close the investigation without pressing charges, the case must be analyzed by the Prosecutor General. If the decision to close the investigation is upheld, the court must then accept it.

47 Brazilian Code of Criminal Procedure, arts 42 and 576. Regarding this point, the Brazilian Federal Supreme Court recently decided that "once presented the criminal charge or lodged an appeal, the accusation may not withdraw its claim." See STF, AP 921 [2017] (Fux J).

48 Brazilian Code of Criminal Procedure, art 385. Asserting that the Public Prosecution Office may not dispose of the criminal proceeding, the Federal Supreme Court decided that the final arguments presented by a prosecutor "are mere allegations, preparatory acts, oriented to convince the court, without, however, delimiting the scope of the judicial assessment or the direction of the verdict." See STF, AP 1006 [2018].

49 Brazilian Code of Criminal Procedure, art 197.

50 ibid art 158

51 ibid art 197. 
draw the confession at any time, and courts are free to examine its reliability, taking into consideration the entire body of evidence..$^{52}$ Furthermore, parties cannot freely dispose of the gathering of evidence and the factual inquiry, since courts also have powers to determine the production of evidence and the hearing of witnesses that were not requested by the parties. ${ }^{53}$

In this context, the standard model of Brazilian criminal procedure provides little room for the parties to dispose of criminal cases thorough mutual understandings. As in other continental tradition countries, Brazil's criminal procedure is traditionally structured as an official investigation carried out by state authorities with the objective of impartially determining the circumstances of criminal conduct, ascertaining the criminal liability of the responsible individuals and imposing the applicable legal consequences.$^{54}$ Throughout the whole process, courts have a central function in carrying out the official investigation, acting not only as a passive referee, but also taking measures to ensure an accurate and reliable reconstruction of the investigated conduct. ${ }^{55}$

In a system marked by rules of compulsory prosecution, by the limited value of a defendant's confession and by the central role of courts in the process of fact-finding and assessment of criminal liability, prosecutors and defendants had - until the end of the twentieth century - no space to develop legitimate negotiations and alter the normal course of a criminal proceeding. The introduction of the first possibilities for consensual interparty arrangements arose when the 1995 Small Claims Act was enacted, establishing two mechanisms for consensual solutions in Brazilian criminal procedure.

52 ibid art 200.

53 ibid art 156 II and art 209.

54 Langer compares jurisdictions that conceive criminal procedure as an official investigation, particularly in countries in Latin America and continental Europe, with others that envisage it as a dispute between two parties, most notably the United States. See Langer (n 28) 17-26. Noting the similarities of Brazilian criminal procedure with traditional pillars of continental criminal justice, see Canotilho and Brandão (n 36) 22. For a good description of traditional Brazilian criminal procedure as a system of official investigation, see Cavali (n 36) 258; Silveira (n 35) 109-110.

55 On the differences regarding the role played by judicial bodies in the AngloAmerican and in the continental systems of criminal justice, see Heger, 'Adversarial and Inquisitorial Elements in the Criminal Justice Systems of European Countries as a Challenge for the Europeanization of the Criminal Procedure' (n 25). 
The main consensual mechanism introduced by the 1995 Small Claims Act was the 'criminal transaction', through which the Public Prosecution Office may, in the investigation of crimes punishable with a maximum of two years' imprisonment, offer the direct imposition of penalties of restriction of rights or monetary fines. ${ }^{56}$ Should the defendant accept the offer, the court can impose the negotiated penalty without further inquiry into the investigated facts. ${ }^{57}$ The 1995 Small Claims Act also authorizes the Public Prosecution Office, in the investigation of crimes in which the minimum penalty is one year or less, to request the suspension of the proceeding. ${ }^{58}$ If the accused agrees with the request, the court may establish conditions - such as the duty to compensate the caused damages, the prohibition of visiting specific locations and leaving their district without judicial authorization, and compulsory appearance before the court every month for the the proceeding's suspension. ${ }^{59}$

The 1995 Small Claims Act introduced the first possibilities for consensual solutions in Brazilian criminal producing, but at the same time imposed several limits on the use of these mechanisms. Besides the restricted applicability regarding the gravity of the offenses, the consensual solutions designed by the Small Claims Act do not allow for the imposition of imprisonment penalties, but only sanctions the restriction of rights, the imposition of fines and damage compensation. The effects of these solutions are limited to the imposition of the negotiated penalties and are not equivalent to the legal consequences of a judicial verdict on the defendant's guilt. ${ }^{60}$ They do not affect the defendant's criminal record and his status regarding the issue of recidivism. ${ }^{61}$ Unlike a judicial conviction, they do not establish civil liability of the accused in relation to the damages caused by the crime. ${ }^{62}$

56 Brazilian Small Claims Act 1995, art 76.

57 ibid art $76 \$ 3-4$.

58 ibid art 89.

59 ibid art $89, \mathbb{} 1$.

60 The Brazilian Federal Supreme Court drew a clear distinction between the effects of consensual solutions established in the Small Claims Act and judicial convictions achieved through regular proceedings. According to the Court, the determination of wrongful conduct and the establishment of the defendant's guilt depend on a judicial verdict and sentence, which cannot be achieved through a transaction and may only be delivered after the completion of the regular criminal proceeding. See STF, RE 795567 [2015].

61 Brazilian Small Claims Act 1995, art 76 \$5-6.

62 ibid art $76 \$ 6$. 
Under these conditions, the impacts of the 1995 Small Claims Act were narrow and full-blown proceedings remained the normal reality in Brazilian criminal justice. The restricted value of an accused's confession, the rules related to the principle of compulsory prosecution and the central role of judicial bodies in the fact-finding process restricted the formation of a wider system of inter-party negotiations within Brazilian criminal procedure. While in investigations of minor offenses, defendants and prosecutors could use the limited negotiation forum designed by the 1995 Small Claims Act, in investigations of medium or grave crimes there was simply no space for the development of inter-party consensual arrangements.

\section{a. Competition law}

The antitrust leniency program was first introduced in Brazilian law in 2000, through the amendment of the former Brazilian Competition Act, and established the possibility for participants in cartels - both individuals and companies - to obtain certain benefits, should they provide effective assistance in the prosecution of former co-conspirators. ${ }^{63}$ In general terms, the program enabled firms and individuals involved in cartels to obtain immunity from administrative sanctions or, at least, reductions in the penalties established by the former Brazilian Competition Act. ${ }^{64}$ For individuals, the antitrust leniency program also granted immunity from criminal prosecution for offenses provided by the 1990 Economic and Tax Crimes Act. ${ }^{65}$

According to the rules approved in 2000 , in order to obtain the leniency benefits, the agent had to cease the illegal conduct and fully cooperate with the investigation, providing useful information for the prosecution of

63 The antitrust leniency program was introduced into the 1994 Brazilian Competition Act through a legislative amendment occurred in 2000. See Law 10149 [2000], art 2.

64 Law 8884 [1994], art 35-b. According to the OECD, the disposition allowed the Brazilian competition authority "to enter into leniency agreements under which individuals and corporations, in return for their cooperation in prosecuting a case, are excused from some or all of the penalties for unlawful conduct under Law 8884". See OECD, Brazil - Peer Review of Competition Law and Policy (OECD IDB 2005) 51.

65 ibid art 35-c. "The leniency provision is supplemented by new Article 35-C, which provides that successful fulfilment of a leniency agreement will also protect cooperating parties from criminal prosecution under Brazil's economic crimes law (Law 8137/90)" (ibid., 51). 
other cartel members. ${ }^{66}$ In each case, this cooperative relationship had to be established in an agreement between offenders and the Brazilian competition authorities, which would be formalized through a written document. ${ }^{67}$

The introduction of the antitrust leniency program in Brazilian law was strongly influenced by foreign legal practices. According to the legislative proposal, leniency policies were already being successfully used in the prosecution of cartels in the United States, Canada, the United Kingdom and the European Union. ${ }^{68}$ The parliamentary debates also stressed the effectiveness of the leniency program in the United States, asserting that the number of cartels uncovered had increased fivefold since its introduction. ${ }^{69}$ A previous study by the Organization for Economic Co-operation and Development (OECD) had already suggested the amendment of the former Brazilian Competition Act in order to introduce a leniency program. ${ }^{70}$ Following the United States' example, ${ }^{71}$ the antitrust leniency program introduced in 2000 adopted a "winner-takes-all" model, ${ }^{72}$ in which the benefits are granted only to the first individual or company to cooperate with law enforcement authorities, and other agents involved in the

66 ibid art 35-b para I-II.

67 ibid art $35-\mathrm{b} \mathbb{3} 3^{\circ}$.

68 On this point, the explanatory notes of the proposal stressed: "In the case of the United States, the adoption of an amnesty program, similar to the one which is now proposed, has enabled an increase without precedents in the detection of cartels, including international cartels." See Senado Federal, 'Diário do Congresso Nacional' (35, 10 October 2000) 22276.

69 As noted in the legislative report that approved the bill. See Senado Federal, 'Diário do Congresso Nacional' (42, 15 October 2000) 28120.

70 In 2000, an OECD study affirmed the need for an increase in the investigative powers of the Brazilian antitrust authorities, to enable more effective prosecution of cartels. See OECD, 'Competition Law and Policy Developments in Brazil' (2000) 2 OECD Journal of Competition Law and Policy 1, 207. According to the 2005 OECD Peer Review on Brazil, "most of the recommendations in the 2000 Report to which it could respond have been accomplished, including particularly the recommendations relating to increased efficiency in merger reviews and reallocation of resources to cartel enforcement”. See OECD, Brazil - Peer Review of Competition Law and Policy (n 64).

71 Several authors point out the influence of the success of the U.S. leniency program on the introduction of antitrust leniency in Brazil. In this regard, see Gary R Spratling, 'Detection and Deterrence: Rewarding Informants for Reporting Violations' (2001) 69 George Washington Law Review 798, 800; Jason D Medinger, 'Antitrust Leniency Programs: A Call for Increased Harmonization as Proliferating Programs Undermine Deterrence' (2003) 52 Emory Law Journal 1439, 1440.

72 Martinez (n 8) 261. 
same conduct cannot apply for leniency afterwards. ${ }^{73}$ Also following the U.S. model, the program also prevented ringleaders from applying for antitrust leniency. ${ }^{74}$

In 2011, the current Competition Act came into force, restructuring several aspects of the Brazilian competition law. Once again, the legislative changes were mainly based on international experiences and followed, to a large extent, the recommendations of two OECD Reports, from $2005^{75}$ and $2010 .{ }^{76}$ Although the basic structure of the leniency program introduced in 2000 remained the same, including the "winner-takes-all" model, the 2011 reform made significant modifications. The new legislation revoked the provision that excluded ringleaders from the leniency pro$\operatorname{gram} .{ }^{77}$

Another important change amplified the immunity from criminal prosecution granted by the antitrust leniency program. In the original program introduced in 2000, this immunity was restricted to "crimes against the economic order"78 and it was possible for beneficiaries of the antitrust leniency to be held criminally liable for conduct connected to the antitrust offense. ${ }^{79}$ The current antitrust leniency provisions establish that the agreement covers not only crimes against the economic order but also "other crimes directly related to the practice of cartel." 80 They also expressly provide immunity for some crimes established by the Criminal Code, such as the crime of a being member of a "criminal association", and crimes under the Public Procurement Act, such as bid rigging. ${ }^{81}$

73 For a discussion regarding these models, see OECD, 'Leniency for Subsequent Applicants' (OECD 2012).

74 According to the explanatory notes of the proposal that introduced the antitrust leniency program, this rule was necessary to prevent offenders from "benefiting from their own villainy." See Senado Federal, 'Diário do Congresso Nacional' (35, 10 October 2000) 22276.

75 OECD, Brazil - Peer Review of Competition Law and Policy (n 64).

76 OECD, Competition Law and Policy in Brazil - a Peer Review (n 8).

77 The rules introduced in 2000 provided that the antitrust leniency program "does not apply to companies or individuals who have been at the forefront of the conduct", while the current 2011 Competition Act does not impose any similar restriction.

78 See Law 8884 [1994], art 35-C.

79 At the time, the limited immunity from criminal prosecution was identified as one of the biggest obstacles to the effectiveness of the Brazilian antitrust leniency program.

80 Brazilian Competition Act 2011, art 87.

81 Explaining the effects on criminal prosecution of the current Brazilian antitrust leniency program, Luz and Spagnolos assert: "In Brazil, cartels are both an ad- 
Since its introduction, in 2000, the Brazilian antitrust leniency program has evolved significantly and gained prominence, both domestically and abroad. ${ }^{82}$ Nowadays, Brazil is internationally recognized as a significant player in field of anti-cartel enforcement ${ }^{83}$ and its leniency program plays an important role in the prosecution of global cartels. ${ }^{84}$ Regarding the practical use of the mechanism, the approval in 2011 of the current Competition Act represented a milestone in the development of antitrust leniency in Brazil. ${ }^{85}$

An important development which has occurred recently is the strengthening of the relationship between the antitrust leniency program and criminal prosecution of high-profile cases. In recent years, the program has played an important role in the discovery and prosecution of business cartels in public procurements that were intertwined with corruption

ministrative offense and a crime, punishable by a criminal fine and imprisonment. Additionally, the Brazilian Public Procurement Law specifically targets bid rigging, providing for imprisonment, and a criminal fine. To prevent these different criminal provisions from interacting negatively and undermining the leniency program, the Competition Law expressly states that the execution of a leniency agreement requires the suspension of the statute of limitations and prevents denunciation of the leniency beneficiary for each of the aforementioned crimes. Once the leniency agreement has been fully complied with by the agent, the punishments for the crimes will automatically cease". See Reinaldo Diogo Luz and Giancarlo Spagnolo, 'Leniency, Collusion, Corruption, and Whistleblowing' (2017) 13 Journal of Competition Law \& Economics 729, 16.

82 Marcelo Calliari and Denis Guimarães note that "The Brazilian leniency regime has achieved reasonable international recognition”. See Marcelo Calliari and Denis Alves Guimarães, 'Brazilian Cartel Enforcement: FromRevolution to The Challenges of Consolidation’ (2011) 25 Antitrust Magazine 67, 69.

83 According to the OECD, Brazil's "anti-cartel programme is now widely respected in Brazil and abroad”. See OECD, Competition Law and Policy in Brazil - a Peer Review (n 8).

84 On the subject of global cartels and international cooperation between leniency programs, see Jay Pil Choi and Heiko Gerlach highlighting that Brazil is one of the countries that have a bilateral antitrust cooperation agreement with the U.S. Department of Justice. See Jay Pil Choi and Heiko Gerlach, 'Global Cartels, Leniency Programs and International Antitrust Cooperation' (2012) 30 International Journal of Industrial Organization 528.

85 According to Linhares and Fidelis, the enactment of the 2011 Brazilian Competition Act "represents a new momentum of development of the Brazilian Leniency Program", which is marked by an "accentuated cartel prosecution activity". See Amanda Athayde Martins Linhares and Andressa Lin Fidelis, "Nearly 16 Years of the Leniency Program in Brazil : Breakthroughs and Challenges in Cartel Prosecution' (2016) 3 Antitrust Chronicle 39, 5. 
schemes and other criminal practices, like money laundering. ${ }^{86}$ This situation required increased cooperation between the Brazilian competition agency and law enforcement authorities in the criminal sphere, especially regarding the interrelation between the antitrust leniency program and the rewarded collaboration regulation, introduced by the 2013 Organized Crime Act. ${ }^{87}$

\section{b. Criminal law}

Collaboration agreements were formally introduced in Brazilian criminal law in 2013, when the current Organized Crime Act came into force and provided a specific regulation for so-called "rewarded collaboration". Prior to the current Organized Crime Act, several laws already provided for the granting of benefits to offenders who cooperated with criminal investigations. ${ }^{88}$ However, none of them had established that this transaction would occur through written agreements between law enforcement authorities and defendants. ${ }^{89}$

86 This has occured mainly in the context of the so-called "Operation Car Wash", as noted by Burnier and Oliveira: "The challenges faced by the Brazilian competition authority in bid rigging fighting have become exponential in the context of the world-famous "Car Wash" investigation, the largest corruption scheme uncovered in Latin America". See Burnier and Fernandes (n 7).

87 Ribeiro, Cordeiro and Guimarães (n 5) 196-198.

88 As highlighted by Walter Barbosa Bittar, the development of these criminal policies in Brazil is linked to "contemporary criminality, particularly, to what we intend to classify as large-scale crimes, whose justification for legal provision, although diffuse, is oriented to the protection of diffuse and collective legal goods (...)”. See Walter Barbosa Bittar, Delação Premiada: Direito Estrangeiro, Doutrina e Jurisprudência (Lumen Juris 2011) 89. Cooperation in the criminal field can be understood as a recent phenomenon in Brazilian law, which only started to grant benefits in exchange for the handing over of accomplices in the final decades of the $20^{\text {th }}$ century. See Bottino (n 36). Regarding the development of the Brazilian legislation about the subject, see also: Natália Oliveira de Carvalho, A Delação Premiada No Brasil (Lumen Juris 2009) 99; Luiz Flávio Gomes and Raúl Cervini, Crime Organizado - Enfoques Criminológicos, Jurídicos (Lei 9.034/95) e Político-Criminal (Revista dos Tribunais 1997) 164.

89 As stressed by Marcelo Costenaro Cavali, when analyzing the previous legislation: "there was no provision of an agreement that could be concluded by the parties and validated by the judge: if cooperation was provided, the judge would grant the benefits on the occasion of the sentence". See: Cavali (n 36) 4. In this respect, Matheus Felipe de Castro notes that before the 2013 Organized Crime Act cooperation between defendants and enforcement authorities "was not designed as a 
In 1990, the Heinous Crime Act established that, for serious crimes committed by a group of criminals, the participant who reported the offense to authorities and cooperated against former co-conspirators could receive a penalty reduction. ${ }^{90}$ Over subsequent years, similar provisions were enacted to encourage offender cooperation in the prosecution of other crimes. The former Organized Crime Act, enacted in 1995, permitted a reduction of the offender's imprisonment sentence by up to two-thirds when their cooperation helped to elucidate the case. ${ }^{91}$ In the same year, a legislative amendment established that these benefits could also be granted in the investigation of financial, tax and economic crimes. ${ }^{92}$ In 1998, the Anti-Money Laundering Act set forth a similar rule. ${ }^{93}$ Finally, in 1999, the Victim and Witness Protection Act extended this possibility to all offenses committed by more than one criminal ${ }^{94}$ and introduced, for the first time and in specific cases, the granting of a judicial pardon to cooperators. ${ }^{95}$

All these statutes regulated the granting of benefits to cooperating offenders in a similar fashion. This regulation occurred mainly in the sphere of substantive criminal law, without the enactment of any procedural provisions. ${ }^{96}$ None of these laws explicitly contemplated written agreements between offenders and law enforcement authorities as a mechanism to determine the cooperator's obligations and benefits. According to this body of law, the granting of benefits to cooperating defendants stems from a unilateral assessment by the judge, and not from an agreement reached

legal transaction, but as a voluntary act between the defendant and the judge, in which the latter, due to his discretionary power, could grant the legal favor to collaborators who had effectively met the legal requirements". See Matheus Felipe de Castro, 'Abrenuntio Satanae! A Colaboração Premiada Na Lei $\mathrm{N}^{\circ}$ 12.850/2013: Um Novo Paradigma de Sistema Penal Contratual?' (2018) Revista de Estudos Criminais 171, 202. On the same topic: Bottino (n 36) 7.

90 Law 8072 [1990], arts 7-8.

91 Law 9034 [1995], art 6.

92 Law 9080 [1995], arts 1-2.

93 In addition to reducing the collaborating offender's punishment, the 1998 AntiMoney Laundering Act provided for the substitution of an imprisonment sentence by a penalty of restriction of rights. See Law 9613 [1998], art $1 \rrbracket 5$.

94 Despite the initial controversy over the scope of its application, the position established in Brazilian case law was that the benefits provided by the 1999 Victim and Witness Protection Law were applicable to any crime. See STJ, REsp 1109485 [2012].

95 Law 9807 [1999], art 14.

96 Vasconcellos (n 39) 81. 
with the law enforcement authorities. ${ }^{97}$ Such provisions are sentencing phase rules, which authorize the judge to acknowledge the offender's cooperation and grant him, unilaterally, the benefits provided for by law.

In 2003, in the investigation of an international money laundering scheme, the Federal Public Prosecution Office concluded what is considered the first written collaboration agreement in Brazilian modern criminal law, although at the time no statutory provision authorized this type of negotiation. ${ }^{98}$ Appealing to constitutional and legal provisions, including the Code of Civil Procedure, the Federal Public Prosecution Office and an accused signed a written contract that detailed the accused's obligations and defined his benefits. Although this particular agreement was considered valid by the Judiciary, ${ }^{99}$ this kind of arrangement did not become a common practice in Brazil, since there was no clear statutory basis for it. ${ }^{100}$

Only in 2013, with the enactment of the current Organized Crime Act, did an express provision come into force in Brazilian criminal law permit-

97 In the prosecution of drug trafficking, there was - for a short period of time - a different legal provision:

In 2002, a law was enacted allowing the Public Prosecution Office and the defendant to negotiate a deal that could lead to the "suspension of the procedure or the reduction of the penalties”. See Law 10409 [2002], art 32\$2. This provision, however, was revoked in 2006.

Regarding the subject, Matheus Felipe de Castro affirms that the "recent Brazilian laws, since Law 8.072/1990, with the rare exception of Law 10.409/2002, which attempted to provide a similar regulation, but was quickly revoked, never granted to the rewarded collaboration the character of a deal that is freely settled by the parties, as now happens in the legislation under analysis”. See Castro (n 89) 200.

98 The agreement was concluded, on 16 December 2003, between the Federal Public Prosecution Office and a defendant in a criminal proceeding before the Federal Justice in the State of Paraná, in the investigation known as "Operation Banestado”. See JFPR, AP 2003.70.00.056661-8 [2003]. According to the Federal Public Prosecution Office, this arrangement can be considered the first written collaboration agreement in Brazil. See Ministério Público Federal, 'Lava-Jato FAQ' < http://www.mpf.mp.br/grandes-casos/lava-jato/faq > accessed 28 September 2019. Along the same lines, see Cibele Benevides Guedes da Fonseca, Colaboração Premiada (Del Rey 2017) 85.

99 In this regard, see TRF4, COR PAR 035046-4 [2009].

100 Highlighting the absence of legal basis for this kind of agreement, Heloisa Estellita stated that "in the current stage of our positive law, the conclusion of any agreement between the prosecution and the defendant or between the judge and the defendant is illegal". See Heloísa Estellita, 'A Delação Premiada Para a Identificação Dos Demais Coautores Ou Partícipes: Algumas Reflexões à Luz Do Devido Processo Legal' (2009) 17 Boletim IBCCRIM 2, 2. 
ting written agreements between law enforcement authorities and offenders willing to cooperate with investigations. In the system created by the Organized Crime Act, negotiations take place between the accused and the public prosecutor or the chief of police. ${ }^{101}$ The judge does not take part in the negotiations and only assesses the agreement after the parties have reached a consensus. ${ }^{102}$ The collaboration agreement must be recorded in writing and contain the collaborator's statement, the expected outcomes for the investigation, the conditions of the investigating authorities' proposed agreement and, finally, the signatures of all those involved in the negotiations, i.e., the collaborator, his or her lawyer and the law enforcement authorities. ${ }^{103}$ Unlike previous statutes, the Organized Crime Act has also introduced specific procedural provisions for the negotiation and development of the cooperative relationship between law enforcement authorities and offenders. ${ }^{104}$ It establishes the cooperator's rights during the process ${ }^{105}$ defines confidentiality rules for the collaboration agreement ${ }^{106}$ and permits the defendant to withdraw the proposal. ${ }^{107}$

Although it innovated in several ways in comparison to previous legislation, the Organized Crime Act adopted similar wording regarding the granting of benefits to cooperators. According to the Organized Crime Act, "the judge may, at the request of the parties, grant judicial pardon, reduce the imprisonment sentence by up to two thirds, or replace it with a penalty of restriction of rights". ${ }^{108}$ At the same time, the Organized Crime Act provided that - as a reward for cooperative behavior - the Public Pros-

101 See Brazilian Organized Crime Act 2013, art $4 \$ 2$. The possibility for chiefs of police to negotiate collaboration agreements was subject to extensive discussion, especially regarding the risk of invading the constitutional remit of the Public Prosecution Office. In 2018, the Brazilian Federal Supreme Court decided that the provision was constitutional and validated the powers of chiefs of police to negotiate collaboration agreements. See STF, ADI 5508 [2018].

102 ibid art $4 \$ 6$.

103 ibid art. 6.

104 According to Pereira, prior to the 2013 Organized Crime Act "the legislator had not bothered to establish any procedural rules to the rewarded collaboration, what created difficulties and uncertainties", and the new legislation overcame "the criticisms to the regulatory insufficiency on important procedural aspects". See Frederico Valdez Pereira, Delação Premiada: Legitimidade e Procedimento (Juruá Editora 2016) 119-120. In this regard: Vasconcellos (n 39) 81.

105 Brazilian Organized Crime Act 2013, art 5.

106 ibid art 7.

107 ibid art $4 \$ 10$.

108 ibid art 4. 
ecution Office may in some circumstances drop the charges against the cooperating defendant. ${ }^{109}$

Since the enactment of the Organized Crime Act, the practice of the rewarded collaboration regulation has rapidly evolved, with major impact on Brazilian criminal justice, especially in the investigation of corporate crimes perpetrated within legitimate companies and corrupt acts performed by public officials and elected representatives. ${ }^{110} \mathrm{~A}$ central stage for the development of the practice of collaboration agreements was the socalled "Operation Car Wash", which since 2014 has investigated criminal practices related to cartels, corruption, and money laundering in the bidding process of Petrobras, the Brazilian state-owned oil company. ${ }^{111}$ In August 2014, the first collaboration agreement in "Operation Car Wash" was signed by the Federal Public Prosecution Office and a former Petrobras director. In March 2015, one year after the investigations began, 12 agreements had been concluded, a number that rose to 44 by March 2016 and to 155 by March 2017. ${ }^{112}$ At the end of 2017, data from the Federal

109 According to the Organized Crime Act, this benefit can only be granted to an offender that was not the leader of the criminal organization and was the first to effectively cooperate. ibid art $4 \$ 4$.

110 Concerning the features of the criminality investigated in the Brazilian experience with the rewarded collaboration, see section II.3.

111 "Operation Car Wash" is the name of a vast group of proceedings that investigate a "massive alleged malfeasance by corporate, as well as political, elites surrounding the enormous state-run oil company Petrobrás". See Prado and Carson (n 13) 753. The investigations started in 2014 and are yet to be finished. For more information, see section II.2.

112 According to data released by the Federal Public Prosecution Office. See Ministério Público Federal, 'Lava Jato: Em Um Ano, Foram Propostas 20 Ações Criminais Contra 103 Pessoas Na Primeira Instância' (Ministério Público Federal, 17 March 2015) <http://combateacorrupcao.mpf.mp.br/atuacao-do-mpf/noticias /lava-jato-em-um-ano-foram-propostas-20-acoes-criminais-contra-103-pessoas-naprimeira-instancia $>$ accessed 28 September 2018; Ministério Público Federal, 'Dois Anos Da Lava Jato: R\$2,9 Bi Já Foram Recuperados' (Ministério Público Federal, 16 March 2016) <http://www.mpf.mp.br/pr/sala-de-imprensa/noticias-pr /dois-anos-da-lava-jato-r-2-9-bi-ja-foram-recuperados-1> accessed 28 September 2018; Ministério Público Federal, 'Lava Jato Completa Três Anos Com Mais de 180 Pedidos de Cooperação Internacional' (Ministério Público Federal, 17 March 2017) <http://www.mpf.mp.br/pr/sala-de-imprensa/noticias-pr/lava-jato-complet a-tres-anos-com-mais-de-180-pedidos-de-cooperacao-internacional $>$ accessed 28 September 2019. 
Public Prosecution Office pointed to almost 300 collaboration agreements concluded under "Operation Car Wash". ${ }^{113}$

The large-scale use of the collaboration agreements in the prosecution of corporate crimes and corruption schemes received intense media coverage. ${ }^{114}$ The group of individuals who entered into such agreements include shareholders and executives of some of Brazil's largest companies, as well as senior politicians. ${ }^{115}$ Due to the list of high-profile defendants, the extent of the reported crimes and the amount of evidence gathered through these agreements, collaboration agreements became a hot topic both in Brazilian legal scholarship and in public debates, ${ }^{116}$ also drawing international attention. ${ }^{117}$

\section{The legal structure of Brazilian leniency policies}

The antitrust leniency program, provided for in the 2011 Competition Act, and the rewarded collaboration regulation, established by the 2013 Organized Crime Act, enable the granting of benefits to offenders who choose to cooperate with official investigations. The objective of both policies is not simply to obtain a confession from offenders, but rather create a coop-

113 According to data presented by the Federal Prosecutor General in December 2017. See Alessandra Modzeleski, 'Lava Jato Tem 293 Acordos de Delação Premiada Homologados, diz PGR' (G1 Política, 4 December 2017) <https://g1.globo .com/politica/noticia/lava-jato-teve-293-acordos-de-delacao-homologados-diz-pgr .ghtml> accessed 28 September 2018.

114 Melo (n 14) 60.

115 On this matter, see section II.2 and II.4.

116 For more information on the increase of media coverage and academic interest in the subject, as well as on its importance, see: Armando Castro and Shaz Ansari, 'Contextual "Readiness" for Institutional Work. A Study of the Fight Against Corruption in Brazil' (2017) 26 Journal of Management Inquiry 351.

117 On this subject, the Organisation for Economic Co-operation and Development - OECD has highlighted the importance of collaboration agreements in the prosecution of government corruption in Brazil. See OECD, 'OECD Economic Surveys: Brazil' (2018) 35. A recent article published in "The Economist" has praised the Brazilian experience with collaboration agreements, stating that it allowed investigations to "cut through the country's once-untouchable politicians, thanks to evidence provided by bribe-paying businessmen desperate to stay out of jail”. See 'A Deal You Can't Refuse: The Troubling Spread of PleaBargaining from America to the World' The Economist (London, 9 November 2017) < https:/www.economist.com/international/2017/11/09/the-troubling-spre ad-of-plea-bargaining-from-america-to-the-world $>$ accessed 27 October 2018. 
erative relationship with law enforcement authorities to ensure more effective prosecution of co-conspirators. ${ }^{118}$ In both cases, the development of this relationship is preceded by an open negotiation between offenders and law enforcement authorities and by the signing of a written agreement that establishes the terms and conditions of the cooperation.

Over recent years, the number of antitrust leniency agreements and collaboration agreements has increased substantially, turning negotiations between offenders and law enforcement authorities into a common practice. This phenomenon is new to Brazilian law, which until recently had evolved largely oblivious to the global movement of expansion of consensual mechanisms in criminal proceedings, ${ }^{119}$ which led - under the clear influence of the U.S. plea bargaining system $-^{120}$ many countries of continental tradition to introduce negotiating mechanisms between procedural parties in criminal cases. ${ }^{121}$

With the exception of the 1995 Small Claims Act, which provided guidelines for the judicial treatment of minor crimes and allowed for consensual resolution of these cases, ${ }^{122}$ Brazil had up until recently no legal provisions enabling negotiations between public authorities and accused

118 In neither of the programs is the mere confession of a defendant's own acts sufficient to justify the conclusion of an agreement.

119 For an overview of this movement, see: Thaman (n 28) 952, who notes that "'Consensual' procedural forms are part and parcel of criminal procedure reforms worldwide".

120 For a strong criticism of this influence, see Schünemann, 'Zur Kritik Des Amerikanischen Strafprozessmodells' (n 25) 555-575.

121 Although they share common features, the experiences of each country with these mechanisms have specific characteristics. Concerning the subject, see: Langer (n 28) 3-4. When analyzing the experiences of Germany, France, Italy and Argentina with consensual mechanisms in the criminal procedure, the author points out that: "Not only has each of these jurisdictions adopted a version of plea bargaining different from the American model, but also, each one of these jurisdictions has adopted forms of plea bargaining different from one another".

122 The 1995 Small Claims Act introduced two negotiation mechanisms between the Public Prosecution Office and defendants: the "criminal transaction" and the "conditional suspension of the process". The "criminal transaction" can be used in proceedings related to crimes with a maximum penalty of up to 2 years, (art. 76), while the "conditional suspension of the process" is restricted to crimes with a minimum penalty not superior to 1 year (art. 89). See Brazilian Small Claims Act 1995, arts 76 and 89. Through a "criminal transaction", prosecutor and defendant negotiate and establish a penalty of fines or sanctions of restriction of rights. In the case of "the conditional suspension of the process", the procedure is interrupted immediately after the receipt of the indictment and the de- 
in criminal investigations. ${ }^{123}$ Moreover, informal negotiations in criminal proceedings did not become a common practice in Brazilian criminal justice, as remarkably occurred in Germany in the final decades of the twentieth century. ${ }^{124}$ Thus, in the vast majority of criminal investigations, there was no space for consensual arrangements, with the Public Prosecution Office being bound by the rules of compulsory prosecution and the defendant unable to dispose of the case by confessing to the charged crimes.

The Competition Act and the Organized Crime Act changed this scenario, setting up a room for legitimate negotiations between cooperating defendants and law enforcement authorities. Both the antitrust leniency program and the rewarded collaboration regulation set up a communication forum where offenders and law enforcement authorities can negotiate, over several rounds and over a long period, a written agreement that will have a decisive impact on the official investigation of serious crimes.

a. The negotiation dynamic: consensual arrangements, written agreements and informal communication

The statutory frameworks for both the antitrust leniency program and the rewarded collaboration regulation have a common feature: they establish a mechanism of inter-party negotiation that may lead to a written consensual arrangement between law enforcement authorities and offenders. The central aspect of the two legal mechanisms is basically the same: law enforcement authorities negotiate with offenders in order to obtain information and evidence that are useful in the investigation of criminal activities committed by co-conspirators, offering in return certain benefits. ${ }^{125}$

fendant is subjected to a probation period, during which they must observe certain conditions, such as repairing the damage, not going to certain places and appearing, periodically, before the court (these conditions do not have, however, the character of criminal punishment). See STF, HC 108914 [2012]. In both cases, the consensual resolution does not entail recognition of the facts or of individual guilt, so that, in case of breach of agreement, the criminal prosecution continues from the stage in which the agreement was concluded. See STF, RE 795567 [2015] and STF RE 602072 QO-RG [2009].

123 Vasconcelos, Barganha e Justiça Criminal Negocial: Análise Das Tendências de Expansão Dos Espaços de Consenso No Processo Penal Brasileiro (n 43).

124 On the development of German practice of negotiated judgments ("Verständigung”), see section IV.2.

125 On the rationale of this type of exchanges, see section III. 
Both policies clearly separate the negotiation period from the moment of the conclusion of the written agreement. Thus, it is possible that, despite the submission of a proposal by a defendant, the parties do not reach an understanding and do not conclude the transaction. The rejection of an application is expressly regulated by both statutes. According to the Competition Act, the rejection of a leniency proposal does not imply a confession, nor an acknowledgment of the illegality of the conduct reported by the applicant. ${ }^{126}$ The Competition Act also provides that the rejected leniency proposal should not be disclosed. ${ }^{127}$ The Organized Crime Act establishes that if one of the parties withdraws from the proposal, the evidence produced by the cooperating offender cannot be used exclusively against him. ${ }^{128}$

The possibility of reducing penalties through cooperation with investigations has long existed in Brazilian criminal legislation. The main novelty brought by the Competition Act and the Organized Crime Act is the setting up of a legitimate room for negotiation between law enforcement authorities and defendants, giving the parties an opportunity to meet securely and, through active and open communication, discuss the conditions needed to reach an agreement that benefits both sides. Moreover, both statutes establish that the agreement must be written and contain the conditions set forth throughout the negotiation, ${ }^{129}$ creating a kind of negotiation that is clearly new to the Brazilian legal system. ${ }^{130}$

Although the Competition Act and the Organized Crime Act establish a room for negotiation that enables frank interaction between the law enforcement authorities and defendants, they do not establish rigid rules for the communication process between the parties before the agreement is signed. ${ }^{131}$ Therefore, in the timeframe between the defendant's application and the actual signing of the agreement, the contact between law enforce-

126 Brazilian Competition Act 2011, art $86 \rrbracket 10$.

127 ibid $86 \$ 9$ o.

$128 \mathrm{ibid}$ art $4 \$ 10$. With respect to this subject and to the several interpretations derived from this legal provision, see Vasconcellos, Colaboração Premiada No Processo Penal (n 39) 290-291.

129 Brazilian Organized Crime Act 2013, art 6 II, and Brazilian Competition Act

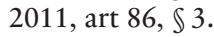

130 In previous legislations, benefits granted to cooperating defendants were not the result of an agreement between law enforcement authorities and offenders, but rather the result of a unilateral decision from a judicial body, carried out after the offender's cooperation.

131 Apart from the definition of competences and of certain prohibitions and guarantees, the legislation did not regulate the negotiation procedure for these 
ment authorities and defendants tends to be informal, ${ }^{132}$ with parties approaching each other and exchanging information gradually up to the point at which there is sufficient trust and confidence on both sides for the conclusion of the agreement. ${ }^{133}$ According to the legal rules, adjudicative

agreements, which are now regulated by guidelines and orientations from the authorities responsible for their application. Regarding the antitrust leniency program, see the Internal Regulation of the Administrative Council for Economic Defense (CADE) <http://en.cade.gov.br/topics/legislation/internal-regulatio $\mathrm{n}>$ accessed 28 October 2018.

132 According to Gustavo Schiefler, the negotiations prior to the formalization of leniency agreements can be described as examples of "public-private dialogues", which, he says, are located "in the midst of the duality that emerges between the search for consensuality and an aggravated culture of distrust about public-private relationships" and marked by being "potentially informal and immune to the control mechanisms". See Gustavo Henrique Carvalho Schiefler, Diálogos Público-Privados: Da Opacidade à Visibilidade Na Administração Pública (DJur Universidade de São Paulo 2016) 19. Concerning collaboration agreements, Alexandre José Garcia de Souza points out that "although there is no specific legal provision as to the procedure to be followed, it is possible to observe that, in current investigations, meetings are being held previously to the formalization of the collaboration agreement", but, despite having an "absolutely fundamental role in the conduction of the investigations", those meetings are usually not documented. According to the author, "in our judicial reality, the terms of collaboration don't come with any records of the negotiations prior to the formalization". He affirms that the need for documentation is especially important due to news of "sudden changes of version" and "harassment of defendants that are incarcerated" in the context of the Car Wash Operation. See Alexandre José Garcia de Souza, 'Colaboração Premiada: A Necessidade de Controle Dos Atos de Negociação’ (2017) 25 Boletim IBCCRIM 12, 12-13.

133 The regulation issued by the Brazilian competition authority expressly allows defendants to apply to the antitrust leniency program orally and confidentially, over a series of meetings. See CADE's Internal Rules, art. 241). In the same vein, in relation to the negotiation of collaboration agreements: "The negotiation phase, prior to the conclusion of the agreement, is always very difficult. The member of the Federal Public Prosecution Office will not commit to the granting of a benefit to the collaborator without knowing, beforehand, exactly how the investigated party can cooperate effectively with the investigations (statements, documents, bank statements, etc.). The collaborator, on the other hand, has a reasonable fear of self-incriminating preliminarily, reporting what he knows and presenting evidence, without knowing if the collaboration agreement will actually be concluded. What to do in the face of this dilemma? The establishment of a minimum trust relationship is essential to the development of the negotiations. Without that element, it is impossible to imagine the conclusion of an agreement between the parties. However, there is something con- 
bodies should not take part in negotiations, ${ }^{134}$ which gives parties (defendants and enforcement authorities) to meet and discuss the conditions of arrangements without many formalities. In this scenario, it is common that negotiations carried out under the antitrust leniency program last for several months. ${ }^{135}$ Much like the process in the antitrust sphere, the negotiations preceding the signing of a collaboration agreement are marked by informality and confidentiality, with the Public Prosecution Office and the defendants bargaining over several rounds and for long periods before a formal written arrangement is concluded. ${ }^{136}$

\section{b. Terms of trade}

\section{i. Benefits: immunities and reduction of penalties}

The development of leniency policies takes place through the construction of an incentive structure that makes it attractive for offenders to defect from criminal organizations (or cartels) and cooperate with law enforce-

crete, besides that subjective bond, that can effectively leverage the negotiations, which is: a preliminary agreement whereby the collaborating party reveals a sample of the evidence they have and the investigators commit not to use it until formally signing the collaboration agreement". See Cleber Masson and Vinícius Marçal, Crime Organizado (Método 2006) 223-224.

134 Brazilian Organized Crime Act 2013, art 4 \$6; and Brazilian Competition Act 2011, art 86.

135 According to the Guidelines of CADE's Antitrust Leniency Program: "As the information and documents are submitted by the leniency applicant, the negotiation period can be extended by means of 'Meeting Terms' ('Termos de Reunião' in its Portuguese acronym) (art. 201, III and IV, RICADE). Therefore, the negotiation of a Leniency Agreement ends when the interim deadlines defined by SG/CADE are concluded (art. 204, introductory paragraph, RICADE)". See CADE (n 131). Art. 239, paragraph 3, of CADE's Internal Rules, states that these "interim deadlines" are defined by CADE's General Superintendence, in each case.

136 According to a report of the Federal Public Prosecution Office, the negotiation of the 77 agreements signed with executives from a Brazilian business conglomerate has demanded " 48 meetings between the parties, amounting to almost 10 months of negotiation to maximize the disclosure of the illicit acts and of the corroborating evidence". See Ministério Público Federal, 'Relatório de Resultados Do Procurador-Geral Da República: Diálogo, Unidade, Transparência, Profissionalismo, Efetividade: 2015-2017' (2017) 24 <http://www.mpf.mp.br/con heca-o-mpf/gestao-estrategica-e-modernizacao-do-mpf/sobre/publicacoes/pdf/rela torio-gestao-pgr-2015-2017.pdf $>$ accessed 28 June 2019. 
ment authorities. ${ }^{137}$ Although there is a wide range of benefits that can be granted to cooperators, the main incentive normally set forth by leniency policies is the granting of immunity or the reduction of penalties. ${ }^{138}$ This is the model adopted by the Brazilian Competition Act and the Organized Crime Act.

According to the Competition Act, antitrust leniency agreements may lead to the non-imposition of administrative penalties or to their reduction by betwen one-third and to two-thirds. ${ }^{139}$ In criminal proceedings, the signing and fulfillment of an antitrust leniency agreement always leads to immunity from criminal prosecution in regard to crimes directly related to the practice of cartel, such as the crimes established by the Economic and Tax Crimes Act and by the Public Procurement Act. ${ }^{140}$

The rewarded collaboration regulation established by the Organized Crime Act has a similar structure: besides allowing the granting of immunity from criminal penalties, whether through judicial pardon or by dropping of charges by the Prosecution Office, it provides for the possibility of reducing the imprisonment sentence by up to two thirds, or its replacement with a penalty of restriction of rights.

Thus, the leniency benefits expressly provided for in these two statutes are strictly related to the offenders' criminal punishment. There is not, for example, a provision permitting financial rewards in exchange for cooperation, as in other countries. ${ }^{141}$ Brazilian leniency policies also offer cooperators no relief from civil liability, as occurs in German competition law ${ }^{142}$

137 For a discussion on the incentive structure of leniency policies, see section III.2.

138 Some authors argue, based on econometric tests, that a simple softening of the penalties would not, in some cases, create a sufficient incentive to stimulate cooperation, suggesting therefore the granting of financial rewards. See Maria Bigoni and others, 'Fines, Leniency, and Rewards in Antitrust' (2012) 43 RAND Journal of Economics 368.

139 Brazilian Competition Act 2011, art 86.

140 ibid art. 87.

141 Regarding this topic, see Spagnolo, 'Leniency and Whistleblowers in Antitrust' (n 30).

142 The "Ninth Amendment of the Act against Restrains of Competition" (ARC Gesetz gegen Wettbewerbsbeschränkunge) restricted the individuals and entities that can file damage claims against the cooperator. In this regard: "whereas leniency applicants thus far only benefitted in relation to the imposition of fines, applicants will now also benefit from restricted civil damages liability. In this regard, they only have to compensate for damages incurred by their direct or indirect purchasers. In relation to other damaged parties, leniency applicants are liable only if these parties cannot obtain full compensation from the other 
or in the U.S. leniency program. ${ }^{143}$ In this regard, leniency beneficiaries are in the same legal situation as the others responsible for the reported illegal activity. ${ }^{144}$

Although the nature of the benefits under the antitrust leniency program and the rewarded collaboration regulation is similar, the definition of the advantages in particular cases is subject to different rules in each legislation.

In the same manner as the U.S. antitrust leniency program, ${ }^{145}$ the Brazilian Competition Act establishes a "winner-takes-all" system, ${ }^{146}$ which is deliberately aimed to create a race between cartel participants to be the first to blow the whistle to the competition authority. The Competition Act permits the conclusion of only one leniency agreement with a corporation per investigation. ${ }^{147}$ In cases where the application was submitted before the Brazilian competition authority had knowledge of the reported cartel, the cooperating agent will be entitled to obtain full immunity, both in criminal and administrative proceedings. ${ }^{148}$ When the competition authority was already aware of the offense before the leniency application, the co-

cartel members (Section 33e ARC new version)". See Freshfields Bruckhaus Deringer, 'Germany: Ninth Amendment of the Act against Restraints of Competition Enters into Force' (2017) <http://knowledge.freshfields.com/en/Global/r/35 11/germany_ninth_amendment_of_the_act_against_restraints_of $>$ accessed 28 September 2019 .

143 In the United States, the legislation "also reduced the successful leniency applicant's exposure in follow-on civil actions: unlike its conspirators who face joint and several liability for treble civil damages caused by the cartel, successful leniency applicants are liable only for the actual damages caused by their conduct if they provide 'satisfactory cooperation' to the private plaintiffs". See Maurice E Stucke, 'Leniency, Whistle-Blowing and the Individual: Should We Create Another Race to the Competition Agency?' in Caron Beaton-Wells and Christopher Tran (eds), Anti-Cartel Enforcement in a Contemporary Age : Leniency Religion (Hart Publishing 2015) 309.

144 In a case judged by the Superior Court of Justice, it was highlighted that the benefits of the antitrust leniency are restricted to the criminal and administrative spheres. Pursuant to the Court, "the 'award' granted to the one who adheres to the leniency program is restricted to the administrative and criminal spheres, without any legal mention of civil claims from individuals that were harmed by the conducts practiced against the market." See STJ, REsp 1554986 [April 2016].

145 Jindrich Kloub, 'Leniency as the Most Effective Tool in Combating Cartels', 2009 Latim American Competition Forum (Latin American Competition Forum 2009) 6.

146 Martinez (n 8) 261.

147 Brazilian Competition Act 2011, art $86 \$ 1 \mathrm{I}$.

148 ibid art 86, $\$ 1$ II. 
operator will only be eligible for a reduction of up to two-thirds of the administrative penalties ${ }^{149}$, while still receiving full immunity from criminal prosecution. ${ }^{150}$

On the other hand, in the Brazilian Organized Crime Act, there is no legal restriction on the number of offenders who may apply for a collaboration agreement in a criminal investigation. Nor is there a single criterion defining the benefits granted to the cooperating offender. The central provision of the rewarded collaboration regulation authorizes judicial bodies to, at request of the parties, grant judicial pardon, reduce imprisonment sentences by up to two thirds or replace them with penalties of restriction of rights. ${ }^{151}$ The main rule regarding the criteria for defining the benefits establishes that "in any case, the granting of the benefit shall take into account the personality of the cooperating offender, the nature, circumstances, severity and social repercussion of the criminal act and the effectiveness of the cooperation". 152

Thus, while the antitrust leniency program is designed in the Competition Act under the "winner-takes-it-all" model, where full immunity is granted to the first agent to report the violation regardless of the set of evidence presented, the collaboration agreement is structured in a system of "quid-pro-quo" agreements, in which the granting of benefits is evaluated in each negotiation according to the relevance of the submitted evidence. ${ }^{153}$

ii. Duties: cooperation with the investigations

The antitrust leniency program and the rewarded collaboration regulation both establish the same central prerequisite for granting benefits to coop-

149 ibid art $86, \mathbb{1} 1$ o, II.

150 In criminal proceedings, the effects of the antitrust leniency agreement are always the same, regardless of the time of its signing: the extinguishment of criminal punishment for the crimes related to the practice of cartel (ibid art 87).

151 ibid art 4.

152 ibid art $4 \$ 1$.

153 For an economic analysis of the difference between these two types of leniency programs, see Eberhard Feess and Markus Walzl, 'Quid-pro-Quo or WinnerTakes-It-All? An Analysis of Corporate Leniency Programs and Lessons to Learn for US and EU Policies' (2005) METEOR Research Memorandum 059, Maastricht University School of Business and Economics $<$ https://cris.maastrichtuniv ersity.nl/portal/files/1144059/guid-89205720-706f-4ddb-89a8-3aa1e71508f8-ASSE T1.0> accessed 18 June 2019. 
erating defendants: effective and useful cooperation with official investigations against co-conspirators. According to the Competition Act, an antitrust leniency agreement should lead to the identification of other agents involved in the cartel and assist the competition authority in gathering information and evidence against them. ${ }^{154}$ Similarly, the Organized Crime Act establishes that collaboration agreements must lead to one or more of the following outcomes: a) identification of the members of the criminal organization and the crimes committed by them; b) disclosure of the criminal organization's structure; c) prevention of future crimes by the criminal organization; d) recovery of proceeds from illegal activities; e) the victim's location, with his or her physical integrity preserved. 155

Both the Competition Act and the Organized Crime Act design an incentive structure that clearly links the level of the granted benefits to the relevance and usefulness of the cooperation. The Competition Act provides that, when the cooperating offender does not receive full immunity, a penalty reduction should be granted according to the effectiveness of his or her cooperation. ${ }^{156}$ Similarly, the Organized Crime Act determines that the granting of benefits in collaboration agreements should take into account, among other factors, the usefulness of the cooperation. ${ }^{157}$ It also establishes that, if the cooperation proves to be especially helpful, the Public Prosecution Office and the chief of police may request the judge to grant a judicial pardon. ${ }^{158}$

In both criminal and antitrust arenas, the introduction and development of leniency policies are based on the need to increase the effectiveness of the prosecution of organized crime and cartels. ${ }^{159}$ Thus, the main intended purpose of these leniency policies is to maximize the state's ca-

154 Brazilian Competition Act 2011, art 86 para I-II.

155 ibid art 4.

156 ibid art $86 \rrbracket 4$ para II.

157 ibid art $4, \mathbb{} 10$.

158 ibid art $4, \mathbb{} \$$.

159 As can be seen in the legislative debate regarding the Bill 6578/2009, which gave rise to the 2013 Organized Crime Act: "the approval of this proposition is as a necessary measure for governmental action, for providing instruments for greater effectiveness in the results of criminal investigations of those executioners who organize to jeopardize Brazilian society." See Brazilian Chamber of Deputies - Committee of Public Security and Combat to Organized Crime, Report to Bill 6578/2009 (1 December 2010). On the same vein, the explanatory notes of the bill that introduced the leniency agreements in the former Competition Act state: "Leniency agreements are already being used in several jurisdictions (...) for its key role as an instrument for speeding and reducing the investi- 
pacity to prosecute and punish members of criminal organizations and cartels, through the creation of investigative channels to access information and evidence held by offenders. On the other hand, the antitrust leniency program and the rewarded collaboration regulation are not directly aimed at compensating the victims of the offenses. The Brazilian Competition Act does not establish, as a requirement for the closure of an antitrust leniency agreement, the obligation of compensating the damages to those affected by the cartel. In the Organized Crime Act, compensation of damages is also not a condition for the obtainment of benefits granted by the rewarded collaboration regulation. ${ }^{160}$

\section{c. Signing and fulfillment of the agreement}

Unlike previous criminal legislation that provided for the possibility of granting benefits to cooperating defendants, the Competition Act and the Organized Crime Act established a procedural framework for the negotiation and execution of antitrust leniency and collaboration agreements. Both statutes clearly separate the moment of closure of the agreement from the moment of assessment of its fulfillment, creating a division of functions between law enforcement authorities, responsible for the negotiation and the signing of the agreements, and adjudicative organs, responsible for analyzing the fulfillment of the arrangement.

The Competition Act assigns the task of negotiating and closing an antitrust leniency agreement to the General Superintendence of the Brazilian competition authority, the administrative body that investigates antitrust offenses. ${ }^{161}$ Given the repercussions of the antitrust leniency program in

gation costs in the identification of infractions to the economic order. In the case of the United States, the adoption of an amnesty program similar to the one proposed herein has led to an unprecedented increase in the detection of cartels, including international ones." See Senado Federal, 'Diário do Congresso Nacional' (35, 10 October 2000) 22276.

160 See Brazilian Organized Crime Act 2013, art 4.

161 This division of tasks is made explicit by Brazilian Competition Act 2011, art 86. Regarding this matter, the Guidelines for CADE's Antitrust Leniency Program state that: "the body responsible for negotiation and execution of Leniency Agreements is CADE's General Superintendence. CADE's Tribunal does not participate in the negotiation and/or execution of Leniency Agreements and is only responsible for declaring whether or not the leniency agreement has been fulfilled, at the time it issues a final decision on the corresponding administrative proceeding". See CADE, Guidelines: CADE's Antitrust Leniency Program 
criminal proceedings, the General Superintendence normally invites the Public Prosecution Office to participate in the signing of the agreement. ${ }^{162}$ In all important cases, antitrust leniency agreements are signed by the applicant, on one side, and the General Superintendence and representatives of the Public Prosecution Office, on the other.

The assessment of the fulfillment of an antitrust leniency agreement and the granting of benefits to the applicant are carried out by the Administrative Court of the Brazilian competition authority, the body responsible for adjudicating on antitrust violations and for applying the penalties provided by law. ${ }^{163}$ At the moment of the trial, after the end of the investigative phase, the Administrative Court must verify whether the agreement has been fulfilled and establish the reduction of the applicable administrative penalties. ${ }^{164}$ Whenever the fulfillment of the agreement is verified, the offender will automatically be immune to criminal prosecution.

The Organized Crime Act also determines that law enforcement authorities - in this case, the Public Prosecution Office or the chief of police - are responsible for negotiating and signing collaboration agreements. ${ }^{165}$ It is expressly prohibited for the judge to take part in the negotiation pro-

(2016) 17. <http://www.cade.gov.br/acesso-a-informacao/publicacoes-institucion ais/guias_do_Cade/guidelines-cades-antitrust-leniency-program-1.pdf/view> accessed 4 March 2019

162 In this regard: "It is CADE's standard practice to invite criminal prosecutors to sign the leniency agreement. This is viewed as means to help maximize benefits for potential applicants and to ensure that administrative and criminal liabilities are addressed together". See Martinez (n 8) 4. In the same respect, CADE's Guidelines on the antitrust leniency program clarify that: "Although articles 86 and 87 of Law No. 12.529/2011 do not expressly require the participation of the state and/or federal Public Prosecution Services for entering into a Leniency Agreement, CADE's consolidated experience shows that, in light of the criminal repercussions of a cartel, the Public Prosecution Service should be invited to cosign, as it is the competent body to bring criminal charges and initiate a public criminal action". See CADE (n 161) 17-18.

163 Brazilian Competition Act 2011, art $86 \rrbracket 4$.

164 According to an OECD report: “Once CADE's Tribunal adjudicates a case in which a leniency agreement took place, it must verify whether the applicant complied with the terms and conditions of the negotiated agreement. If full compliance is confirmed, the benefit, which may vary from a full immunity to a fine reduction, is granted". See OECD, 'Use of Markers in Leniency Programs' (Working Party No. 3 on Co-operation and Enforcement, 2014) $3<$ http://www. oecd.org/officialdocuments/publicdisplaydocumentpdf/?cote=DAF/COMP/WP3 (2014)9\&doclanguage=en $>$ accessed 4 March 2019.

165 Brazilian Organized Crime Act 2013, art $4 \$ 6$. 
cess. ${ }^{166}$ The Organized Crime Act provides, however, a procedural step that does not exist in the antitrust leniency program: the homologation of the agreement by the court. After the parties reach a common understanding and formalize the collaboration agreement in writing, it must be submitted to a court, which is responsible for verifying the agreement's "regularity, legality and voluntariness". ${ }^{167}$ If these requirements are met, the agreement is ratified; if not, the judicial body will reject it or make the necessary adjustments. ${ }^{168}$

The granting of benefits in collaboration agreements is also, as a rule, a responsibility of the courts, who may grant the judicial pardon, reduce the imprisonment sentence or substitute it for a sanction of restriction of rights. ${ }^{169}$ According to the text of the Organized Crime Act, the benefits will be granted in a particular case by a judicial decision rendered at the end of the process, when the terms of the agreement and their efficacy will be assessed. ${ }^{170}$ The Organized Crime Act also enables the Public Prosecution Office, in specific situations, not to press charges against the cooperating offender. ${ }^{171}$

4. The inventive practice of collaboration agreements: development and judicial support

a. Law in action, consensual innovations and the expansion of the room for negotiations

The Organized Crime Act and the Competition Act introduced an important innovation in Brazilian law by setting up rooms for negotiations that enable law enforcement authorities and offenders to openly negotiate with each other, conclude written agreements and act cooperatively in investigations of serious offenses. According to the text of both statutes, collaboration agreements and antitrust leniency agreements allow offenders to ob-

166 ibid.

167 ibid art $4 \$ 7$

168 ibid art $4 \$ 8$.

169 ibid art 4.

170 ibid art $4 \$ 11$.

171 According to the 2013 Organized Crime Act, this can only occur when the defendant is the first one to provide effective cooperation and is not the leader of the criminal organization. See Brazilian Organized Crime Act 2013, art. $4 \$ 4$ indents I and II. 
tain benefits such as immunities and penalty reductions and, at the same time, enable law enforcement authorities to obtain the assistance of offenders in the prosecution of former accomplices.

However, as the practice of the rewarded collaboration regulation developed, a distinctive phenomenon occurred: the participants in criminal proceedings expanded the room for negotiation created by the Organized Crime Act beyond its statutory boundaries. ${ }^{172}$ In several cases, collaboration agreements established solutions that are not expressly supported by the text of the Organized Crime Act. ${ }^{173}$ This expansion of the scope of negotiations is visible in numerous agreements signed over recent years, which contain clauses that go far beyond the statutory provisions. These agreements show that legal practitioners utilized the communication forum established by the Organized Crime Act to develop a broad and flexible system of negotiation, deciding consensually on various aspects of the criminal procedure. ${ }^{174}$

The consensual innovations brought by this "bold" practice of collaboration agreements ${ }^{175}$ created a clear detachment between the "law in action" and the statutory provisions of the Organized Crime Act. ${ }^{176}$ Legitimizing this detachment, the Federal Public Prosecution Office enacted, in 2018, an orientation note on the negotiation of collaboration agreements that endorsed the innovations created by legal practice, affirming the legality

172 Several authors note this phenomenon. Luis Manzano and Tiago Essado observe that several recent collaboration agreements bring "some legal innovations, not expressly provided in the legislation”. See Antonio Scarance Fernandes, 'O Equilíbrio Entre a Eficiência E O Garantismo E O Crime Organizado' in Denise Provasi Vaz and others (eds), Eficiência e garantismo no processo penal, vol 70 (LiberArs 2008) 208. For a detailed description and an emphatic defense of the innovations brought forth by the practice of collaboration agreements, see Mendonça (n 36) 53-101. For a critical view on the matter, see Bottino (n 36).

173 Analyzing the agreements concluded in the "Car Wash Operation", Salo de Carvalho affirms the existence of "sui generis" agréments. See Carvalho (n 36$) 516$. For a critical view on the new solutions generated by the use of rewarded collaboration: Gustavo Henrique Badaró, 'A Colaboração Premiada: Meio de Prova, Meio de Obtenção de Prova Ou Um Novo Modelo de Justiça Penal Não Epistêmica?' in Maria Thereza de Assis Moura and Pierpaolo Cruz Bottini (eds), Colaboração premiada (Revista dos Tribunais 2017) 142-143.

174 Fabiano Silveira speaks of "headlong jump towards a negotiated model" within Brazilian criminal justice. See Silveira (n 35) 119.

175 Expression used by Cavali (n 36) 256.

176 Along the same lines, Vasconcellos states, in a very critical way, that the use of rewarded collaboration in Brazil strongly contradicts several statutory provisions. See Vasconcellos, Colaboração Premiada No Processo Penal (n 36) 17. 
and usefulness of these consensual developments. ${ }^{177}$ Over the last years, the Brazilian judiciary has also provided strong support for the innovations engendered by legal practice, repeatedly validating collaboration agreements with provisions going far beyond the statutory provisions. ${ }^{178}$

The design of inventive solutions is a well-documented consequence of the use of negotiation mechanisms in the criminal justice systems of various countries. ${ }^{179}$ In the daily routines of the justice system, legal practitioners have incentives to explore the negotiation forum and the informal bonds of trust to develop new forms of consensual solutions. ${ }^{180}$ In the Brazilian scenario, several authors noted the recent development of the inventive practice of the rewarded collaboration regulation, and some studies have analyzed small groups of specific collaboration agreements.

Affirming the importance of evaluating the "judicial and practical reality", and after scrutinizing three agreements concluded at the early stage of "Operation Car Wash", Thiago Bottino concluded that "the examination of these documents reveals that the agreements were concluded without the benefits granted therein being based on the law". ${ }^{181}$ Canotilho and Brandao conducted a rigorous assessment of various clauses of two collaboration agreements, and criticized the "creation through case-law of solu-

177 This orientation note, approved by the Federal Public Prosecution Office in 2018 , is not binding upon prosecutors, but serves as guideline in the negotiation and conclusion of collaboration agreements. See Ministério Público FederalMPF, 'Orientação Conjunta no 1/2018: Acordos de Colaboração Premiada' (2018) <http:/www.mpf.mp.br/atuacao-tematica/ccr5/orientacoes/orientacao-co njunta-no-1-2018.pdf $>$ accessed 4 May 2019, hereinafter: MPF, Joint Orientation Note $1 / 2018$.

178 See item I.4.c.

179 For an analysis of the German experience, see Altenhain, Dietmeier and May (n 38). In the U.S., an interesting development is the negotiation of the so-called "Alford plea", through which the defendant accepts the imposition of criminal penalties, albeit not confessing to the investigated facts. See Stephanos Bibas, 'Harmonizing Substantive-Criminal-Law Values and Criminal Procedure: The Case of Alford and Nolo Contendere Pleas' (2003) 88 Cornell Law Review 1361.

180 Examining the German practice of negotiated criminal judgments, Martin Heger and Robert Pest recognize the obstacles to effective judicial control that arise from the informal nature of these negotiated solutions. See Heger and Pest (n 37 ) 468. In an important ruling issued in 2013, the German Federal Constitutional Court asserted that consensual mechanisms carry an inherent risk of disregard of legal rules by legal practitioners. See BVerfG, Urt. v. 19.3.2013 - 2 BvR 2628/10 u.a. = BVerfGE 133, 168, para 107.

181 Bottino (n 36) 7. 
tions that do not fit into the procedural models designed by legislation." 182 Vasconcellos examined five agreements and observed that "the practice carried out before courts has largely exceeded the statutory rules". ${ }^{183}$

The objective of this section is to provide a more solid and systematic picture of the innovations brought by the Brazilian practice of collaboration agreements. For that purpose, the first step was to assemble a larger group of collaboration agreements than seen in previous studies, which have focused basically on agreements that were widely disseminated in Brazilian press. From the analysis of the public records of criminal proceedings related to the so-called "Operation Car Wash" and other recent investigations into corrupt practices in Brazil, it was possible to compile a collection of 106 collaboration agreements, which enables a more comprehensive view of the innovations developed by legal practitioners through consensual arrangements. ${ }^{184}$ The examination of these documents reveals a model of transaction that is clearly dissociated from the legal rules provided for by the textual provisions of the Organized Crime Act.

Based on the examination of this data, the following topics analyze four central innovations engendered by the Brazilian practice of collaboration agreements: (i) the granting of benefits not provided by law for cooperators; (ii) the exact definition of imprisonment penalties through agreements concluded at early stages of criminal proceedings; (iii) the development of 'package deals', which set a single unified penalty for several wrongdoings confessed by the cooperator; (iv) the establishment of the possibility for the cooperator to serve imprisonment penalties in advance, before the pronouncement of the judicial verdict and sentence.

i. Granting of benefits not provided for by law

A major innovation brought by the practice of collaboration agreements is the granting of benefits not provided for in the Organized Crime Act. ${ }^{185}$

182 Canotilho and Brandão (n 36) 30.

183 Vasconcellos, Colaboração Premiada No Processo Penal (n 36) 19.

184 The list of the analyzed collaboration agreements, as well as the methodology used to identify them, can be found in the Annex of the thesis.

185 Several authors point out that the Brazilian rewarded collaboration is marked by the awarding of benefits that are not provided by law. See Canotilho and Brandão (n 36) 30-35; Bottino (n 36) 7-8. Defending this practice, see Mendonça (n 36). Similarly, the National Strategy to Combat Corruption and Money Laundering (ENCCLA), a body that gathers several Brazilian law enforcement 
The statutory text establishes that offenders may receive, through collaboration agreements, the following benefits: (i) judicial pardon, (ii) reduction by up to two-thirds of an imprisonment sentence, (iii) substitution of an imprisonment sentence for penalties of rights restrictions, (iv) dropping of charges by the Public Prosecution Office and ( $\mathrm{v}$ ) progression between detention regimes.

Although there is no provision in the Organized Crime Act that authorizing the grant of other benefits than these, several collaboration agreements have significantly expanded the types of privilege obtained by cooperating defendants.

Among these new benefits, one is worth highlighting: the design of new forms of detention regimes. ${ }^{186}$ Brazilian criminal legislation provides for three detention regimes: (a) the closed regime, in which the sentence is served in high- or average-security prisons, (b) the semi-open regime, in which the penalty is served in an agricultural or industrial colony, or in a similar institution and (c) the open regime, which is served in a shelter or other appropriate institution. ${ }^{187}$ Each of these regimes imposes different restrictions on the freedom of a convicted person. The initial detention regime is defined by the sentencing judge, depending to a great extent on the length of the imprisonment sentence imposed on the defendant, who, for example, must serve the sentence in the closed regime if he or she is sentenced to more than eight years of imprisonment. ${ }^{188}$

In the Brazilian practice of collaboration agreements, procedural participants have repeatedly designed new detention regimes, with specific characteristics for each cooperating defendant. These new regimes, which have gained denominations such as "differentiated closed regime," 189 "differen-

authorities, approved a guideline defending this practice. According to this position, collaboration agreements can grant benefits not foreseen in the Organized Crime Act "as long as they respect the Constitution, the law, the general principles of law and do not harm good morals and public order". See ENCCLA, 'Manual: Colaboração Premiada' (Brasília, January 2014) <http://www.mpf.mp. br/atuacao-tematica/sci/dados-da-atuacao/eventos-2/eventos-internacionais/conte udo-banners-1/enccla/restrito/manual-colaboracao-premiada-jan14.pdf/view> accessed 4 January 2019, 7.

186 Marcelo Cavali notes that several collaboration agreements established "detention regimes nor provided for by law". See Cavali (n 36) 262. The innovation was endorsed by the Federal Public Prosecution Office in its orientation note on collaboration agreements. See MPF, Joint Orientation Note 1/2018, art 27.

187 Brazilian Criminal Code, art $33 \$ 1$.

188 ibid art $33 \$ 2$ indent "a".

189 See STF, Collaboration Agreeement of J.S.O.M [2016], appendix 1. 
tiated semi-open regime" 190 and "differentiated open regime", ${ }^{191}$ establish completely different rules from those provided for in Brazilian criminal law. Although the details may vary from agreement to agreement, these "differentiated" regimes clearly permit favorable situations not provided under Brazilian criminal legislation. A common feature of the negotiated detention regimes is the possibility for the defendant to serve long imprisonment sentences in their own private residence, an option that is not available under Brazilian criminal legislation. ${ }^{192}$ Another hallmark is the setting of tailor-made regulations for each cooperator, ${ }^{193}$ which gives rise to very detailed and idiosyncratic regulations regarding the conditions of the detention regime.

One agreement, for instance, established a "differentiated closed regime" with the following conditions: i) obligation of the cooperator to serve the imprisonment sentence in his own private residence during the negotiated period; ii) permission to leave, on eight days per year, his residence for a period of six continuous hours; iii) obligation to be constantly monitored through electronic anklets; iv) permission to receive visits from 27 family members and friends included in a list attached to the agreement. ${ }^{194}$ Another agreement created a "differentiated semi-open regime", in which the cooperator was subject to the following restrictions: i) obligation to remain - on business days from 10:00 p.m. to 06:00 a.m., and during the whole day on weekends - in his own private residence; ii) permission to stay, during three days per year, in other location than his residence; iii) obligation to be constantly monitored through electronic anklets; iv) obligation to perform 22 hours per month of community service; v) prohibition of travel, except within Brazilian territory and for work purposes. ${ }^{195} \mathrm{~A}$ third agreement designed a "differentiated open regime" with the following characteristics: i) obligation of the cooperator to remain - on business

190 See STF, Collaboration Agreeement of J.C.S.F. [2017], clause 4 para I item "c.

191 See STF, Collaboration Agreement of R.R.P. [2015], clause 5 item "c".

192 The Brazilian legislation establishes two conditions for the convicted person to be eligible for serving the sentence in their private residence: i) to already be serving an open regime sentence and ii) to fit one of the following categories: a) being more than 70 years old, b) having a serious illness, c) being pregnant, d) being a woman and being mother to a minor or a disabled person.

193 For a defense of an extensive negotiation regarding different types of agreement benefits, considering the specificities of each case, see Fonseca (n 98) 173-174; 212-215.

194 See STF, Collaboration Agreeement of J.S.O.M [2016], appendix 1.

195 See STF, Collaboration Agreeement of J.C.S.F. [2017], clause 4 para I item "c". 
days, from 08:00 p.m. to 06:00 a.m., and during the whole day on weekends - in his own private residence; ii) prohibition of international travel, except for medical purposes; iii) obligation to present bimonthly reports on his professional activities; iv) obligation to perform 30 hours per month of community service. ${ }^{196}$ Several other agreements have also designed "differentiated detention regimes", with tailor-made regulation that set up very specific rules, such as the prohibition of holding parties or social events at the cooperating defendant's house. ${ }^{197}$

Developed in practice by procedural participants, the design of new detention regimes was expressly embraced by the Federal Public Prosecution Office in its orientation note on collaboration agreements, notwithstanding the lack of any statutory provision on the matter. According to the orientation note, "in case of establishment of differentiated detention regimes, the agreement must specify the applicable rules”. 198

In addition to the new detention regimes, the practice of collaboration agreements conceived other innovations in favor of cooperators. An example is the granting of benefits related to personal assets of the defendants. ${ }^{199}$ While the Brazilian legislation generally determines that assets obtained through criminal activities must be confiscated and auctioned, 200 collaboration agreements have created specific regulations regarding the cooperator's assets, although such a possibility is not foreseen by the Organized Crime Act. One agreement ${ }^{201}$ established that the cooperator's family members would be temporarily allowed to keep assets obtained through criminal activities. ${ }^{202}$ In the same case, a property belonging to the cooperator was handed to his ex-wife and another to his daughters, even though it was unclear whether these assets were associated with criminal activities. ${ }^{203}$ It was also decided that, if the cooperation provided by the defen-

196 See JFPR, Collaboration Agreement of P.J.B.F. [2014], clause 5 para III-IV.

197 See STF, Collaboration Agreement of L.B.F. [2017], clause 4 para II item "b" indent "iv".

198 See MPF, Joint Orientation Note 1/2018, art 27.

199 For a discussion concerning the subject, see Pereira, Delação Premiada: Legitimidade e Procedimento (n 104) 151-152.

200 Criminal Code, art. 91, II and Code of Criminal Procedure, arts. 125 e 133.

201 See STF, Collaboration Agreement of A.Y. [2014], clause 7 para 3.

202 Bottino (n 36).

203 See STF, Collaboration Agreement of A.Y. [2014], clause 7 para 5-6. 
dant led to the recovery of illegal assets of a certain value, the cooperator's family would be allowed to retain a commercial real estate property. ${ }^{204}$

Another benefit created in the practice of collaboration agreements is the definition not only of the cooperator's rights and obligations, but also of the legal situation of his or her family members. Although the Organized Crime Act does not mention the possibility for a cooperator to obtain benefits in favor of other individuals, various agreements have provided for conditions regarding family members of a cooperating defendant. In one case, an agreement clause established that the Public Prosecution Office would offer the cooperator's family members individual collaboration agreement proposals with pre-determined benefits. ${ }^{205}$ Another agreement dedicated a whole section to regulating the "legal treatment of family members", in which the cooperator agreed to obtain evidence that was in the possession of his family and, in return, the Public Prosecution Office consented not to open charges against any family member that acceded to the agreement. ${ }^{206}$

\section{ii. Exact definition of imprisonment penalties}

The practice of collaboration agreements has also innovated with respect to the manner in which the penalties imposed on the cooperating defendant are defined. In several cases, agreements outlined the exact penalties to be imposed on the cooperator and the detention regime for serving them, ${ }^{207}$ in a way that is not established in the Organized Crime Act.

204 See STF, Collaboration Agreement of A.Y. [2014], clause 7 para 4. All these transactions were considered valid by the Federal Supreme Court, which decided that "the collaboration agreement can regulate property matters related to the profit obtained by the collaborator through the crimes of which he is accused." See STF, HC 127483 [2015] (Toffoli J). According to the decision, although the traditional rules of Brazilian criminal law determine the seizure of all assets obtained through criminal activities, the United Nations Convention against Transnational Organized Crime (the Palermo Convention) and the United Nations Convention against Corruption (the Merida Convention) recommend the adoption of measures to promote cooperation with offenders, which justifies the concession of that type of benefit.

205 See STF, Collaboration Agreement of P.R.C. [2014], clause 5 para VII-VIII.

206 See STF, Collaboration Agreeement of J.S.O.M [2016], clause 5 para 4.

207 On this subject, Salo de Carvalho notes that the concrete experience regarding agreements, through an "anomalous" use of the rewarded collaboration, is determining "penalties, in quantity and quality". See Carvalho (n 36) 515-516. 
According to the statutory text, when a defendant provides criminal investigations with effective cooperation, courts may grant judicial pardon, reduce the imprisonment sentence by up to two-thirds or substitute an imprisonment sentence for penalties of restriction of rights. The practice of collaboration agreements, however, has created a system of transactions in which defendants and the Public Prosecution Office, rather than negotiating over the benefits provided by law, precisely decide the imposed penalties. ${ }^{208}$ These agreements stipulate not only the length of the imprisonment penalty, but also the detention regimes in which the penalties must be served, specifying exactly the period that the cooperator will spend in each detention regime.

In one case, the agreement established the imprisonment penalty as follows: (i) one hundred and sixty days of imprisonment under closed regime; ${ }^{209}$ (ii) one year and six months of imprisonment under "differentiated closed regime"; (iii) one year and six months of imprisonment under "differentiated semi-open regime"; (iv) one year of imprisonment under "differentiated open regime". ${ }^{210}$ Another agreement provided for the following punishment of the cooperator: (i) two years of imprisonment under closed regime; (ii) two years of imprisonment under "differentiated closed regime"; (iii) two years of imprisonment under "differentiated semiopen regime"; (iv) two years of imprisonment under "differentiated open regime"; (e) four years of community service, with a workload of 7 hours per week; (vi) six years of study in courses defined in accordance with the

Marcelo Cavali also observes this trend, highlighting its similarity to the U.S. system of plea bargaining. See Cavali (n 36) 262.

208 From the analysis of some agreements, Guilherme de Oliveira Alonso concludes that this practice is characterized by the determination, through agreements concluded in initial stages of the procedure, of a maximum penalty for the collaborator, with the definition of a regime for the immediate serving of the sentence. See Guilherme de Oliveira Alonso, 'A Colaboração Premiada e o Princípio "Nulla Poena Sine Judicio"' (2018) XIV Revista Magister de Direito Penal e Processual Penal 71, 89. Gustavo Badaró emphasizes, in a critical way, the concentration of attributions brought by this model of negotiation, noting that collaboration agreements are serving, at the same time, to investigate, establish the truth, define the cooperator's penalty and to effectively punish them. See Badaró (n 173) 143.

209 In this case, considering that the defendant was already in custody under in pretrial detention, the agreement determined that the extent of the sentence he would have to serve in closed regime should be decreased by the period he was detained under preventive detention. See STF, Collaboration Agreeement of J.C.S.F. [2017], clause 4 I.

210 See STF, Collaboration Agreeement of J.C.S.F. [2017], clause 4. 
Federal Public Prosecution Office, with a total course load of 200 hours per year. ${ }^{211} \mathrm{~A}$ third agreement established the criminal punishment of the cooperator in the following manner: (i) one year and six months of imprisonment under "differentiated closed regime"; (ii) three years of imprisonment under "differentiated semi-open regime"; (iii) three years of imprisonment under "differentiated open regime"; (iv) payment of fine of almost 10.5 million Brazilian reals; (v) during the period of imprisonment penalty, the removal of any position in corporations that have contracts with the public sector; (vi) prohibition of maintaining contact with public agents during the period of imprisonment penalty; (vii) prohibition of contracting with the public sector during the period of imprisonment penalty; (viii) the duty to attend to courses of professional ethics, with a total course load of 40 hours per year, during the period of imprisonment under the differentiated semi-open and open regimes. ${ }^{212}$

Thus, instead of applying the specific benefits provided by law, several agreements have directly determined the cooperator's criminal punishment and detailed how it should be fulfilled. ${ }^{213}$ On several occasions, this has occurred at very early stages of the criminal investigation, even before the Public Prosecution Office had presented any formal indictment against the cooperating defendant. ${ }^{214}$ Even though the Organized Crime Act does not provide for this type of arrangement, this negotiation method was explicitly regulated by the Federal Public Prosecution Office in its orientation note on collaboration agreements: according to the document, the cooperator's benefit should preferably be determined through the establishment of the exact imprisonment penalty and the definition of the appropriate detention regimes. ${ }^{215}$

iii. Package deals and "unified punishment"

Another development brought about by the practice of collaboration agreements is the negotiation of "package deals", through which the coop-

211 See STF, Collaboration Agreement of L.B.F. [2017], clause 4.

212 See STF, Collaboration Agreement of B.B.S.J. [2016], clause 4.

213 See e.g. STF, Collaboration Agreement of Z.S. [2016], clause 5; STF, Collaboration Agreement of R.S.A [2017], clause 4; STF, Collaboration Agreement of F.A.F.S. [2015], clause 5; STF, Collaboration Agreement of A.P.F. [2017], clause 4; and Collaboration Agreement of C.R.R. [2017], clause 4.

214 As noted by Cavali: Cavali (n 36) 265.

215 See MPF, Joint Orientation Note 1/2018, art 26.1.b. 
erator confesses simultaneously to several crimes and receives a single penalty for all his offenses. ${ }^{216}$ The Organized Crime Act provides that courts may grant judicial pardon or reductions of the imprisonment sentence by up to two thirds for cooperating defendants. According to this textual provision, the granting of benefits depends on the prior assessment of each wrongdoing committed by a cooperating defendant and on the determination of the adequate sentence. After determining the sentence, courts may apply the benefits of the rewarded collaboration regulation, reducing the penalties or granting pardon for each of the convictions.

In judicial practice, however, a very different type of arrangement has emerged. In various cases, parties have signed agreements which established a unified single penalty that encompassed all the practices described in the defendant's cooperating report or that were somehow related to the reported crimes. ${ }^{217}$ In this model of negotiation, the negotiation unfolds not by defining the illegal acts committed by the cooperator, assigning to each of these acts the appropriate punishment and granting afterwards the benefits provided for by the Organized Crime Act. It rather unfolds by determining a single encompassing penalty for a series of acts reported by the offender.

The "unified" penalty covers not only a wide range of wrongdoings, but also encompasses different criminal proceedings. ${ }^{218}$ One collaboration agreement, for instance, established that the cooperating defendant should be sentenced "to a maximum penalty of twenty years of imprisonment, considering for this end the unification of the penalties set in the existent criminal proceedings and in the proceedings that will be opened based on this agreement". ${ }^{219}$ Another agreement fixed a maximum penalty of eighteen years of imprisonment "in the aforementioned criminal proceedings, in those already existent and in those that will be opened to investigate the facts revealed through this cooperation, as well as the facts narrated in the appendixes that are part of this agreement and the facts exposed in depositions that exceed the scope of the appendixes."220

216 For a good description of this practice, see Mendonça (n 36) 89-91.

217 See JFPR, Collaboration Agreement of A.R.M.N. [2014], clauses 3-5; JFPR, Collaboration Agreement of C.A.P.C. [2016], clauses 3-4; STF, Collaboration Agreement of C.R.R. [2017], clauses 3-4; JFPR, Collaboration Agreement of E.H.L. [2015], clauses 3-5; STF, Collaboration Agreement of F.M.S. [2017], clauses 4-5.

218 Criticizing the purported wide reach of collaboration agreements, see: Canotilho and Brandão (n 36) 27-28.

219 STF, Collaboration Agreement of A.C.O.R. [2016], clause 5 para 1 item "a".

220 STF, Collaboration Agreement of R.R.P. [2015], clause 5. 
Various agreements contain clauses that show the wide reach of the unified punishment negotiated by the parties. On agreement stipulated, for example, that "this agreement encompasses all illegal acts practiced by the cooperator up to the date of signature, as well as all illegal acts that are of his knowledge, which are described in the appendixes that are part of this agreement." 221 Another agreement specified that its scope comprised "the facts analyzed in the investigative proceedings listed in this agreement and in the following appendixes, in addition to all proceedings that will be opened based on them or that are related to them, as well as facts that are still not under investigation but that are of the cooperator's knowledge and will be the object of future questioning". ${ }^{222}$ In one case, an agreement stipulated that even wrongdoings investigated in criminal proceedings that would be opened before other courts would be encompassed by the scope of the arrangement and its unified punishment. ${ }^{223}$

In this system of far-reaching and fully encompassing transactions, the legal qualification of the wrongdoings confessed by the cooperating defendant is usually described in broad terms. One agreement provided that the arrangement covered "crimes against the financial system, corruption, embezzlement, money laundering and criminal organization”. ${ }^{224}$ Another agreement established a unified penalty for acts involving "the practice of various crimes, especially corruption, money laundering, and criminal organization, as well as the illegal transacting of tens of millions of dollars." 225 In one case, a collaboration agreement fixed a unified penalty for "unlawful acts that include, among others, the following kinds of offenses: criminal organization, active bribery, passive bribery, money laundering, bidding fraud, formation of cartel, misrepresentation, tax crimes, and capital flight."226

In this manner, a kind of package deal was created: the cooperating defendant reports a series of unlawful acts, which are investigated or could lead to several different criminal procedures and, instead of receiving specific benefits in each of these procedures - as established by the Organized Crime Act - he or she receives a unified penalty. From a system of benefits based on a specific assessment of each criminal act as provided by the Or-

221 STF, Collaboration Agreement of D.Q.G.F. [2017], clause 3.

222 STF, Collaboration Agreement of S.C.B. [2017], clause 1 para 1.

223 See STF, Collaboration Agreeement of J.S.O.M [2016], clause 4 para 1.

224 STF, Collaboration Agreement of R.R.P. [2015], clause 4.

225 See JFPR, Collaboration Agreement of P.J.B.F. [2014], clause 4 para 1.

226 See STF, Collaboration Agreeement of J.S.O.M [2016], clause 4 para 1 and clause 5 para 1. 
ganized Crime Act, the practice of collaboration agreements eventually evolved towards a model of negotiation that permits a cooperating defendant to solve simultaneously all the criminal charges he or she faces or could face. This type of negotiation, which clearly leads to more generous benefits than those provided for in the Organized Crime Act, has been defended as a practical need to design an attractive and secure option for cooperating defendants. ${ }^{227}$ Despite the lack of statutory basis, the innovation was regulated by the Federal Public Prosecution Office in its orientation note on collaboration agreements, which recommends that collaboration agreements may establish "a unified punishment for the amount of facts". 228

iv. The serving of imprisonment penalties in advance

A final important innovation in the Brazilian practice of rewarded collaboration was the provision that the cooperator may serve the negotiated imprisonment penalties at early stages of the criminal investigation, before the court pronounces the verdict and sentence. ${ }^{229}$ Several agreements established that the cooperating defendant would start serving the imprisonment penalties immediately upon the conclusion of the deal and its ho-

227 In this regard, Andrey Borges de Mendonça argues that: "As has been seen in practice, revealed by investigations on corruption in recent years, it is quite common for a single agent to report 30 or more crimes. In this situation, offering the cooperator a sentence reduction, in a range between one and two thirds, would not be of interest to either party. For the defendant, because a decrease of this amount in each of the reported crimes would lead to a final penalty that is still excessive. Imagine if the offender were to be convicted, in each of the 30 crimes that he reports, to five years imprisonment for each of them. Summing the sentences, the final sentence could come to 150 years. If the penalty were reduced by two-thirds - the maximum in law - it would still be excessively high, with the offender having to serve 50 years in prison! Accepting a generic benefit under such circumstances can be extremely prejudicial to the cooperator, in addition to leaving him in a situation of absolute uncertainty, due to not knowing beforehand which potential penalty he will have to serve in the end". See Mendonça (n 36) 89.

228 See MPF, Joint Orientation Note 1/2018, art. 27 and 26.1.a.

229 Marcelo Cavali describes this innovation: "Several concluded agreements have established sanctions - including prison regimes not provided for in the law to be faced by the cooperators, without even the need for a conviction". See Cavali (n 36) 262. Vasconcellos also noticed the practice: Vasconcellos (n 36) 115 . 
mologation by the court, regardless of any judicial decision affirming the defendant's guilt. ${ }^{230}$ Others enabled the cooperator to seek judicial permission to serve the imprisonment penalties "beforehand", prior to the end of the criminal proceeding. ${ }^{231}$

The possibility that the cooperator serves in advance the negotiated imprisonment punishment constitutes a clear innovation in Brazilian law, as it creates a situation in which the individual may serve imprisonment penalties before being convicted by a judicial body. ${ }^{232}$ This situation is completely new to Brazilian law, since the traditional rules of criminal procedure establish that the imposition of an imprisonment penalty can only be made after the completion of the full-blown criminal process. ${ }^{233}$ The defendant's confession does not end the official investigation, which must continue even when the accused has admitted culpability for the wrongdoing. ${ }^{234}$ According to the Brazilian Code of Criminal Procedure, a defendant's confession must be analyzed together with all other evidence collected by judicial bodies, who must confirm their consistency. ${ }^{235}$ Defendants may at any time withdraw their confession, and courts are free to reach a decision analyzing the complete body of evidence. ${ }^{236}$

Contrary to these standard rules, and based primarily on the confession and on the evidence presented by the cooperator, the practice of collaboration agreements allowed defendants to serve imprisonment sentences at very early stages of the criminal investigation. In some occasions, in which the collaboration agreement was signed before the charges were pressed, the authorization for the early serving of penalties was granted even before

230 In this regard, see STF, Collaboration Agreeement of H.M.A.S.F. [2017], clause 4 para II, providing that "the imprisonment penalty will be served right after the homologation of this agreement". See also JFPR, Collaboration Agreeement of D.S.A [2015], clause 5 para IV, establishing that the serving of the imprisonment penalties will start "from the moment of the signature of this agreement". Furthermore, see STF, Collaboration Agreeement of I.U.C.S. [2017], clause 4, item ii; STF, Collaboration Agreement of D.A.G. [2016], clause 13; STF, Collaboration Agreement of B.B.S.J. [2016], clause 4 item ii; STF, Collaboration Agreement of M.B.O. [2017], clause 4 item ii.

231 See STF, Collaboration Agreeement of J.S.O.M [2016], clause 5 para 1 item "e".

232 As noted by Alonso (n 208) 90. Very emphatically, Badaró criticizes situations in which, through collaboration agreements, individuals serve penalties without having been formally investigated. See Badaró (n 173) 143.

233 See section I.1.

234 Brazilian Code of Criminal Procedure, art 158.

235 ibid art 197.

236 ibid art 200. 
the formal start of a criminal proceeding against the cooperating defendant. ${ }^{237}$

This situation differs from the consensual solutions designed by the 1995 Small Claims Act, which can not define imprisonment punishment and may impose only sanctions of restriction of rights and fines. ${ }^{238}$ There is also another important difference: unlike the consensual solutions of the Small Claims Act, which put an end to the official investigation of the facts after the conclusion of an arrangement between the parties, the signing of a collaboration agreement does not lead to the termination or the suspension of the criminal proceeding. According to the Organized Crime Act, the guilt of all the accused, including the cooperator, will be determined by a judicial decision issued at the end of the criminal proceeding, and no guilty verdict shall be based only on the statements of the cooperator. ${ }^{239}$

Thus, the practice of the anticipatory serving of imprisonment penalties, as designed in various collaboration agreements, may lead to a scenario in which the cooperator serves voluntarily a sanction of imprisonment and, at the end of the proceeding, is acquitted. In other words, these provisions contain the implicit recognition that the cooperator can be acquitted after signing the collaboration agreement and serving the penalty. ${ }^{240}$ Because of this possibility, some collaboration agreements exempted the state of any liability in the event that the cooperator, after serving the imprisonment penalties in advance, is acquitted at the end of the process or that the sentence imposes lower penalties than the ones established in the agreement. ${ }^{241}$ This exemption clause is also an original development, since the Brazilian Constitution expressly establishes the right of compensation to individuals who have been imprisoned for longer than the period established in the sentence. ${ }^{242}$

237 See e.g. STF, Collaboration Agreeement of J.S.O.M [2016].

238 Brazilian Small Claims Act 1995, art 76.

239 Brazilian Organized Crime Act 2013, art $4 \$ 11$ and $\$ 16$.

240 As noted by Vasconcellos (n 36) 115.

241 See STF, Collaboration Agreeement of J.S.O.M [2016], clause 5 para 1 item "e".

242 Brazilian Federal Constitution, art 5 LXXV. 
b. Contractual freedom, tailor-made arrangements and unique consensual solutions

From the reading of the collaboration agreements, it is clear that legal practitioners used the system of "quid-pro-quo" negotiations established by the Organized Crime Act to develop an elastic model of transactions. ${ }^{243}$ Collaboration agreements concluded in the last years are drafted over several pages, contain dozens of clauses and regulate a wide range of aspects of the criminal procedure. The tailor-made approach adopted in the drafting of these agreements enabled the parties to design innovative and creative solutions, ${ }^{244}$ customized for the specific situation of each case. ${ }^{245}$

This system of tailor-made negotiations generated unique - and quite peculiar - contractual provisions. One collaboration agreement, for instance, designed a sort of "success fee" for the cooperator, stipulating that two percent of the value of the illegal assets recovered with his assistance would be written off his compensation fine. ${ }^{246}$ Another agreement created a right to "penalty equalization", establishing that, if other defendants from the same company negotiated a collaboration agreement with lower imprisonment penalties, the cooperator's punishment would be equalized, so that his legal situation would not be less favorable. ${ }^{247}$ According to the provision, in these circumstances the cooperator and the Federal Public Prosecution Office should negotiate an amendment to the original agreement and submit it to the competent judicial body. ${ }^{248}$

243 It is interesting to note that the phenomenon observed in the criminal law experience has no matching example in the antitrust sphere. Although there isn't a specific analysis of the subject, the greater rigidity of the antitrust leniency mod$\mathrm{el}$ - in the form of the winner-takes-it-all model - presents itself as an important factor to understand such a discrepancy. For a more detailed comparison of the practice of both leniency programs, see Chapter VI.

244 In this aspect, the Brazilian practice of collaboration agreements resembles the U.S. system of plea bargaining, where the prosecutors "bring the same spirit of inventiveness to their task that American business lawyers bring to the drafting of contracts”. See James Whitman, 'No Right Answer' in John Jackson, Máximo Langer and Peter Tillers (eds), Crime, procedure and evidence in a comparative and international context: essays in honour of professor Mirjan Damaska (Hart Publishing 2008) 387.

245 For a defense of this practice, see Fonseca, to whom the collaboration agreements concluded recently "are, in fact, bringing more benefits than costs to society". See Fonseca (n 98) 212-215.

246 See STF, Collaboration Agreement of A.Y. [2014], clause 7 para 4.

247 See STF, Collaboration Agreement of F.M.S. [2017], clause 5 para 4

248 See STF, Collaboration Agreement of F.M.S. [2017], clause 5 para 5. 
Many agreements designed singular rights for cooperating defendants during the serving of imprisonment penalties in the so-called "differentiated regimes". Amongst several cases, some provisions of various agreements are illustrative, such as the permission to travel on two weekends per month to three specific cities in Brazil ${ }^{249}$ the possibility for the cooperator to obtain a special visit approval, in case his mother faces health problems that demand medical intervention; ${ }^{250}$ and the authorization to spend three days per month in the cooperator's agricultural property for work purposes. ${ }^{251}$ Other agreements established a type of vacation time: after each period of twelve months serving an imprisonment sentence under a "differentiated regime", cooperators acquired the right to spend some days outside their own residence. ${ }^{252}$ The consensual definition of detention regimes has been so meticulous that in one case the collaboration agreement specifically authorized the cooperator to leave his residence, for a continuous period of six hours, to celebrate of Father's Day at his children's school. ${ }^{253}$

The uniqueness of each collaboration agreement can also be observed in the definition of the payment conditions for the monetary fines established in the consensual arrangements. One agreement established that the cooperator could pay the negotiated fine after he succeeded in selling his real estate properties located in Miami. ${ }^{254}$ Another agreement authorized the cooperator to pay the fine within one year as long as he presented a bank letter of guarantee with credit rating "AAA" or "AA+" given by an international credit rating agency. ${ }^{255}$

Besides establishing unique rights, collaboration agreements also designed new kinds of duties for cooperators, according to the specific circumstances of each individual. One agreement established the duty for the cooperating defendant to collaborate, over a period of thirty years, "with the production of studies, analyses, counseling activities in favor of the Federal Public Prosecution Office and the Federal Police". ${ }^{256}$ In another

249 See STF, Collaboration Agreement of D.A.G. [2016], clause 13 para 8.

250 See STF, Collaboration Agreeement of J.S.O.M [2016], appendix 2 clause 4.

251 See STF, Collaboration Agreeement of H.M.A.S.F. [2017], clause para 3 item "c" indent "ii".

252 See STF, Collaboration Agreement of B.B.S.J. [2016], clause 4 para II item b indent "ii". Also: STF, Collaboration Agreeement of I.U.C.S. [2017], clause 4, para II item b indent "ii".

253 STF, Collaboration Agreement of F.A.F.S. [2015], appendix 1 clause 1 para 1.

254 STF, Collaboration Agreement of A.C.O.R. [2016], clause 5 para 3 item "iii".

255 See STF, Collaboration Agreement of B.B.S.J. [2016], clause 4 para III item "a".

256 See STF, Collaboration Agreement of L.B.F. [2017], clause 4, para II, item "g". 
case, the cooperator was prohibited from having contact with public agents and political representatives and from providing marketing services for election campaigns during the penatly period. ${ }^{257}$ In some situations, cooperating defendants agreed to attend courses of ethics, integrity and compliance with a total workload of forty hours per year. ${ }^{258}$ Collaboration agreements also forbade cooperators from going to bars, gambling spots and prostitution houses. ${ }^{259}$

The system of tailor-made transactions also led to the creation of innovative clauses regarding the conduct of public prosecutors. One agreement established that, due to the cooperative behavior of the defendant, the Brazilian Federal Public Prosecution Office would try to convince foreign authorities, particularly from the United States and Switzerland, not to press charges against the defendant. ${ }^{260}$ Another agreement stipulated that the cooperating defendant would forfeit financial assets housed abroad and transfer them directly to a bank account of the Judiciary or the Federal Prosecution Office, for the purpose of future use in activities related to the prosecution of money laundering. ${ }^{261} \mathrm{~A}$ third one authorized the Federal Public Prosecution Office to request, based on the effectiveness of the assistance provided by the cooperator, the progression of the detention regime after the cooperator had served over half of the imprisonment penalty. ${ }^{262}$

The assessment of collaboration agreements indicates, therefore, an environment of broad contractual freedom, in which the parties negotiate unrestrictedly over a large set of issues. In this context, collaboration agreements provided for unique and peculiar clauses, geared to address the particular interests of the cooperator and public prosecutors. The analysis of agreements concluded between cooperating defendants and Public Prosecution Office reveals an abundance of specific and detailed clauses, creating an original set of rights and obligations for each situation.

257 See STF, Collaboration Agreeement of J.C.S.F. [2017], clause 4 para V and VII.

258 See STF, Collaboration Agreeement of H.M.A.S.F. [2017], clause 4 para VIII; and STF, Collaboration Agreement of M.B.O. [2017], clause 4, para VIII.

259 See JFPR, Collaboration Agreement of C.A.P.C. [2016], clause 4 para II item "c"; STF, Collaboration Agreement of A.P.C.S.D. [2016], appendix 2, clause V; STF, Collaboration Agreement of E.N.A.J. [2016], appendix 3 clause III.

260 See JFPR, Collaboration Agreement of A.M.C. [2015], clause 5 para 4.

261 See JFPR, Collaboration Agreement of A.A.C.B. [2014], clause 7.

262 See STF, Collaboration Agreement of M.B.O. [2017], clause 4, para II item "b" indent "vi". 
c. A new model of criminal procedure? Collaboration agreements and consensual criminal justice

Over recent years, the inventive practice of collaboration agreements has received solid support from the Federal Public Prosecution Office and from the Brazilian judiciary, particularly from Brazilian higher courts. Since 2014, defendants have negotiated with the Federal Public Prosecution Office, particularly in criminal investigations related to corruption practices and corporate wrongdoings, several hundred collaboration agreements, which have been validated by judicial bodies.

The Federal Public Prosecution Office has fully embraced this flexible and comprehensive model of negotiation. Since the enactment of the Organized Crime Act, it has negotiated and concluded hundreds of collaboration agreements that contain a wide range of innovations and decide on matters that go far beyond those regulated in the statutory provisions. In 2018 , it also enacted a formal orientation note supporting the innovations brought about through legal practice. ${ }^{263}$ The Brazilian judiciary has also played an important role in the development of this ingenious and elastic system of transactions. According to the Organized Crime Act, as soon as the parties reach a common understanding, the collaboration agreement must be submitted to a court and only becomes valid after the judicial body verifies its regularity. ${ }^{264}$ Besides the repeated validation of innovative collaboration agreements, Brazilian courts have, in paradigmatic decisions regarding the limits of the rewarded collaboration regulation, affirmed the legality of the consensual innovations developed by cooperators and the Public Prosecution Office, repeatedly rejecting judicial remedies and petitions presented by other defendants. ${ }^{265}$

Judicial support was essential for the expansion of the room for negotiation designed by the Organized Crime Act and enabled the development of a broad and flexible system of negotiation. The endorsement of the innovative practice of collaboration agreements is frequently based on the concept that the Organized Crime Act has fostered a new model of criminal justice, different from the traditional system of the Brazilian criminal

263 See MPF, Joint Orientation Note 1/2018.

264 Brazilian Organized Crime Act 2013, art 4 \$7. See section I.3.

265 See item I.4.c.ii. For an overview of the case law of the Brazilian Supreme Court regarding collaboration agreements, see André Callegari and Raul Linhares, Colaboração premiada: lições práticas e teóricas de acordo com a jurisprudência do Supremo Tribunal Federal (Livraria do Advogado 2019). 
procedure. In an important case decided by the Federal Supreme Court, a Justice's opinion affirmed that the rewarded collaboration is part of "a new paradigm of criminal justice, in which the central element is the consent of the participants of the criminal procedure". ${ }^{266}$ According to this opinion: ${ }^{267}$

The legislative regulation of the institute of rewarded collaboration has brought a significant transformation of the criminal scene in Brazil, creating means intended to legitimize and forge, legally, a new model of criminal justice that favors the expansion of the space of consensus and the adoption, in the definition of controversies arising from criminal offenses, of solutions based on the consent of the agents who are parties of the criminal procedural.

Other judicial decisions adopted a similar position and correlated the practice of collaboration agreements with the ideal of a new model of criminal justice, in which procedural participants would have broad scope to consensually decide on diverse aspects of criminal proceedings. On multiple occasions, the Federal Public Prosecution Office adopted an analogous stance, stating that collaboration agreements integrate a "system of consensual justice" and should be interpreted according to the "principle of the consensual due process of law". ${ }^{268}$

The practice of collaboration agreements has also gained support in legal scholarship, ${ }^{269}$ with some authors arguing that the "rewarded collaboration regulation imposes a reflection on a new model of criminal justice, based on consensus". ${ }^{270}$ According to this view, the rewarded collaboration regulation, provided for by the Organized Crime Act, gave rise to new

266 STF, PET 7074 [2017] (Celso de Mello J).

267 STF, PET 7074 [2017] (Celso de Mello J).

268 See also the allegations of the Federal Public Prosecution Office in the following proceedings: STF, PET 7265 [2017] and STF, PET 5779 [2015].

269 For a general defense of the practice of collaboration agreements, see Mendonça (n 36). Also favourably: Fonseca (n 98) 212-215. Different practices are defended in specific articles: Alonso (n 208); Douglas Fischer, 'Em Busca Da Aplicação Correta e Justa Das Penas Perdidas: O Caos Decorrentes de Um Sistema Anacrônico e Repetitivo de "Precedentes-Ementas" in Américo Bedê Júnior and Gabriel Silveira de Queirós Campos (eds), Sentença criminal e aplicação da pena: ensaios sobre discricionariedade, individualização e proporcionalidade (Juspodivm 2017) 195. Presenting a contrary view: Canotilho and Brandão (n 36); Badaró (n 173); Bottino (n 36).

270 Mendonça (n 36) 7. 
paradigm in Brazilian criminal law, ${ }^{271}$ one based on a contractual system between procedural participants. ${ }^{272}$ This model should be interpreted as having its own operating form, grounded on the principles of individual autonomy, efficiency, honesty and good faith. ${ }^{273}$ Another principle commonly indicated as paramount for the proper functioning of collaboration agreements is the protection of legitimate expectations and legal certainty, ${ }^{274}$ leading to the application of the "venire contra factum proprium" doctrine, ${ }^{275}$ which prevents a party from adopting a behavior that contradicts previous acts on which the co-contracting agent has relied. ${ }^{276}$

The expansion of the scope for negotiation in collaboration agreements is also often based on the experience of other countries with consensual mechanisms in criminal justice, particularly the U.S. model of plea bargaining. ${ }^{277}$ In one of the first judicial decisions to accept the practice of

271 Márcio Adriano Anselmo, 'Colaboração Premiada Como Novo Paradigma Do Processo Penal Brasileiro', Estudos em homenagem ao professor Sérgio Moro (Instituto Memória Editora 2017).

272 Castro (n 89).

273 Mendonça (n 36).

274 For a strong argument in this respect, see Sarmento (n 35) 464-468.

275 Alexandre Morais da Rosa, 'A Aplicação Da Pena Na Justiça Negocia: A Questão Da Vinculação Do Juiz Aos Temos Da Delação', Sentença criminal e aplicação da pena: ensaios sobre discricionariedade, individualização e proporcionalidade (Juspodivm 2017) 72.

276 The "venire contra factum proprium" doctrine is a classic principle of Roman private law and is still mentioned in various legal debates today, especially in relation to questions of abuse of rights. See Bénédicte Fauvarque-Cosson and others, European Contract Law: Materials for a Common Frame of Reference: Terminology, Guiding Principles, Model Rules. See: Bénédicte Fauvarque-Cosson and Denis Mazeaud (Sellier European Law Publishers 2009); Antonio Gambaro, 'Abuse of Rights in Civil Law Tradition' (1995) 3 European Review of Private Law 561. For a German perspective, see: Hans Josef Wieling, 'Venire Contra Factum Proprium Und Verschulden Gegen Sich Selbst' (1976) 176 Archiv für die civilistische Praxis 334.

277 There are frequent references in Brazilian legal literature to the practices implemented in the United States and Italy. See Márcio Barra Lima, 'A Colaboração Premiada Como Instrumento Constitucionalmente Legítimo de Auxílio à Atividade Estatal de Persecução Criminal' in Bruno Calabrich, Douglas Fischer and Eduardo Pelella (eds), Garantismo penal integral: questões penais e processuais, criminalidade moderna e a aplicação do modelo garantista no Brasil (Juspodivm 2013); Antonio Sergio Peixoto Marques, 'A Colaboração Premiada: Um Braço Da Justiça Penal Negociada' (2014) 10 Revista Magister de Direito Penal e Processual Penal 32. For a critical opinion on the attempt to bring rewarded collaboration close to the U.S. system of plea bargaining, see: Badaró (n 173); Cavali (n 36); Canotilho and Brandão (n 36). 
flexible negotiations between cooperating defendants and law enforcement authorities, it was stated that the innovations created in such agreements were legitimate, "either by the incorporation of models of comparative law, where the matter is effectively treated as a negotiation of the right of action, or because the results of more extensive agreements permit better protection of the cooperator and the achievement of justice". ${ }^{278}$ The influence of the experience of countries integrated into the common law tradition is often cited to justify the consensual innovations developed by legal practitioners through collaboration agreements. ${ }^{279}$

In this scenario of strong support both from public prosecutors and judicial bodies, the introduction of the 2013 rewarded collaboration regulation unveiled a comprehensive and flexible model of transactions, in which the parties' room for negotiation is not strictly limited by statutory provisions and can be expanded through tailor-made transactions. The notion that collaboration agreements are part of a distinct system of criminal justice, in which parties can resolve different matters through consensual arrangements, informed two recent developments in Brazilian case-law regarding the employment of these mechanisms.

The first concerns the understanding that collaboration agreements concluded by cooperators and public prosecutors at early stages of criminal investigations have a binding effect on judicial decisions at the sentencing stage, assuring that courts abide by the arrangements negotiated by the contracting parties. The second refers to the concept that collaboration agreements are legal transactions that create obligations and rights only for the contracting agents (cooperator and Public Prosecution Office) and do not affect third parties, a position that prevents other accused from questioning before a court the legality of collaboration agreements.

278 TRF4, COR PAR 035046-4 [2009].

279 On this point, a 2017 report of the Federal Public Prosecution Office affirmed: "All this legal framework, which intensifies and favors a consensual environment, brings innovations that also affect the way in which state prosecution operates and imposes a new comprehension of the legal order, to adapt it to new paradigms, adopted by the influence of the common law systems of the AngloSaxon law". See Ministério Público Federal, 'Estudo Técnico no 01/2017' (Brasília 2017) <http://www.mpf.mp.br/atuacao-tematica/ccr5/coordenacao/grup os-de-trabalho/comissao-leniencia-colaboracao-premiada/docs/Estudo Tecnico 0 1-2017.pdf $>$ accessed 30 May 2019, 34. 
i. The binding effect of collaboration agreements: pacta sunt servanda in criminal procedure

One of the main innovations in the Brazilian practice of rewarded collaboration was the adoption of a negotiation model in which the defendant, through the conclusion of a single agreement at an early stage of the criminal investigation, can obtain a precise and unified penalty that encompasses various offenses described in the cooperation report. In this type of arrangement, the cooperator and the Public Prosecution Office precisely establish, through a written agreement, the imprisonment penalties - including the detention regimes - for all criminal charges faced by the cooperator.

Although this model of transaction is not provided for in the text of the Organized Crime Act, Brazilian courts have repeatedly validated it, providing decisive support for the practice of collaboration agreements by understanding that these arrangements have a binding effect upon judicial bodies. ${ }^{280}$ This position created a secure negotiation environment for cooperators and public prosecutors, who could be confident that the tailor-made agreements - with their ingenious solutions and innovative provisions would be honored in the future by the courts responsible for deciding on the verdict and the sentence of the cooperator. The judicial reasoning on this matter closely resembles the contract law principle of "pacta sunt servanda", according to which a consensual arrangement is "the law of the parties", 281 who are bound to comply with the contractual duties once the other contracting party fulfils his obligation. ${ }^{282}$

In this regard, the Federal Supreme Court has ruled, in one of its central decisions on the matter, that

"the principles of legal certainty and the protection of trust render indeclinable the State's duty to honor the commitment assumed in the collaboration agreement, granting the negotiated benefits and the stipulated penalty, as a legitimate consideration for the performance of the cooperator's obligation". ${ }^{283}$

280 See STF, HC 127483 [2015] and STF, PET 7074 [2017].

281 Fauvarque-Cosson and others (n 276) 461.

282 Basil S Markesinis, Hannes Unberath and Angus Johnston, The German Law of Contract: A Comparative Treatise (2nd edn, Hart Publishing 2006) 263.

283 STF, HC 127483 [2015]. 
According to this decision, if the cooperative behavior produces effective results, the cooperator has a subjective right to the benefits established in the agreement and may demand judicially the fulfillment of the state's obligation. $^{284}$

Similarly, in an opinion issued on another relevant case analyzed by the Federal Supreme Court, it was affirmed that "the competent judicial body, in the final judgment of the criminal case, must respect what has been established in the agreement, once the cooperating agent has complied with the terms defined in the legal transaction". ${ }^{285}$ On the same occasion, it was affirmed that the content of the collaboration agreement is an issue to be decided consensually between the defendant and the law enforcement authorities, while the judiciary must not intrude in the parties' legitimate choices. $^{286}$ The final decision of the Federal Supreme Court on the matter affirmed that "the subjective right of the cooperating defendant arises insofar as he fulfills his duties" and that "the agreement homologated as regular, voluntary and legal engenders a binding effect, that is conditional on the fulfillment of the duties assumed by the cooperating defendant" ${ }^{287}$

This position has also gained wide support in legal scholarship. In this regard, it has been stated that failure to grant the benefits established in the agreement would be unfair conduct from the state, in view of the cooperative behavior adopted by the defendant. ${ }^{288}$ According to this view, once the obligations assumed by the offender are fulfilled, the court is

284 ibid.

285 STF, PET 7074 [2017] (Celso de Mello J).

286 STF, PET 7074 [2017] (Moraes J).

287 See the summary of the decision released by the Brazilian Federal Supreme Court: STF, 'Informativo 870' (June 2017) <http://www.stf.jus.br/arquivo/infor mativo/documento/informativo870.htm $>$ accessed 30 May 2019, 34.

STF, Info 870, Brasília, 19 a 30 de junho de 2017 № 870, Data de divulgação: 7 de julho de 2017

288 From the analysis of the Federal Supreme Court's case law, Pierpaolo Bottini argues that, in the field of rewarded collaboration, the judge's remit is limited to assessing the "effectiveness" of the assistance offered by the collaborator, and that, once the agreement is fulfilled, the collaborator has a subjective right to the benefits. See Pierpaolo Cruz Bottini, 'A Homologação e a Sentença Na Colaboração Premiada Na Ótica Do STF' in Maria Thereza de Assis Moura and Pierpaolo Cruz Bottini (eds), Colaboração premiada (Revista dos Tribunais 2017) 194-195. In the same vein: Renato Brasileiro de Lima, Legislação Criminal Especial Comentada (Juspodivm 2016) 735. 
obliged to grant the agreed benefits, ${ }^{289}$ otherwise there would be no legal certainty in the transaction. ${ }^{290}$ In the scope of negotiated justice, the definition of the agreement's content should be left solely to the parties, while the judge should respect in full the terms of the negotiation. ${ }^{291}$

ii. The principle of "res inter alios acta" and the prohibition of legal challenges by third parties

Another jurisprudential development of great significance for the practice of rewarded collaboration was the understanding that collaboration agreements are legal transactions concluded by the cooperator and the law enforcement authorities, which do not affect third parties. According to this position, the effects of collaboration agreements are restricted to the legal spheres of the signatory parties, and only they have the right to challenge before a court the legality of a collaboration agreement. Based on this argument, Brazilian courts have repeatedly declined to examine judicial appeals presented by other defendants, accused of committing crimes by the cooperator, that challenged some aspects of collaboration agreements. ${ }^{292}$

In one of the main decisions on the subject, ${ }^{293}$ the Federal Supreme Court affirmed that "the collaboration agreement, as a legal transaction of a personal nature, does not bind a defendant accused by the cooperator and does not directly affect his legal sphere: res inter alios acta". ${ }^{294}$ For

289 Douglas Fischer claims that the possibility of the judge analyzing the intensity of the benefits offered to the collaborator, in a collaboration agreement, is "absolutely impertinent, inappropriate and contrary to the legal system". According to the author, only if the collaborator provides assistance that is inferior to what was stipulated by the agreement, can the judge reduce the agreed benefits. See Fischer (n 269) 194-195.

290 Cleber Masson and Vinícius Marçal state that, in case the collaborator fulfills all the negotiated obligations, the judge is bound by the terms of the agreement, "because, otherwise, 'the notion of cooperative procedure would be empty and there would be an undesirable atmosphere of legal uncertainty in the use of the institute (...)”. See Masson and Marçal (n 133) 219.

291 Fonseca (n 98) 125.

292 In this respect, see different ruling from the Superior Court of Justice: STJ, HC 392452 AgInt [2017]; STJ, RHC 69988 [2016]; STJ, RHC 68542 [2016]; STJ, APn $843 \mathrm{AgRg}$ [2016].

293 STF, HC 127483 [2015]. This ruling is often mentioned as an important in Brazilian case law. See e.g. STF, PET 5885 AgR [2016]; STF INQ 4405 AgR [2018]; and STJ, RHC 43776 [2017].

294 STF, HC 127483 [2015]. 
these reasons, "the collaboration agreement cannot be challenged by the cooperator's accomplices in the criminal organization and in the committed offenses, even if they are explicitly named in the cooperation report". ${ }^{295}$ According to the decision, a collaboration agreement is essentially a bilateral transaction that does not itself interfere in the rights of other defendants, who may defend themselves by "crosschecking, in court, the report on relevant facts made by the cooperator and the evidence brought by him". 296

This decision of the Federal Supreme Court addressed collaboration agreements within the traditional framework of private contract law and applied explicitly the res inter alios acta principle, according to which a third party cannot interfere in agreements they have not concluded. ${ }^{297}$

The ruling provided the basis for several judicial decisions that repeatedly denied accused the right to question before a court the legality of a collaboration agreement concluded by a cooperating defendant. In this regard, the Brazilian Superior Court of Justice decided that a collaboration agreement "generates rights and obligations only for the signing parties, in no way interfering in the legal sphere of third parties, even if they are referred to in the cooperator's report". ${ }^{298}$ Another decision affirmed that a collaboration agreement "does not by itself affect the rights of third parties, who lack a legal interest to question the legality of the arrangement". ${ }^{299}$ A third ruling decided that "in a collaboration agreement, there

295 ibid.

296 ibid.

297 The res inter alios acta principle is long-standing in private contract law, both in common law and civil law countries. On this concept Herbert F. Goodrich notes: "No one disputes the soundness of the general proposition that to recover for the consequences of a negligent act the plaintiff must be one to whom the actor owed a duty to be careful. (...) Subject to exceptions not important here, $\mathrm{C}$, a stranger to the contract, gains no rights from it. That transaction is as to him res inter alios acta". See Herbert F Goodrich, 'Privity of Contract and Tort Liability' (1922) 21 Michigan Law Review 200, 200. Similarly, Weir asserts that "third persons under the common law system cannot claim rights, in the ordinary case, under contracts to which they were not parties and with respect to which they gave no consideration". See JA Weir, 'Contract - Rights of Third Persons under Contracts to Which They Are Not Parties' (1943) 5 Alberta Law Quarterly 77. For an analysis of the principle in Brazilian private law, see Otavio Luiz Rodrigues Junior, 'A doutrina do terceiro cúmplice: autonomia da vontade, o princípio res inter alios acta, função social do contrato e a interferência alheia na execução dos negócios jurídicos' (2004) 821 Revista dos Tribunais 80.

298 STJ, RHC 68542 [2016].

299 STJ, RHC 69988 [2016]. 
is no provision that affects the interests of third parties" and, therefore, an accused has no right to contest an agreement concluded by a cooperator and public prosecutors. ${ }^{300}$

According to this position, only the contracting parties - the Public Prosecution Office and the cooperator - can discuss judicially the arrangements they have negotiated. Other defendants, whose acts have been reported by the cooperator, have the right to refute at trial the allegations and cross-examine the evidence, but may not submit judicial appeals to question the regularity of the collaboration agreement. The application of the res inter alios acta principle protects collaboration agreements from legal challenges filed by defendants accused by the cooperator of criminal behavior, preventing more intense judicial scrutiny of the practice of the rewarded collaboration regulation and fostering a negotiation-friendly environment.

\section{Conclusion: a contractualist approach to collaboration agreements}

Until recently, negotiations between defendants and law enforcement authorities played a minor role in Brazilian criminal justice. In 1995, the Small Claims Act introduced possibilities for the resolution of criminal proceedings through negotiated solutions, but limited the employment of these mechanisms to cases related to minor offenses. Besides these possibilities, Brazilian law did not establish other legitimate space for negotiation between procedural participants, and the traditional model of official investigation remained the normal reality. The introduction of leniency policies by the Competition Act and especially by the Organized Crime Act changed this scenario. Over recent years, the negotiation of antitrust leniency agreements and collaboration agreements has become a common feature of the Brazilian justice system, particularly in the prosecution of corporate wrongdoing and acts of corruption.

According to the text of both statutes, the terms of exchange in these negotiations are quite simple: defendants assist enforcement authorities in the investigation of other agents and receive in return a reduction - partial or full - of penalties. The practice of collaboration agreements, however, has evolved in a highly distinctive manner. Through collaboration agreements, cooperating defendants and public prosecutors have designed original clauses, set up sophisticated solutions and expanded the negotiation fo-

300 STF, INQ 4619 AgR [2018]. 
rum well beyond its statutory limits. As an extensive body of cases indicates, legal practitioners drew on the communication forum engendered by the Organized Crime Act to develop a flexible and comprehensive system of arrangements and devise striking innovations.

This unexpected development received strong support from public authorities. The Federal Public Prosecution Office defended this system of negotiation on multiple occasions and enacted, in 2018, an orientation note that endorsed the innovations forged through the practice of collaboration agreements. The Brazilian judiciary, led by the Federal Supreme Court, repeatedly validated ingenious agreements and, in crucial disputes, affirmed the legality of the inventive employment of the rewarded collaboration regulation.

This solid judicial support was often based on the notion that collaboration agreements are part of a distinct system of criminal justice, one with a different rationale and different foundations from the traditional Brazilian criminal procedure. In this emerging paradigm of "consensual criminal justice", procedural participants would enjoy wide freedom to negotiate over the matters examined in investigations and dispose of criminal cases. According to this view, that could be called a "contractualist approach" to collaboration agreements, concepts and principles usually related to private law become central elements in the application of the rewarded collaboration rules.

Within this context, principles such as individual autonomy, good faith, legal certainty and protection of legitimate expectation are repeatedly used to devise answers to the many questions that arise from legal practice. Traditional doctrines of contract law - such as the rules of "res inter alios acta", of "venire contra factum proprium", and of "pacta sunt servanda" - become frequent interpretative tools in disputes regarding collaboration agreements. Courts ratify important decisions regarding the limits of collaboration agreements with express reference to civil law and to the Code of Civil Procedure. The assimilation of the experience of other countries with consensual mechanisms in criminal procedure, particularly the U.S. system of plea bargaining, is also frequently invoked to validate the novelties brought about by negotiations of collaboration agreements. 


\section{Chapter II - Collaboration agreements and macro- delinquency in Brazilian recent experience: notable results in the prosecution of corruption networks}

\section{Introduction}

The introduction of the rewarded collaboration regulation was part of a wide set of measures designed by the 2013 Organized Crime Act to strengthen the prosecution and punishment of activities committed by criminal organizations. According to the 2013 Organized Crime Act, a criminal organization is an association of four or more individuals, with an organized structure characterized by the division of tasks, and aimed at the acquisition of gain through the commitment of crimes. ${ }^{301}$ The 2013 Organized Crime Act authorizes the negotiation of collaboration agreements in the investigation of a wide array of crimes: it stipulates that the maximum imprisonment penalty for these crimes must be higher than four years ${ }^{302}$, but this threshold is not difficult to reach in Brazilian criminal law.

Despite the broad applicability of the rewarded collaboration regulation, the Brazilian practice of collaboration agreements thrived in the investigation of corporate and government crimes and, unlike the experience of other countries, was not developed for the prosecution of violent crimes. In Germany, political terrorism and drug traffic have been the main concerns that led to the introduction of the crown-witness regulation. ${ }^{303}$ In Italy, cooperation with offenders has been used prominently in investigations of mafia groups. ${ }^{304}$ In the United States, where the use of cooperating defendants is an antique and entrenched practice in the justice system, law enforcement authorities draw on the assistance of accused in investigations

301 Brazilian Organized Crime Act 2013, art $1^{\circ} \mathbb{S} 1^{\circ}$.

302 idem.

303 See item IV.3.a. Also: Breucker and Engberding (n 11) 11-16; Hassemer, 'Kronzeugenregelung Bei Terroristischen Straftaten Thesen Zu Art. 3 Des Entwurfs Eines Gesetzes Zur Bekämpfung Des Terrorismus' (n 11).

304 Mehrens (n 11) 173-179. 
of a wide array of wrongdoings, including violent crimes committed by street gangs and terrorist organizations. ${ }^{305}$

Unlike these experiences, the Brazilian practice of collaboration agreements was developed essentially for the prosecution of government corruption and corporate wrongdoing, often involving prominent executives and senior politicians. Since the enactment of the Organized Crime Act, the main scenario in which the practice of collaboration agreements has been developed is the group of large-scale investigations dubbed "Operation Car Wash", which over recent years has inquired into corruption schemes, business cartels and money laundering practices. Since the conclusion, in 2014, of the first collaboration agreement in "Operation Car Wash", law enforcement authorities have repeatedly relied on the assistance of cooperating defendants to investigate corporate wrongdoing and corrupt practices.

This chapter analyzes the central characteristics of these crimes and their importance in the development of the Brazilian practice of collaboration agreements. Section II.2 gives an overview of "Operation Car Wash" and describes its comprehensive scope, long duration and far-reaching impacts on Brazilian political and economic life. Section II.3 analyzes the types of wrongdoings investigated in the context of "Operation Car Wash", particularly under the concept of "corruption networks", and underlines some of their essential features: item II.3.a examines the legal interests affected by these conducts; item II.3.b assesses the organizations involved in these practices; and item II.3.c addresses their social impact. Section II.4 analyzes the strong public support for the Brazilian practice of collaboration agreements and their connection to the prosecution of macro-delinquency and to the ideal of consensual justice.

\section{Operation Car Wash}

Since the enactment of the 1988 Federal Constitution, corruption has been a perennial subject in Brazilian public debate and political life. ${ }^{306}$ The new Constitution empowered law enforcement authorities and boosted expectations regarding control of the long-standing problems with corruption of

305 Acconcia and others (n 29) 1119. For a thorough description of the U.S. experience, see Jeßberger, Kooperation Und Strafzumessung: Der Kronzeuge Im Deutschen Und Amerikanischen Strafrecht (n 1) 208-248.

306 Prado and Carson (n 13) 742-768. 
political representatives and public officials. ${ }^{307}$ Since 1988, every elected president has confronted serious investigations of corruption at different levels of the Administration ${ }^{308}$ and corruption scandals have played a major role in Brazilian democratic life. ${ }^{309}$ In recent decades, investigations of corruption schemes have increased, often through joint efforts by different enforcement agencies, drawing intense media coverage. ${ }^{310}$ The development of these investigations and a permanent perception of impunity - associated with the problems of Brazilian criminal justice system, often portrayed as slow moving, ineffective, ${ }^{311}$ and complacent with regard to the wrongdoings of the political and economic elites ${ }^{312}$ - led to growing impatience with corruption in Brazilian public opinion. ${ }^{313}$

In this context, the investigations dubbed "Operation Car Wash", which since 2014 have inquired into different criminal practices in large public contracts carried out by Petrobras, the Brazilian state-owned oil and gas company, represent a key milestone. Started in 2014 as a small inquiry of a local money-laundering scheme, "Operation Car Wash" rapidly evolved in-

307 For an historic overview regarding political corruption in the process of re-democratization in the first years of the 1988 Constitution, see David Fleischer, 'Political Corruption in Brazil: The Delicate Connection with Campaign Finance' (1996) 25 Crime, Law and Social Change 297.

308 As stated by Timothy J. Power and Matthew M. Taylor, "each of the five postauthoritarian presidential administrations has been sullied by accusations of corruption".

309 For an analysis of the important role played by the concept of corruption in Brazilian society, see Ana Frazão and Ângelo Carvalho, 'Corrupção, Cultura e Compliance: O Papel Das Normas Jurídicas Na Construção de Uma Cultura de Respeito Ao Ordenamento' in Ricardo Villas Bôas Cueva and Ana Frazão (eds), Compliance: perspectivas e desafios dos programas de conformidade (Fórum 2018) 133-136.

310 As noted by Mariana Mota Prado and Lindsey Carson, these investigations are usually called "operations" and "are very visible, often being described by catchy nicknames that facilitate publicity. They are accompanied by wide press coverage". See Prado and Carson (n 13) 758.

311 Katherine Bersch, Sérgio Praça and Matthew Thaylor, for instance, note "[...] the problems of Brazil's judiciary, which is exceedingly slow and overburdened, leading to few convictions for corruption”. See Katherine Bersch, Sérgio Praça and Matthew M Taylor, 'State Capacity, Bureaucratic Politicization, and Corruption in the Brazilian State' (2017) 30 Governance 105, 112.

312 For such a critical portrait of the Brazilian Judiciary, see Augusto Zimmermann, 'How Brazilian Judges Undermine the Rule of Law : A Critical Appraisal' (2008) 11 International Trade and Business Law Review 179.

313 Frances Hagopian, 'Delegative Democracy Revisited Brazil's Accountability Paradox' (2016) 27 Journal of Democracy 119, 120. 
to a "monster investigation" ("Monster-Verfahren"), ${ }^{314}$ being nowadays recognized as the largest corruption investigation ever conducted in Brazil and probably one of the largest ever conducted in Latin America. ${ }^{315}$

According to the complaints filed by the Federal Public Prosecution Office, the case deals with "a huge criminal scheme, involving the practice of economic crimes, corruption, and money laundering, with the formation of a large and powerful cartel". ${ }^{316}$ Pursuant to the criminal charges, shareholders and executives of the main Brazilian construction companies formed a "club" that divided the market and rigged the bids on Petrobras contracts, illegally overcharging the company. ${ }^{317}$ In accordance with the complaints, while the corrupt conduct of Petrobras employees provided stability for the cartel's market division and ensured favorable treatment for its members, illegal payments were also made to senior political figures, responsible for endorsing and maintaining Petrobras directors in their positions.

Because of the large ensemble of individuals and companies investigated, the financial sums involved and the rapid results achieved, "Operation Car Wash" has profoundly affected Brazilian society. The media coverage generated by the investigations produced an "informational tsunami" about corruption schemes in the public sector ${ }^{318}$ with little parallel in other contemporary democracies. Dozens of politicians from various parties and different ideological orientations were formally prosecuted for alleged involvement in the practices, generating extremely harmful repercussions for the political elite of the country. ${ }^{319}$ The development of the "Operation

314 The concept of "monster investigation" or "monster proceeding" ("Monster-Verfahren") is well known in German criminal law. According to Bernd Schünemann, the concept relates to complex and broad investigations, which can last for months or even years, often in the field of economic criminality. See Schünemann, 'Zur Kritik Des Amerikanischen Strafprozessmodells' (n 25) 570-571. Analyzing a 2012 judgment of the Brazilian Federal Supreme Court related to another corruption scandal, Luís Greco and Alaor Leite employed the term "monster decision" ("Monsterentscheidung"). See Greco and Leite (n 17).

315 Kurtenbach and Nolte (n 16) 5.

316 According to the charges presented by the Federal Public Prosecution Office in the following proceeding: JFPR, AP 5013405-59.2016.404.7000 [2016].

317 See the charges presented by the Federal Public Prosecution Office in the following proceeding: JFPR, 5046512-94.2016.4.04.7000/PR [2016].

318 Melo (n 14) 60.

319 In this regard: "As the Operation Car Wash investigations deepened, the political sphere was near panic". See Felipe Nunes and Carlos Ranulfo Melo, 'Impeachment, Political Crisis and Democracy in Brazil' (2017) 37 Revista de Ciência política (Santiago) 281, 282. 
Car Wash" played a major role in the 2016 impeachment process of the Brazilian President, ${ }^{320}$ and led to the filing of two criminal cases against her successor in 2017.321 The investigations led to the arrest of executives of leading Brazilian infrastructure conglomerates and of the chairman of the largest investment bank in Latin America. ${ }^{322}$

Data from 2018 shows that more than 150 individuals have already been convicted in proceedings related to "Operation Car Wash". ${ }^{323}$ This group contains several individuals from the country's economic and political elite, including a former President of the Republic, a former President of the House of Representatives, members of Congress and former Ministers, as well as partners and directors of some of Brazil's largest corporate groups.

"Operation Car Wash" also seriously affected the companies involved in the investigated conduct, which were subject to grave financial fines and other penalties, such as the termination and suspension of contracts with the public sector. The financial situation of some of the main Brazilian conglomerates was so badly shaken by the investigations that the Central Bank of Brazil stated that this situation could bring risks to the national financial system. ${ }^{324}$ Given that several of the investigated corporations have global presence and that some of the scrutinized conduct took place out-

320 President Dilma Roussef's impeachment, in 2016, occurred on the grounds that she had disrespected budget rules, and not because she had committed any act investigated under the Car Wash Operation. However, the development of the criminal investigations, since 2014, was essential to create a political climate favorable to the development of the impeachment procedure. In this regard, Nunes and Melo warn of the need "to distinguish between the casual elements without which the context of the crisis would have not been configured, and the mechanism that were effectively capable of leading to the interruption of the tenure in question". See Nunes and Melo (n 320) 283. Along the same lines, Brian Winter recognizes that, although "the technical grounds for her impeachment were that she manipulated the federal budget to conceal the scale of the country's mounting deficits", "the impeachment was driven by public anger at a president who had overseen the country's worst recession in more than a century and by the exposure of a multibillion-dollar corruption scandal". See Brian Winter, 'Brazil's Never-Ending Corruption Crisis Why Radical Transparency Is the Only Fix' 96 Foreign Affairs (2017) 87.

321 Mello and Spektor (n 9) 114.

322 Melo (n 14) 60.

323 Moro (n 31) 157.

324 Oliveira, Gesner and Rodas, Joao and Guimaraes, Denis and Marcato, Fernando Scharlack and Curi, Andrea and Pastore, Ricardo and Farina, Tatiana, 'Working Paper on Brazilian Cartel Investigations, the 'Operation Car Wash' 
side of Brazil, "Operation Car Wash" ended up causing legal consequences in different countries, gaining international attention. ${ }^{325}$ In an agreement jointly signed with Brazilian, American and Swiss authorities, one of the investigated corporate groups agreed to pay US\$ 3.5 billion as a penalty for conduct related to the corruption of public officials in Brazil and abroad". ${ }^{326}$ In 2018, Petrobras entered into a 2.95 billion dollar agreement to compensate foreign investors in the United States, who alleged they had been harmed by acts of corruption in the company. ${ }^{327}$ In Peru, investigations led to the pre-trial detention of a former President and former First Lady. ${ }^{328}$ In Ecuador, a former Vice-President was sentenced to six years' imprisonment for involvement in illicit activities carried out with Brazilian companies. ${ }^{329}$ Investigations also reached one of the leading shipbuilding companies in Singapore, which agreed to pay a penalty of US\$ 422

(Operação Lava Jato) and Its Impacts on the Economy' (CEDES - Center of Studies on Economic and Social Law 2015) <https://ssrn.com/abstract=2710438> accessed 1 May 2019, 98-99.

325 With regards to the subject, Tourinho states that: "Like many major corruption schemes, Brazil's was in many ways fundamentally transnational. The uncovered facts so far directly involve 14 countries, wi th implications for former or current heads of states of Argentina, Chile, Colombia, the Dominican Republic, Ecuador, Guatemala, Mexico, Panama, Peru, and Venezuela (BBC-Brasil 2017). Odebrecht alone paid almost US\$ 800 million in bribes abroad. As a result, investigations have thus far involved 44 jurisdictions (Giacomet Junior and Silveira 2017) and agreements are simultaneously being negotiated (or have been reached) in several states, most notably the United States and Switzerland". See Tourinho (n 15) 1-2.

326 For more information regarding this case, see: Department of Justice, 'Odebrecht and Braskem Plead Guilty and Agree to Pay at Least \$3.5 Billion in Global Penalties to Resolve Largest Foreign Bribery Case in History' (Department of Justice, 21 December 2016) <https://www.justice.gov/opa/pr/odebrecht-and-brask em-plead-guilty-and-agree-pay-least-35-billion-global-penalties-resolve $>$ accessed 1 October 2019.

327 For more information regarding this subject, see: Sabrina Valle, 'Petrobras to Pay $\$ 3$ Billion to End U.S. Lawsuits over Graft' Bloomberg: Markets (3 January 2018) <https://www.bloomberg.com/news/articles/2018-01-03/petrobras-to-pay-3 -billion-to-end-u-s-class-action-over-graft $>$ accessed 2 October 2019.

328 For more information regarding this case, see: 'Peru Ex-President Ollanta Humala and Wife Put in Pre-Trial Detention' BBC News (14 July 2017) $<$ https://ww w.bbc.com/news/world-latin-america-40605823> accessed 2 October 2019.

329 For more information concerning this case, see: 'Odebrecht Scandal: Ecuador Vice-President given Six Years' Jail' The Guardian (14 December 2017) <https:// www.theguardian.com/world/2017/dec/14/odebrecht-scandal-ecuador-vice-presi dent-given-six-years-jail> accessed 2 October 2019. 
million after admitting to making illegal payments to Brazilian government officials. 330

A defining feature of "Operation Car Wash" was the large-scale use of the rewarded collaboration regulation, introduced in 2013 by the Organized Crime Act. ${ }^{331}$ From August 2014, when a former Petrobras director signed the first collaboration agreement with the Public Prosecution Office, up to the end of 2017, nearly 300 agreements with cooperators were signed within the scope of "Operation Car Wash". ${ }^{332}$ The investigations also relied on the antitrust leniency program, provided for in the Competition Act. In March 2015, the first antitrust leniency agreement related to "Operation Car Wash" was signed and, since then, nine other agreements have been concluded during the investigation of multiple cartels in public tenders. ${ }^{333}$ The group of individuals and companies that have concluded collaboration agreements and antitrust leniency agreements contains highranking politicians, world-renowned executives and some of the biggest Brazilian corporate groups.

\section{Corruption networks}

Since the introduction of the antitrust leniency program by the Competition Act, and of the rewarded collaboration regulation by the Organized Crime Act, the use of leniency policies in Brazil has occurred mainly in investigations of cartels between companies and offenses related to corrup-

330 For more information on this subject, see: Nate Raymond, 'Keppel Unit to Pay \$422 Million to Resolve Petrobras Bribery Probes' Reuters (23 December 2017) $<$ https://www.reuters.com/article/us-keppel-corp-settlement/keppel-unit-to-pay-4 22-million-to-resolve-petrobras-bribery-probes-idUSKBN1EH035> accessed 2 October 2019.

331 Monica Arruda de Almeida and Bruce Zagaris, 'Political Capture in the Petrobras Corruption Scandal: The Sad Tale of an Oil Giant' (2015) 39 The Fletcher Forum of World Affairs 87, 89. Highlighting the changes brought by these developments to the position of Brazilian lawyers, see Frazao and Athayde (n 6) 309-314.

332 According to data submitted by the Federal Prosecution Office in December 2017. See Modzeleski (n 113).

333 According to the data disclosed by CADE (Administrative Council for Economic Defense). See CADE, 'Cade Celebra Acordo de Leniência Em Investigação de Cartel Em Licitações No Distrito Federal' Notícias (12 July 2017) <http://ww w.cade.gov.br/noticias/cade-celebra-acordo-de-leniencia-em-investigacao-de-carte l-em-licitacoes-no-distrito-federal> accessed 26 September 2019. 
tion of public officials. ${ }^{334}$ In many of these investigations, these two types of wrongdoings - business cartels and public sector corruption - have been intrinsically connected, requiring the joint action of law enforcement authorities from different branches. ${ }^{335}$ In the context of "Operation Car Wash", the scenario described by enforcement authorities involves an interconnection between cartels, corruption schemes and money laundering. ${ }^{336}$ According to the criminal charges, cartels generated greater profits for corporations in contracts with state-owned companies, while the corruption of political agents and public employees facilitated the collusion and financial transactions laundered the proceeds of wrongdoings. 337

334 As noted by Cavali (n 36) 256.

335 Concerning the joint action between authorities in those cases, see Ribeiro, Cordeiro and Guimarães (n 5) 196-197.

336 A report of the Federal Prosecution Office affirms that Operation Car Wash is "the most relevant investigation to uncover the largest corruption scheme entrenched in the political and economic system". See Ministério Público Federal, 'Relatório de Resultados' (n 136) 17. According to the report: "The dynamics of the scheme, that had existed for more than a decade, functioned based on bribe payments to high executives of the state company and to other public agents. The illicit amounts were paid by big contractors that organized themselves in a cartel to sign contracts with Petrobras through fraudulent bids. The contractors were cartelized in a "club" to settle the winners of bids. (...) To ensure the cartelization, public agents of the state company were coopted. Employees not only omitted themselves in face of the cartel, of which they had knowledge, but also favored it, restricting the number of companies invited to bids and including the winner between the cartel participants, as in a fixed game. Investigations demonstrated that, between the beneficiaries, there were political agents. (...) Those political agents used their influence to appoint people they trusted to Petrobras' boards, according to the political parties to which they belonged, to, based on the signed contracts, receive illicit amounts" (17).

337 The connection between business cartels and corruption practices is often cited in the criminal charges presented by the Federal Public Prosecution Office in the cases related to Operation Car Wash: "in the course of Operation Car Wash, the investigation discovered a gigantic criminal scheme, of which Petrobras was a part, that operated since, at least, 2004, involving the practice of economic crimes, corruption, bid rigging and money laundering, with the formation of a large and powerful cartel (...) Besides that, (...) the investigation revealed the existence of a complex and sophisticated criminal organization, structured to enable a scheme of political corruption and allocation of public offices to raise bribes that financed political parties and increased the assets of the politicians involved. For that scheme to work, high-ranking officials from Petrobras and from other government bodies and public companies were co-opted. Therefore, the companies that concluded agreements with Petrobras ("economic branch"), due to a systemic corruption scheme, paid undue advantages to Petrobras' direc- 
This dynamic, rather than being a uniquely Brazilian arrangement, reflects a pattern that has been observed in other countries, as has been reported in the literature. In this regard, Donatella della Porta and Alberto Vannucci describe so-called "complex networks of corruption", in which

various actors intervene, supplying the resources necessary not only to the successful conclusion of the hidden exchange but also to guarantee its implementation, protection from risks of external intrusion, reinvestment of illicit capital, and the maintenance of a resilient conspiracy of silence. ${ }^{338}$

In these systems of corruption, cartels formed by legitimate corporations carve up the public bidding market, bribing public officials and political agents in order to ensure higher public procurement prices, to guarantee compliance with cartel decisions and to exclude companies that are not part of the collusion. ${ }^{339}$

Likewise, Britta Bannenberg, analysing the German experience, describes the so-called "corruption networks" ("Korruptions-Netzwerke"), in which "various persons on both sides (payers and receivers) are involved for years, sometimes decades," and where "corruption is strategic, is employed in a massive manner by corporations and is connected to other crimes". ${ }^{340}$ According to the author, in these structures "corruption is developed as a system, to define important decisions for the benefit of a group or a cartel, generally favoring a company, to eliminate or discourage competition". ${ }^{341}$

The concept of corruption networks closely matches the arrangements described by Brazilian law enforcement authorities in the context of "Operation Car Wash", with large contractors, prominent businessmen and senior politicians colluding over decades to obtain illicit gains in public con-

tors ("administrative branch") and to political officials ("political branch") that varied from $1 \%$ to $3 \%$ of the contract value." See the criminal charges presented by the Federal Public Prosecution Office in the following proceeding: JFPR, AP 5063271-36.2016.4.04.7000 [2016].

338 Alberto Vannucci and Donatella Della Porta, The Hidden Order of Corruption: An Institutional Approach (Ashgate Publishing Limited 2013) 30.

339 ibid 31.

340 Bannenberg (n 17) 108. Also using the term "corruption networks" ("Korruptions-Netzwerke"), see Simone Nagel, Entwicklung Und Effektivität Internationaler Maßnabmen Zur Korruptionsbekämpfung (Nomos 2007) 34.

341 Bannenberg (n 17) 108. Also noting that business cartels and corrupt practices are often connected, see Dölling (n 12) 348. 
tracts. ${ }^{342}$ The individuals responsible for these conducts hold central positions in legitimate organizations, such as multinational corporations and political parties, disposing of a wide array of resources to implement sophisticated strategies. ${ }^{343}$

Thus, the Brazilian practice of leniency policies has arisen largely from the prosecution of a specific form of criminality, carried out with the support, and in the interest of, business conglomerates and within sectors of the state, involving a large group of individuals - many of them highranked - in legitimate organizations. ${ }^{344}$ This scenario is clearly different from the experience of other countries with the use of cooperating defendants as investigative mechanisms, which have occurred mainly in the context of illicit markets and violent crime, especially in the fields of drug trafficking and terrorism. ${ }^{345}$

The specific characteristics of corruption networks and business cartels create an environment that is conducive for law enforcement authorities to seek the cooperation of private agents for the prosecution and prevention

342 According to the Federal Public Prosecution Office, the investigations revealed "the systemic corruption entrenched in the Brazilian political and economic system that spread among other countries", marked by the formation of strong cartels with the capture of public employees and political representatives. See Ministério Público Federal, 'Relatório de Resultados' (n 136) 13 and 17-18.

343 Bannenberg (n 17) 109-111. Also Vannucci and Della Porta (n 339) 31-33.

344 This can be seen from the examination of the main rulings of Brazilian higher courts regarding the use of collaboration agreements, all of them concerning controversies arising of investigations into suspected white-collar offences. See e.g. STF, HC 127483 [2015]; STF, PET 7074 [2017]; STF, PET 5885 AgR [2016]; STJ, RHC 43776 [2017] and STJ, HC 221231 [2017].

345 In Germany, the modern development of these mechanisms is directly related to the occurrence of acts considered to be political terrorism. See: Breucker and Engberding (n 11) 11-16. The investigation of drug trafficking has also been a major concern for this development. See: Jaeger (n 3). In the Italian experience, the prosecution of mafia organizations constituted the central factor of the use of cooperating defendants. See: Mehrens (n 11) 173-179; Enzo Musco, 'Los Colaboradores de La Justicia Entre El Pentitismo y La Calumnia: Problemas y Perspectivas' (1998) 2 Revista Penal 35, 36-38. For a general overview, see: Tak (n 4). 
of criminal behavior, ${ }^{346}$ either through leniency policies ${ }^{347}$ or other legal mechanisms. ${ }^{348}$ The following items analyze some of these characteristics, which - while favoring the use of leniency policies - also bring specific risks and concerns. ${ }^{349}$

\section{a. Collective goods, diffuse losses}

A shared characteristic of corruption networks and cartels is the presence of serious obstacles faced by law enforcement authorities in the prosecution of the individuals responsible for the commitment of the offenses. ${ }^{350}$ The prosecution of these types of crimes faces structural limitations, 351 which make the cost of investigating suspicious conduct particularly high

346 For a critical view on this type of "Public Private Partnership" in the prosecution of corporate crimes, see: Hefendehl, 'Außerstrafrechtliche Und Strafrechtliche Instrumentarien Zur Eindämmung Der Wirtschaftskriminalität' (n 12), 846-847. For a good description of this trend in the prosecution of corruption, see: Centonze (n 1$)$.

347 For an emphatic defense of the use of leniency policies in the prosecution of economic crimes, see: Buzari (n 12) 112-114. For another favorable argument, see: Jeßberger (n 1) 305. Similarly, with regards to corruption investigation and prosecution, see: Lejeune (n 12) 87.

348 Besides leniency policies, another main mechanism of cooperation between public authorities and private agents are the so-called "internal investigations", through which corporations conduce, autonomously and with their own resources, inquiries for clarifying suspicious conducts committed by their employees. For a good overview of the theme, see: Martín (n 23) 69-92. The author draws attention to the "aggressiveness" of the model developped in the United States for this type of cooperation. For a critical approach to that kind of cooperation, see Greco and Caracas (n 23) 1-16, stating that the combination between the private and public elements in the internal investigations brings serious risks to the liberal model of the criminal procedure.

349 For a more thorough analysis of the expectations and risks associated with the employment of leniency policies in the prosecution of corporate crimes and corruption, see Chapter III.

350 The literature on the matter is extensive. Greco and Leite describe the evidentiary difficulties as a "constant problem in the field of the prosecution of corporate and government criminality ("Regierungskriminalität")". See Greco and Leite (n 17) 290. Similarly, Simone Nagel points out that the discovery of corrupt conducts by the investigating authorities encounters multiple difficulties. See Nagel (n 341) 33. In this respect, see also: Bannenberg (n 17) 64-65.

351 Michael Lindemann mentions "structural specificities" that create "substantial difficulties" in the prosecution of corruption and of economic crimes: Lindemann (n 17) 127-130. Regarding the challenges regarding the collection of evi- 
and create particular challenges for the effective enforcement of criminal law. 352

One difficulty arises from the type of interests affected by corruption networks and cartels. Although these conducts may cause losses for specific agents or corporations, their negative effects go far beyond any individual legal sphere, affecting an undetermined and unlimited group of subjects. ${ }^{353}$ The direct economic impacts caused by cartels and corruption networks are identical: an increase in prices and a reduction in quality of services and products. ${ }^{354}$ But the economic repercussions are not the only damage caused by these offenses: cartels and corruption impair the proper functioning of the competition process in a market economy and the public confidence in the state, causing a series of pervasive harmful effects that spread throughout society, such as the erosion of democratic values ${ }^{355}$ and the reduction of economic opportunities. ${ }^{356}$ In both cases, the safeguarded interests are non-rivals and non-excludable in their consumption and cannot be divided and distributed among individuals. 357

Cartels and corruption networks cause losses that are felt diffusely by society, diluted over time and, therefore, are very difficult to associate direct-

dence in the investigation of antitrust offenses, see Ana Frazão, Direito Da Concorrência: Pressupostos e Perspectivas (Saraiva 2017) 294-297.

352 Martín (n 23).

353 In this regard, Roland Hefendehl states that conducts that restrict competition and corrupt conducts. perpetrated by public agents harm the so-called "collective legal goods" ("Kollektive Recthsgüter"). See Roland Hefendehl, Kollektive Rechtsgüter Im Strafrecht (Carl Heymanns Verlag KG 2002), 277-280 and 320-323.

354 Armando Zambrano Leal, Sociedad de Control y Profesión Docente. Las Imposturas de Un Discurso y La Exigencia de Una Nueva Realidad (Ashgate Publishing Limited 2012).

355 Bannenberg (n 17) 334.

356 In this regard: "Markets can be dominated by a few firms, charging exorbitant prices and blocking the entry of more efficient rivals and new technologies. Markets, left to their own devices, can cease to be inclusive, becoming increasingly dominated by the economically and politically powerful. Inclusive economic institutions require not just markets, but inclusive markets that create a level playing field and economic opportunities for the majority of the people. Widespread monopoly, backed by the political power of the elite, contradicts this". See Ron Smith, Why Nations Fail: The Origins of Power, Prosperity, and Poverty, vol 157 (Crown Business 2012) 323-324.

357 According to Roland Hefendehl, these features are condition for the characterization of collective legal goods. See Roland Hefendehl, 'Das Rechtsgut Als Materialer Angelpunkt Einer Strafnorm', Die Rechtsgutstheorie: Legitimationsbasis des Strafrechts oder dogmatisches Glasperlenspiel? (Nomos 2003) 126-127. 
ly with a specific conduct. ${ }^{358}$ The increase in the level of prices and the loss of quality caused by criminal conduct are not registered in commercial invoices or accounting documents and can only be measured by estimates almost always inaccurate - made by experts. ${ }^{359}$ While victims of traditional crimes against life or property are usually individuals immediately affected by the perpetrator's conduct, losses caused by corporate and government criminality tend to be indirect and abstract, ${ }^{360}$ leaving no tangible evidence of the damage caused. ${ }^{361}$

The lack of clear victims and direct losses causes major obstacles to the detection of wrongful behavior. ${ }^{362}$ The results produced by corporate crimes and corruption acts are complex and very difficult to identify and prove judicially. ${ }^{363}$ This characteristic hinders the effective enforcement of criminal law, generating particular worrisome dark figures of criminal behavior. ${ }^{364}$

\section{b. Legitimate and sophisticated organizations}

Another distinctive feature in the prosecution of cartels and corruption networks concerns the means employed for the commitment of the offenses. Unlike crimes such as robbery or murder, committed through the use of physical violence or the threat of its use, corporate wrongdoing and corruption strategies are implemented through social technologies, which enable individuals to make use of their positions in legitimate organizations

358 Lindemann (n 17) 127.

359 Patrick L Anderson, Theodore R Bolema and Ilhan K Geckil, 'Damages in Antitrust Cases' (2007) 2 Antitrust Damages - Anderson Economic Group.

360 For more information on the subject, see Klaus Tiedemann, 'Der Entwurf Eines Ersteu Gesetzes Zur Bekämpfung Der Wirtschaftskriminalität' (1975) 87 Zeitschrift für die gesamte Strafrechtswissenschaft 253, 271-272.

361 Maarten Schinkel notes that "anticompetitive acts often leave no obvious traces. There is not necessarily a body, signs of a break-in, or a crime scene". See Maarten Pieter Schinkel, 'Forensic Economics in Competition Law Enforcement' (2008) 4 Journal of Competition Law and Economics 1, 6.

362 Martín (n 23) 70.

363 Lindemann (n 17) 127.

364 Winfried Hassemer, 'Kennzeichen Und Krisen Des Modernen Strafrechts' (1992) 25 Zeitschrift für Rechtspolitik 378, 382; Buzari (n 12) 112-114. 
to obtain illegal gains. ${ }^{365}$ These practices are largely based on ordinary business practices and administrative actions, such as meetings between competitors, payments to other companies, bank transactions and exchanges of information, within the regular functioning of legitimate organizations. ${ }^{366}$ The acts constituting the illegal conduct are normally performed in environments where all the individuals are co-conspirators, eliminating any direct relationship between the offenders and the victims. ${ }^{367}$ Because these offenses occur through legitimate routines, their criminal nature is normally only perceptible by collecting and connecting several events, which are often separated by temporal, hierarchical and even geographical distances. ${ }^{368}$

Such offenses are commonly carried out within legitimate social organizations, such as corporations, political parties and business associations, benefiting from the complexity inherent to their daily routines. ${ }^{369}$ The structures and processes of these organizations create several opportunities for the development of wrongdoing, insofar as they provide the means to perform and to conceal illegal acts. ${ }^{370}$ Cartels, for instance, commonly make use of business associations for their activities, employing the legitimate structure of these institutions to provide greater cohesion and strength to the collusive agreement. ${ }^{371} \mathrm{~A}$ similar situation is also observed in corruption networks, which resort to legitimate expedients - such as po-

365 Susan P Shapiro, 'Collaring the Crime, Not the Criminal: Reconsidering the Concept of White-Collar Crime' (1990) 55 American Sociological Review 346,350 .

366 In this respect, see Jack Katz, 'Legality and Equality: Plea Bargaining in the Prosecution of White-Collar and Common Crimes' (1979) 13 Law \& Society Review 431, 436. The author describes crimes committed through acts that "appear to be part of ordinary occupational routines".

367 Wolfgang Lindner observes that corruption is committed through offender-offender relationships ("Täter-Täter-Beziehungen"). See Wolfgang Lindner, 'Korruptionsbekämpfung Im Anonymen Dialog. Ein Webbasiertes Hinweisgebersystem Im Einsatz Bei Der Zentralstelle Korruptionsbekämpfung Des LKA Niedersachsens' in Transparency International (ed), Korruption in Deutschland: Strafverfolgung der Korruption Möglichkeinten und Grenzen (allprintmedia 2004) 67. In this regard, also about economic crimes, see: Lindemann (n 17).

368 Shapiro (n 366) 354.

369 Stanton Wheeler and Mitchell Lewis Rothman, 'The Organization as Weapon in White-Collar Crime' (1982) 80 Michigan Law Review 1403.

370 Diane Vaughan, 'The Dark Side of Organizations: Mistake, Misconduct, and Disaster' (1999) 25 Annual Review of Sociology 271.

371 Scott D. Hammond highlights that the use of trade associations is a common tactic in international cartels: Scott D Hammond, 'Caught in the Act: Inside an 
litical donations and hiring of services from consultants - to make illegal payments to public agents. ${ }^{372}$ The development of criminal practices within legitimate organizations tends to be accompanied by active strategies of concealment and evidence destruction. ${ }^{373}$ As the main evidence of these crimes consists of internal documents - contracts, receipts of payments or transfers and electronic messages - there are various possibilities for manipulation or removal of these records through planned routines. ${ }^{374}$

A striking characteristic of corruption networks and cartels is their sophistication and capacity for developing complex strategies to implement illegal conduct. The creation of a long-term and stable system of illicit exchanges demands the development of a complex governance architecture and of "entrepreneurial management", 375 fostering a secure and predictable environment for the wide range of transactions that must occur for the success of the illegal enterprise. ${ }^{376}$ The organizations responsible for these offenses are constantly learning and evolving new ways to execute and conceal these strategies. ${ }^{377}$

Internacional Cartel' (Justice News, 2005) <https://www.justice.gov/atr/speech/ca ught-act-inside-international-cartel $>$ accessed 3 October 2019.

372 Vincenzo Dell'Osso, 'Empirical Features of International Bribery Practice: Evidence from Foreign Corrupt Practices Act Enforcement Actions' in Stefano Manacorda, Francesco Centonze and Gabrio Forti (eds), Preventing corporate corruption: the anti-bribery compliance model (Springer International Publishing 2014).

373 Shapiro (n 366) 354.

374 Ana María Neira Pena, 'Corporate Criminal Liability: Tool or Obstacle to Prosecution?' in Dominik Brodowski and others (eds), Regulating corporate criminal liability (Springer 2014) 199.

375 On this subject, see Vannucci and Della Porta (n 339) 34-37, 112-114.

376 Regarding corruption networks, Simone Nagel states that: "In addition, cases of corruption are often characterized by a particular complexity of the crime. For example, in order to cover up the criminally relevant factors, sham transactions are made, or wrong invoices are recorded. The main goal of this approach is to disguise the effective equivalent of benefits. The situation is further complicated by the fact that corruption cases do not take the form of singular exchanges but take place within elaborate corruption networks in which intermediaries or other persons of trust are used in arranging the unfair dealings. There are often enormous sums that are distributed through a complicated system of trust accounts and letterbox companies to numerous profiteers. The unmasking of corrupt machinations, which would lead to a legal application, is therefore often equated with a Sisyphean task". See Nagel (n 341), 34.

377 Wouter PJ Wils, 'Leniency in Antitrust Enforcement: Theory and Practice' (2007) 24 Conferences on New Political Economy 203; William E Kovacic, 'A 
The sophistication of these criminal strategies is also seen in the development of complex systems of task division, purposely designed to disperse illicit conduct over multiple acts practiced by several agents, at different times and in different places. ${ }^{378}$ This makes these behaviors appear legal and generates a distance between them, which hinders linking those acts to the practice of unlawful conduct and to the individuals actually responsible for the criminal offense. ${ }^{379}$ In hierarchical organizations, execution of illicit acts generally involves actions by subordinates, mere executors of superior orders, who may not even be aware of the illicit purpose accomplished through their acts. Division of tasks within the organization disrupts the flow of information about the offense not only to external investigators, but also to the organization's own members. ${ }^{380}$ The hierarchical structure and the organizational culture guarantee an atmosphere of strict obedience and create neutralizing effects that encourage the development of illegal activities. ${ }^{381}$ In this context, legitimate structures become instruments of protection for the final beneficiaries of sophisticated criminal schemes.

Another hindering factor in the effective prosecution of corruption networks and cartels arises from the problems of international judicial cooperation. ${ }^{382}$ Corruption networks and cartels often have a transnational dimension. ${ }^{383}$ Modern communication technology and wide mobility of people and goods facilitate the execution of criminal strategies across multiple countries, while legal issues regarding differences in justice systems hold back the efforts enforcement authorities. ${ }^{384} \mathrm{~A}$ main issue is the use of financial services offered by institutions located in tax havens, jurisdictions

Case for Capping the Dosage: Leniency and Competition Authority Governance' in Caron Beaton-Wells and Christopher Tran (eds), Anti-cartel enforcement in a contemporary age: leniency policies (Hart Publishing 2015).

378 Shapiro (n 366) 354.

379 Greco and Leite (n 17) 290.

380 Neira Pena (n 375) 199.

381 Hefendehl, 'Außerstrafrechtliche Und Strafrechtliche Instrumentarien Zur Eindämmung Der Wirtschaftskriminalität' (n 12) 819.

382 Gherardo Colombo, 'Investigating and Prosecuting Large-Scale Corruption: The Italian Experience' (2006) 4 Journal of International Criminal Justice 510, 519.

383 Nagel (n 341) 35-38.

384 According to Mark Pieth, "Under the conditions of deregulation, increased mobility and the potential of modern means of communication, corporate crime has also changed its image dramatically. The pressure to survive is a strong incentive and nationally diverging legal structures offer ample opportunity for 
with fiscal and corporate legislation characterized by low requirements in terms of information disclosure, creating a favorable environment for the concealment and laundering of criminal proceeds. ${ }^{385}$

\section{c. Major impacts on social life}

A main concern in the prosecution of corporate crimes and corruption acts relates to the grave impacts they produce. The use of legitimate organizations to implement illicit strategies expands the resources and the range of transactions at disposal of the wrongdoers, enabling the development of schemes that go well beyond traditional "face-to-face transactions". ${ }^{386}$ Legitimate organizations act on a much larger scale than isolated individuals and, when used for illegal purposes, enable the obtainment of massive illicit gains, consequently resulting in severe social losses. ${ }^{387}$

Recent decades have been marked by increasing concern regarding the losses caused by corporate crimes and corruption schemes. ${ }^{388}$ Multiple examples of corporate fraud have demonstrated how these offenses can abruptly wipe out the savings of thousands of individuals. ${ }^{389}$ Although the losses caused by corporate misbehavior have been neglected for a long

transnational illegal economic activities". See Mark Pieth, 'The Harmonization of Law Against Economic Crime' (2013) 1 European Journal of Law Reform $527,529$.

385 For a description of money laundering as an international problem, see: Lisa Barbot, 'Money Laundering: An International Challenge' (1995) 3 Tul. J. Int'l \& Comp. L.

386 Susan Shapiro, Thinking About White Collar Crime: Matters of Conceptualization and Research (National Institute of Justice 1980) 8

387 Wheeler and Rothman note that "the havoc caused when organizations are used outside the law far exceeds anything produced by unaffiliated actors". See Wheeler and Rothman (n 370) 1417-1418.

388 Several authors recognize this development. Regarding corruption, Dieter Dölling notes that "in the last decades, the consciousness regarding the dangers of corruption and the need for a vigorous control seems to have increased". See Dölling (n 12) 334. Greco observes that corruption is nowadays a matter of high relevance, both for legal policy and legal doctrine. See Luís Greco, 'Annäherungen an Eine Theorie Der Korruption' (2016) 163 Goltdammer's Archiv für Strafrecht 249, 249. Regarding corporate and economic crime, see Hefendehl, 'Außerstrafrechtliche Und Strafrechtliche Instrumentarien Zur Eindämmung Der Wirtschaftskriminalität' (n 12) 817-818.

389 Citing the examples of the Enron and Worldcom crisis: Roland Hefendehl, 'Enron, Worldcom Und Die Folgen: Das Wirtschaftsstrafrecht Zwischen Er- 
time, recent estimates suggest that this damage is of great relevance and affects multiple fields of the economy. ${ }^{390}$ Similarly, corrupt practices are recognized nowadays as highly harmful crimes. ${ }^{391}$ The damage is particularly relevant when it comes to sophisticated corruption networks, which may cause enormous social losses through the manipulation of public tenders and reinforcement of monopolistic positions. ${ }^{392}$

Besides causing severe monetary losses, corporate crimes and government corruption also entail important non-material consequences. Corruption erodes a central pillar of the concept of the liberal State: the division between public interest and private matters. ${ }^{393}$ The consequences of this erosion go well beyond the monetary damages, affecting in the long term multiple facets of a society, such as equality, productivity, economic investment and the quality of public services. ${ }^{394}$ Likewise, cartels and other collusive practices have far-reaching social effects, distorting competition and reducing incentives for innovation. ${ }^{395}$ Corporate fraud and economic crimes undermine public trust in the functioning of markets, without which contemporary capitalism cannot thrive. ${ }^{396}$ Particularly worrisome are practices of bid rigging, which put into question the integrity of governmental decisions. ${ }^{397}$

The major impacts caused by criminal conduct carried out through legitimate organizations have raised growing awareness of public authorities both in national and international arenas. The massive scale of economic

fordernissen Kriminalpolitischen Erwartungen Und Dogmatischen Erfordernissen' (2004) 59 JuristenZeitung 18, 19.

390 Lindner (n 368), 66-67.

391 Pieth (n 385) 535-539.

392 Bannenberg (n 17) 243-245.

393 Greco, 'Annäherungen an Eine Theorie Der Korruption' (n 389) 257.

394 For a detailed description of the consequences of corruption, see: Johann Graf Lambsdorff, 'Causes and Consequences of Corruption: What Do We Know from a Cross-Section of Countries?' in Susan Rose-Ackerman (ed), International Handbook on the Economics of Corruption (Edward Elgar 2006) 22-38.

395 Herbert Hovenkamp, The Antitrust Enterprise (Harvard University Press 2015) 13-14, 126.

396 Asserting the role of economic criminal law in preserving this public trust in market economies, see Hefendehl, Kollektive Rechtsgüter Im Strafrecht (n 354) 255-259.

397 Paulo Burnier and Victor Oliveira assert that a main consequence of bid rigging is "the diminishing of public confidence in the competitive process and in government. Those effects are even more harmful in developing economies like Brazil, where the strict control of public expenditure still remains a key factor for sustaining the domestic economy". See Burnier and Fernandes (n 7) 2. 
transactions now carried out by business corporations creates clear possibilities for the abuse of economic power, with enormous repercussions for the property and individual rights of a large group of individuals. ${ }^{398}$ Globalization and liberalization of markets has fostered the development of transnational organizations, whose activities may simultaneously affect various countries. ${ }^{399}$ All these factors have led to a global trend towards the enhancement in the enactment and prosecution of laws regarding corporate wrongdoing and corrupt practices. ${ }^{400}$

Another important issue in this context relates to the social standing of the main beneficiaries of these types of wrongdoings, who often hold positions of command and prestige in legitimate organizations. The traditional obstacles to holding these individuals accountable generate relevant questions regarding the notion of equal treatment within the criminal justice system. ${ }^{401}$ Increased awareness regarding corporate criminality has been accompanied by a widespread perception that criminal law does not reach the political and economic elites, who remain unaccountable despite their reckless behavior. ${ }^{402}$ The structure of modern corporations allows for an enormous concentration of power in the hands of few individuals, who profit greatly from the gigantic organizations following their instructions. ${ }^{403}$ When the activities of these organizations cause widespread losses, a public demand emerges for the punishment of the same individuals that profited the most in the buoyant times. ${ }^{404}$ The great damage caused by these practices and the social standing of the involved individuals demand,

398 For an analysis of the impact of economic crimes on individual freedom, see Naucke (n 18) 4-6, 80-85.

399 On the importance and difficulties of prosecuting transnational economic crime, see Pieth (n 385), 528-529.

400 Noting this trend in Germany: Schünemann, 'Vom Unterschichts- Zum Oberschichtsstrafrecht: Ein Paradigmawechsel Im Moralischen Anspruch?' (n 18) 16-18. Also: Marc Engelhart, 'Development and Status of Economic Criminal Law in Germany' (2014) 15 German Law Journal 693, 695-699.

401 For a thorough examination of this problem, see Schünemann, 'Vom Unterschichts- Zum Oberschichtsstrafrecht: Ein Paradigmawechsel Im Moralischen Anspruch?' (n 18).

402 Reporting on this perception in the United States in the aftermath of the 2008 financial crisis: Samuel W Buell, 'Is the White Collar Offender Privileged?' (2014) 63 Duke Law Journal 823, 826-827.

403 Naucke underlines the political consequences of this type of concentration of economic power: Naucke (n 18) 3-6.

404 Noting, in a critical tone, this trend, see Hefendehl, 'Enron, Worldcom Und Die Folgen: Das Wirtschaftsstrafrecht Zwischen Erfordernissen Kriminalpolitischen Erwartungen Und Dogmatischen Erfordernissen' (n 390) 22. 
for the preservation of the credibility of the justice system, a comprehensive investigation of this conduct and the imposition of penalties commensurate with the gravity of the offenses. ${ }^{405}$

4. Storming the castle: macro-delinquency, consensual justice and public support for leniency policies

Since its introduction by the 2013 Organized Crime Act, the practical development of the rewarded collaboration has occurred mainly in the prosecution of corporate crimes and corruption schemes, generating fast and visible results. A main sphere of development has been the investigations of "Operation Car Wash", in which hundreds of defendants opted to cooperate with enforcement authorities and assist in the prosecution against other accused.

Through collaboration agreements, cooperating defendants agreed to pay multi-million fines and compensate the Public Administration for the losses caused. ${ }^{406}$ Evidence provided by cooperators became central elements for justifying harsh investigative measures, such as dawn raids and pre-trial detentions. The agreements brought confessions from senior businessmen and public officials regarding an extensive list of crimes, as well as detailed accounts of conduct attributed to other individuals in crucial positions in the Brazilian political and economic system, such as former Presidents of the Republic and Chairmen of both Chambers of Congress. ${ }^{407}$ Cooperation reports also attributed unlawful conduct to hundreds of elect-

405 Hans Richter, 'Zur Wirtschaftskriminalität' in Dr Christian Müller-Gugenberger and Klaus Bieneck (eds), Wirtschafts-strafrecht: Handbuch des Wirtschaftsstrafund-ordnungswidrigkeitenrechts (Verlag Dr Otto Schmidt Koln 2011) 148.

406 According to the Federal Prosecution Office, until 2017, around 10,3 billion Brazilian Reais must be recovered through agreements concluded in the context of the Car Wash Operation in the Brazilian state of Paraná. See Ministério Público Federal, 'Relatório de Resultados' (n 136) 22.

407 For a description of the impact of Operation Car Wash in Brazilian political life, see Melo (n 14) 60. 
ed representatives, ${ }^{408}$ as well as shareholders and executives of transnational corporations. 409

The recent use of collaboration agreements in Brazil has been highly publicized and received strong media coverage. ${ }^{410}$ Based on the understanding that criminal prosecution should be as transparent as possible and that the evidence collected should be public, substantial parts of the material supplied by cooperators to law enforcement authorities were disclosed as the investigations progressed, even though judicial or administrative proceedings were in their early stages or, in some cases, no formal charges had yet been filed. ${ }^{411}$ Through collaboration agreements, different types of evidence - such as corporate documents and spreadsheets, tapped private reunions and countless hours of videotaped depositions - related to activities performed by the Brazilian business and political elites were widely publicized. ${ }^{412}$

These results created high hopes for the emergence of a solution for the long-standing problem of impunity and inequality within the Brazilian criminal justice system, generating strong popular support and interna-

408 Concerning the magnitude of the impact caused by the Car Wash Operation in Brazilian public life, it is worthwhile to mention the comparison made by the American journalist Anderson Cooper with the Watergate case: "Imagine if the Watergate investigation had led not only to the downfall of President Nixon, but also to allegations against his successor, plus the Speaker of the House, the leader of the Senate, a third of the cabinet, and more than 90 members of Congress". See Anderson Cooper, 'Brazil's "Operation Car Wash" Involves Billions in Bribes, Scores of Politicians' CBS News (2017) <https:/www.cbsnews.co $\mathrm{m} /$ news/brazil-operation-car-wash-involves-billions-in-bribes-scores-of-politicians /> accessed 21 October 2018.

409 With regard to this subject, Cavazotte et al. state that: "This investigation, initiated on March 2014, involved several national companies. As a result, seven of the ten largest Brazilian contractors had their executives investigated by the operation”. See Flavia Cavazotte, Marcos Cohen and Mariana Brunelli, 'Business Ethics in Brazil: Analyzing Discourse and Practice of the Brazilian Contractors Involved in Operation Lava Jato' in Christopher Stehr, Nina Dziatzko and Franziska Struve (eds), Corporate Social Responsibility in Brazil (Springer, Cham 2019) 251.

410 Melo (n 14) 60.

411 According to Moro: "Everything to do with the Lava Jato cases, from the prosecution, evidence, and hearing of witnesses to the judgment and sentencing, has been conducted openly and in the light of day". See Moro (n 31) 163.

412 Mello and Spektor (n 9) 113-114. 
tional acknowledgment. ${ }^{413}$ The recognition obtained by leniency policies is directly associated with their capacity to improve the prosecution of individuals and organizations that occupy central positions in society. ${ }^{414}$ Much of the Brazilian experience with leniency policies occurred under the banner of fighting the so-called "macro-delinquency, the delinquency of the powerful". ${ }^{415}$ Particularly in the context of "Operation Car Wash", collaboration agreements were used to investigate conducts committed by executives and shareholders of some of Brazil's largest business conglomerates, as well as acts committed by some of the country's major political leaders.

The difficulties of this type of investigations are well known. ${ }^{416}$ In corruption networks, criminal strategies are implemented through separate activities committed by multiple individuals at different times. ${ }^{417}$ These activities consist basically of ordinary business and administrative acts, integrated in the routines of legitimate organizations and indistinguishable from regular practices. ${ }^{418}$ The damages caused by the criminal conduct are diffuse and hard to associate with specific individual misbehavior, ${ }^{419}$ even when the losses are of enormous proportions. ${ }^{420}$ The fragmentation of criminal strategy generates a temporal, spatial and hierarchical distance between the occurrence of illegal acts and the organization's top brass in-

413 In 2016, for instance, the Operation Carwash Task Force was granted the AntiCorruption Award Transparency International. According to Transparency International Secretariat: "The ongoing Carwash Operation has triggered additional criminal investigations and proceedings in other sectors and is recognised as a landmark for white-collar criminal prosecution and defense in Brazil. The investigations have gained traction and huge popular support on both national and international levels". See 'Brazil Carwash Task Force Wins Transparency International Anti-Corruption Award' (n 19).

414 Sabine Kurtenbach and Detlef Nolte associated the Operation Car Wash with the "end of impunity" in Brazil, stating that "for the first time, top executives and high-ranking politicians were charged and convicted (and given lengthy prison sentences) by an independent judiciary and under pressure from civil society". See Kurtenbach and Nolte (n 16) 5.

415 In the words of Roland Hefendehl: Roland Hefendehl, 'Addressing White Collar Crime on a Domestic Level' (2010) 8 Journal of International Criminal Justice 769,782 .

416 On this subject, see item II.3.

417 Bannenberg (n 17) 108-110.

418 Katz (n 367) 436.

419 Lindemann (n 17) 127.

420 See item II.3.c. 
volved with its practice. ${ }^{421}$ In these circumstances, the establishment of criminal liability faces serious difficulties, especially regarding the leaders of the organization..$^{422}$

In this scenario, the 2013 rewarded collaboration regulation has often been portrayed as a necessary tool to bring about effective prosecution of powerful and resourceful offenders, ${ }^{423}$ especially in the field of corporate and governmental crimes. ${ }^{424}$ According to this view, the rewarded collaboration regulation, provided for in the Organized Crime Act, as well as the antitrust leniency program, established in the Competition Act, are part of a special subsystem in Brazilian law, one in which expediency, simplicity and efficiency are main vectors of state prosecution. ${ }^{425}$

On this point, the influence of the U.S. model of plea bargaining on the Brazilian experience with collaboration agreements is undeniable. ${ }^{426}$ Through the negotiation forum created by the Organized Crime Act, procedural participants developed a flexible and comprehensive system of transactions, creating consensually innovative solutions for various issues within criminal procedures. ${ }^{427}$ Collaboration agreements concluded at very early stages of the investigation defined the exact penalties of cooperators and detailed how it should be fulfilled, ${ }^{428}$ outlined new forms of imprisonment regimes, ${ }^{429}$ established a unified punishment for several conducts investigated in different procedures ${ }^{430}$ and created the possibility for

421 Shapiro (n 366) 354.

422 Greco and Leite (n 17) 290.

423 In this regard, see Lima (n 277) 305-308; Moro (n 31) 160, 166.

424 Multiple authors emphasize the importance of collaboration agreements in the investigation of these type of crimes. See e.g. Fonseca (n 98); Kurtenbach and Nolte (n 16) 5.

425 Nicolao Dino, 'A Colaboração Premiada Na Improbidade Administrativa: Possibilidade e Repercussão Probatória' in Daniel de Resende Salgado and Ronaldo Pinheiro de Queiroz (eds), A prova no enfrentamento à macrocriminalidade (2nd edn, Juspodivm 2016) 533.

426 Different authors note this influence. See, e.g., Silveira (n 35) 114-115. Criticizing the convergence between the Brazilian rewarded collaboration regulation and the American model of plea bargaining, see: Badaró (n 173).

427 Marcelo Cavali notes that "Several concluded agreements have established sanctions - detention regimes not provided for by law - to be served by cooperating defendants, without even the need of a judicial conviction. Thus, a mechanism similar to the American plea bargain was implemented in practice (...)". See Cavali (n 36) 262.

428 See section I.4.a.ii.

429 See section I.4.a.i.

430 See section I.4.a.iii. 
defendants to serve negotiated penalties, even imprisonment ones, before any judicial pronouncement on the verdict and sentence. ${ }^{431}$

The tailor-made negotiations gave rise to complex contractual arrangements between Federal Public Prosecution Office and cooperating defendants, drafted in several pages and with dozens of provisions, creating unique solutions for each case. This system of transactions was often justified on the ground that collaboration agreements were part of a new paradigm or a new model of criminal justice, in which the autonomy, the self-determination, and the consent of procedural participants played a central role. ${ }^{432}$ In this context, the U.S. system of plea bargaining has often provided a role model of an efficient criminal procedure, validating the innovations brought by this new form of "consensual justice" and the detachment from traditional principles of Brazilian criminal law, such as compulsory prosecution and strict legality. ${ }^{433}$

Based on these two pillars - (i) the visible results in the prosecution of macro-delinquency and (ii) the alleged harmonization with the international experience of consensual criminal justice - the Brazilian practice of collaboration agreements quickly gained ground. The confessions, reports and evidence offered by cooperating defendants generated tangible results, such as major recoveries of criminal proceeds and criminal convictions of individuals from Brazil's economic and political elite. Consensual arrangements boosted the progress of complex investigations and led to fast outcomes, in clear contrast to the traditional slow pace of the Brazilian justice

431 See section I.4.a.iv.

432 For a detailed analysis of this argument, see item I.4.c.

433 In this regard, a study of the Federal Prosecution Office affirmed the relevance of the American experience with consensual mechanisms for the Brazilian practice of collaboration agreements. See Ministério Público Federal, 'Estudo Técnico $n^{\circ}$ 01/2017' (n 279) 34. According to Andrey Borges de Mendonça: “The rewarded collaboration regulation imposes, therefore, a reflection about a new model of criminal justice, based on consensus. This model points - even in order to protect the traditional system - to the need of a reinterpretation of guarantees under the light of a due consensual criminal procedure. For that purpose, it is ideal to think of a new paradigm: the due consensual procedure". See Mendonça ( $\mathrm{n}$ 36) 59. Along the same lines, see the opinion issued by Min. Celso de Mello in Pet 7074, associating the rewarded collaboration with the emergence of "a new paradigm of criminal justice, in which the central element is the consensus of the participants of the criminal procedure." See STF, PET 7074 [2017] (Celso de Mello J). 
system. The achieved results were actively publicized by law enforcement authorities ${ }^{434}$ and attracted massive media attention. ${ }^{435}$

In this context, the advent of a new form of negotiated criminal justice, inspired by the U.S. system of plea bargaining and grounded in principles and concepts traditionally associated with private contract law, such as individual autonomy, legal certainty and protection of legitimate expectations, appeared as a reliable and efficient path to overcome the well-known problems of impunity in the Brazilian system of criminal justice, one that allowed for the effective prosecution of powerful white-collar offenders. ${ }^{436}$

\section{Conclusion: the will and the way for the practice of collaboration agreements}

The prosecution of corruption networks and business cartels is marked by structural constraints and high costs in the process of fact-finding and collection of evidence. ${ }^{437}$ The wrongful conduct is executed through interactions between criminals, which do not leave clearly identifiable losses or direct victims. ${ }^{438}$ The illegal transactions are carried out amidst the regular

434 The Federal Public Prosecution Office extensively promoted the results achieved in Operation Car Wash. According to a report of the Office: "(...) in order to promote transparency, the Federal Public Prosecution Office allowed the Brazilian society to check the technical and impartial work of the Institution. The Car Wash Operation website (www.lavajato.mpf.mp.br) contains the result of the work done by the Institution's members. The website has received more than 3 million views. To that, a professional interface with the national and international press was added. In the last 24 months, the Federal Prosecution Office has been asked to respond to 7.423 demands from press professionals, radio and TV stations, blogs and websites”. See Ministério Público Federal, 'Relatório de Resultados Do Procurador-Geral Da República: Diálogo, Unidade, Transparência, Profissionalismo, Efetividade: 2015-2017' (n 136) 13.

435 Based on the development of the treatment given by the media to corruption cases, Castro and Ansari state that "The press coverage of the Car Wash operation has received by far the largest corruption coverage in recent Brazilian history”. See Castro and Ansari (n 116) 358. According to the authors, the disclosure of information regarding the Operation was one of the fundamental elements to what they call "change in deviant institutionalized practices".

436 The link between the consensual nature of collaboration agreements and efficient prosecution of corporate crimes and corruption is a constant in Brazilian legal literature. See, among others, Fonseca (n 98) 125-129 and 212-215; Dino (n 426) 531-535; Sarmento (n 35) 452-453. Foreign authors, such as Kurtenbach and Nolte, also highlight this link: Kurtenbach and Nolte (n 16) 5.

437 See section II.3.

438 See item II.3.a. 
routines of legitimate organizations, often using sophisticated mechanisms of concealment and destruction of evidence. ${ }^{439}$

The strong social losses caused by this type of offense and the social standing held by their beneficiaries demand a detailed investigation of the facts and an imposition of penalties commensurate with the gravity of the wrongdoings. ${ }^{440}$ At the same time, the existence of serious obstacles to effective prosecution leads to recurrent situations of impunity. These different elements engender a scenario conducive to the use of leniency policies by public authorities, in order to address situations that combine the presence of severe damages and the existence of a serious enforcement deficit. ${ }^{441}$

Grounded on such circumstances, the Brazilian practice of collaboration agreements grew exponentially. ${ }^{442}$ Within a very short space of time, cooperation with offenders, which has never played an important role in Brazilian criminal justice, has undergone a huge expansion and become a central tool in the prosecution of conduct committed in the highest business and political circles, with enormous repercussions for Brazilian society. Due to the fast and visible results produced, collaboration agreements arose as an indispensable tool for addressing the problems of impunity of macrodelinquency in Brazil.

If the effective prosecution of corruption schemes and corporate wrongdoings provided the will for the massive use of collaboration agreements in Brazil, the ideal of a new system of negotiated justice provided the way. The concepts associated with a new paradigm of criminal proceeding, based less on the principles of legality and compulsory prosecution and

439 See item II.3.b.

440 See item II.3.c.

441 Writing on the use of cooperating defendants in German criminal law, Florian Jeßberger asserts that the combination of these two factors often lead to a scenario of "investigate emergencies" in the prosecution of corporate crimes, authorizing the granting of benefits to cooperating defendants. See Jeßberger, Kooperation Und Strafzumessung: Der Kronzeuge Im Deutschen Und Amerikanischen Strafrecht (n 1) 305. Also defending firmly the use of cooperating defendants in these investigations: Buzari (n 12). The concept of "investigate emergencies" and its implications will be examined in Chapter IV, particularly in section IV.3. On the issue, see: Andreas Hoyer, 'Die Figur Des Kronzeugen: Dogmatische, Verfahrensrechtliche Und Kriminalpolitische Aspekte' (1994) 49 JuristenZeitung 233, 239-240; and Heike Jung, 'Der Kronzeuge - Garant Der Wahrheitsfindung Oder Instrument Der Überführung?' (1986) 19 Zeitschrift für Rechtspolitik 38, 42.

442 See item I.2.b. 
more on the notions of autonomy, good faith and legal certainty, lent legitimacy to consensual arrangements that, until very recently, were inconceivable in Brazilian criminal procedure. ${ }^{443}$ Through an inventive and bold negotiation practice, procedural participants developed a broad and flexible system of transactions that is clearly detached from the statutory provisions of the Organized Crime Act, creating innovations such as new forms of detention regime and the possibility for cooperators to serve the negotiated imprisonment penalties in advance, before any judicial verdict has been rendered. ${ }^{444}$

The combination of the ostensible effectiveness of leniency policies in the prosecution of macro-delinquency and the theoretical appeal of consensual justice proved to be irresistible. In this context, the practice of collaboration agreements has flourished, gaining enormous media attention and solid support from the Brazilian judiciary, particularly from the Brazilian Federal Supreme Court. ${ }^{445}$ The following chapters carry out a more careful analysis of these two driving forces of the Brazilian practice of collaboration agreements.

443 See item I.4.c.

444 For a description of the inventive practice of collaboration agreements and its innovations, see item I.4.a and I.4.b.

445 See item I.4.c.i and I.4.c.ii. 


\section{Chapter III - Leniency policies: rationale, expectations and risks}

\section{Introduction}

In recent decades, anti-cartel policies have undergone what some authors call a "leniency revolution", ${ }^{446}$ an expression used to describe the great changes derived from the diffusion of legal mechanisms which allow the granting of benefits to cartel participants who cooperate with law enforcement authorities and denounce accomplices. ${ }^{447}$

Antitrust leniency programs were formally created in 1978, when the U.S. Department of Justice implemented its first leniency policy, the Corporate Leniency Policy. ${ }^{448}$ Under this program, cartel members who approached authorities to denounce criminal practices before the investigation was opened could be granted immunity from criminal prosecution and administrative penalties. In 1993, the Department of Justice decided to carry out a profound revision of its leniency programme, with the aim of increasing incentives and opportunities for the negotiation of agreements. ${ }^{449}$ The leniency policy was changed to ensure that the first company to come forward and report the existence of the cartel was automati-

446 According to Spagnolo, "The last ten years have witnessed what one could call, with little or no exaggeration, a revolution in competition policy and antitrust enforcement, 'the leniency revolution"'. See Spagnolo (n 30) 259.

447 Caron Beaton-Wells, 'Leniency Policies: Revolution or Religion?' in Caron Beaton-Wells and Christopher Tran (eds), Anti-cartel enforcement in a contemporary age: leniency policies (Hart Publishing 2015). Still on the subject of the "leniency revolution", Caron Beaton-Wells states that "Given their distinctiveness, proliferation and support, the adoption of leniency policies may be described as a 'revolution', a conceivably apt description in what has been referred to by enforcers as 'the war against cartels"' (ibid., 4).

448 Wils, 'Leniency in Antitrust Enforcement: Theory and Practice' (n 378) 213.

449 The revisions performed by the U.S. D.O.J. are recognized as a cornerstone in the use of leniency policies in the prosecution of cartels. See Motta and Polo ( $\mathrm{n}$ 29) 348; Margaret Levenstein and Valerie Y Suslow, 'Contemporary International Cartels and Developing Countries: Economic Effects and Implications for Competition Policy' (2004) 71 Antitrust Law Journal 801, 804-805. 
cally awarded full immunity from penalties. ${ }^{450}$ In addition, all the employees of the company who agreed to cooperate with the investigations would obtain immunity. ${ }^{451}$ The revised policy also enabled the use of leniency policies even if the investigation was already underway. ${ }^{452}$

After the 1993 revision, the average number of leniency applications went from one per year to two per month. ${ }^{453}$ By the early 2000s, U.S. authorities were already stating that the leniency program was the most important investigative mechanism, responsible for more cartel discoveries than all other mechanisms combined. ${ }^{454}$ The results obtained after the 1993 revisions greatly increased the importance of the leniency program in the U.S. cartel prosecution strategy, leading to the understanding by competition authorities that "leniency programs are the greatest investigative tool ever designed to fight cartels" 455 and gaining international recognition. ${ }^{456}$ Based on the revision of the leniency program conducted by the U.S. Department of Justice, ${ }^{457}$ various countries established mechanisms to enable full or partial reduction of penalties of cartel members who approached law enforcement authorities to report the offense and cooperate with investigations against former accomplices. In the first decade of the twenty-first century, more than 50 countries had already adopted leniency programs, forming a rather heterogeneous group of countries. ${ }^{458}$

Similar to what happened in the context of anti-cartel enforcement, there has also been, in the last decades, a clear movement in several countries towards expanding the use of leniency policies to investigate so-called

450 According to William E. Kovacic: "The new policy made clear that the first cartel member to seek leniency would receive complete immunity from criminal prosecution if it was truthful in its presentation to the DOJ and co-operated fully with the government's inquiry". See Kovacic, 'A Case for Capping the Dosage: Leniency and Competition Authority Governance' (n 378) 125.

451 Hammond, 'Cornerstones of an Effective Cartel Leniency Programme' (n 31) 10.

452 See O’Brien (n 31).

453 Bruce H Kobayashi, 'Antitrust, Agency, and Amnesty: An Economic Analysis of the Criminal Enforcement of the Antitrust Laws against Corporations' (2001) 69 The George Washington Law Review 715, 716.

454 Scott D Hammond, 'Detecting and Deterring Cartel Activity through an Effective Leniency Program', International Workshop on Cartels (DOJ 2000).

455 Hammond, 'Cornerstones of an Effective Cartel Leniency Programme' (n 31) 4.

456 Wils, 'Leniency in Antitrust Enforcement: Theory and Practice' (n 378 ) 214.

457 Joan-Ramon Borrell, Juan Luis Jiménez and Carmen Garcia, 'Evaluating Antitrust Leniency Programs' (2014) 10 Journal of Competition Law and Economics 107, 108.

458 O'Brien (n 31) 37. 
"organized crime" and other serious offenses. ${ }^{459}$ In this matter, too, the U.S. experience has played a very influential role, given that the specific characteristics of American criminal procedure - such as the wide discretion that procedural participants have in disposing of criminal cases - allowed cooperation with offenders to become a quite common reality in the U.S. justice system. ${ }^{460}$ The granting of benefits to offenders who expose other perpetrators and provide information and evidence to law enforcement authorities is an established practice, which has strong foundations in the American legal system and is widely used in the prosecution of different forms of crime. ${ }^{461}$

In countries integrated into the Continental tradition, the negotiation of leniency agreements with offenders has historically been limited by the traditional structure of criminal procedure, in particular by the principle of compulsory prosecution or legality, which requires prosecutors to file charges whenever there is sufficient evidence of the commitment of a crime, reducing the room for negotiation in criminal proceedings. 462 Notwithstanding these obstacles, at the end of the twentieth century multiple continental tradition countries had adopted regulations that expressly provided for preferential treatment for cooperating offenders. ${ }^{463}$

In 1991, Italy passed legislation allowing the granting of benefits to individuals who confessed their crimes and helped public authorities to reconstruct the facts and to hold other members of the criminal organization to account for their crimes. ${ }^{464}$ In Germany, the legislation to combat drug trafficking was revised in 1982 to allow this kind of benefit, and subse-

459 Fyfe and Sheptycki (n 1) 320.

460 Florian Jeßberger notes that "in the United States cooperation with offenders is a part of the daily routine of criminal procedure. According to the author, "Supported by the wide freedom of the procedural participants to dispose of the object and the course of a criminal proceeding, the trade of cooperation in the conviction of third parties for leniency in the own punishment has been for a long time a disseminated practice". See Jeßberger, Kooperation Und Strafzumessung: Der Kronzeuge Im Deutschen Und Amerikanischen Strafrecht (n 1) 21-22.

461 Weinstein (n 3) 564 and 569.

462 After analyzing the American experience in the prosecution of corporate crimes, Ana Marra Neira Pena asserts that "the situation in continental countries is very different (...)". One of the main reasons for this difference is that "the principle of legality prevents prosecutors from not bringing charges when a crime has been committed. Therefore, the power to negotiate agreements is more reduced, at least in theory”. See Neira Pena (n 375) 205.

463 Peter Tak mention the legal scenario of countries such as Italy, Germany, Holland, France and Spain. See Tak (n 4).

464 Musco (n 346) 35. 
quent legal reforms expanded the possibility of granting favored treatment to cooperating defendants in the prosecution of other types of crimes. ${ }^{465}$ Over recent decades, the use of cooperation with offenders has become a common mechanism in the prosecution of serious offenses in several European countries. ${ }^{466}$

The recent growth of leniency policies in Brazil has taken place in a context of alignment with foreign legal practices. Reference to international treaties and to the experience of other countries has regularly been employed to support and validate the introduction and development of Brazilian leniency policies. ${ }^{467}$ Foreign experiences, in particular from the United States, are commonly used to demonstrate the usefulness of cooperation with offenders in achieving a more efficient system of justice, especially to overcome problems of impunity in certain fields of criminality. ${ }^{468}$ In this context, the Brazilian development of leniency policies occurred both in competition law and criminal law - under the clear influence of the American experience, as has also happened in other countries. ${ }^{469}$

This chapter presents a more nuanced portrait of leniency policies, especially in the field of white-collar crime, drawing on a growing body of literature that examines and tests the effects of these policies from various perspectives. In the face of the growing importance of leniency policies in

465 For a description of this evolution, see item IV.3.a.

466 Fyfe and Sheptycki (n 1) 339.

467 For an example in the jurisprudence of the Brazilian Federal Supreme Court, see STF, HC 127483 [2015].

468 On this points, a 2017 report of the Brazilian Federal Public Prosecution Office defended the need of a "new comprehension" of the Brazilian criminal justice, "in order to adjust it to new paradigms, adopted by the influence of the common law systems of the Anglo-Saxon legal order, in which there is no commitment to the principle of compulsory prosecution in the activities of the law enforcement authorities (...)”. See Ministério Público Federal, 'Estudo Técnico no $01 / 2017$ ' (n 279) 34.

469 Examining the German experience, Klaus Malek asserts critically that the introduction and development of leniency policies in criminal law reflect a wider trend of "americanization" of the German criminal procedure, stating that the example set by the United States is fundamental to validate the cooperation between offenders and enforcement authorities. See Klaus Malek, 'Abschied von Der Wahrheitssuche' (2011) StV 559, 566. Recognizing the American influence in the development of leniency policies worldwide, Ann $\mathrm{O}^{\prime}$ Brien states that the United States Department of Justice (DOJ) is the "undisputed market leader of leniency" and that "DOJ prosecutors preached the benefits of leniency, and the members of the bar, the business community and cartel enforcers around the world listened and followed suit". See O'Brien (n 31) 15. 
different countries, an abundance of literature has emerged, which threw light on interesting - and often unnoticed - aspects of these mechanisms. Section III.2 describes the rationale of leniency policies as tools designed to maximize deterrence, analyzing the expectations of increased detection and prevention of organized crime. Section III.3 examines different side effects resulting from leniency policies, such as the risk of an erroneous factfinding, the negative impact on the level of penalties and the possible strategic exploitation by offenders. Section III.4 closes the chapter analyzing the appropriateness of the ideal of a "leniency revolution", contrasting it with the critical notion of a "leniency religion".

\section{The rationale and expectations of leniency policies: optimal deterrence through increased detection and prevention}

At the end of the twentieth century, multiple countries underwent profound reform in their criminal justice system, through changes - in both substantive and procedural law - that sought to give greater effectiveness to the actions of law enforcement authorities in the control of new forms of crimes. ${ }^{470}$ One of the characteristics of this movement is the enlargement of the range of mechanisms at disposal of law enforcement authorities for investigating increasingly sophisticated criminal strategies, in what can be perceived as an inverted reading of the principle of equality of arms. ${ }^{471}$ In this context, a clear tendency, both in Europe and globally, was the formulation of mechanisms allowing law enforcement authorities to

470 Describing a movement of "modernization of criminal law", Winfried Hassemer speaks of "new areas, instruments and functions" assumed by criminal law in the last decades of the $20^{\text {th }}$ century. See Hassemer (n 365) 382.

471 Joachim Vogel notes the dispute regarding the concept of the principle of equality of arms in the German debate of reform of criminal procedure. According to the author, the traditional view demands the improvement of the position of the accused before state organs; an alternative - more recent - view requests the empowerment of enforcement authorities to investigate sophisticated criminal organizations that act without the restrictions normally imposed upon public officials. See Joachim Vogel, 'Chancen Und Risiken Einer Reform Des Strafrechtlichen Ermittlungsverfahrens' (2004) 59 JuristenZeitung 827, 830. For a harsh criticisim of the idea of equality of arms between enforcement authorities and organized crime, see: Edda Weßlau, 'Waffengleichheit Mit Dem »Organisierten Verbrechen «? Zu Den Rechtsstaatlichen Und Bürgerrechtlichen Kosten Eines Anti-OK-Sonderrechtssystems' (1997) 80 Kritische Vierteljahresschrift für Gesetzgebung und Rechtswissenschaft (KritV) 238. 
cooperate with offenders to investigate serious crimes. ${ }^{472}$ Such mechanisms received different names in domestic criminal legislations, such as "Kronzeuge" in Germany, "collaboratore della giustizia" and "pentito" in Italy, "kroongetuige" in Netherlands, "supergrass" in the United Kingdom and "repenti" in France. ${ }^{473}$

Also in the field of competition law, there has recently been a significant increase in the use of cooperation with offenders to enhance the effectiveness of anti-cartel enforcement. ${ }^{474}$ After the successful reform of U.S. Department of Justice's leniency policy in 1993, the European Commission adopted its first leniency program in 1996 and, soon afterwards, European countries enacted their own leniency regulations. ${ }^{475}$ Nowadays, dozens of countries have introduced recent legislation authorizing law enforcement authorities to cooperate with cartel participants in investigations against other members of anti-competitive practices. ${ }^{476}$

Although there are clearly a number of differences between these mechanisms, which acquire peculiar characteristics according to the specificities of each legal system, their mode of operation follows the same logic: confessed offenders assist law enforcement authorities in the prosecution of offenses committed by other perpetrators in exchange for benefits. 477 These mechanisms are aimed at investigating wrongdoings committed through joint efforts of several agents and are designed to promote distrust and defection in criminal organizations. ${ }^{478}$ A central element of leniency policies is that they allow a subject, who is himself guilty of a wrongdoing, to assist

472 Fyfe and Sheptycki (n 1) 320.

473 Tak (n 4) 2.

474 For a good description of the so-called "leniency revolution" in antitrust, see: Spagnolo, 'Leniency and Whistleblowers in Antitrust' (n 30).

475 Wouter Wils observes the key role played by the American example in the dissemination of leniency policies worldwide. According to the author, the 1996 leniency program of the European Commission

"was clearly inspired by the US Department of Justice's Corporate Leniency Policy of 1993". Furthermore, "the leniency programmes in the EU Member States have generally been adopted following the example of the European Commission, and thus indirectly of the US Department of Justice". See Wils, 'Leniency in Antitrust Enforcement: Theory and Practice' (n 378) 214-215.

476 According to Ann $\mathrm{O}^{\prime}$ Brien, over the last decades more than 50 countries have adopted leniency policies to investigate cartels. See O'Brien (n 31) 37.

477 Several authors have noted the similarities between the use of leniency policies in criminal and competition law. See Buccirossi and Spagnolo (n 29); Acconcia and others (n 29); Buzari (n 12).

478 On the resemblance between the different types of illicit behavior investigated through leniency policies, Reinaldo Diogo Luz and Giancarlo Spagnolo assert 
in the prosecution of illegal acts committed by other agents with the objective of gaining legal benefits. ${ }^{479}$

Leniency policies are developed through a relationship of voluntary exchange between offenders and law enforcement authorities. ${ }^{480}$ For both sides involved in the exchange, this relationship is formed with the expectation that the cooperative behavior by one of the parties will be followed by a similar attitude from the other side. ${ }^{481}$ The cooperative behavior of the offender does not derive from selflessness, but rather from an interest in achieving certain benefits, which generally consist of either amnesty or a reduction in penalties, but may also take other forms. ${ }^{482}$ The objective of leniency policies is to obtain voluntary cooperation from offenders, leading to situations in which the relationship between defendants and public authorities loses some of its vertical character and acquires properties similar to private exchanges. ${ }^{483}$

Leniency policies are based on the creation of an incentive system, which allows the offender to perceive a more favorable outcome from cooperating with the investigations than from continuing to participate in the criminal organization. An essential element of this system of incentives is the differential treatment granted to the cooperating offender, when

that: "Cartels, corruption, and many other types of multiagent offenses depend on a certain level of trust among wrongdoers, which is precisely what leniency programs aim to undermine by offering incentives for criminals to betray their partners and cooperate with the authorities". See Luz and Spagnolo (n 81) 6.

479 Florian Jeßberger calls this the "leniency model" ("Modell Kronzeuge") and asserts that this model of cooperation between public officials and defendants has some specific characteristics that differentiate it from other cooperative behaviors that exist within a system of law enforcement. See Jeßberger, Kooperation Und Strafzumessung: Der Kronzeuge Im Deutschen Und Amerikanischen Strafrecht (n 1) 25-32.

480 Klaus Malek, 'Die Neue Kronzeugenregelung Und Ihre Auswirkungen Auf Die Praxis Der Strafverteidigung' (2010) StV 200, 203.

481 Lorenz Nicolai Frahm, Die Allgemeine Kronzeugenregelung: Dogmatische Probleme Und Rechtspraxis Des $\mathbb{4} 46 b$ StGB (Duncker \& Humblot 2014) 128.

482 JH Crijns, MJ Dubelaar and KM Pitcher, Collaboration with Justice in the Netherlands, Germany, Italy and Canada (Universiteit Leiden 2017) 25.

483 Harding, Beaton-Wells and Edwards speak of "a process of business-like negotiation rather than top-down interrogation”. See Christopher Harding, Caron Beaton-Wells and Jennifer Edwards, 'Leniency and Criminal Sanctions in AntiCartel Enforcement: Happily Married or Uneasy Bedfellows?' in Caron BeatonWells and Christopher Tran (eds), Anti-cartel enforcement in a contemporary age: leniency policies (Hart Publishing 2015) 253. 
compared to other non-cooperative defendants. ${ }^{484}$ Such differentiation consists, on one hand, in offering advantages to offenders who choose to cooperate and, on the other hand, in the strict penalization of those who choose not to. ${ }^{485}$ Through leniency policies, public authorities seek to place offenders in the situation known as the prisoner's dilemma, in which the cooperative behavior of an offender, while bringing benefits to the cooperator, is detrimental to the other accused. ${ }^{486}$

The cooperation of defendants obtained through leniency policies is, therefore, based primarily on utilitarian calculations, aimed at determining what types of benefits can be obtained through the use of this mechanism. ${ }^{487}$ There is no expectation of actual repentance from the offender regarding the acts committed and to the damages caused. ${ }^{488}$ What is required is the adoption of a cooperative stance - mainly through the provision of evidence and information - that effectively contributes to investigations of crimes committed by third parties. ${ }^{489}$

Also from the point of view of public authorities, the utilitarian nature of leniency policies is clear. From this perspective, the granting of benefits to cooperating offenders is strictly based on criminal policy considerations and practical reasons. ${ }^{490}$ Leniency policies are instruments for achieving a specific objective: to assist law enforcement authorities in controlling certain crimes, in particular organized crime. ${ }^{491}$ The focus of leniency policies is to increase efficiency in the control of criminal structures in modern so-

484 Jeßberger (n 2) 1161-1162.

485 According to Ann O'Brien, it is a “'carrot and stick' enforcement strategy”. See O'Brien (n 31) 16.

486 Christopher R Leslie, 'Antitrust Amnesty, Game Theory, and Cartel Stability' (2006) 31 The Journal of Corporation Law 453, 455-457.

487 Colombo (n 383).

488 Malek, 'Die Neue Kronzeugenregelung Und Ihre Auswirkungen Auf Die Praxis Der Strafverteidigung' (n 481) 201.

489 Stefanie Mehrens asserts that the differential treatment obtained under leniency policies stems from the defendant's capacity to effectively contribute to the investigation of crimes committed by other agents, and not from the reduction of the damages caused by his own acts. See Mehrens (n 11) 33-35.

490 Musco (n 346) 38.

491 Crijns, Dubelaar and Pitcher highlight this aspect, asserting that: "collaboration with justice can be viewed as an instrument which serves a specific purpose, i.e. helping to combat organised and other forms of crime". See Crijns, Dubelaar and Pitcher (n 483) 29. 
ciety, ${ }^{492}$ preventing the impunity that derives from the ineffectiveness of traditional investigative tools in certain fields of criminality. ${ }^{493}$

Thus, the employment of leniency policies is justified, for offenders and public authorities alike, insofar as it allows the achievement of better results within the criminal proceeding. From the point of view of the offender, leniency policies enable the creation of more favorable legal situations, especially by reducing or extinguishing penalties. On the part of the authorities, the benefits associated with the use of leniency policies are normally divided into two categories. ${ }^{494}$ Firstly, such policies increase the state's capacity to collect relevant information and evidence to solve serious crimes and prosecute offenders. Secondly, such mechanisms play a role in the prevention of criminal conduct, devising obstacles that hinder or prevent the execution of criminal strategies.

\section{a. Detection of crimes and gathering of evidence}

A central objective sought by leniency policies is the reduction of the informational and evidentiary deficit faced by law enforcement authorities when prosecuting certain types of criminal behavior. ${ }^{495}$ In view of the challenges imposed by new forms of wrongdoing, in particular organized crime, these mechanisms seek to restore the state's capacity to detect offenses and identify offenders. ${ }^{496}$ In this context, leniency policies appear as

492 Jens Peglau, 'Überlegungen Zur Schaffung Neuer „Kronzeugenregelungen“" (2001) 34 Zeitschrift für Rechtspolitik 103, 105.

493 Frahm (n 482) 185-186.

494 Different authors analyze these two categories separately. Ellen Schlüchter speaks of "direct effects" and "indirect effects" of leniency policies. See Ellen Schlüchter, 'Erweiterte Kronzeugenregelung?' (1997) 30 Zeitschrift für Rechtspolitik 65, 68. Motta and Polo draw a distinction between the effects of a leniency policy on desistence and on deterrence. Massimo Motta and Michele Polo, Leniency programs and cartel prosecution. On a similar note, Wouter Wils differentiate between detection and deterrence. See Wils, 'Leniency in Antitrust Enforcement: Theory and Practice' (n 378) 227-229.

495 Jeßberger (n 1) 27-29.

496 Defending the use of cooperating defendants in German criminal law, Ellen Schlüchter argues that new forms of criminal structures - specially related to terrorism and organized crime - create situations of emergency that threaten the rule of law, requiring the development of effective answers. See Schlüchter (n 495) 71. On a similar vein, regarding the Italian experience, see Musco (n 346) 38 . 
tools employed to overcome investigative difficulties arising from the commitment of serious crimes through hermetic structures and complex conspiracies ${ }^{497}$ which plan and execute criminal strategies using active techniques of concealment and destruction of evidence. ${ }^{498}$

In order to obtain information and evidence about crimes characterized by high levels of professionalism, there are essentially two paths that law enforcement authorities may follow. ${ }^{499}$ On the one hand, they may develop their own investigative tools, such as wiretapping or undercover agents. On the other, they may resort to the cooperation of private agents, whether individuals or corporations, with access to the elements necessary for conducting an effective prosecution.

Leniency policies fall into the latter category and exploit a characteristic of criminal organizations that allows state authorities to obtain information and evidence directly from offenders. The formation of criminal organizations, while enabling the commission of more serious and sophisticated crimes, also requires coordination of activities between multiple individuals. $^{500}$ Therefore, organized criminal activities create situations where each participant has, to a certain degree, information and evidence that is useful for the prosecution of other offenders. ${ }^{501}$ In criminal organizations, the offender perceives their alliance with co-conspirators as a means to illegally gain financial advantages; leniency policies enable the offender to understand cooperation with public authorities as a means of obtaining legal benefits, in particular immunity from penalties..$^{502}$

497 Frahm (n 482) 31.

498 Harding, Beaton-Wells and Edwards (n 484) 358.

499 Jeßberger, Kooperation Und Strafzumessung: Der Kronzeuge Im Deutschen Und Amerikanischen Strafrecht (n 1) 19-20.

500 Paolo Biccirossi and Giancarlo Spagnolo notes that organized illegal transactions demand coordinated action between different agents and bring about situations prone to opportunistic behavior: "Since illegal transactions involve at least two parties and require trust among them-their potential opportunism cannot be limited by court-enforced contracts-one way law enforcement agencies traditionally fight them is undermining trust by shaping incentives to play one party against the other(s): ensuring that they find themselves in a situation as close as possible to a Prisoner's Dilemma. Law enforcers do this by awarding leniency - typically a reduction or cancellation of legal sanctions accompanied by protection from retaliation and related benefits-to wrongdoers that self-report helping to convict 'the rest of the gang'". See Buccirossi and Spagnolo (n 29) 1282.

501 Spagnolo (n 30) 262.

502 Hoyer (n 442) 235. 
Proximity to the criminal conduct gives the offender privileged knowledge about it, ${ }^{503}$ which could not be easily obtained by other investigative mechanisms. The use of this insider knowledge gains special significance in situations where criminal activities cause serious damage to society and are carried out in a sophisticated manner, preventing effective prosecution through traditional investigative tools. ${ }^{504}$ The commission of crimes by means of organized structures can create scenarios in which law enforcement authorities have enormous difficulty in ensuring the effective enforcement of criminal standards. ${ }^{505}$ In this context, the granting of benefits to offenders who cooperate with the investigations is a necessary, albeit extreme, measure for the collection of evidence about certain types of criminal conduct. ${ }^{506}$

In hierarchical criminal structures, obtaining information from an internal source is often essential for imposing criminal liability upon the leaders of the organization. ${ }^{507}$ In the structures of contemporary society, offenses are often committed within organizations, with several individuals contributing - at different levels and with varying degrees of control - to the criminal strategy. ${ }^{508}$ Given the internal division of functions at various levels, it is extremely difficult to link the offense to the main beneficiaries of the crime. ${ }^{509}$ Cooperation with offenders enables law enforcement authorities to understand the structure of the criminal organization and to obtain, from an internal source, the evidence needed to hold its leaders accountable. ${ }^{510}$ In large-scale investigations, the use of cooperation mechan-

503 Jeßberger, 'Nulla Poena Quamvis in Culpa: Ammerkungen Zur Kronzeugenregelung in $\$ 46$ StGB' $\left.^{(n)} 2\right) 1164$.

504 Schlüchter (n 495) 69-71.

505 In German criminal law, Andreas Hoyer has famously called these situations "investigative emergencies" ("Ermittlungsnotstand"). See Hoyer (n 442) 235-240.

506 Jung (n 442) 42.

507 Acconcia and others (n 29) 1122.

508 Joachim Vogel cites three fields of criminality in which the problem of determining individual criminal responsibility arises with particular force: "economic and environmental crime which is typically committed within the framework of companies; organized crime which is committed within the framework of criminal organisations; and last but not least «state crime» which is committed within the framework of governments, armies, police bodies, bureaucracies etc”. See Joachim Vogel, 'How to Determine Individual Criminal Responsibility in Systemic Contexts: Twelve Models' (2002) Cahiers de Défense Sociale 151, 151.

509 Colombo (n 383) 511.

510 Tak (n 4) 2. 
isms may lead to the imposition of liability on individuals who seemed distant from the conduct originally investigated. ${ }^{511}$

In the field of white-collar criminality, where the simultaneous presence of strong investigative obstacles and potential damages creates a high dark figure, ${ }^{512}$ the use of leniency policies can contribute decisively to effective prosecution. ${ }^{513}$ The investigation of cartels and corruption networks is particularly problematic, since in both situations the damages caused by the crimes are diffuse and rarely felt by individuals. ${ }^{514}$ Unlike other offenses where the identification of victim and the assessment of damages are obvious, these offenses are structured on offender-offender relationships ("Täter-Täter-Beziehungen"), 515 which generally do not leave any detectable traces. In addition, such illegal behavior is usually committed within sophisticated corporate organizations and camouflaged within a large group of ordinary and legitimate business acts. ${ }^{516}$

The combination of these characteristics leads to a scenario where the costs of investigating corruption networks and cartels are quite high when compared to other offenses. ${ }^{517}$ The absence of obvious criminal behavior, the fact that the evidence of the offense remains in the hands of the perpetrators and the employment of organizational routines that mask the illegal strategy all hinder the efforts of law enforcement authorities. ${ }^{518}$

Reactive investigative mechanisms, generally used in the investigation of traditional forms of crimes, are rarely effective in the prosecution of these offenses. In the prosecution of cartels, leniency policies are an essential source of information for antitrust authorities regarding the existence of anticompetitive conspiracies, since the other two options - the monitoring of markets and obtaining information from third parties - are of little

511 Letizia Paoli, 'Mafia and Organised Crime in Italy: The Unacknowledged Successes of Law Enforcement' (2007) 30 West European Politics 854, 863.

512 Jeßberger, Kooperation Und Strafzumessung: Der Kronzeuge Im Deutschen Und Amerikanischen Strafrecht (n 1) 305.

513 For a strong defense of the use of cooperating defendants in the investigation of economic crimes, see: Buzari (n 12) 112-114. According to the author, ,this field of criminality is known for the notorious huge dark figure"; furthermore, individuals responsible for these wrongdoings, are distinguishedly suitable for becoming cooperating defendants", due to their rational behavior.

514 Lindemann (n 17) 127.

515 Lindner (n 368) 67.

516 Katz (n 367) 436

517 For a more detailed analysis of these issues, see section II.3. Similarly, Martín (n 23).

518 Shapiro (n 366) 1. 
avail. ${ }^{519}$ While market monitoring may indeed reveal suspicious corporate moves, it is generally insufficient to provide a firm basis for the implementation of more severe investigative measures, given that such moves may stem from a variety of causes other than the formation of a cartel. $.^{520} \mathrm{Com}-$ plaints brought by third parties - customers and competitors harmed by the cartel - often mistake legal for illegal practices and present little information capable of clearly establishing the existence of an anticompetitive collusion. Corruption networks arise, likewise, from closed conspiracies, which benefit all the participants with knowledge of the crimes committed, while trying to avoid the existence of disinterested witnesses and written evidence. ${ }^{521}$

In this framework, characterized by enormous difficulty in detecting the damages caused by corruption schemes and cartels and in identifying those responsible for the offenses, ${ }^{522}$ the introduction of leniency policies establishes a new tool for accessing information and evidence that may be extremely relevant. With the information and knowledge provided by the cooperator, all the sophistication employed to conceal the crimes may suddenly become ineffective. In many cases, cooperation with offenders enables law enforcement authorities to understand the functioning of criminal organizations, identifying hitherto unsuspicious operations, the role of each agent involved and the existence of preparatory and subsequent offenses. 523

b. Prevention of illegal activities

In addition to enhancing the capacity of law enforcement authorities to detect wrongdoing, leniency policies also play a role in the prevention of

519 Wouter PJ Wils, 'The Use of Leniency in EU Cartel Enforcement: An Assessment after Twenty Years' (2016) 39 World Competition: Law and Economics Review 327.

520 For a good examination of the difficulties of ex officio investigations in anti-cartel enforcement, but defending their importance, see Hans W Friederiszick and Frank P Maier-Rigaud, 'Triggering Inspections Ex Officio: Moving beyond a Passive EU Cartel Policy' (2008) 4 Journal of Competition Law and Economics 89.

521 Lejeune (n 12) 87-88. Similarly: Nagel (n 341) 33.

522 Greco and Leite points out that evidentiary challenges constitute a "constant problem in the prosecution of corporate and state wrongdoing". See Greco and Leite (n 17) 290.

523 Colombo (n 383) 511. 
illegal transactions, through the creation of disincentives and expansion of inherent obstacles in criminal organizations and cartels. Criminal organizations are collaborative endeavors developed through the coordinated action of multiple offenders who need to trust each other. ${ }^{524}$ In this respect, such organizations resemble legitimate joint ventures and face the same challenges to cooperation: how to create rules and enforcement mechanisms for the development of productive and stable relationships? ${ }^{525}$

However, since it is not possible to draw on the justice system to solve internal disputes, these organizations have an inherent problem of enforcement of the illegal transactions made between offenders. ${ }^{526}$ Thus, criminal organizations create numerous occasions for opportunistic behavior, which can only be controlled through internal mechanisms. ${ }^{527}$ This situation is especially problematic because a breach of an illegal transaction can ensure great benefits for the cheating offender. In corruption, for example, it is possible that the agent refuses to fulfill his or her part of the illicit deal after receiving their illegal benefit. ${ }^{528}$ Likewise, the breach of a cartel agreement makes it possible for a company to benefit from higher market prices, while at the same time increasing its market share, by charging below the cartel price.

524 Maria Bigoni and others, 'Trust, Leniency, and Deterrencey' (2015) 31 Journal of Law, Economics, and Organization 663, 663-664.

525 Christopher R Leslie, 'Trust, Distrust and Antitrust' (2004) 82 Texas Law Review 515, 546.

526 Andreas Stephan and Ali Nikpay, 'Leniency Decision-Making from a Corporate Perspective: Complex Realities' in Caron Beaton-Wells and Christopher Tran (eds), Anti-Cartel Enforcement in a Contemporary Age: Leniency Policies (Hart Publishing 2015).

527 Michele Polo, 'Internal Cohesion and Competition among Criminal Organisations' in Gianluca Fiorentini and Sam Peltzman (eds), The Economics of Organised Crime (Cambridge University Press 1995).

528 Giancarlo Spagnolo highlights that different organized illegal activities, such as corruption and cartels, share a common feature that "cooperation among several agents is required to perform the illegal activity, so problems of free-riding, holdup, moral hazard in teams, and opportunism in general become relevant: each individual wrongdoer could "run away with the money" and must be prevented from doing it. This "governance problem" cannot be solved in standard ways in illegal organizations because - to curb opportunism of its individual members and ensure internal cooperation-these cannot rely on explicit contracts enforced by the legal system, as do legal organizations”. See Spagnolo (n 30) 261. 
This creates a scenario prone to the use of violence as a way of ensuring that members of the criminal organization fulfill their obligations. ${ }^{529}$ In many situations, however, resorting to violence as a mechanism to guarantee the fulfillment of illegal transactions is not feasible. In addition to being costly, violence often draws the attention of public authorities and jeopardizes the reliability of the illicit transactions. ${ }^{530}$ In the context of white-collar crime - in which the illegal activities occur within legitimate business structures - aversion to such methods tends to be even greater. For this reason, trust is a central element to the formation and maintenance of criminal organizations, ${ }^{531}$ especially in the field of economic and corporate crime. ${ }^{532}$ It is this mutual confidence that other participants of the illicit enterprise will fulfill their obligations that makes the development of criminal strategies possible, even when they involve high risks for their members. ${ }^{533}$

In this context, a central expectation regarding the use of leniency policies is an increase in distrust among members of the criminal organization. ${ }^{534}$ By enhancing instability, leniency policies seek to indirectly inhibit the formation and maintenance of criminal organizations. Leniency pol-

529 Examining the presence of the Italian mafia in legitimate industries, Gambeta and Reuter argue that "the mafia solves a problem of potential cartels. (...). Its comparative advantage is likely to be in organising cartel agreements for large number industries, as well as making cartels more stable (...) Moreover, the mafia has a unique asset in this capacity, namely its reputation for effective execution of threats of violence; this creates a reputational barrier to entry". See Diego Gambetta and Peter Reuter, 'Conspiracy among the Many: The Mafia in Legitimate Industries' in Gianluca Fiorentini and Sam Peltzman (eds), The Economics of Organised Crime (Cambridge University Press 1995).

530 JD Jaspers, 'Managing Cartels: How Cartel Participants Create Stability in the Absence of Law' (2017) 23 European Journal on Criminal Policy and Research 319.

531 For a detailed analysis of the concept and role of trust in criminal organizations, see Klaus von Lampe and Per Ole Johansen, 'Organized Crime and Trust: On the Conceptualization and Empirical Relevance of Trust in the Context of Criminal Networks' (2004) 6 Global Crime 159, 176-177. According to the authors, "trust is an empirically and theoretically significant variable for understanding organized crime, but it is a multifaceted phenomenon which stands in the way of easy explanations."

532 According to Leslie: "Cartels are simply another type of business relationship, albeit an illegal one. Like more traditional business relationships, cartels depend on trust”. See Leslie (n 526) 547.

533 Gambetta and Reuter (n 530) 117.

534 Strongly defending the need to employ cooperating defendants in the investigation of government corruption, Stefanie Lejeune asserts that "the use of lenien- 
icies create a number of advantages for members of criminal organizations that were previously unattainable, distorting the balance between the expected gains from the illegal activity and the benefits received through opportunistic behavior against the interests of the organization. ${ }^{535}$

Leniency policies thus generate a new structure of incentives that intensifies conflictsnaturally present in criminal organizations. ${ }^{536}$ In addition to the inherent problems of enforcing illegal transactions, these organizations start to face the constant possibility that one of their members will abandon the illicit enterprise to denounce others and obtain leniency benefits. By heightening the instability of criminal organizations, leniency policies increase the private costs incurred by members of a criminal organization and make the maintenance of illegal schemes even more costly. With the introduction of legal possibilities for cooperation with enforcement authorities, participants have to deal with the permanent option of being rewarded for betraying the organization and the constant risk of someone else doing it first.

For this reason, leniency policies have also an important role in the prevention of illegal activities, and not only in the detection of wrongdoings. ${ }^{537}$ Faced with greater risk of opportunistic behavior by their accomplices, a potential offender may simply decide not to enter a criminal organization to avoid being denounced by another member. ${ }^{538}$ On this point, leniency policies are in line with contemporary trends in the prosecution of corporate criminality, which seek to prevent illegal practices before they are committed, and not just punish them after they occur. ${ }^{539}$ In leniency policies, the goal of prevention is achieved through the erosion of an essential element for the practice of organized crimes: trust among offenders. In this manner, these policies can be seen as part of a wider initiative to re-

cy policies is in cases of corruption indispensable, in order to dismantle criminal interconnections and to create the necessary incentives for those individuals willing to cooperate with the law enforcement official". See Lejeune (n 12) 88.

535 Harrington Jr. (n 29) 217.

536 Antonio Acconcia and others, 'Accomplice Witnesses and Organized Crime: Theory and Evidence from Italy' (2014) 116 Scandinavian Journal of Economics 1116, 1118.

537 According to Ellen Schlüchter, this preventive effect of leniency policies tends to be underestimated. See Schlüchter (n 495) 68.

538 Leslie (n 526) 552.

539 For an interesting description of these trends, see Hefendehl, 'Außerstrafrechtliche Und Strafrechtliche Instrumentarien Zur Eindämmung Der Wirtschaftskriminalität' (n 12) 828-838. 
duce corporate criminality through the early elimination of certain conditions favoring illegal behavior. ${ }^{540}$

\section{Principal-agent relationships, information asymmetry and the risks of leniency policies}

The spread of leniency policies across the globe has been accompanied by clear advocacy efforts, promoted by enforcement agencies and disseminated through international channels. A central element in the recent development of leniency policies was the strong support given by multilateral organizations, which can be clearly perceived in both competition and criminal law. In the field of anti-cartel enforcement, the introduction of leniency policies is strongly supported by organizations such as the Organization for Economic Cooperation and Development (OECD), ${ }^{541}$ the International Competition Network (ICN) ${ }^{542}$ and the United Nations Conference on Trade and Development (UNCTAD). ${ }^{543}$ In the realm of criminal prosecution, the United Nations Convention against Transnational Organized Crime, signed in Palermo in 2000, recommends that signatory States

540 Other examples of this wider trend can be seen in the legal requirements regarding the development of compliance programs and systems of corporate governance. For a critical view of these mechanisms, see

Roland Hefendehl, 'Corporate Governance Und Business Ethics: Scheinberuhigung Oder Alternativen Bei Der Bekämpfung Der Wirtschaftskriminalität?’ (2016) 61 JuristenZeitung 119.

541 Regarding the antitrust leniency programs adopted by various jurisdictions, the OCDE understands: "The programs uncover conspiracies that would otherwise go undetected. They elicit confessions, direct evidence about other participants, and leads that investigators can follow for other evidence too. The evidence is obtained more quickly, and at lower direct cost, compared to other methods of investigation, leading to prompt and efficient resolution of cases". See OECD, 'Fighting Hard-Core Cartels: Harm, Effective Sanctions and Leniency Programmes' (2002) 11.

542 For the description of the benefits associated with the introduction of leniency policies, see ICN, 'Anti-Cartel Enforcement Manual' (2014) 4-5.

543 On this subject, the UNCTAD Conference states that "(...) the most effective tool today for detecting cartels and obtaining the relevant evidence is leniency programmes". See UNCTAD, 'The Use of Leniency Programmes as a Tool for the Enforcement of Competition Law against Hardcore Cartels in Developing Countries', Sixth United Nations conference to review all aspects of the set of multilaterally agreed equitable principles and rules for the control of restrictive business practices (2010) 3. 
offer benefits, such as the reduction of penalties and even full immunity, to offenders who cooperate with investigations in the prosecution of crimes committed by criminal organizations. ${ }^{544}$ The United Nations Convention against Corruption, signed in 2003 in Mérida, included a similar recommendation regarding the investigation of offenses related to public sector corruption..$^{545}$

This advocacy effort relies heavily on the results achieved with the use of cooperating defendants. Leniency policies create incentives for members of criminal organizations to come forward, denounce their co-conspirators and present relevant material. These mechanisms allow public authorities to obtain information and evidence from an internal source of the criminal organization, reducing the costs of investigations and accelerating their pace. The introduction of these policies in a jurisdiction is often followed by a boom in the number of investigations opened, convictions achieved and penalties imposed. ${ }^{546}$ Given these tangible effects, leniency policies are emphatically defended by authorities responsible for their implementation as essential tools for guaranteeing an effective prosecution system, particularly in situations where the obstacles to robust evidence collection are high and the damage caused by the investigated conduct is significant. ${ }^{547}$ The tangible results achieved with the use of cooperating defendants become a source of institutional reputation and are used to promote the legal innovations brought by the introduction of leniency policies. ${ }^{548}$

544 UNODC, 'United Nations Convention against Transnational Organized Crime and Protocols Thereto'. art. 26.

545 United Nations Convention against Corruption 2004. art. 37.

546 Regarding the investigate boom brought by leniency policies in the American and European anti-cartel enforcement, see Marvão and Spagnolo (n 32). According to the authors, "A yearly analysis of leniency applications in the European Union and the United States clearly shows that the number of cartels reported under a leniency policy and the number of individual leniency applications have both increased dramatically in recent years" (ibid., 59). Describing the enormous growth of the Mafia-related investigations after the expansion of the use of cooperating defendants in the Italian experience, see Musco ( $\mathrm{n}$ 346) 35-36. For a description of the Brazilian experience in the investigation of corruption networks, see item II.4.

547 As occurs in the prosecution of corruption networks and cartels. On the subject, see II.3.

548 Examining the effects prompted by the 1993 revision of the U.S. Department of Justice's Corporate Leniency Policy, William Kovakic notes that: "The DOJ placed a large and risky wager on a bold policy innovation, and it paid off handsomely. Unimaginably large fines poured into the Treasury, and a long queue of foreign antitrust officials approached the Department to learn how to do it 
Over recent years a mounting body of literature has arisen to examine, test and question the effectiveness discourse disseminated by enforcement agencies. Particularly in the field of anti-cartel enforcement, where the traces of the 'leniency revolution' are very clear and a large data set is available, a wide range of research has investigated the use of cooperating defendants from different perspectives, going beyond the simple statistics regarding the increase in convictions and penalties. Econometric and empirical studies sought to give a more comprehensive understanding of the impact of leniency policies on general deterrence and on the incentives created both for wrongdoers and enforcement agencies. Albeit confirming the assumption that leniency policies can bring important positive results, these studies have also raised awareness of various side effects and limitations, painting a much more complex picture than that commonly portrayed by enforcement authorities.

Based on this recent literature, this section examines risks that are inherent to the structure of leniency policies. Leniency policies transfer part of the state's prosecution activities - especially those related to the collection of information and evidence - from public authorities to cooperating defendants. ${ }^{549}$ Leniency policies create a scenario in which an accused is both the subject and the object of state prosecution. ${ }^{550}$ As the subject of the prosecution, the collaborator collects and supplies law enforcement authorities with elements that will be useful in holding other offenders liable. The material provided by the cooperator relates to wrongful conduct committed by third parties, which are not identical to the crimes the cooperator has committed. ${ }^{551}$

By transferring part of the investigation activities to private agents (the offenders), leniency policies engender a form of principal-agent relationship. ${ }^{552}$ In such relationships, a party - called the "agent" - performs, in

themselves. In light of these results, one can understand why the DOJ and other competition agencies might resist suggestions that leniency regimes require a serious rethink or major adjustments". See Kovacic, "A Case for Capping the Dosage: Leniency and Competition Authority Governance' (n 378) 192.

549 Centonze (n 1) 44. For a comprehensive view of the "privatization" movement in the German investigative procedure, see Stoffer (n 23). For a critical view, especially in regard to the prosecution of economic crimes, see Hefendehl, 'Außerstrafrechtliche Und Strafrechtliche Instrumentarien Zur Eindämmung Der Wirtschaftskriminalität' (n 12) 846.

550 Jeßberger, Kooperation Und Strafzumessung: Der Kronzeuge Im Deutschen Und Amerikanischen Strafrecht (n 1) 26.

551 Mehrens (n 11) 29.

552 Centonze (n 1) 44-45. 
exchange for some kind of payment, activities to obtain a result in favor of another party - called the "principal". ${ }^{553}$ As the principal has limited information about the agent's activities and difficulties in monitoring his efforts, multiple opportunities arise for the agent to obtain excessive benefits, thus harming the principal. ${ }^{554}$ In leniency policies, the principal-agent relationship is clear: offenders agree, in exchange for certain benefits, to cooperate with law enforcement authorities, which have serious limitations in assessing the offenders' level of effort. Two main concerns arise in this scenario.

Firstly, there is a structural asymmetry of information that puts law enforcement authorities at a disadvantage and benefits the offenders, since they have detailed knowledge about the illegal activities that they may or may not choose to share with authorities. Therefore, as in other fiduciary relationships, the cooperative endeavor devised by leniency policies is subject to risks of falsification, embellishment and omission of the information held by the cooperators. ${ }^{555}$

The second concern is that law enforcement authorities and cooperating offenders clearly pursue, through leniency policies, different goals. ${ }^{556}$ While public authorities seek to maximize the effectiveness of prosecution, it is by no means to be expected that the cooperating offender genuinely shares this goal. Cooperating offenders are motivated by utilitarian reasons ${ }^{557}$ and genuine repentance is not an essential element for resorting to leniency policies. ${ }^{558}$ Once they decide to leave the criminal organization and cooperate with the investigations, offenders will act strategically to maximize their leniency benefits and to minimize the agreement's collateral damages. 559

Given the different objectives and informational asymmetry between law enforcement authorities and offenders, cooperating defendants may

553 Steven Shavell, 'Risk Sharing and Incentives in the Principal and Agent Relationship' (1979) 10 The Bell Journal of Economics 55, 55.

554 Robert Cooter and Bradley J Freedman, 'The Fiduciary Relationship: Its Economic Character and Legal Consequences' (1991) 66 New York University Law Review , 1046-1047.

555 Shapiro (n 366) 350-351.

556 Centonze (n 1) 44-45.

557 Colombo (n 383) 511.

558 Malek, 'Die Neue Kronzeugenregelung Und Ihre Auswirkungen Auf Die Praxis Der Strafverteidigung' (n 481) 201.

559 For a detailed analysis of this issue, see Harding, Beaton-Wells and Edwards (n 484) $357-365$. 
adopt several behaviors that can seriously undermine the legitimate goals pursued by leniency policies. Leniency policies aim to increase the effectiveness of law enforcement against specific forms of criminality, either by detecting criminal activities and gathering relevant material for the prosecution of co-conspirators, or by enhancing distrust and instability among criminal organizations. Such goals are achieved by an incentive system designed to motivate agents involved in collective illegal transactions to report their accomplices, in exchange for immunity or penalty reduction. However, as with any incentive system, leniency policies may lead to serious counterproductive outcomes when not correctly designed. 560 The following items examine in more detail some of the risks associated with the introduction of these policies.

\section{a. Misrepresentation of facts: under- and over-cooperation}

An initial risk arises from the difficulty faced by law enforcement authorities in confirming the information presented by the offender. ${ }^{561}$ The offender invariably has more knowledge about the investigated facts than the public authorities. Although this informational asymmetry is the central reason for the use of leniency policies, it also limits the ability of public authorities to determine the quality of the information provided by the offender and to verify their degree of commitment to the investigations. ${ }^{562}$ Offenders may misuse the informational asymmetry to select the evidence shared so as to reduce the negative consequences of the confessed crimes in other fields, ${ }^{563}$ such as civil damages actions. Selective cooperation can also be used to target investigations against some offenders while protecting

560 Buccirossi and Spagnolo (n 29) 1296.

561 The lack of credibility of the narrative presented by the cooperator and the difficulty in determining its accuracy is a recurrent subject in the German literature regarding the use of leniency policies. See Hassemer (n 11) 552; Jeßberger, Kooperation Und Strafzumessung: Der Kronzeuge Im Deutschen Und Amerikanischen Strafrecht (n 1) 127-130; Jung (n 442) 40-41.

562 Florian Jeßberger speaks of a "paradox" in the use leniency policies: on one side, the proximity of the cooperating defendant to the illegal practices is what guarantees access to vital information and evidence; on the other, this proximity engenders various possibilities for the manipulation and distortion in the reconstruction of facts. See Jeßberger, 'Nulla Poena Quamvis in Culpa: Ammerkungen Zur Kronzeugenregelung in $\$ 46 S t G B '$ (n 2) 1164.

563 Kloub (n 145) 7. 
others. ${ }^{564}$ At the same time, given the great benefits offered by leniency policies, there is also a risk that the cooperator will present elements of little value for the investigation ${ }^{565}$ or even offer false reports. ${ }^{566}$

As occurs in other principal-agent situations, the relationship between law enforcement authorities and cooperating offenders is highly unbalanced, with the offender holding a high degree of informational control over the facts that the authorities seek to discover or understand. ${ }^{567}$ Given that criminal organizations typically employ sophisticated methods to destroy and conceal evidence, the intelligence held by the offender is normally not accessible to law enforcement authorities through other methods. This creates a scenario of strong opportunities for deception, in which the offenders have incentives to exploit - consciously or unconsciously - the ignorance of the authority in order to maximize the leniency benefits.

In addition to deciding whether or not to cooperate, offenders also have to choose what information and evidence they will share with the authorities. ${ }^{568}$ Therefore, although leniency policies always require cooperation with the investigations, the degree and quality of the assistance provided by offenders may vary widely. Am erroneous finding of facts can arise either from a situation of under-cooperation - in which there is a partial omission of the information and evidence held by the offender - or of over-cooperation - in which the reported facts are exaggerated. Leniency policies create, in certain circumstances, incentives for excessive reporting and, in others, incentives for incomplete reporting. ${ }^{569}$

Under-cooperation can clearly minimize the costs for the offender. Given the exposure to other forms of liability, including civil actions, the offender has no interest in revealing the illegal activities, or their participa-

564 Dell'Osso (n 373) 205.

565 In this regard, Forrester and Berghe point out that the incentive system designed by leniency policies encourage collaborators to include, in their reports, the largest possible number of elements, though marginal, in order to maximize the benefits obtained. See Ian S Forrester and Pascal Berghe, 'Leniency: The Poisoned Chalice or the Pot at the End of the Rainbow?' in Caron Beaton-Wells and Christopher Tran (eds), Anti-Cartel Enforcement in a Contemporary Age: Leniency Policies (Hart Publishing 2015) 247-248.

566 Centonze (n 1) 58.

567 Shapiro (n 366) 348.

568 Harding, Beaton-Wells and Edwards (n 484) 358-359.

569 For the incentives of under-cooperation, see: Jeßberger, 'Nulla Poena Quamvis in Culpa: Ammerkungen Zur Kronzeugenregelung in $\$ 46 S t G B$ ' (n 2) 1164; Spagnolo (n 30) 295. For the incentives of over-cooperation, see: Forrester and Berghe (n 566); and Centonze (n 1) 58. 
tion in them, completely. ${ }^{570}$ In this scenario, it is attractive for the offender to provide only partial and selective information, albeit sufficient to secure the desired benefit, while destroying or concealing evidences that they do not wish to share. ${ }^{571}$ Given that authorities do not have prior knowledge of the scope and reach of the reported offense, the cooperator may act strategically within the framework of the leniency policy, withholding as much information as possible so as to obtain maximum benefits with minimal possible negative outcomes. ${ }^{572}$

An inaccurate reconstitution of the facts can also result from a situation of over-collaboration. Given the incentive structure created by leniency policies, there is a constant risk of obtaining irrelevant information or even untrue reports. ${ }^{573}$ In order to maximize the benefits obtained through leniency policies, cooperating defendants are prone to exaggerate their account of the reported facts, including ancillary aspects of the conduct and painting grey situations in black tones. ${ }^{574}$ It is common that leniency policies establish a direct relation between the breadth of the cooperation provided by the defendant and the benefits granted to him or her. ${ }^{575}$ Therefore, once the offender decides to apply for leniency benefits, there are incentives to convince authorities to overestimate the significance of the offered cooperation, leading to exaggerated or distorted reports..$^{576}$

570 Wils, 'Leniency in Antitrust Enforcement: Theory and Practice' (n 378$) 216$.

571 Spagnolo (n 30) 295.

572 Jindrich Kloub (n 145) 7.

573 Centonze (n 1) 247-248.

574 As noted by Forrester and Berghe: "leniency applicants have an interest in embellishing their confessions to include marginal conduct. 'When in doubt, confess' could be the motto of the leniency policy". See Forrester and Berghe (n 566) 172.

575 This is the case of the rewarded collaboration regulation introduced by the 2013 Organized Crime Act, which designed a system of "quid-pro-quo" negotiations. The Brazilian antitrust leniency program, on the other hand, engendered a "winner-takes-it-all" leniency system. On the subject, see item I.3.b. For a comparison between the rationality of the two systems, see Feess and Walzl (n 153).

576 The European Court of Human Rights has expressed concern with this issue: "The Court is conscious of the fact that the cooperation of pentiti is a very important weapon in the Italian authorities' fight against the Mafia. However, the use of statements by pentiti does give rise to difficult problems as, by their very nature, such statements are open to manipulation and may be made purely in order to obtain the advantages which Italian law affords to pentiti, or for personal revenge". See the ruling: Labita v Italy App no 26772/95 (ECtHR, 6 April 2000). 
This scenario is worse in corporate environments, where defendants are normally under significant pressure to wind up the investigation quickly. ${ }^{577}$ Unlike what occurs in purely criminal organizations, the opening of formal proceedings creates a series of collateral effects upon agents active in legitimate industries, exposing internal vulnerabilities and damaging reputations. ${ }^{578}$ In some cases, the choice between quick resolution through a cooperation agreement or an indefinite continuation of the proceedings may be the difference between bankruptcy and corporate survival. ${ }^{579} \mathrm{Un}$ der these circumstances, defendants may feel pressured by the corporate environment to acknowledge wrongdoing and cooperate with law enforcement authorities even in the absence of a clear breach of law, misrepresenting facts just to put a quick end to the investigation. ${ }^{580}$

b. The dark side of leniency: amnesty effect, recidivism and the need for limits

Another intrinsic side effect of leniency policies relates to their negative impact on the severity of penalties and, consequently, on the deterrent effect of an enforcement system. ${ }^{581}$ By granting penalty reductions and even full immunity, leniency policies reduce the negative consequences associated with wrongdoing, ${ }^{582}$ diminishing the incentives for complying with the law. If the benefits granted for cooperating offenders are excessive, the leniency system may end up stimulating the commitment of offenses rather

577 Neira Pena (n 375) 204-205.

578 Benjamin M Greenblum, 'What Happens to a Prosecution Deferred? Judicial Oversight of Corporate Deferred Prosecution Agreements' (2005) 105 Columbia Law Review 1863, 1884-1885.

579 Dell'Osso (n 373) 205.

580 Peter Reily compares this situation with the "innocence problem", a term traditionally used to refer to the false confessions engendered by the U.S. system of plea bargaining. See Peter R Reilly, 'Justice Deferred Is Justice Denied: We Must End Our Failed Experiment in Deferring Corporate Criminal Prosecutions' (2015) 2015 Brigham Young University Law Review 307, 350. On the "innocence problem", see Oren Bar-Gill and Oren Gazal Ayal, 'Plea Bargains Only for the Guilty' (2006) XLIX Journal of Law and Economics 353; and F Andrew Hessick III and Reshma M Saujani, 'Plea Bargaining and Convicting the Innocent: The Role of the Prosecutor, the Defense Counsel, and the Judge' (2002) 16 Brigham Young University Journal of Public Law 189.

581 Wils, 'Leniency in Antitrust Enforcement: Theory and Practice' (n 378) 277.

582 Motta and Polo (n 29) 349. 
than discouraging it. Leniency policies that are too generous provide an "easy way out" for offenders, ${ }^{583}$ encouraging illicit practices and leading to an outcome that is the opposite of that originally intended.

The reduction of penalties and the granting of immunity affect the proportionality that should exist between the practice of a wrongdoing and the sanction attached to it. ${ }^{584} \mathrm{~A}$ decrease in the expected sanctions creates incentives for the commitment of crimes, in what can be seen as a "dark side of leniency policies". 585 This collateral consequence produces an "amnesty effect", 586 increasing the returns derived from criminal behavior. Besides reducing deterrence, the granting of disproportionate benefits to cooperating defendants impacts the enforcement system negatively by increasing the costs of investigations. ${ }^{587}$

The risks arising from the 'amnesty effect', far from being only a theoretical question, manifest in a very concrete manner on the subject of recidivism. Repeat offenders are normally understood as a particular dangerous type of wrongdoer and it is common that sentencing guidelines stipulate harsher penalties for recidivists. However, leniency policies, when not properly designed, may end up stimulating recidivism, since the leniency applicant will commit a serious crime and - through the obtainment of full or partial immunity - retain the illegal profits earned from the wrongdoing. This scenario can create incentives for agents to enter into a recurrent game of 'commit a wrongdoing, apply for leniency', as some real-life situations indicate. 588

Repeated leniency applicants raise the question as to whether the leniency policy is discouraging the practice of wrongdoings or, on the contrary, spurring the commitment of illegal conduct. Given the 'amnesty effect', leniency policies have an ambiguous influence on the incentives for agents to adopt an illicit behavior: while they enhance the chance of detection of

583 Marvão and Spagnolo (n 32).

584 Musco (n 346) 116.

585 Acconcia and others (n 537) 43.

586 Harrington Jr. (n 29) 217.

587 Catarina Marvão, 'The EU Leniency Programme and Recidivism' (2016) 48 Review of Industrial Organization 1, 4.

588 On the field of anti-cartel enforcement, Brent Fisse asserts that "it is possible for corporations to play the game of 'enter into cartel, get immunity' on more than one occasion" and cite examples of recidivists that profited from the European Commission leniency program. See Brent Fissé, 'Reconditioning Corporate Leniency: The Possibility of Making Compliance Programmes a Condition of Immunity' in Caron Beaton-Wells and Christopher Tran (eds), Anti-Cartel Enforcement in a Contemporary Age : Leniency Religion (Hart Publishing 2015) 186. 
illicit conduct and increase the instability inherent to criminal organizations, they also boost the gains that may be obtained through the commitment of offenses. A large record of recidivists applying successfully to a leniency program raises concerns regarding its effectiveness and its overall impact on general deterrence. It may indicate that agents are learning to use (or abuse) the leniency rules to promote their own interests, reinforce criminal strategies and maximize illegal profits. ${ }^{589}$ Furthermore, it puts in doubt the fairness of the policy and affects its social credibility. ${ }^{590}$ Various studies report a worrisome pattern of recidivism amongst leniency beneficiaries and confirm the importance of this issue for a correct assessment of the effects of a leniency policy. ${ }^{591}$

In view of the adverse consequences resulting from the 'amnesty effect', the definition of strict limits for awarding preferential treatment to cooperating defendants is an important feature of a solid leniency policy. ${ }^{592}$ While generating incentives for wrongdoers to abandon the criminal organization and denounce their co-conspirators, leniency policies also must rigidly define the scope for the granting of benefits to confessed criminals. ${ }^{593}$ In order to guarantee that the positive impact brought by a lenien-

589 Marvão (n 588) 25.

590 Wouter PJ Wils, 'Recidivism in EU Antitrust Enforcement: A Legal and Economic Analysis' (2012) 35 World Competition 5.

591 According to Christopher Harding, Caron Beaton-Wells And Jennifer Edwards: "A brief survey of European Commission proceedings against cartels over the past 30 years reveals an interesting profile of corporate repeat players as defendants and successful leniency applicants". See Harding, Beaton-Wells and Edwards ( $\mathrm{n} 484$ ) 256. For a detailed analysis of the subject on the European system of anti-cartel enforcement, see Marvão (n 588) 25.

592 Multiple authors point in this direction. William Kovacic speaks of "capping the dosage" of leniency policies. See Kovacic, 'A Case for Capping the Dosage: Leniency and Competition Authority Governance' (n 378). Catarina Marvão asserts that leniency policies "may also have pro-collusive effects, which are reinforced by the fact that the cartels that are reported by a given firm are often in a single market. In summary, it appears clear that the guidelines should be more explicit and less generous, especially with regard to how repeat offenders are treated”. See Marvão (n 588) 25.

593 On the field of anti-cartel enforcement, Giancarlo Spagnolo asserts that "a welldesigned and implemented leniency program is one that makes the incentives of an individual (potential or real) cartel member as conflicting as possible with the interest of the cartel taken together. This means that a well-designed program must maximize incentives to betray the cartel by reporting important information to the Antitrust Authority, while at the same time limiting as much as possible the reduction in fines imposed on the whole cartel”. See Spagnolo ( $\mathrm{n}$ 30) 293. 
cy policy surpasses the associated negative effects, it is necessary that the award of advantages stays limited to the minimum necessary, avoiding inappropriate reduction of penalties. ${ }^{594}$

The need to balance the establishment of incentives for cooperation with limits on the granting of benefits gives rise to several constraints on the design of leniency policies. A recurrent restriction that appears in this context relates to the number of accused that can become cooperating defendants and gain privileged treatment in the investigation of a given offense. In the field of anti-cartel enforcement, it is common that leniency policies limit the possibility of granting differentiated treatment to one successful applicant per investigation. ${ }^{595}$ This "winner-takes-it-all" model aims to trigger a race between co-conspirators to become the first agent to blow the whistle, maximizing the distrust and enhancing the instability within a criminal organization. ${ }^{596}$ Furthermore, it restricts the amount of benefits granted overall to the participants of the illegal scheme and ensures that all other accountable agents receive the stipulated penalties in their entirety. ${ }^{597}$

Another frequent restriction concerns the discrimination in leniency regulations towards agents that have instigated or acted as a leader in the commitment of the offense. ${ }^{598}$ Several leniency policies prohibit ringleaders from receiving any differentiated treatment in exchange for cooperation, while others set limits to the benefits that can be awarded in these sit-

594 According to Wils: "It is thus crucial to design and apply leniency policies in such a way that this negative effect is outweighed by the positive effects discussed above, and that no more leniency is granted than strictly necessary to obtain these positive effects". See Wils (n 378).

595 As occurs in the Brazilian and American antitrust leniency programs. See Martinez (n 8).

596 According to Hammond: "This 'winner-take-all' approach sets up a race, and this dynamic leads to tension and mistrust among the cartel members". See Hammond, 'Detecting and Deterring Cartel Activity through an Effective Leniency Program' (n 455) 5.

597 On this issue, see: Spagnolo (n 30) 293.

598 There is much discussion on economic literature regarding the effects of exclusion or discrimination of ringleaders in leniency policies. See J Herre and Alexander Rasch, The Deterrence Effect of Excluding Ringleaders from Leniency Programs (University of Cologne 2009) 1; Michael Hesch, 'The Effects of Ringleader Discrimination on Cartel Stability and Deterrence - Experimental Insights' (2012) 3 Journal of Advanced Research in Law and Economics 9; Stephen Davies and Oindrila De, 'Ringleaders in Larger Number Asymmetric Cartels' (2013) 123 Economic Journal 524. 
uations. ${ }^{599}$ Such restrictions are normally justified by the concern that granting immunity or penalty reductions to ringleaders may end up stimulating the formation of cartels and criminal organizations and allowing the most dangerous agents to remain unpunished. ${ }^{600}$ The discrimination of ringleaders in leniency regulations theoretically increases deterrence through the reduction of the incentives for agents to instigate unlawful collusions and other wrongdoings. ${ }^{601}$

c. Distortion of incentives for enforcement authorities: leniency overreliance, statistical boost and the overheated market for cooperation

A core argument for the introduction of leniency policies is their impact on the incentives faced by participants of criminal organizations. A recurrent point stressed by enforcement authorities is that leniency policies create a prisoner's dilemma for offenders, setting up an incentive system that stimulates betrayals in the criminal organization and erodes the relationships of trust among co-conspirators. ${ }^{602}$ According to this view, leniency policies turn the confession of wrongdoings and the adoption of cooperative behavior into the dominant strategy in the game played by co-conspirators and, consequently, engender a permanent factor of destabilization of criminal organizations and of deterrence from their illegal practices. ${ }^{603}$

From another perspective, several authors point out that the use of leniency policies, besides affecting the incentives for defendants, also has a

599 Aubert, Rey and Kovacic (n 29) 1250: "In practice, leniency programs often refuse amnesty to ring-leaders".

600 As noted by: Leslie ( $\mathrm{n}$ 487) 480-481. The author, however, criticizes the restriction.

601 According to Bigoni, Fridolfsson, Le Coq and Spagnolo, these rules may have a positive deterrent effect "if firms wait for other firms to take the initiative of forming the cartel to keep the right to obtain leniency". On the other hand, they may have the opposite effect "because ringleaders become more trustworthy for other cartel members reducing their incentives to rush to report”. See Bigoni and others (n 138) 386.

602 On the breach of trust in corruption networks caused by leniency policies, see Lejeune (n 12) 88-89. For an association of leniency policies with the prisoner's dilemma, see Buccirossi and Spagnolo (n 29). 1282. Criticizing as naïve the traditional economic approach to the rationale of corporate wrongdoers, Ana Frazão, 'Corrupção e Compliance' in Claudio; Lamachia and Carolina Petrarcha (eds), Compliance: essência e efetividade (OAB 2018) 196-197.

603 For a strong defense of this position, see Leslie (n 487) 465-475 and 488. 
decisive impact on the behavior and the strategies of law enforcement agencies. The introduction of a program that awards benefits for cooperating defendants is a game changer not only for the accused, but also for the public authorities responsible for the investigation and prosecution of serious crimes. ${ }^{604}$ Leniency policies change - and may distort - the actions, priorities, allocation of resources and decision-making process of enforcement agencies. ${ }^{605}$

A central cause of this distortion stems from the fact that leniency policies significantly reduce the costs incurred by public authorities when investigating organized forms of criminality, since they transfer a relevant part of the task of fact-finding in a criminal inquiry to cooperating defendants. ${ }^{606}$ Leniency policies assign accused an active role within the apparatus of state prosecution: instead of remaining in the traditional defensive position, defendants become active agents in relation to wrongdoings committed by other individuals. ${ }^{607}$ In this new role as a "branch-office" of enforcement agencies, defendants collect evidence and information, screen relevant documents and perform other duties in the prosecution of third parties. ${ }^{608}$

This structure of leniency policies, which resembles the model of other public-private partnerships developed between public organs and private agents ${ }^{609}$ makes their use highly attractive to enforcement. ${ }^{610}$ This is particularly true in the investigation of wrongdoings - such as corruption networks and business cartels - that normally do not leave any visible damages and are committed through the ordinary routines of legitimate organizations. ${ }^{611}$ The correct determination of facts regarding these conducts

604 As noted Evgenia Motchenkova in the field of anti-cartel enforcement, "It is intuitively clear that a legally sanctioned opportunity for costless self-reporting changes the nature of the game played between the antitrust authority and the group of firms". See Evgenia Motchenkova, 'Effects of Leniency Programs on Cartel Stability' (2004) Discussion Paper 2004-98 Center for Economic Research Tilburg University, 2.

605 For an interesting analysis of this issue, see Kovacic, 'A Case for Capping the Dosage: Leniency and Competition Authority Governance' (n 378).

606 Centonze (n 1) 44-45.

607 Jeßberger (n 1) 26.

608 See Harry First, 'Branch Office of the Prosecutor: The New Role of the Corporation in Business Crime Prosecutions' (2010) 89 North Carolina Law Review 23, 97.

609 For a more thorough analysis of this issue, see item V.3.c.

610 See Stephan and Nikpay (n 527) 211.

611 See items II.3.a e II.3.b. 
faces several constraints due to inherent difficulties in the effective gathering of evidence, ${ }^{612}$ which makes the investigation costs markedly higher when compared to other types of crimes. ${ }^{613}$ In this context, the boundaries between serious crimes and regular conducts are very fine, and the use of traditional investigative mechanisms - such as search and seizure procedures and wiretapping - are often of an inconclusive nature.

Assistance provided by an internal source reduces the obstacles and uncertainties faced by enforcement authorities in the prosecution of organized forms of white-collar criminality, providing a fast and apparently reliable path to hold powerful individuals accountable for serious crimes. ${ }^{614}$ The minimization of investigative costs and the fast results brought about by cooperation with defendants encourage the deployment of leniency policies in place of other investigative tools and lead authorities to prioritize investigations that rely on cooperators.

Given the incentives for enforcement authorities, the rapid expansion of leniency policies after their introduction is a phenomenon noticeable in the experience of multiple countries and in different fields of enforcement. ${ }^{615}$ Over-reliance on leniency policies may generate several side effects on an enforcement system, affecting the use of traditional investigative mechanisms and reducing the potential for ex officio detection of wrongdoings. ${ }^{616}$ In the long run, it can also undermine the credibility of the investigative capacity of enforcement agencies, seen as unduly dependent on the assistance of former criminals. ${ }^{617}$

612 As noted by several authors. See Greco and Leite (n 17) 290; Lindemann (n 17); Nagel (n 341) 33.

613 See Martín (n 23) 70.

614 Regarding the recent Brazilian experience with the use of the rewarded collaboration regulation to investigate "macro-deliquency", see item II.4.

615 For a good description of the recent "leniency revolution" in anti-cartel enforcement, see Spagnolo (n 30) 261-68. Analysing the Italian experience with of cooperating defendants in the investigation of mafia organizations, Enzo Musco holds that the use of this mechanism has grown "unprecedentedly to reach enormous, gigantic dimensions, unthinkable at the moment of the introduction of the legislation on cooperation". See Musco (n 346) 35.

616 On this subject, Caron Beaton-Wells asserts that "Over-reliance on leniency at the expense of investment in other detection tools undermines the perceived threat of detection, independent of such policies". See Beaton-Wells (n 448) 18. For a wide-ranging defense of the use of ex officio tools in the investigation of cartels, see Friederiszick and Maier-Rigaud (n 521).

617 In Italy, over-reliance on cooperating defendants is often indicated as one of the central factors to the loss of credibility in mafia-related investigations in the mid-1990s. See Paoli (n 512) 872. See also: Megan Dixon and Ethan Kate, 'Too 
Another risk associated with the over-reliance on cooperating defendants is the misplaced use of enforcement statistics - such as the number and amounts of imposed penalties, recovered financial sums and successful leniency applications - as a measure to assess the performance of public agencies. Enforcement agencies have strong incentives to actively advertise the results achieved by leniency policies, communicating these developments as proof of enhanced effectiveness in the prosecution of serious crimes. ${ }^{618}$ These statistics, however, are misleading as indicators of effectiveness, since they turn a blind eye to the overall number of wrongdoings and neglect the impact of the amnesty effect on the incentives for commitment of new violations. ${ }^{619}$ Because of this impact, the introduction of leniency policies can generate a boost in the statistics regarding convictions and fines imposed on wrongdoers and, at the same time, jeopardize the objective of increased deterrence. ${ }^{620}$ When improperly conceived, leniency programs - while reducing the costs of investigation, streamlining the activities of public authorities and generating visible results - may end up having a negative overall effect on an enforcement system. ${ }^{621}$

There are, therefore, several reasons to analyze the official discourse of enforcement agencies, which usually describes leniency policies as highly effective tools of deterrence, with a degree of skepticism. ${ }^{622}$ Law enforcement authorities not only lack incentives to acknowledge the shortcom-

Much of a Good Thing? Is Heavy Reliance on Leniency' (2014) 2014 CPI Antitrust Chronicle.

618 William Kovakic notes that "leniency can reinforce an unhealthy disposition to treat fines recovered and prison sentences imposed as the appropriate means for assessing agency effectiveness" and that "leniency applications can yield more cases and raise the level of fines or other sanctions the agency obtains. In particular, leniency can raise the financial recoveries that command attention in the business press". See Kovacic, 'A Case for Capping the Dosage: Leniency and Competition Authority Governance' (n 378) 193 and 194.

619 Marvão (n 588) 25.

620 On this point, William Kovakic observes that "an agency focused on maximising activity levels runs a risk of making compromises that increase the number of visible outcomes (for example, fines recovered), at the expense of future deterrence". See Kovacic, 'A Case for Capping the Dosage: Leniency and Competition Authority Governance' (n 378) 195.

621 Highlighting the need for strict limits in the granting of benefits to cooperating defendants, Spagnolo affirms that the goal of a leniency policy should be enhancing deterrence, and not "making the job of prosecutors easier". See Spagnolo (n 30) 293.

622 Nathan H Miller, 'Strategic Leniency and Cartel Enforcement' (2009) 99 American Economic Association 750, 751. 
ings and side effects of leniency policies, but are also prone to administer such mechanisms in a flexible and generous manner. ${ }^{623}$ Because the benefits of visible outcomes are promptly internalized by public agencies, while the long run costs of these mechanisms are inconspicuously externalized to society, the incentives for the development of an "overheated cooperation market" are very strong. ${ }^{.24}$ Contrary to the official discourse and ordinary assumptions, the introduction of a leniency policy may generate several successful cases of prosecution and, simultaneously, lead to an increase in the commimtment of crimes. ${ }^{625}$

d. Gaming the leniency system: repeated games, sophisticated agents and reverse exploitation

Leniency policies are usually defended on the basis that they expand the investigative capacity of law enforcement authorities and increase the efficiency of the state response to new types of criminal structure. ${ }^{626}$ Besides creating a new channel for the detection of wrongdoings and the collection of evidence, they are also expected to encourage defection and enhance distrust between co-conspirators within criminal organizations. ${ }^{627} \mathrm{~A}$ common assertion is that leniency policies create a prisoner's dilemma for co-conspirators, creating incentives for them to abandon the criminal organization and cooperate with public authorities. ${ }^{628}$

Although normally described as mechanisms that empower law enforcement authorities, leniency policies also provide new opportunities for offenders to adopt strategic behaviors and, through innovative methods, turn

623 Marvão and Spagnolo (n 32) 92.

624 Weinstein (n 3) 564-565. According to the author: "The current market for snitches cannot optimize the use of cooperation because these decision-makers internalize the benefits and externalize (and so largely ignore) the costs".

625 Joseph E Harrington and Myong Hun Chang, 'When Can We Expect a Corporate Leniency Program to Result in Fewer Cartels?' (2015) 58 Journal of Law and Economics 417, 419.

626 See item III.2.a. In German criminal law literature, see Hoyer (n 442); Jung (n 442); Buzari (n 12).

627 See item III.2.b. Highlighting the preventive effect of leniency policies on the formation of criminal organizations, see: Schlüchter (n 495) 68. Also: Lejeune (n 12) 87-88.

628 Leslie (n 487) 456-458. 
the possibility of cooperation into a device to maximize profits. ${ }^{629}$ The interactions between law enforcement authorities and criminal organizations are much more complex than a one-shot prisoner's dilemma, more closely resembling a scenario of "repeated games", ${ }^{630}$ where players constantly evolve by learning from past experiences ${ }^{631}$ and implement their strategy anticipating the reactions of opponents. 632

Leniency policies change the structure of the game played by law enforcement authorities and members of criminal organizations and all participants will adapt to the new circumstances, learning from past experiences and evolving to explore the possibilities created by this new environment. ${ }^{633}$ This is particularly true in the field of economic and corporate crimes, in which organizational resources allow for the commitment of highly complex and sophisticated criminal conduct. ${ }^{634}$ Given the high rewards that arise from illicit behavior and the resourcefulness of legitimate corporations, cartels and corruption networks are constantly developing new solutions for the challenges posed by law enforcement. ${ }^{635}$

629 Analyzing the antitrust leniency programs, Catarina Marvão notes that "it seems that firms are able to use it to their own benefit, in some unintended ways". See Marvão (n 588) 25.

630 Motta and Polo (n 29); Harrington Jr. (n 29).

631 The capacity of agentes to learn and adapt in scenarios of repeated games is recurrent theme in economic literature. See John H Nachbar, 'Prediction, Optimization, and Learning in Repeated Games' (1997) 65 Econometrica 275; Drew Fundenberg and Eric Maskin, 'American Economic Association Evolution and Cooperation in Noisy Repeated Games' (1990) 80 Source: The American Economic Review 274.

632 In this sense, Fudenberg and Maskin assert that "That strategic rivalry in a longterm relationship may differ from that of a one-shot game is by now quite a familiar idea. Repeated play allows players to respond to each other's actions, and so each player must consider the reactions of his opponents in making his decision. The fear of retaliation may thus lead to outcomes that otherwise would not occur". See Drew Fudenberg and Eric Maskin, 'The Folk Theorem in Repeated Games with Discounting or with Incomplete Information' (1986) 54 Econometrica 533, 533.

633 Kovaci, 'A Case for Capping the Dosage: Leniency and Competition Authority Governance' (n 378) 196-197.

634 See item II.3.b.

635 Examining the German experience, Britta Bannenberg asserts the sophistication, resourcefulness and adaptability of corruption networks. See Bannenberg (n 17) 108-114. On a similar note: Zambrano Leal (n 355) 30-33. On the field of anticartel enforcement, Wils observes that "successful cartels tend to be sophisticated organizations, capable of learning. It is thus safe to assume that cartel participants will try to adapt their organization to leniency policies, not only so as to 
Leniency policies amplify the role played within the apparatus of state prosecution by accused, who abandon a defensive stance to become active agents in the collection of information and evidence. ${ }^{636}$ The cooperating defendant takes over part of the state's prosecution tasks, becoming a key player in the process of fact-finding and establishment of criminal liability. ${ }^{637}$ For sophisticated agents, this new role may seem an empowering situation, one that creates new opportunities for the for the fulfillment of individualistic goals through the reverse exploitation of the leniency system. ${ }^{638}$

A much debated example in economic literature refers to the use of leniency policies as a strategic device to stabilize relationships within the criminal organization, strengthening the "internal discipline" through threats of retaliation against dissidents. ${ }^{639}$ Since co-conspirators cannot enforce the illegal arrangements through legitimate channels, leniency policies can be exploited to coerce the members of the organization to comply with the unlawful deals under the penalty of being reported. ${ }^{640}$ The triggering of leniency policies may be used as a credible threat to demand the fulfillment of illegal transactions that would otherwise be devoid of any enforcement mechanism. The possibility of denouncement to authorities provides an internal enforcement mechanism and may ultimately make illicit arrangements between offenders more stable. ${ }^{641}$

minimize the destabilising effect, but also, where possible, to exploit leniency policies to facilitate the creation and maintenance of cartels". See Wils (n 378) 230.

636 Jeßberger, Kooperation Und Strafzumessung: Der Kronzeuge Im Deutschen Und Amerikanischen Strafrecht (n 1) 26.

637 Centonze (n 1) 44.

638 Harding, Beaton-Wells and Edwards describe this situation as "'strategic' leniency, leniency 'gaming' or 'reverse exploitation'”. See Harding, Beaton-Wells and Edwards (n 484) 361.

639 On this issue, see: Buccirossi and Spagnolo (n 29) 1282-1283; Wils (n 378) 231.

640 Giancarlo Spagnolo notes that "in corrupt relationships where transactions are frequently repeated, moderate leniency programs can increase the parties' ability to punish deviations, thereby stabilizing the illegal arrangements by reducing gains from defecting. In practice, the information that wrongdoers have on each other plays the role of a "hostage" that is used as a credible threat to govern the illegal exchange and punish failures to comply with the agreement". See Spagnolo (n 30) 275.

641 Aubert, Rey and Kovacic (n 29) 1262-1263. 
Another risk is the possible use of leniency policies as strategic tools to harm competitors and obtain advantages in the struggle for markets. ${ }^{642}$ In a context of fierce competition in legitimate industries, the possibility of exposing other firms while evading sanctions establishes a clear opportunity for raising the costs of competitors and gaining ground in the market. An important concern arises from evidence indicating that a large part of the infringements reported by leniency applicants refers to illicit schemes that were already inoperative or on the verge of breaking up. ${ }^{643}$ Leniency policies create the possibility for wrongdoers to "tame the end-game" of a failed or dying illegal arrangement and, at the same time, harm their former co-conspirators and now rivals. ${ }^{644}$

\section{Conclusion: leniency revolution and leniency religion}

Leniency policies can constitute important tools in the investigation of corruption networks and cartels, offenses usually carried out through sophisticated and deceptive strategies and capable of causing high, diffuse losses while leaving no visible trace of damage and no tangible evidence of the illegal conduct. ${ }^{645}$ Due to the characteristics of these wrongdoings, state authorities face great obstacles in uncovering the crimes committed and, even in case of detection, encounter serious difficulties in the collection of evidence capable of determining the facts and establishing legal responsibilities. Leniency policies enable state authorities to obtain information and evidence of inestimable value for the development of an efficient prosecution system for corrupt practices and collusion schemes. Besides facilitating the detection of crimes and the gathering of evidence, leniency policies also have the important effect of enhancing the conflicts and instabilities in criminal organizations. The incentive system designed by lenien-

642 Ellis and Wilson note that "the introduction of leniency policy allows some Örms to gain a market advantage from self-reporting”. See Christopher J Ellis and Wesley W Wilson, 'What Doesn't Kill Us Makes Us Stronger: An Analysis of Corporate Leniency Policy' 1, 33.

643 For an analysis in this direction regarding the leniency program of the European Comission, see Stephan and Nikpay (n 527).

644 Andreas Stephan, 'An Empirical Assessment of the European Leniency Notice' (2008) 5 Journal of Competition Law and Economics 537, 559.

645 On the losses caused by these practices, see item II.3.c. On the problems of factual-finding and collection of evidence, see items II.3.a e II.3.b. 
cy policies creates a constant threat of defection and whistleblowing, eroding an essential element of criminal organizations: trust.

In the last decades, more and more jurisdictions have adopted leniency regulations in multiple fields of law enforcement, as a means of enhancing the capacity of public authorities to develop an efficient system of prosecution and reduce impunity amongst individuals responsible for serious offenses. In this context, the U.S. leniency practices have often set a remarkable standard followed by other countries, ${ }^{646}$ particularly in the realm of white-collar crime prosecution. According to some reports, the American example showed that the concept of leniency was "a wildly successful idea", ${ }^{647}$ and became the source of "tremendous global emulation" ${ }^{648}$ The experiences of different countries indicate that the introduction of leniency policies is commonly followed by a sharp increase in the number of important investigations and compelling convictions. In view of these visible results and the proliferation of leniency policies worldwide, several authors have spoken of a "leniency revolution". ${ }^{649}$

Despite this palpable and well publicized success, a growing body of literature has emerged recently to question the effectiveness, the working mechanisms and even the theoretical assumptions associated with leniency policies. Over the last years, different studies have thoroughly analyzed, tested and shown the risks arising from the employment of leniency policies. A fundamental point of concern is the overall impact of leniency policies on the deterrent effect of the enforcement system: because of the amnesty effect, leniency policies increase the profits obtained through illegal behavior and reduce the level of penalties, always containing a hardly noticeable "dark side". ${ }^{650}$ Another risk relates to the informational asymmetry that gives cooperating defendants significant control over the reported facts and limits the authorities' capacity to verify the accuracy and truthfulness of the narrative presented. 651 This asymmetry favors the adoption of opportunistic behavior, that can be carried out through strategies of under-cooperation or over-cooperation. The principal-agent structure of leniency policies also creates, in a scenario of repeated games and evolving actors, possibilities for reverse exploitation, that may even lead to the rein-

646 Malek (n 470) 566.

647 O'Brien (n 31) 15.

648 Kovacic, 'A Case for Capping the Dosage: Leniency and Competition Authority Governance' (n 378).

649 Spagnolo (n 30) 259.

650 Acconcia and others (n 537). See item III.3.b.

651 See item III.3.a. 
forcement of the illicit conduct. ${ }^{652}$ All in all, a robust body of literature indicates that the effects of the introduction of leniency policies in an enforcement system are far from being unequivocally positive. On the contrary, when inadequately designed and implemented, these policies may generate significant collateral damage and lead to counterproductive results.

A critical point of analysis is the way leniency policies change the practices and strategies of law enforcement authorities. ${ }^{653}$ These mechanisms enable the collection of information and evidence at a much lower cost than traditional investigative measures and are highly attractive when compared to other alternatives. Through leniency policies, private agents the cooperating defendants - perform a series of investigative acts on behalf of enforcement authorities, gathering evidence, screening the relevant material and organizing different elements into a coherent narrative. Furthermore, leniency policies generate faster outcomes and more certain results than autonomous investigations. Law enforcement authorities have, therefore, strong incentives to rely on cooperating defendants, even if this happens at the expense of granting generous benefits and, consequently, dramatically lowering the overall level of penalties.

Viewed in this light, the assessment of the impacts of a leniency policy on an enforcement system proves to be a much more complicated task than suggested by the usual approach of public authorities. Focused on reporting increased numbers of opened cases and imposed convictions, public authorities often underestimate and downplay the side effects and risks that arise from the establishment of cooperative relationships with confessed offenders. The emphasis on indicators such as successful prosecutions and applied sanctions overshadows the multiple costs of the employment of leniency policies. An upsurge of these statistics may have different meanings, one of which is simply a growth in the number of illegal activities. Simplistic appraisals grounded on the record of convictions and sanctions may suggest in the short-term a promising enforcement scenario, while generating several side effects that will be noticed only in the future. As Caron Y. Beaton-Wells has accurately observed, the perspective disseminated by enforcement authorities regarding leniency policies - marked by a inward-looking, narrow, isolated and uncritical approach - resemble a religion as much as a revolution. ${ }^{654}$

652 See item III.3.d.

653 See item III.3.c.

654 Beaton-Wells (n 33) 4 and 44. 


\section{Chapter IV - Consensual exchanges in German criminal procedure: the practice of negotiated judgments and the crown-witness regulation}

\section{Introduction}

The introduction of the rewarded collaboration regulation brought an important development to Brazilian law by designing a legitimate negotiation forum permitting defendants and law enforcement authorities to deal with each other and conclude written agreements on criminal proceedings. ${ }^{655}$ Since the enactment of the Organized Crime Act in 2013, the employment of collaboration agreements has swiftly expanded, particularly in the investigation of corporate crimes and corruption acts, with major impacts on Brazilian criminal law as well as on political life. ${ }^{656}$ The practice of collaboration agreements has developed bold consensual innovations that are not provided for in statutory text and diverge from the traditional logic of the Brazilian justice system. Over the years, legal practitioners have drawn on the rewarded collaboration regulation to develop a wide and flexible system of transactions, elaborating complex written arrangements and consensually resolving several matters within the remit of criminal justice. 657

This situation has engendered countless judicial disputes and raised difficult legal questions for courts and scholars. Unlike the U.S. experience, where transactions with defendants - including deals to cooperate against former co-conspirators - have long since become an entrenched practice due to the peculiarities of criminal prosecution, ${ }^{658}$ Brazilian law had until recently given little space for parties to transact over the course of criminal

655 See item I.2.b.

656 See items II.2 e II.4.

657 See items I.4.a and I.4.b.

658 On the particularities of the American criminal justice and its relationship with the development of cooperation between defendants and enforcement authorities, see Jaeger (n 3) 266-281; and Florian Jeßberger, Kooperation und Strafzumessung (n 1) 291-293. See also: Weinstein and Graham Hughes, 'Agreements for Cooperation in Criminal Cases’ (1992) 45 Vanderbilt Law Review 1. 
investigations. ${ }^{659}$ As in other countries of Continental traditional, standard pillars and concepts of criminal procedure have strictly limited the possibilities of consensual arrangements between accused and law enforcement authorities. In 1995, the Small Claims Act established mechanisms for the consensual resolution of criminal proceedings, but only in cases related to minor offenses. Apart from that, the complete adjudicative process remained the predominant model for the majority of cases in the Brazilian criminal justice system, in a context where negotiations between parties played a minor role.

Nevertheless, the consensual innovations brought by the practice of collaboration agreements received solid support from the Brazilian judiciary, especially from higher courts, and from part of domestic legal scholarship. This support was often grounded on the understanding that collaboration agreements are part of a new system of consensual or negotiated criminal justice, with different pillars and mechanisms than the traditional Brazilian criminal procedure. ${ }^{660}$ According to this view, the correct interpretation of collaboration agreements demanded the employment of theories and concepts normally associated with private contract law, such as the "res inter alios acta" principle, the protection of individual autonomy and good faith, the "venire contra factum proprium" doctrine and the rule of "pacta sunt servanda". ${ }^{661}$

This recent development in Brazilian law is influenced by foreign experiences, which are constantly used as a source of legitimacy for the many innovations that agreements between defendants and enforcement authorities brought to Brazilian criminal law. ${ }^{662}$ The reference to foreign experiences with consensual mechanisms in criminal investigations has often been used to validate the practice of collaboration agreements, justifying the detachment from principles of Brazilian law, such as strict legality and compulsory prosecution, for the sake of swifter and more efficient prosecu-

659 See item I.1 and I.2.

660 See item I.4.c.

661 On the application of the pacta sunt servanda rule to collaboration agreements and the issue of their binding effect, see item I.4.c.i. On the application of the "res inter alios acta" principle, see item I.4.c.ii.

662 As noted by different authors. See: Vasconcellos, Colaboração Premiada no Processo Penal (n 39) 22-23; Dino (n 426) 516. Observing, more broadly, the U.S. influence on the recent anti-corruption efforts in Brazil, see Ana Frazão and Ana Rafaela Medeiros, 'Desafios para a efetividade dos programas de compliance' in Ana Frazão and Ricardo Villas Bôas Cuevas (eds), Compliance: perspectivas e desafios dos programas de conformidade (Fórum 2018) 71-104. 
tion. ${ }^{663}$ Numerous voices defended the development of a comprehensive system of transactions in Brazilian criminal law based on the understanding that the rewarded collaboration regulation of the Organized Crime Act reflects a global trend towards a new paradigm of "consensual justice". ${ }^{664}$

The recent worldwide expansion of consensual mechanisms in criminal procedure is a well-documented phenomenon. Several countries of Continental tradition have implemented reforms in recent decades to increase the scope for inter-party negotiations in criminal justice, which for long time have been a distinctive feature of U.S. criminal procedure. ${ }^{665}$ In view of various social changes, European and Latin American countries have developed consensual forms of procedure that emulate, to a greater or lesser degree, the U.S. system of plea bargaining. ${ }^{666}$ Although assuming different forms according to the specificities of each legal system, consensual mechanisms basically operate by granting benefits to offenders who confess to a crime and consent to a summary process and conviction. ${ }^{667}$

This chapter examines the German experience with two legal mechanisms that provide a useful perspective for examining the problems and perplexities related to the recent development, through the practice of the rewarded collaboration regulation, of a broad negotiation forum between defendants and law enforcement authorities in the Brazilian justice system. As a country of Continental tradition, Germany provides an interesting example of the contradictions and difficulties associated with the introduction of consensual mechanisms in a context where criminal procedure is understood as an official investigation aimed at correctly establishing the

663 See items II.4 e II.5.

664 See Mendonça, 'Os possíveis benefícios da colaboração premiada: entre a legalidade e a autonomia da vontade' ( $n$ 36). See also the allegations of the Federal Public Prosecution Office in the following proceedings: STF, PET 7265 [2017] and STF, PET 5779 [2015]. In the jurisprudence of the Brazilian Federal Supreme Court, see STF, PET 7074 [2017] (Celso de Mello J).

665 Schünemann, 'Zur Kritik Des Amerikanischen Strafprozessmodells' (n 25) 569-571.

666 Langer (n 28) 38. On this issue, see: Thomas Weigend, Absprachen in ausländischen Strafverfahren: eine rechtsvergleichende Untersuchung zu konsensualen Elementen im Strafprozess (n 24); Thaman (n 28).

667 Mirjan Damaška, 'Symposium on Guilty Plea Part I: The Theoretical Background Negotiated Justice in International Criminal Courts' (2004) 2 Journal of International Criminal Justice 1018, 1019. For a critical assessment of this type of benefits, see: Luís Greco, Strafprozesstheorie Und Materielle Rechtskraft (Duncker \& Humblot 2015) 276-279. 
facts. ${ }^{668}$ In such a context, basic pillars of criminal justice - like the state's commitment to search for truth and the principle of compulsory prosecution - restricted for a long time the parties' capacity to dispose of criminal cases and resolve them through consensual exchanges. ${ }^{669}$

Item IV.2 describes the evolution of the practice of negotiated judgments ("Verständigung") in German criminal justice, ${ }^{670}$ which enabled defendants, prosecutors and courts to engage in consensual arrangements in

668 For the characterization of German criminal procedure as a system of official investigation, see: Langer (n 28) 20-26. Martin Heger observes that in German criminal procedure "the main goal is to enforce the state's responsibility to prosecute whenever a crime has been committed. In order to achieve this goal, both the court and the district attorney are obliged to determine the objective truth of a case, because the state's responsibility to prosecute and punish can only be enforced against a truly guilty party". See: Heger, 'Adversarial and inquisitorial elements in the criminal justice systems of European countries as a challenge for the Europeanization of the criminal procedure' (n 25) 198-205.

669 Thomas Weigend notes the incompatibility of the practice of consensual solutions with traditional principles of German criminal procedure, particularly in regard to the state's commitment to search for truth. See: Thomas Weigend, 'Abgesprochene Gerechtigkeit - Effizienz Durch Kooperation Im Strafverfahren?' (1990) 45 JuristenZeitung 774, 775-776. On the same note, Markus Dubber and Tatjana Hörnle assert that: "Within the framework of German criminal procedure, agreements are alien and problematic". See: Markus D Dubber and Tatjana Hörnle, Criminal Law: A Comparative Approach (Oxford University Press 2014) 169.

For a detailed discussion of the concepts of search for truth and consent in German criminal procedure, see: Greco, Strafprozesstheorie Und Materielle Rechtskraft (n 668) 169-187, 261-281. According to Greco, an adequate determination of the facts, that allows for the correct application of criminal law, must be understood as the "specific purpose" of German criminal procedure, even though that does not mean a flawless and unending investigation (187).

670 The practice of consensual arrangements in the German criminal justice described in the item IV.2 has gained different designations and labels over time: "Absprache", "Deal", and "Verständigung". This thesis will refer to these arrangements by the German term "Verständigung", which is used in the statute enacted by the German Parliament in 2009 to regulate the practice. In English, the thesis will use the term "negotiated judgments" to refer to these arrangements, as suggested by Thomas Weigend and Jenia Turner, see: Thomas Weigend and Jenia Iontcheva Turner, 'The constitutionality of negotiated criminal judgments in Germany' (2014) 15 German Law Journal 81. In English literature, it is common to refer to the German practice of negotiations in criminal justice as "plea bargaining”. See: Swenson (n 28); Samantha Cheesman, 'Comparative Perspectives on Plea Bargaining in Germany and the U.S.A' $<$ https://pu blishup.uni-potsdam.de/opus4-ubp/frontdoor/deliver/index/docId/7457/file/S11 3-151_aiup02.pdf> accessed 20 September 2019 ; Vanessa Carduck, 'Quo Vadis, 
criminal proceedings. This model of negotiation was developed informally in German courts in the 1970s, especially in cases involving white-collar crimes and drug trafficking. ${ }^{671}$ Since the rules of the German Criminal Procedure Code did not authorize these kind of negotiations, negotiated judgments in German criminal procedure stood for a long time as a praeter or contra legem practice. ${ }^{672}$ Only in 2009 did a legislative amendment add a specific section to the German Criminal Procedure Code ( $\$ 257$ c StPO), establishing statutory rules for the regular development of negotiated judgments in German criminal justice.

Item IV.3 analyzes the development in German law of the crown-witness regulation ("Kronzeugenregelung"), which allows offenders who cooperate with law enforcement authorities in the investigation of crimes committed by other individuals to obtain certain benefits. Introduced in 1982 through an amendment to the German Narcotics Law, this mechanism gained more relevance in 2009, when an amendment to the Criminal Code $(\$ 46 \mathrm{~b}$ StGB) devised a general framework for the concession of benefits to cooperating defendants.

The risks and pitfalls of comparative studies are well-known. Careless comparisons may reinforce false stereotypes or generate "legal counterfeits". ${ }^{673}$ Incautious assessments can overlook important aspects of an intricate phenomenon. On the other hand, the simplification of complex legal institutions can be productive, since it permits the recognition of the key aspects of multifaceted realities, releasing the analysis from the "tyranny of details" ${ }^{674}$ Comparative studies enable a critical understanding of develop-

German Criminal Justice System? The Future of Plea Bargaining in Germany' (2013) Warwick School of Law Research Paper 2013-17, 1 <https://papers.ssrn.c om/sol3/papers.cfm?abstract_id=2316828 $>$ accessed 20 September 2019; Alexander Schemmel, Christian Corell and Natalie Richter, 'Plea Bargaining in Criminal Proceedings: Changes to Criminal Defense Counsel Practice as a Result of the German Constitutional Court Verdict of 19 March 2013?' (2014) 15 German Law Journal 43. However, the use of the the term "plea bargaining" in the German context can be misleading, since there are fundamental differences between the U.S. model of negotiations and the German practice. For a good comparison between the two systems of negotiation, see: Brodowski (n 24).

671 Altenhain, Dietmeier and May (n 38) 20.

672 Heger and Pest (n 37) 446.

673 Luís Greco and Alaor Leite used the term "legal counterfeit" to criticize the use by the Brazilian Federal Supreme Court of the theory of dominion of the act ("Tatherrschaft"), as famously developed in German criminal law by Claus Roxin and other scholars. See: Greco and Leite (n 17).

674 Mirjan Damaska, 'Structures of Authority and Comparative Criminal Procedure' (1975) 84 The Yale Law Journal 480, 482. 
ments in domestic law, offering an external point of view from which important features become clearer. ${ }^{675}$ This analytical perspective may prove helpful as long as the object of study is strictly delimited. ${ }^{676}$

It is important, therefore, to frame the objectives and limits of this chapter. A detailed study of the two German legal institutions is obviously a task that is beyond the boundaries of the present thesis. In recent decades, the practice of negotiated judgments was one of the most widely discussed themes in German criminal law and has been subject of various comparative law studies. The German experience with the crown-witness regulation also entails a number of specificities and controversies which cannot be reproduced in this thesis.

More than a thorough study of both mechanisms, the description of their development seeks to establish the basis for two points discussed in section IV.4. Item IV.4.a contrasts the responses provided by the practice of negotiated judgments ("Verständigung") and the crown-witness regulation ("Kronzengenregelung") in face of the challenges posed by complex criminal investigations, particularly in the field of white-collar criminality, comparing the aspirations and functions of each legal mechanism within the German justice system. Item IV.4.b examines the tensions created by the expansion of consensual arrangements in the German justice system, their effects on the interests protected by criminal law, especially with regard to the state's commitment to an adequate process of fact-finding, and the difficulties in establishing boundaries for the development of negotiated judgments by legal practitioners. These two points will be relevant for the critical analysis of the Brazilian practice, which will be carried out in chapter $\mathrm{V}$.

\section{Negotiated judgments: practice and regulation}

The development of the practice of negotiated judgments ("Verständigung") within criminal justice has been a longstanding and controversial theme of debate in Germany. ${ }^{677}$ Countless books, articles and studies have been

675 Dubber and Hörnle (n 670) 4.

676 Damaska (n 675) 482.

677 According to Greco, negotiated judgments must represent "the most discussed subject in German criminal procedure scholarship over the last 20 years". See: Luis Greco, "Fortgeleiteter Schmerz" - Überlegungen zum Verhältnis von Prozessabsprache, Wahrheitsermittlung und Prozessstruktur' (n 26) 1-15. 
written on the theme since its emergence. ${ }^{678}$ Multiple decisions of German higher courts have also dealt with the topic over the last decades. ${ }^{679}$ The controversies regarding the practice of negotiated judgments in the German system of criminal justice have attracted international attention and prompted a large number of comparative analyses, in particular to the U.S. model of plea bargaining. ${ }^{680}$

The level of interest provoked by the subject is understandable. Germany has for a long time provided a remarkable example of Continental criminal justice, serving as common counterpoint to American criminal procedure. ${ }^{681}$ The traditional German model of official investigation, like other Continental jurisdictions, presented substantial differences when compared to the U.S. party-driven justice system, particularly regarding the roles of procedural participants in the process of fact-finding and their ca-

678 See: Winfried Hassemer, 'Pacta sunt servanda - auch im Strasprozess?' (1989) 11 Juristische Schulung 890, 890-895; Schunemann, 'Gutachten, Kongressvortrag, Aufsatz | Absprachen im strafverfahren - Grundlagen, Gegenstande und Grenzen' (n 38); Weigend, 'Abgesprochene Gerechtigkeit — Effizienz Durch Kooperation Im Strafverfahren?’ (n 670).; Karsten Altenhain, Frank Dietmeier and Markus May, Die Praxis Der Absprachen in Strafverfahren (Nomos Verlagsgesellschaft 2013) ; Mathias Jahn and Martin Müller, 'Das Gesetz zur Regelung der Verständigung im Strafverfahren - Legitimation und Reglementierung der Absprachenpraxis' (2009) 62 Neue juristische Wochenschrift 1; Heger and Pest (n 37). For studies published in English, see: Jachim Herrman, 'Bargaining justice a bargain for German criminal justice' (1991) 53 University of Pittsburgh Law Review 755; Swenson (n 28); Thomas Weigend, 'The Decay of the Inquisitorial Ideal: Plea Bargaining Invades German Criminal Procedure' in John Jackson and others (eds), Crime, Procedure and Evidence in a Comparative and International Context (Hart Publishing 2008).

679 See the following rulings of the German Federal Constitutional Court: BVerfG, Beschl. v. 27.1.1987 - 2 BvR 1133/86 = NJW 1987, 2662; and BVerfG, Urt. v. 19.3.2013 - 2 BvR 2628/10 u.a. = BVerfGE 133, 168. See also two important decisions of the German Federal Court of Justice: BGH, Urt. v. 28.8.1997 - 4 StR 240/97 = BGHSt 43, 195; and BGH, Beschl. v. 3.3.2005 - GSSt 1/04 = BGHSt 50, 40.

680 See, e.g. Weigend, Absprachen in ausländischen Strafverfahren: eine rechtsvergleichende Untersuchung zu konsensualen Elementen im Strafprozess (n 24); Peters, Urteilsabsprachen im Strafprozess: Die deutsche Regelung im Vergleich mit Entwicklungen in England \& Wales, Frankreich und Polen (Universitätsverlag Göttingen 2011); Brodowski (n 24). For literature in English, see Langer, From legal transplants to legal translations: the globalization of plea bargaining and the Americanization thesis in criminal procedure (n 28); Thaman (n 28).

681 See: John H Langbein, 'Land without Plea Bargaining: How the Germans Do It' (1979) 78 Michigan Law Review 204. Critically: Dubber (n 28). 
pacity to dispose of criminal cases. ${ }^{682}$ In this context, a striking contrast concerned the use of consensual exchanges to resolve criminal proceedings: while the American approach to criminal procedure as a dispute between prosecution and defense allowed for different types of transactions within criminal cases, the core values and basic principles of German criminal justice restricted the possibilities of inter-party negotiations ${ }^{683}$. Although a legislative reform in the early 1970s facilitated the use of consensual solutions in German criminal procedure, it restricted the applicability of the introduced negotiation mechanism to cases related to minor offenses. ${ }^{684}$ In this context, the distinguished comparative scholar John Langbein, in a famous article published in 1979, applauded the German legal system for avoiding "any form or analog of plea bargaining in its procedures for cases of serious crime" and used the German experience to harshly criticize the American dependence on plea bargaining. ${ }^{685}$

Against this background, the revelation in the early 1980s that the practice of informal and concealed negotiated judgments had, furtively and without any legislative authorization, spread in German criminal justice, particularly in investigations of white-collar crimes, caused great surprise and perplexity. ${ }^{686}$ This section provides a general overview of the impetuous and troubled evolution of consensual solutions in German criminal procedure. Item IV.2.a describes the conceptual pillars that hindered for a long period the development of consensual solutions in German criminal justice. Item IV.2.b examines the appearance of informal consensual solutions in German criminal practice in the final decades of the 20th century. Item IV.2.c analyzes the response from German higher courts to the devel-

682 Schünemann, 'Zur Kritik Des Amerikanischen Strafprozessmodells' (n 25) 558-562; Jaeger (n 3 ) 266-229; Florian Jeßberger, Kooperation und Strafzumessung: der Kronzenge im deutschen und amerikanischen Strafrecht (n 1) 159-163. About this theme, see item V.2.a.

683 Langer (n 28) 35-39.

684 The reform introduced section $₫ 153 \mathrm{a}$ in the German Code of Criminal Procedure, which established possibilities for prosecutors and defendants to resolve investigations of minor offenses through consensual arrangements. See: Janique Brüning, 'Die Einstellung Nach $\$ 153$ a StPO - Moderner Ablasshandel Oder Rettungsanker Der Justiz?' (2015) 12 Strafrecht - Jugendstrafrecht - Kriminalprävention in Wissenschaft und Praxis 125. In English: Dubber and Hörnle (n 670) 159-161.

685 Langbein (n 682) 205 and 224-225.

686 The first article that revealed and described the practice of negotiated judgments was published in 1982. See Detlef Deal, 'Aus Der Praxis. Der Strafprozessuale Vergleich' (1982) Strafverteidiger 545. 
opment of informal consensual solutions in the practice of criminal law. Item IV.2.d describes the legislative reform, approved in 2009, that sought to regulate the employment of consensual solutions in German criminal justice, through the introduction of section $\$ 257 \mathrm{c}$ in the German Code of Criminal Procedure ( $\$ 257 \mathrm{c}$ StPO). Item IV.2.e reports the 2013 decision of the German Constitutional Court on the constitutionality of the statutory rules that regulate consensual solutions in German criminal procedure.

a. Search for truth, compulsory prosecution and consent in the German tradition

The traditional basis of German criminal procedure provides little room for the procedural parties - prosecutors and defendants - to negotiate over outcomes of criminal proceedings. ${ }^{67}$ Core notions of the Criminal Procedure Code, such as the principle of compulsory prosecution and the state's commitment to search for truth, limit the parties' capacity to dispose of cases in a much more rigid manner than occurs, for instance, in German civil disputes or in U.S. criminal procedure. ${ }^{688}$ These basic premises of German criminal justice impose several restrictions on the development of consensual arrangements between the parties of criminal proceedings. ${ }^{689}$

According to the principle of compulsory prosecution ("Legalitätsgrundsatz"), prosecutors are required to press charges whenever there is enough evidence to support a conviction, and exceptions to this rule must be ex-

687 Bernd Schünemann points out that, while inter-party negotiations represent a common feature of German civil procedure and of Anglo-Saxon criminal justice, basic principles of German criminal procedure traditionally ruled out the adoption of negotiated solutions between parties. See: Schunemann, 'Die Verständigung im Strafprozeß - Wunderwaffe oder Bankrotterklärung der Verteidigung?' (n 27) 1896.

688 Thomas Weigend observes that "according to the German understanding - and in contrast to the Anglo-American concept of criminal procedure - a judicial verdict on a criminal proceeding cannot be legitimized by a mere consensual arrangement between the parties". See: Thomas Weigend, 'Neues zur Verständigung im deutschen Strafverfahren?' in: Jocelyne Leblois-Happe and CarlFriedrich Stuckenberg (eds.), Was wird aus der Hauptverhandlung? Quel avenir pour l'audience de jugement?, (Boon University Press 2014) 199-220.

689 See Hassemer, 'Pacta Sunt Servanda - Auch Im Strafprozess?' (n 679) 892; Brodowski, 'Die verfassungsrechtliche Legitimation des US-amerikanischen "plea bargaining“ - Lehren für Verfahrensabsprachen nach $\$ 257$ c StPO?' (n 24) 733-777. 
pressly provided for by law. ${ }^{690}$ The principle seeks to enforce the state's commitment to fulfill substantive law provision through criminal proceedings and, at the same time, ensure that all individuals receive equal treatment by the criminal justice system. ${ }^{691}$ Therefore, prosecutors must strictly follow the objective criteria established by legislation and cannot dispose of the state's obligation in prosecuting suspicious acts. ${ }^{692}$

The parties' capacity to negotiate in German criminal procedure has also been limited by the understanding that the state has the obligation to determine correctly the facts of the investigated conduct, ${ }^{693}$ a duty that is achieved by the assignment of a central role to the judge in the process of fact-finding. ${ }^{694}$ The Criminal Procedure Code determines that courts must extend the gathering of evidence to all the important facts and evidence for establishing the truth. ${ }^{695}$ This is the so-called principle of state investigation ("Amtsermittlungsgrundsatz"), according to which the judiciary is responsible for the conduction of a full factual investigation after the opening of a criminal proceeding. ${ }^{696}$ This principle does not mean that investigative efforts must create absolute certainty about what has occurred, but rather that there is an obligation on the part of the judiciary to guarantee a

690 As provided in the German Code of Criminal Procedure (StPO), $\$ 152(2)$.

691 Thomas Weigend, 'Das „ Opportunitätsprinzip " Zwischen Einzelfallgerechtigkeit Und Systemeffizienz' (1997) 109 Zeitschrift für die gesamte Strafrechtswissenschaft 103, 104.

692 Julia Peters notes that the German Federal Constitutional Court has linked the principle of compulsory prosecution with the prohibition on arbitrary actions of state officials ("Willkürverbot") (See: Peters (n 680) 28-29.

693 Noting the restrictions that arise from the state's commitment to search for truth in criminal procedure, particularly in comparison the the U.S. system of plea bargaining, see: Martin Heger and Hannah Kutter-Lang, Strafprozessrecht (Verlag W. Kohlhammer 2013) 7-8.

694 Bernd Schunemann, 'Die Zukunft Des Strafverfahrens - Abschied Vom Rechtsstaat?' (2007) 119 ZStW 945, 946. Analyzing the German criminal procedure, Martin Heger notes that "During the preliminary investigation, the main responsibility to unearth the truth lies with the district attorney's office. After the proceedings have entered the trial stage, this responsibility is handed over to the court. As a result, witnesses are always named and subpoenaed by the court and later questioned by the judge during trial". See: Heger (n 25) 202.

695 German Code of Criminal Procedure (StPO), $\mathbb{2} 244$ (2).

696 As Klaus Malek points out, one of the main repercussions of the principle of state investigation regards the role of the judicial bodies in the process of factfinding. See: Malek (470). 
thorough investigation of the facts. ${ }^{697}$ In this context, the confession of the accused is not enough to end the official investigation, which must confirm through objective means the guilt of the defendant even when he has admitted to committing the investigated acts. ${ }^{698}$

The traditional basis of the German criminal procedure, therefore, greatly differs from the foundations of the U.S. system of criminal justice, which is based on an adversarial model of fact-finding, and on the parties' capacity to dispose of the process. ${ }^{699}$ The American system of dialectical opposition of alternative factual narratives presented by each of the parties contradicts, in different aspects, the continental model of assigning to law enforcement authorities, and in particular to judges, the duty to investigate the offense in the best possible manner. ${ }^{700}$

A main consequence of this structural differences concerns the powers of negotiation with which U.S. criminal procedure vests the prosecutors and defendants. ${ }^{701}$ In the United States, consensual solutions are common and widespread, given that criminal proceedings are mainly understood as a conflict between prosecution and defense, mediated by a passive judge. ${ }^{702}$ The wide for negotiation between prosecutors and defendants en-

697 On this matter, the German Constitutional Court has decided that "The criminal process has to fulfill the principle of culpability and must not depart from its intended goal of the best possible investigation of the material truth and the assessment of the factual and legal situation by an independent and neutral court.” BVerfG, Urt. v. 19.3.2013 - 2 BvR 2628/10 u.a. = BVerfGE 133, 168, para 102.

698 Winfried Hassemer, 'Konsens Im Strafprozeß' in Regina Michalke and others (eds), Festschrift für Rainer Hamm zum 65. Geburtstag am 24. Februar 2008 (De Gruyter 2009) 187. Martin Heger observes that "in Germany it is not up to the opposing parties to convince the court of a certain truth. On the contrary, the only relevant truth is an objective one that remains uninfluenced by a 'guilty plea'”. See: Heger (n 25) 203.

699 For more on the subject see: Schünemann, 'Zur Kritik Des Amerikanischen Strafprozessmodells' (n 25). Similarly, Dominik Brodowski asserts that a characteristic of the U.S. criminal justice is the absence of the duty of state authorities to prosecute any known or suspected crimes. See: Brodowski (n 24) 741.

700 Jeßberger (n 1) 160. Comparing the Continental and the Anglo-american systems of criminal justice, Martin Heger highlights two fundamental differences: "1) the working relationship between the judge and the other parties to the proceedings and 2) a vastly different expectation of the court's responsibility to ascertain the truth of a case". See Heger (n 25) 199.

701 For a thorough exam, see: Weigend, Absprachen in Ausländischen Strafverfahren: Eine Rechtsvergleichende Untersuchung Zu Konsensualen Elementen Im Strafprozess (n 24).

702 Langer (n 28) 35-36. 
ables the conclusion of several types of agreements, with different purposes, objectives and contents. ${ }^{703}$ The agreement may concern the types of charges the prosecutors will press, the sentence to be served by the accused and may or may not regulate the cooperation of the accused in the investigation of crimes committed by others. ${ }^{704}$ Given the view that criminal cases are similar to disputes between parties, consensual solutions can be understood as normal and even desirable mechanisms within U.S. criminal justice. ${ }^{705}$

Throughout much of the 20th century, ${ }^{706}$ German criminal procedure did not enable the creation of a negotiation forum for procedural parties to consensually define the outcome of criminal proceedings, in marked contrast to the U.S. experience with the evolution of plea bargaining, ${ }^{707}$ which gained a prominent role in the American justice system from the beginning of the last century. ${ }^{708}$ Given the foundations of German criminal procedure, especially the principle of compulsory prosecution and the state's commitment to search for truth, this scenario was to be expected. After all, what was the possibility of development of consensual solutions in a system of criminal justice where prosecutors could not make discretionary decisions regarding the pressing of charges, defendants could not dispose of the proceeding through a confession and courts were required to carry out, in an independent manner, a meticulous fact-finding process?

703 According to James Whitman American prosecutors "bring the same spirit of inventiveness to their task that American business lawyers bring to the drafting of contracts". See Whitman (n 244) 387.

704 Alschuler (n 42) 3-4. Also noting, critically, the enormous space for negotiations held by the parties in American criminal justice: Greco, Strafprozesstheorie Und Materielle Rechtskraf (n 668) 265-266.

705 As noted by the U.S. Supreme Court: "Whatever might be the situation in an ideal world, the fact is that the guilty plea and the often concomitant plea bargaining are important components of this country's criminal justice system. Properly administered, they can benefit all concerned" (UNITED STATES, Supreme Court. Backledge v. Allison, No. 75-1693, 431 U.S. 63, 71, 1977).

706 While it is difficult to pinpoint the time when agreements became common in German criminal proceedings, the doctrine points out that the discussion about the issue only started to gain traction from the 1980s. As Julia Peters observers, prior to this period, studies on agreements in the German criminal procedure were very scarce, and jurisprudential references to the subject were also rare. See Peters (n 680) 7-8.

707 For a historical view of these contrasts, see Langbein (n 682). For a more current comparison, see Brodowski (n 24).

708 On the subject, see Alschuler (n 42). 
b. Development of the practice of negotiated judgments

A surprising answer to this question appeared in 1982, in an article published by a defense lawyer under a pseudonym, which denounced the spreading of informal agreements in the German criminal justice system. ${ }^{709}$ According to the article, in numerous complex cases, the conviction of defendants stemmed not from a thorough and public process of fact-finding, but rather from consensual solutions negotiated, in an informal manner, by prosecutors, defendants and courts. The article criticized the silence of the legal community in relation to the subject, since - according to the author - virtually all legal practitioners knew of and participated in the practice of informal negotiated judgments, but no one talked about it. ${ }^{710}$

The article drew attention to the development, through judicial practice, of informal negotiated judgments in the German justice system. ${ }^{711} \mathrm{~A}$ survey conducted in 1987 with more than a thousand judges, lawyers and prosecutors indicated that a significant portion of criminal convictions were reached through informal agreements, a phenomenon that occurred especially in investigations of economic crimes, in which the defendants' legal status was uncertain and the discovery phase was lengthy. ${ }^{712}$ Other empirical studies demonstrated the widespread existence of informal agreements and revealed the expansion of the practice of consensual solutions in the German criminal justice system, ${ }^{713}$ particularly in cases regarding economic crimes and drug trafficking. ${ }^{714}$

Since these consensual solutions stemmed not from a legislative amendment or from a specific judicial decision, but rather from routines of informal communication between procedural participants, it is difficult to determine the exact moment this negotiating practice emerged. ${ }^{715}$ Further-

709 Deal (n 687).

710 ibid 545 .

711 Because of the informal nature of this practice, it is difficult to identify exactly the period of its inception. See Heger and Kuterrer-Lang (n 694) 82.

712 Schünemann, 'Die Verständigung Im Strafprozeß - Wunderwaffe Oder Bankrotterklärung Der Verteidigung?' (n 27) 1896.

713 For an overview of these studies, see: Patricia Rabe, Das Verständigungsurteil Des Bundesverfassungsgerichts Und Die Notwendigkeit von Reformen Im Strafprozess (Mohr Siebeck 2017) 275-277.

714 Altenhain, Dietmeier and May (n 38) 20.

715 For an overview of the first decisions examining the legality of informal agreements in criminal proceedings, see: Peters (n 681) 32-45. According to the author, the practice of negotiated judgments was only perceived with greater at- 
more, given the clear incompatibility of these negotiated judgments with the formal rules of the German Criminal Procedure Code, legal practitioners opted for discretion and secrecy, preventing the identification of such practice. However, several elements indicate that, as early as the 1970s, there were cases in which the conviction of the accused was preceded by informal agreements. ${ }^{716}$

Given the lack of a statutory basis and the traditional structure of German criminal procedure, the practice of negotiated judgments adopted a very specific format, quite different from the U.S. system of plea bargaining. In the German model of informal transactions in criminal proceedings, the negotiation process involved not only the prosecution and the defendant, but also the judge, who would often take the initiative of starting the negotiations, playing an active role in defining the content of the agreement. ${ }^{717}$ The agreements were discussed and concluded in private, without following defined formalities and leaving no written record. ${ }^{718}$

In these negotiations, the judge, with the consent of the prosecutor, offered the defendant a reduced sentence, conditional upon confession of the facts under investigation. ${ }^{719}$ In many cases, two scenarios were presented to the defendant: in one, the defendant would enter into an agreement, confess to the crimes and obtain a reduced sentence; in the other, the proceeding would follow its regular course and could result in more severe penalties. In view of this practice, known as sanctioning scissors ("Sanktionsschere"), the accused would either accept the deal and secure a reduced sentence or opt for the continuance of the proceeding and face the possibility of receiving a heavier penalty in case of conviction. ${ }^{720}$

Although the factors that led to the development of informal consensual solutions in the German justice system are multiple and complex, a frequently mentioned cause is the increase in the number of investigations related to economic and corporate crimes. ${ }^{721}$ The legislation regarding this

tention when the judiciary began to encounter cases in which the dissatisfaction of the parties with the informal agreement led to judicial questions.

716 Heger and Pest (n 37) 446.

717 Brodowski (n 24) 770.

718 Schünemann, 'Die Verständigung Im Strafprozeß - Wunderwaffe Oder Bankrotterklärung Der Verteidigung?' (n 27) 1895.

719 For a description of the process of informal negotiation, see: Deal (n 687).

720 Eberhard Kempf, 'Gesetzliche Regelung von Absprachen Im Strafverfahren? Oder: Soll Informelles Formalisiert Werden?' (2009) StV 269.

721 Schünemann, 'Gutachten, Kongressvortrag, Aufsatz | Absprachen Im Strafverfahren - Grundlagen, Gegenstande Und Grenzen’ (n 38) 17-18. 
type of criminal behavior had undergone notable expansion since the 1970s, and increased the demands on the criminal justice system, with cases requiring a long and complex factual investigation. ${ }^{722}$ The complexities of the fact-finding process in these situations gave rise to inquiries dubbed "monster proceedings" ("Monster-Verfahren"), that could last for years or even decades. ${ }^{723}$ At the same time, the traditional rules of the Criminal Procedure Code allowed the defense to resort to several manoeuvres that extended the procedure and prevented an expeditious resolution of cases.

In this context, the development of a broad mechanism for consensual arrangements - which were already gaining ground in the German criminal procedure after a 1973 legislative amendment allowed investigations of minor offenses to be resolved through negotiations between the prosecutor and the accused 724 - arose as a solution for the daily problems of legal practitioners, albeit representing a clear departure from the existing statutory rules and the traditional foundations of the German system of criminal justice.

Although the practice of informal consensual solutions appeared and evolved in German criminal procedure as a contra legem or, at least, praeter legem mechanism, ${ }^{725}$ different studies and surveys pointed to a deep entrenchment of this type of negotiation in the justice system. ${ }^{726}$ In the field of economic criminality, the employment of consensual solutions in proceedings became so commonplace that, by the end of the 20th century, most of the cases related to this type of offense were resolved through ne-

722 Weigend, 'Abgesprochene Gerechtigkeit — Effizienz Durch Kooperation Im Strafverfahren?' (n 670) 775.

723 Bernd Schunneman, 'Zur Kritik des amerikanischen Strafprozessmodells' (n 25) 555-575.

724 The 1973 amendment introduced section $\$ 153 \mathrm{a}$ in the German Code of Criminal Procedure, allowing prosecutors to resolve investigations of minor offenses through an agreement with the defendant. As observed by Martin Heger and Robert Pest, this provision is often said to be a "gateway drug for the practice of negotiated judgments". See: Heger and Pest (n 37) 449.

725 In this sense, notes Miriam Prelle: "In the past, agreements in criminal proceedings were not regulated by statute, but they existed praeter legem or contra legem (.... “. See: Miriam Prelle, 'Opportunität Und Konsens: Verfahrensförmige Normsuspendierung Als Hilfe Für Die Überlast Im Kriminaljustizsystem?' (2011) 94 Kritische Vierteljahresschrift für Gesetzgebung und Rechtswissenschaft 331, 350. In the same vein, see: Weigend, 'Abgesprochene Gerechtigkeit - Effizienz Durch Kooperation Im Strafverfahren?' (n 670) 781.

726 For a detailed empirical study, see: Altenhain, Dietmeier and May (n 38). 
gotiated arrangements. ${ }^{727}$ In this type of investigation, the establishment of criminal liability through a thorough and independent investigation of the facts ceased to be the rule and became the exception, while consensual arrangements assumed a central role in the resolution of criminal proceedings. 728

\section{c. Judicial acknowledgement}

The exposure of the informal practice of negotiated judgments spawned intense controversy and received great attention in German legal scholarship. A famous and detailed study presented at the conference of the Association of German Jurists in 1990 not only stated that the practice of consensual solutions contradicted basic principles of the German legal system, but also held that the practitioners responsible for these negotiations were actually committing crimes. ${ }^{729}$ The judicial reaction to the phenomenon of informal agreements, however, was not so critical, as demonstrated by the three main rulings of the German higher courts on the subject, occurred in 1987, 1997 and 2005.730

In 1987, the discussion regarding informal consensual solutions in criminal proceedings reached the German Constitutional Court for the first time. ${ }^{731}$ In a short decision that clearly failed to address a number of legal questions related to the practice, ${ }^{732}$ the Constitutional Court affirmed that

727 Bernd Schünemann, 'Wohin Treibt Der Deutsche Strafprozess?' (2009) 114 Zeitschrift für die gesamte Strafrechtswissenschaft 1, 27. Multiple empirical studies have pointed in this direction. For an overall view, see Peters (n 680) 12-17.

728 For an empirical study regarding the use of negotiated judgments in the field of economic crimes, see Altenhain, Dietmeier and May (n 38).

729 See Schünemann, 'Gutachten, Kongressvortrag, Aufsatz | Absprachen Im Strafverfahren - Grundlagen, Gegenstande Und Grenzen' (n 38).

730 According to Patricia Rabe, the judicial acknowledgment given by German higher courts transformed a "child of the practice" into an "adoptive child of jurisprudence” . See: Patricia Rabe, Das Verständigungsurteil des Bundesverfassungsgerichts und die Notwendigkeit von Reformen im Strafprozess (Mohr Siebeck 2017) $1-2$.

731 See BVerfG, Beschl. v. 27.1.1987 - 2 BvR 1133/86.

732 The German Constitutional Court recognized in subsequent judgements that the 1987 decision failed to resolve the constitutional controversy over the practice of informal agreements. In this regard, the following decision: BVerfG, Beschl. v. 5.3.2012 - 2 BvR 1464/11, para 21. 
the principle of due process did not prevent the parties from negotiating on the status and the prospects of criminal proceedings. ${ }^{733}$ At the same time, the Court affirmed that the practice of negotiated judgments did not relieve judicial bodies of the duty to search for truth and to apply a punishment consistent with the offender's culpability. ${ }^{734}$

In 1997, the German Federal Court of Justice rendered a decision of paramount importance on the issue of consensual solutions, ruling that, although the principles of German criminal procedure forbade certain forms of agreement, negotiations between parties were not intrinsically illegal as long as limits and restrictions were observed. ${ }^{735}$ According to the decision, under no circumstances would judges be relieved of their commitment to search for the truth. The credibility of any confession obtained through an agreement must, therefore, be independently verified and could not lead to an early end to the investigation, preventing the parties from disposing of the verdict on the accused's guilt. ${ }^{736}$ The Court understood that the defendant's confession could be a mitigating factor for determining the sentence, but that agreements could establish the exact criminal punishment, since a consensual solution cannot exempt courts from their obligation to impose a sentence consistent with the offender's guilt.

In its decision, the German Federal Court of Justice also established a series of limits on the format of inter-party negotiations, affirming that the accused's confession could not be obtained through the threat of more severe penalties (as occurred in the practice of "sanctioning scissors") or through the promise of benefits not set forth in law. The Court also determined that agreements could not compel defendants to waive the right to appeal the sentence. In relation to the procedural formalities, the decision stated that any consensual arrangement between parties should be con-

733 See BVerfG, Beschl. v. 27.1.1987 - 2 BvR 1133/86.

734 According to the ruling: "The central concern of criminal procedure is the investigation of real factual circumstances, without which the substantive principle of individual culpability cannot be fulfilled. The goal to investigate the substantive truth, and to decide on this basis on the defendant's guilty and define the legal consequences, is a duty for both courts and prosecutors." See BVerfG, Beschl. v. 27.1.1987 - 2 BvR 1133/86.

735 See BGH, Urt. v. 28.8.1997 - 4 StR 240/97 = BGHSt 43, 195.

736 The decision stated that basic principles of German criminal procedure "exclude from the outset the possibility of an agreement on the verdict of guilty." See BGH, Urt. v. 28.8.1997 - 4 StR 240/97 = BGHSt 43, 195. 
cluded at a hearing before the court and that the final agreement must be formally included in the process. ${ }^{737}$

The 1997 decision was not, however, able to settle all the controversies regarding the practice of informal consensual solutions in German criminal justice. Legal practitioners continued to negotiate without complying with the boundaries defined by the Federal Court of Justice. ${ }^{738}$ In this scenario, the controversies regarding the practice of informal consensual solutions reached the Federal Court of Justice once again in 2005. ${ }^{739}$

In its second main ruling on the subject, the Court reaffirmed that the practice of consensual solutions was not in itself incompatible with the principles of German criminal procedure. According to the decision, without these agreements, the system of criminal justice no longer had the means to meet the social demand for the effective enforcement of criminal law. ${ }^{740}$ Given the lack of resources caused by the rising amount of more complex cases, the functionality of the justice system could not be guaranteed if negotiated judgments were completely banned. ${ }^{741}$ On the other hand, the Federal Court of Justice once more declared the existence of limits for the practice of negotiated judgments within German criminal procedure, since the principles of culpability and due process prevented parties from freely disposing of the state's duty to investigate offenses and from consensually defining the legal qualification of the facts and the appropriate sentence. ${ }^{742}$

According to the decision, a main objective of criminal proceedings is to determine the truth about suspected offenses, which is essential for the rendering of a correct judgement. Given the constitutional requirement to seek the best possible clarification of the facts ("Gebot bestmöglicher Sachaufklärung"), the verdict can only be determined by courts after the conclusion of the discovery phase. ${ }^{73}$ Furthermore, the Court stated that

737 According to the ruling, the practice of informal agreements violated the principle of publicity: "When an agreement is shifted away from the main hearing and is not disclosed, the main hearing becomes just a façade (...)" See BGH, Urt. v. 28.8.1997 - 4 StR 240/97 = BGHSt 43, 195.

738 Altenhain, Dietmeier and May (n 38) 39-40.

739 This time, the case was analyzed by the "Grand Senate for Criminal Matters" ("Großer Senat für Strafsachen"), the highest criminal chamber in the structure of the Federal Court of Justice.

740 See BGH, Beschl. v. 3.3.2005 - GSSt 1/04 = BGHSt 50, 40, para 49.

741 See BGH, Beschl. v. 3.3.2005 - GSSt 1/04 = BGHSt 50, 40, para 50.

742 ibid para 37.

743 ibid para 38. 
the penalty must be established based on the culpability of the offender, the seriousness of the offense and the severity of the facts. ${ }^{74}$ The constitutional principle of the individualization of punishment would prevent the imposition, through a consensual arrangement, of penalties that are either excessively high or excessively low.

After acknowledging that informal consensual solutions were widely used and had developed deep roots in the German justice system, the Federal Court of Justice appealed to the legislature to set statutory limits and conditions for the practice. ${ }^{745}$ According to the Court, the difficult answers to the various questions concerning the employment of consensual mechanisms in the German criminal procedure would be better provided by a legislative measure rather than by judicial decisions.

\section{d. The legislative regulation of negotiated judgments}

In 2009, four years after the Federal Court of Justice's decision, the German Parliament approved a statute regulating the use of negotiated judgments in criminal proceedings. The legislative proposal acknowledged that the practice among defendants, prosecutors and judges of negotiating over criminal verdicts and sentences had emerged informally in the German criminal system decades earlier. ${ }^{76}$ The bill emphasized that the Constitutional Court, in 1987, and the Federal Court of Justice, in 1997 and 2005, considered the practice of negotiated judgments legitimate as long as some limits associated with traditional principles of German criminal procedure - such as the state's commitment to search for truth, the principle of culpability and the guarantee of due process - were respected. ${ }^{747}$ The purpose of the bill was to devise a statutory framework for negotiated judgments that provided legal certainty for the practice and, at the same time, preserved the principles of German criminal procedure. ${ }^{748}$

In that context, the response of the German Parliament to the demand for consensual solutions within criminal procedure was not to make struc-

744 ibid para 39.

745 ibid para 81.

746 See the bill proposed by the German Federal Government: Deutscher Bundestag, 'BT-Drucksache 16/12310' (18 March 2009), 1.

747 ibid 7-8.

748 "According to the legislative proposal: The aim of this bill is in particular to regulate negotiated judgments so that they comply with the traditional principles of German criminal proceedings" (ibid. 1). 
tural changes in the criminal justice system, ${ }^{749}$ as had happened, for instance, in Italy. ${ }^{750}$ The development of a statutory framework for consensual solutions in Germany occurred through the addition of specific provisions and minor amendments to the Criminal Procedure Code. ${ }^{751}$ The legislative regulation largely reflected the guidelines present in previous judicial rulings on the practice of negotiated judgments, in particular the 2005 decision of the Federal Court of Justice. The main change was the introduction of section $\$ 257 \mathrm{c}$ in the German Code of Criminal Procedure $(\$ 257 \mathrm{c}$ StPO), which allows courts to negotiate with the parties over the course and the outcome of a proceeding. ${ }^{752}$

Unlike the U.S. system of plea bargaining, where the negotiation of a consensual solution is primarily performed by the procedural parties (prosecution and defense) and the judge plays a passive role, ${ }^{753}$ the model established by the German legislature gives courts a central role in conducting negotiations in criminal justice. ${ }^{754}$ According to $\$ 257$ c StPO, the court is responsible for delimiting and announcing what content an agreement may have, which can include an upper and a lower limit for the sentence. ${ }^{755}$ After the court announces the possibilities for the conclusion of an agreement, the parties express their opinion about the proposal. When

749 According to Jahn, it is clear that the objective of the new regulation was not to introduce a new and unknown form of consensual procedure. See: Jahn and Müller (n 679) 2631.

750 On the subject, see: Stefano Maffei, 'Negotiations "on Evidence” and Negotiations "on Sentence": Adversarial Experiments in Italian Criminal Procedure' (2004) 2 Journal of International Criminal Justice 1050.

751 The impacts of the changes promoted by the new legislation were very significant. According to Heger and Pest, the regulation of negotiated judgments "represent one of the most significant modifications of the criminal procedure since 1877". See Heger and Pest (n 37) 447.

752 Luis Greco notes that this provision is the centerpiece of the statutory regulation of negotiated judgments. See Greco, "Fortgeleiteter Schmerz" Überlegungen zum Verhältnis von Prozessabsprache, Wahrheitsermittlung und Prozessstruktur' (n 26) 3.

753 On this matter, Maximo Langer observes that "American plea bargaining, assumes an adversarial conception of criminal procedure as a dispute between two parties facing a passive decision-maker. It makes sense in a dispute model that the parties be allowed to reach an agreement over a plea bargain. That is, the parties may negotiate in order to reach such an agreement, and if the parties agree that the dispute is over, the decision-maker should not have any power (or only a relatively minor and formal power) to reject this decision”. See: Langer (n 28) 35-36.

754 Dominik Brodowski (n 24).

755 German Code of Criminal Procedure (StPO), $\$ 257 \mathrm{c}(3)$. 
they agree with the court's proposal, the agreement becomes valid. ${ }^{756}$ In any case, the accused's confession is an essential part of the agreement. ${ }^{757}$

While providing for the possibility of legitimate negotiations in criminal proceedings, the 2009 legislative regulation also imposed a series of limits on the consensual resolution of criminal investigations, similar to the restrictions imposed by prior decisions by German higher courts. $\$ 257 \mathrm{c}$ StPO expressly provides that the defendant's guilt cannot be defined by the agreement. ${ }^{758}$ The legislative proposal emphasized that none of the amendments changed the provision of $\$ 244$ (2) of the German Code of Criminal Procedure, which determines that courts have the duty to seek, ex officio, the truth about the facts through all possible means. ${ }^{759}$ The bill expressly rejected the possibility of creating a new procedural form based on consensual exchanges, asserting that such an option would undesirably reduce the role played by courts in the search for truth in criminal proceedings. ${ }^{760}$ Thus, according to $\$ 257 \mathrm{c}$ StPO, the conclusion of an agreement does not constitute a sufficient basis for establishing the occurrence of a crime or for the imposition of criminal punishment on the accused, which continues to depend on a comprehensive investigation into the suspicious facts.

The statutory framework for consensual solutions also forbade the definition of the exact penalty in the agreement, and allowed only for the establishment of the minimum and maximum sentence. ${ }^{761}$ The reaching of an agreement does not exempt the court from applying the appropriate penalties on the defendant according to the general sentencing rules and the specific circumstances of each case. ${ }^{762}$ According to $\$ 257 \mathrm{c}$ StPO, the agreement will no longer be binding on the court if there are elements that indicate that the consensual arrangement leads to a sentence that is not consistent with the investigated facts or with the accused's culpability. ${ }^{763}$ In that case, the court must immediately inform the parties and the defendant's confession can no longer be used.

756 ibid.

757 ibid $\$ 257 \mathrm{c}(2)$.

758 ibid. In this sense, the 2009 amendment did not introduce the mechanism of "guilty plea". See: Heger (n 25) 200.

759 See the bill proposed by the German Federal Government: Deutscher Bundestag, 'BT-Drucksache 16/12310' (18 March 2009), 8.

760 ibid. 8. On this point, see Jahn and Müller (n 679) 2631.

761 German Code of Criminal Procedure (StPO), \$257c (3).

762 As expressly provided by the bill proposed by the German Federal Government. See Deutscher Bundestag, 'BT-Drucksache 16/12310' (18 March 2009), 14.

763 German Code of Criminal Procedure (StPO), $\$ 257 \mathrm{c}(4)$. 
The legislative regulation also provided that a waiver of the defendant's right to appeal cannot be established in the agreement. ${ }^{764}$ In addition, whenever a negotiation occurs, the court must expressly inform the accused that he or she still has the right to appeal against the decision. ${ }^{765}$ According to bill that introduced the regulation, these provisions seek not only to guarantee the individual rights of the accused, but also to ensure effective judicial control by higher authorities. ${ }^{766}$

Lastly, the 2009 statutory rules sought to change the informal and oral nature of the practice of negotiated judgments, through the establishment of duties regarding the documentation and written record of the negotiation process. To this end, the existence and result of a negotiation must be recorded in the proceeding, even when the parties have not reached an agreement. ${ }^{767}$ The court's chairperson has the duty to publicly announce and record the existence of negotiations for a possible agreement. ${ }^{768}$ In the event that an agreement is concluded, this must be expressly stated in the court's final decision. ${ }^{769}$

The legislative regulation of consensual solutions provoked differing reactions: while some critics perceived that the new rules legitimized a mechanism that contradicted the essence of the German criminal procedure, maximizing the relevance of consensual arrangements while ignoring various known risks, ${ }^{770}$ others argued that the statutory rules merely represented belated approval of an entrenched practice that, in addition to being legitimate, urgently needed to be regulated ${ }^{771}$. Due to the intense controversies regarding the practice of consensual solutions and their legislative regulation, it was only a matter of time before challenges regarding the constitutionality of the 2009 statutory rules reached the German Constitutional Court, which eventually occurred in 2013.

764 ibid $\$ 302(1)$.

765 ibid $\$ 35$ a.

766 See Deutscher Bundestag, 'BT-Drucksache 16/12310' (18 March 2009), 2.

767 German Code of Criminal Procedure (StPO), $\mathbb{} 273$ (1a).

768 ibid $\$ 243(4)$.

769 ibid $\$ 267(5)$.

770 For example: Karsten Altenhain and Michael Hairmel, 'Die gesetzliche Regelung der Verständigung im Strafverfahren - eine verweigerte Reform' (2010) 65 JZ 327, 336-337; Malek (n 470) 565-567.

771 See: Matthias Jahn and Martin Muller, 'Das Gesetz zur Regelung der Verständigung im Strafverfahren - Legitimation und Reglementierung der Absprachenpraxis' 62 Neue juristische Wochenschrift 1; Similarly, but less emphatic: Heger and Pest (n 37) 485-486. 
e. The 2013 ruling of the German Constitutional Court

In 2013, the German Constitutional Court was requested to rule on the constitutionality of the statutory framework for consensual solutions in criminal proceedings. The judgement examined constitutional complaints brought by defendants convicted by the Regional Courts of Berlin and Munich after entering into agreements based on $\$ 257 \mathrm{c}$ StPO. ${ }^{772}$ The complaints argued, in short, that the lower courts had failed to comply with the requirements of $\$ 257 \mathrm{c}$ StPO and, simultaneously, violated constitutional rights, such as the principle of due process and the right against selfincrimination. In a detailed decision, the German Constitutional Court decided that the agreements violated the rights of the accused and compromised constitutional guarantees.

Regarding the ruling of the Regional Court of Munich, the Constitutional Court affirmed that the agreements were void due to a violation of the defendant's right to be informed of the limited binding effect of the agreement. ${ }^{773}$ The Constitutional Court emphasized that $\$ 257 \mathrm{c}$ StPO creates a situation where the defendant can influence the outcome of the proceedings and, in such a circumstance, the expectation concerning the binding effect of an agreement becomes the basis of the accused's decision to confess. Therefore, the defendant must previously know that the bond created by the agreement upon the judicial bodies is not absolute and the duty to inform this circumstance, as established by $\$ 257$ c StPO, represents not only a procedural rule, but also a true constitutional safeguard of the principle of fair trial and of the fundamental right against self-incrimination. ${ }^{774}$

With respect to the rulings of the Regional Court of Berlin, the Constitutional Court established that decisions violated the principle of individual culpability and the state's duty to search for the truth, since the convictions were fundamentally based on the defendants' confessions. ${ }^{775}$ According to the Constitutional Court, $\mathbb{S} 257$ c StPO did not exempt the courts from the obligation of verify the credibility of a confession through the conduction of a full investigation of the facts. Criminal punishment represents a reaction of the state to blameworthy conduct performed by an indi-

772 See BVerfG, Urt. v. 19.3.2013 - 2 BvR 2628/10 u.a. = BVerfGE 133, 168.

773 ibid para 124.

774 See BVerfG, Urt. v. 19.3.2013 - 2 BvR 2628/10 u.a. = BVerfGE 133, 168, para 125-126.

775 ibid para 128. 
vidual and, without clear and objective evidence regarding the guilt of the defendant, the imposition of criminal punishment violates the principles of human dignity and rule of law. ${ }^{776}$

In order to assess the compatibility of the practice of negotiated judgments under $\$ 257 \mathrm{c}$ StPO with the constitutional principles underlying the German criminal procedure, the Constitutional Court used an empirical study conducted in 2012 by scholars, at the request of the Court itself, with judges, prosecutors and lawyers. ${ }^{777}$ The study showed a delicate scenario in the practice of consensual solutions in the German system of justice, revealing a standard pattern of widespread disregard of the statutory rules by legal practitioners. ${ }^{778}$ For instance, more than half of the judges interviewed believed that the majority of cases settled by agreements did not meet the legal requirements established by $\$ 257 \mathrm{c}$ StPO. ${ }^{779} \mathrm{~A}$ large portion of the respondents stated that they had not always verified the veracity of a defendant's confession and admitted using the practice of "sanctioning scissors". ${ }^{780}$ The study also revealed serious problems concerning the transparency rules and the duty to register the negotiations. ${ }^{781}$

Despite this situation, the Constitutional Court did not rule the provisions of $\$ 257 \mathrm{c}$ StPO unconstitutional. ${ }^{782}$ In the decision, the Court affirmed that the 2009 legislative regulation did not represent the creation of "a new consensual procedural model", but rather an attempt to adjust the practice of agreements without abandoning the constitutional principles of the German criminal procedure. ${ }^{783}$ For the Court, the main idea of the statutory framework for consensual solutions was precisely to impose lim-

776 ibid para 54-55.

777 The study was conducted between April 17 and August 24, 2012, almost 3 years after the enactment of legislative regulation on negotiated judgments. 190 judges from the criminal court, 68 public prosecutors and 76 criminal attorneys were interviewed. A detailed analysis of the empirical study is presented in Altenhain, Dietmeier and May (n 38).

778 For a summary of this scenario, see Altenhain, Dietmeier and May (n 38) 181-184.

779 See BVerfG, Urt. v. 19.3.2013 - 2 BvR 2628/10 u.a. = BVerfGE 133, 168, para 49.

780 Altenhain, Dietmeier and May (n 38) 90-94 and 122-125.

781 In scenarios where no agreement was reached, $54.4 \%$ of the judges stated that, in their opinion, it was not important to formally register the negotiation. When an agreement was concluded, $46.7 \%$ did not report the agreement in their decision, contradicting the provision set forth in the stop. See BVerfG, Urt. v. 19.3.2013 - 2 BvR 2628/10 u.a. = BVerfGE 133, 168, para 49.

782 See BVerfG, Urt. v. 19.3.2013 - 2 BvR 2628/10 u.a. = BVerfGE 133, 168, para 64.

783 ibid para 65-67. Praising this part of the decision, Luis Greco asserts that it represented "a definitive rejection of any consensual lyric”. See Greco, '„Fortgeleit- 
its on a tool which had gained importance in the judicial system, but which needed clear legal requirements to avoid compromising traditional pillars of the German justice system. According to the decision, the compatibility of the agreement practice with the legal system must be understood within the strict limits of $\$ 257 \mathrm{c}$ StPO, which safeguard the constitutional principles of the search for truth and culpability. ${ }^{784}$

Consequently, although understanding that the legislative regulation of consensual solutions itself was not unconstitutional, the Constitutional Court rejected the legality of several practices observed by the empirical study. First, the Court affirmed that agreements could never be used as a sole basis for the defendants' conviction. As explicitly stated in the legislation, the judicial bodies remain bound by the duty to seek for truth even after an agreement has been signed. According to the ruling, criminal penalties are responses to blameworthy conduct, and, without solid proofs of a defendant's guilt, the imposition of criminal punishment is incompatible with human dignity. ${ }^{785}$ Thus, the search for truth remains a core notion of the criminal proceeding, preventing the parties from manipulating the fact-finding process and the legal qualification of the investigated conducts. $^{786}$

Moreover, the Constitutional Court emphasized that the defendant had the right not to testify against himself and that the defendant must decide freely whether to enter into an agreement. Therefore, the defendant must be fully informed of the requirements and consequences of a consensual solution, in order to make a conscious decision about the process. Upon receiving a proposal for a maximum penalty from the judge, the defendant must be informed that the agreement is not absolutely binding upon judicial bodies and in which cases the sentence may not reflect the proposal. ${ }^{787}$

The Constitutional Court also stressed that the negotiation of an agreement must comply with the principle of transparency and with the duty of documentation. According to the decision, the registry requirements established in the legislation are not mere formalities, but rather an essential guarantee to enable adequate control of the practice of consensual solu-

eter Schmerz" - Überlegungen zum Verhältnis von Prozessabsprache, Wahrheitsermittlung und Prozessstruktur' (n 26) 11.

784 See BVerfG, Urt. v. 19.3.2013 - 2 BvR 2628/10 u.a. = BVerfGE 133, 168, para 75-76.

785 ibid para 54.

786 ibid para 65.

787 See BVerfG, Urt. v. 19.3.2013 - 2 BvR 2628/10 u.a. = BVerfGE 133, 168, para 125 . 
tions by higher courts. ${ }^{788}$ Thus, the conduction of negotiations that fail to observe the rules of transparency and documentation leads to the nullity of the agreement. ${ }^{789}$

Furthermore, the Court affirmed that an agreement can only generate effects in relation to the investigated facts in the process in which it was concluded. ${ }^{790}$ As a result, the Court determined that "package deals" ("Gesamtlösungen"), a common practice in investigations of economic crimes that allowed for the settlement of different criminal proceedings through a single agreement, were illegal. ${ }^{791}$

At the end of the decision, the German Constitutional Court called the attention of the legislature to the deficit of implementation of the legislative regulation of consensual solutions. ${ }^{792}$ According to the court, if judicial practice continues to disregard the material and formal limits set forth in the statute, the legislature must take the necessary measures to solve this problem. In different parts of the decision, the Court indicated that the continuance of the implementation deficit may lead to a future decision declaring legislative regulation of negotiated judgments to be unconstitutional. ${ }^{793}$

\section{The general crown-witness regulation}

In 2009, the year of the enactment of the statutory framework for consensual solutions in criminal justice, the German parliament approved another controversial proposal: the so-called general crown-witness regulation ("allgemeine Kronzeugenregelung"), which amended the German Criminal Code to expand the possibilities for granting benefits to offenders who cooperate in the investigation of crimes committed by other individuals. ${ }^{794}$

788 ibid para 96

789 ibid para. 97

790 ibid para. 79.

791 For an analysis of the decision's impacts on the prosecution of economic crimes, see Andreas Mosbacher, 'Praktische Auswirkungen Der Entscheidung Des BVerfG Zur Verständigung' (2013) 2 BvR 201, 204.

792 See BVerfG, Urt. v. 19.3.2013 - 2 BvR 2628/10 u.a. = BVerfGE 133, 168, para 121.

793 Somewhat skeptical on the practical effects of this statement, see Heger and Pest (n 37) 485-486.

794 See the bill proposed by the German Federal Government: Deutscher Bundestag, 'BT-Drucksache 16/6268' (24 August 2007). 
The approval of the legislation came after a long debate, both in the German legislature and in legal scholarship. ${ }^{795}$

As with the evolution of consensual solutions in German criminal justice, the introduction of the general crown-witness regulation in German criminal law faced several obstacles. Unlike the U.S. criminal system, where cooperation between defendants and law enforcement authorities has developed into a common practice due to peculiarities of the partydriven criminal procedure, basic pillars of German criminal justice have for a long time hindered the development of these cooperative relationships. ${ }^{796} \mathrm{~A}$ recurrent objection raised against the employment of cooperating defendants in Germany stemmed from the principle of compulsory prosecution, aimed at securing a thorough enforceability of substantive criminal law as well as safeguarding the uniformity of criminal prosecution. ${ }^{797}$ Given that the granting of benefits leads to a clear differentiation of treatment between the cooperator and other defendants, the practice inevitably raises concerns regarding the guarantees of equal treatment and of prohibition of arbitrary action that constitute core principles of German criminal justice. ${ }^{798}$

Despite the constraints arising from the structure of German criminal procedure, the employment of cooperating defendants has, in the final decades of the 20th century, gained ground in specific fields and, since the enactment of the 2009 general crown-witness regulation, is regulated in the German Criminal Code. This section examines this evolution and highlights some crucial aspects of the German experience with the development of cooperative relationships between defendants and law enforcement authorities. Item IV.3.a gives a brief overview of the development of the crown-witness regulation in modern German criminal law, from the 1982 amendment of the German Narcotics Law to the recent introduction, in 2009, of the general crown-witness regulation in the German Criminal Code. Item IV.3.b analyzes the structure of the exchange between the state

795 See Buzari (n 12) 45-46.

796 On this point, see Jaeger (n 3) 274; Jeßberger, Kooperation Und Strafzumessung: Der Kronzeuge Im Deutschen Und Amerikanischen Strafrecht (n 1) 153-154.

797 The principle of compulsory prosecution has been often cited as a major obstacle to the development of leniency policies in Germany criminal law. See Hassemer, 'Kronzeugenregelung Bei Terroristischen Straftaten Thesen Zu Art. 3 Des Entwurfs Eines Gesetzes Zur Bekämpfung Des Terrorismus' (n 11) 552; Jaeger (n 3 ) 54-65.

798 Jeßberger, Kooperation Und Strafzumessung: Der Kronzeuge Im Deutschen Und Amerikanischen Strafrecht (n 1) 111-113. 
and defendants under the crown-witness regulation. Item IV.3.c lays out the circumstances in which the crown-witness regulation may be employed and presents the concept of 'investigative emergency' ("Ermittlungsnotstand"). Item IV.3.d advances the concepts of investigatory achievement' ("Aufklärungserfolg") and 'essential contribution' ('wesentlicher Beitrag") as central vectors in the German experience with cooperating defendants. Item IV.3.e describes the 2013 legislative amendment that introduced the connection requirement ("Konnexitätserfordernis") in the general crown-witness regulation, limiting the granting of benefits to inside cooperators ("interne Kronzeuge").

\section{a. Development}

In the last decades of the 20th century, there has been a growing preoccupation in German criminal law with new forms of offenses, in particular with organized crime and terrorism. ${ }^{799}$ Terrorist acts on German soil encouraged legislative reforms to enable a more efficient reaction from public officials. ${ }^{800}$ The emergence of criminal groups dedicated to committing serious offenses in a professional, stable and business-like manner prompted demand for new investigative tools. ${ }^{801}$ This movement led to a gradual change in various parts of German criminal law, both in its substantive and procedural aspects, in order to empower law enforcement authorities in the investigation and prosecution of these new forms of crime. ${ }^{802}$

799 Concerns with organized crime and terrorism have represented the central reasons for the development of the crown-witness regulation in Germany. See Schlüchter (n 495) 69; Buzari (n 12) 29-32; Frahm (n 482) 25-30.

800 For a description of this scenario, see Breucker and Engberding (n 11) 11-16. For a critique regarding this trend, see: Hassemer, 'Kronzeugenregelung Bei Terroristischen Straftaten Thesen Zu Art. 3 Des Entwurfs Eines Gesetzes Zur Bekämpfung Des Terrorismus' (n 11).

801 Klaus von Lampe, ,'Bekämpfung Der Organisierten Kriminalität' (2010) 3 SIAK-Journal - Zeitschrift für Polizeiwissenschaft und polizeiliche Praxis 50, 788.

802 Tatjana Hörnle, in a very critical way, notes that the alleged need to combat terrorism and organized crime constituted the main grounds for several changes in the criminal justice system, both in material and procedural aspects. See: Tatjana Hörnle, 'Die Vermögensstrafe: Ein Beispiel für die unorganisierten Konsequenzen von gesetz- geberischen Anstrengungen zur Bekämpfung organisierter Kriminalität' (1996) 108 Zeitschrift für die gesamte Strafrechtswissenschaft 333. 
It is in this context that, in 1982, a legislative amendment was approved and introduced: section $\ 31$ in the German Narcotics Law ( $\$ 31 \mathrm{BtMG}$ ), allowing the granting of benefits to offenders who cooperate with law enforcement authorities in the investigation of other individuals. ${ }^{803}$ This is the first crown-witness regulation (Kronzeugenregelung) in modern German criminal law, although there were already prior experiences in judicial practice of granting benefits to offenders who cooperated in prosecutions against accomplices. ${ }^{804}$ With the objective of allowing law enforcement authorities to penetrate the sealed structures of drug trafficking organizations ${ }^{805}$ the legislative amendment restricted the employment of the crown-witness regulation to the investigation of crimes under the German Narcotics Law. ${ }^{806}$

The crown-witness regulation introduced in 1982 allowed courts to reduce the sentences of offenders who voluntarily disclosed their knowledge to law enforcement authorities, contributing to exposing crimes that had already occurred or to the prevention of offenses not yet committed. ${ }^{807}$ The regulation did not set specific limits for this reduction, but it explicitly allowed courts to refrain from applying any criminal punishment in cases where the imprisonment penalties were three years or less. ${ }^{808}$ Nor did it allow prosecutors to dispose of the criminal procedure in order to encourage the cooperation of the offender, unlike what had been proposed in previous bills that were not approved. ${ }^{809}$

The 1982 crown-witness regulation established a tool to be used mainly by judicial bodies. ${ }^{810}$ Thus, it did not foresee the possibility of written

803 For a thorough analysis of the changes and challenges brought by the 1982 amendment to the German Narcotics Law, see Jaeger (n 3).

804 Jeßberger, 'Nulla Poena Quamvis in Culpa: Ammerkungen Zur Kronzeugenregelung in $\$ 46 \mathrm{StGB}$ ' (n 2) 1155.

805 Buzari (n 12) 33.

806 More specifically, the crimes provided for in German Narcotics Law (BtMG) $1981, \mathbb{2} 29$ para $3, \mathbb{} 29$ a para $1, \mathbb{} 30$ para $1, \mathbb{3 0 a}$ para 1 , which generally cover the most serious forms of crimes provided for in German drug trafficking legislation.

807 German Narcotics Act $(B t M G)$ 1981, $\mathbb{3} 31$.

808 German Narcotics Act $(B t M G)$ 1981, $\$ 31$.

809 A bill proposed by the Nordhein-Westfallen State in 1975 sought to allow the Public Prosecution Office to dispose of criminal procedure as a reward to cooperating defendants in the prosecution of terrorist acts. However, the bill was rejected by the German Parliament. See Deutscher Bundestag, "Drucksache 7/ 4005" (1 September 1975).

810 Jaeger (n 3) 152. 
agreements between the offender and law enforcement authorities, nor did it establish any role for the police or the Public Prosecution Office in the granting of benefits to cooperators. It also did not set any procedural rule by which the cooperation of the offender should occur, nor define the procedural moment at which such cooperation should take place. ${ }^{811}$

Throughout the 1980s, there was a growing debate on the need to extend the crown-witness regulation to other fields of criminality. In 1989, an autonomous legislation was approved - the Crown-Witness Act (Kronzeugengesetz) - which allowed the granting of benefits to offenders who cooperated with investigations of terrorist activities. ${ }^{812}$ Besides allowing the courts to reduce the penalties of cooperators, the legislation also allowed prosecutors to dispose of criminal proceedings in cases where the cooperation provided by the offender was of great relevance. ${ }^{813}$ In 1994 , as part of broad legislative reform of criminal law and criminal procedure aimed at providing more effective control of new forms of crime, the 1989 Crown-Witness Act was amended to enable its use in the investigation of organized crime, and not only terrorist acts. ${ }^{814}$ In 1999, amidst criticism regarding the compatibility of the crown-witness regulation with German law and its lack of practical usefulness, the Crown-Witness Act expired. ${ }^{815}$

After the expiration of the Crown-Witness Act, various parliamentary initiatives sought to introduce wider possibilities for granting benefits to offenders who cooperated with official investigations. ${ }^{816}$ In 2009, ten years after the expiration of the Crown-Witness Act, a bill was approved establishing a more extensive mechanism for granting benefits to offenders who cooperate with criminal prosecution. Before its approval, the bill was harshly criticized by the legal community. Several organizations of lawyers and judges questioned the initiative, stating that the bill undermined the objectives pursued by criminal law, affected the interests of victims and

811 Harald Hans Körner, 'Der Aufklärungsgehilfe Nach $\$ 31$ BtMG' (1984) Strafverteidiger 217, 218.

812 German Crown-Witness Act (StGBuaÄndG) 1989.

813 German Crown-Witness Act $(S t G B u a A ̈ n d G)$ 1989, art 4 S\$ 1- 2.

814 For a description of the legislative debates regarding this legislative changes, see Breucker and Engberding (n 11) 14-16.

815 Buzari (n 12) 31.

816 For instance, see the bill proposed by the German Federal Council (Bundesrat) in 2004: Deutscher Bundestag, 'BT-Drucksache 15/2771' (24 March 2004). 
generated unjustified disparities in the application of criminal penalties. ${ }^{817}$ However, the introduction of a broader system of cooperation with offenders found strong backing from police authorities and public prosecutors, who had long believed that such a tool was needed for the prosecution of new forms of crime, especially organized criminality. ${ }^{818}$ This support from law enforcement authorities was essential for the approval of the bill, which met a longstanding demand from such agencies. ${ }^{819}$

The 2009 legislative amendment introduced a new section to the German Criminal Code ( $\$ 46 \mathrm{~b}$ StGB), which avowedly sought to solve the problem of lack of incentives for cooperating defendants to share information and evidence with law enforcement authorities. ${ }^{820}$ Unlike previous legislation, which had been aimed at specific types of offenses, $\$ 46 \mathrm{~b}$ StGB established generic rules applicable to different forms of crimes, being, therefore, known as the "general crown-witness regulation". ${ }^{821}$ The 2009 regulation clearly sought to extend the scope of the crown-witness regulation in comparison to the legislation that had expired in 1999. The bill expressly cites, for instance, serious corporate crimes and corruption as offenses in which cooperation with offenders is necessary to enable effective prosecution. ${ }^{822}$ The expansion of the applicability of the crown-witness regulation to these offenses had already been advocated by different scholars, in light of the inherent difficulties in the investigation of corrup-

817 See the joint declaration of the German Judges Federation, German Bar Association, German Federal Bar and the German Association of Defense Lawyers: 'Gemeinsame Erklärung des Deutschen Richterbundes, des Deutschen Anwaltvereins, der Bundesrechtsanwaltskammer und der Strafverteidigervereinigungen' (Berlin 2006) <https:/www.brak.de/w/files/stellungnahmen/August_G emeinsam_Straf-2006.pdf s accessed 18 July 2018.

818 Jens Peglau mentions a survey in which more than $90 \%$ of the police authorities, Public Prosecutor's Office and criminal judges interviewed accepted the need for a broader "Kronzeugenregelung”. See Jens Peglau, 'Überlegungen zur Schaffung neuer „Kronzeugenregelungen““(2001) 34 Zeitschrift für Rechtspolitik 103.

819 In this sense, Stefan König states that $₫ 46 \mathrm{~b}$ StGB was a legislative amendment requested by enforcement authorities and designed for them. See: Stefan König and Geringfügig Fassung, 'Kronzeuge - abschaffen oder regulieren?' (2012) Strafverteidiger 113.

820 See the bill proposed by the German Federal Government: Deutscher Bundestag, 'BT-Drucksache 16/6268' (24 August 2007), 1.

821 Malek (n 481) 201.

822 See Deutscher Bundestag, 'BT-Drucksache 16/6268' (24 August 2007), 1 and 9. 
$\operatorname{tion}^{823}$ and economic crimes, ${ }^{824}$ and the great damage that such practices can cause. ${ }^{825}$

\section{b. Structure}

The 2009 general crown-witness regulation $(\$ 46 \mathrm{~b}$ StGB$)$ designs a relationship of exchange between offenders and the state, in which offenders provide information about unlawful activities committed by other individuals and receive in return a partial or full reduction of their criminal punishment. ${ }^{826}$ The statutory provision foresees two different situations where this exchange can occur: the first regards offenders who contribute to the exposure of a crime already committed; ${ }^{827}$ the second relates to situations where the offender cooperates with authorities to prevent the occurrence of a crime. ${ }^{828}$

In both cases, the benefits obtainable by the offender are the same: partial or full reduction of criminal punishment. The general crown-witness regulation does not provide further benefits for the cooperating defendant, such as limited civil liability, unlike what occurs, for instance, within the German antitrust leniency program. ${ }^{829}$ The structure of $\$ 46 \mathrm{~b}$ StGB largely replicates the model of cooperation with offenders established by section $\$ 31$ of German Narcotics Law ( $\$ 31 B t M G$ ), but with broader scope. ${ }^{830}$

823 See Lejeune (n 12) 88. Also Dölling (n 12) 354-355.

824 Jeßberger, Kooperation Und Strafzumessung: Der Kronzeuge Im Deutschen Und Amerikanischen Strafrecht (n 1) 305.

825 On the damages caused by such wrongdoings, see item II.3.c.

826 Jeßberger, 'Nulla Poena Quamvis in Culpa: Ammerkungen Zur Kronzeugenregelung in $\$ 46$ StGB' (n 2) 1153.

827 German Criminal Code $(S t G B), \mathbb{} \$ 46 \mathrm{~b}(1) 1$.

828 ibid $\$ 46 \mathrm{~b}$ (1) 2 .

829 A reform of the German Competition Act in 2017 allowed beneficiaries of antitrust leniency to obtain benefits in the definition of civil damages. Basically, the reform has determined that leniency beneficiaries can only be sued in civil justice by their own clients (while the other offenders can be sued by anyone harmed by the cartel). See German Competition Act $(G W B), \mathbb{3 3 e}$. This privilege aims to increase incentives for offenders to leave the cartel and cooperate with public authorities. See the explanation notes in the bill that introduced the reform: Deutscher Bundestag, 'BT-Drucksache 18/10207' (7 November 2016), 40.

830 König and Fassung (n 820) 113. 
According to the text of the general crown-witness regulation, the granting of benefits must be carried out taking into account the nature and scope of the disclosed facts, their relevance to the discovery or prevention of criminal offenses, the degree of assistance provided and the seriousness of the investigated crime. ${ }^{831}$ The stated goal of the bill that introduced the $\$ 46 \mathrm{~b}$ StGB is to enable law enforcement authorities to penetrate the sealed structures of criminal organizations and to overcome the difficulties met in the investigation of new forms of crime. ${ }^{832}$

Thus, the reduction of penalties offered by the crown-witness regulation is based on different factors than those considered in other circumstances under which German law allows the reduction of criminal punishment, such as in cases of regret and reparation of damages. ${ }^{833}$ Genuine regret is not expected from the cooperating defendant and the psychological motives that lead him to cooperate are irrelevant. ${ }^{834}$ In the context of the crown-witness regulation, the reduction of penalties is related mainly to the effects that the defendant's cooperation has on offenses committed by third parties, and not on the crimes committed by him. ${ }^{835}$

According to $\$ 46 \mathrm{~b}$ StGB, the offender's cooperation cannot be confined to his own acts. ${ }^{836} \mathrm{~A}$ simple confession of the accused is consequently not enough to justify the obtainment of benefits under the crown-witness regulation; the cooperator must submit information and evidence that strengthens the prosecution of other perpetrators ${ }^{837}$ From the defendant's point of view, the crown-witness regulation opens a third form of procedural behavior, ${ }^{838}$ which differs from both the traditional defensive stance and from the conclusion of an agreement through a simple confession. The cooperating defendant provides information and evidence regarding wrongdoings of other individuals, which are not identical to the conducts carried out by the cooperator. In this respect, the crown-witness regulation

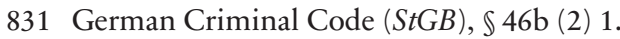

832 See Deutscher Bundestag, 'BT-Drucksache 16/6268' (24 August 2007), 2.

833 Mehrens (n 11) 33-34.

834 Malek, 'Die Neue Kronzeugenregelung Und Ihre Auswirkungen Auf Die Praxis Der Strafverteidigung' (n 481) 201.

835 Jeßberger, Kooperation Und Strafzumessung: Der Kronzeuge Im Deutschen Und Amerikanischen Strafrecht (n 1) 88.

836 German Criminal Code $(S t G B), \$ 46 \mathrm{~b}(1)$.

837 Buzari (n 12) 55.

838 Franz Salditt, 'Allgemeine Honorierung Besonderer Aufklärungshilfe' (2009) Strafverteidiger 375 . 
resembles other investigative strategies, such as the use of undercover agents. ${ }^{839}$

$\$ 46 \mathrm{~b}$ StGB engenders a specific type of exchange between defendants and the state: the exposure by a defendant of a crime committed by another individual is rewarded with a penalty reduction. ${ }^{840}$ The crown-witness regulation exhibits, thus, a clear consensual aspect for both public authorities and defendants. ${ }^{841}$ For public authorities, the granting of benefits to the cooperating defendant is tied to the enhancement of the prosecution of other individuals, resulting from the obtained assistance; for the cooperator, the reduction of penalties appears as a consideration for the disclosure of relevant information and the sharing of evidence against third parties. ${ }^{842}$ Notwithstanding this consensual feature, there is no formal transaction under the crown-witness regulation. $\$ 46 \mathrm{~b}$ StGB stipulates that cooperating defendants must disclose their knowledge voluntarily, but does not provide for a written agreement between the cooperator and public authorities. ${ }^{843}$

Given the structure of German criminal procedure, the development of the exchanges between law enforcement authorities and cooperating defendants occurs in a very different way than in American criminal justice. ${ }^{844}$ U.S. prosecutors have broad discretionary powers regarding charging decisions, which gives them the capacity to make promises to cooperators and honor these commitments through the dropping of charges or their adjustment to less serious accusations. ${ }^{845}$ This scenario is entirely distinct from the traditional structure of German criminal justice, where the principle of compulsory prosecution requires prosecutors to bring charges strictly according to the criteria established in law and judicial bodies play an active role in ensuring a sufficient establishment of the facts, their correct legal qualification and, in case of conviction, the appropriate punishment of the offender. ${ }^{846}$

839 Mehrens (n 11) 29.

840 Jeßberger, 'Nulla Poena Quamvis in Culpa: Ammerkungen Zur Kronzeugenregelung in $\$ 46 S t G B$ ' (n 2) 1153-1154.

841 Salditt (n 839); König and Fassung (n 820) 114.

842 Frahm (n 482) 128.

843 German Criminal Code $(S t G B), \$ 46 \mathrm{~b}$.

844 Jaeger (n 3) 266.

845 Practice known as "charge bargaining". James Whitman speaks of the "inventive discretion" held by American prosecutors. See Whitman (n 244) 387.

846 Ver item V.II.a 
In the context of German criminal procedure, the crown-witness regulation designs a consensual exchange in which the public bodies that obtain the offender's cooperation are not the same authorities responsible for defining and granting the benefits. ${ }^{847}$ In accordance with the rules set by $\$ 46 \mathrm{~b}$ StGB, whereas cooperating defendants must provide assistance to the law enforcement authorities, it is up to courts to determine the cooperators' punishment and the appropriate reductions. Although the statutory regulation establishes some boundaries, judicial bodies can - within these limits - assess different elements in defining the penalties and applying the appropriate benefits. ${ }^{848}$ The 2009 crown-witness regulation did not set any provision authorizing public prosecutors to dispose of criminal charges to favor cooperators. ${ }^{849}$ The granting of benefits, therefore, occurs basically through a judicial decision that acknowledges the relevance and effectiveness of cooperation provided in the prosecution of other individuals, defining the appropriate reward for the cooperating defendant.

The general crown-witness regulation also established a detachment between the moment of cooperation and the moment of obtainment of benefits. According to $\$ 46 \mathrm{~b}$ StGB, privileged treatment is only possible when defendants share their knowledge before the formal beginning of the criminal proceeding. ${ }^{850}$ After this moment, the disclosure of any information cannot lead to the benefits provided for in the crown-witness regulation, but only to other minor advantages established in criminal legislation. ${ }^{851}$ This boundary seeks to give law enforcement authorities enough time to examine the usefulness of the shared material and prevent defendants from withholding information for strategic reasons. ${ }^{852}$ While the information and evidence held by the offender must be shared with public authorities at an early stage of the criminal investigation, the definition and granting of benefits occurs only at the sentencing phase.

Therefore, cooperation with law enforcement authorities, albeit entailing consensual elements, does not create a strict "do ut des" relationship

847 Malek, 'Die Neue Kronzeugenregelung Und Ihre Auswirkungen Auf Die Praxis Der Strafverteidigung' (n 481) 203.

848 German Criminal Code $(S t G B), \$ 46 \mathrm{~b}(2)$.

849 As previously done by the 1989 Crown-Witness Act (Kronzeugengesetz).

850 German Criminal Code $(S t G B), \$ 46 \mathrm{~b}(3)$.

851 Buzari (n 12) 56.

852 As stated in the bill proposed by the German Federal Government that introduced the provision. See Deutscher Bundestag, 'BT-Drucksache 16/6268' (24 August 2007), 14. 
similar to private contracts. ${ }^{853}$ Even though it relies on a voluntary action by the cooperating defendant, the crown-witness regulation - given the central position of judicial bodies in the definition of the criminal sentence and the appropriate benefits - cannot establish a synallagmatic correlation between the acts of cooperation and the concession of benefits. ${ }^{854}$ The obtainment of a penalty reduction by the cooperating defendant is conditional upon a combination of factors that will be assessed by a judicial body at the end of the proceeding, which inevitably creates a degree of uncertainty in the exchange negotiated by the accused and the investigative authorities. ${ }^{855}$

\section{c. Scope of application: investigative emergencies}

The 2009 general crown-witness regulation sets clear limits on the situations in which benefits may be granted to cooperating defendants. The regulation restricts the applicability of the benefits to perpetrators of crimes of medium and high severity, excluding the possibility that individuals responsible for minor offenses become cooperating defendants. ${ }^{856}$ In addition to the restriction on the type of crime committed by the cooperator, $\mathbb{4} 46 \mathrm{~b}$ StGB also establishes conditions for the categories of wrongdoing to be investigated with the aid of the cooperating defendant. According to the statutory text, the crown-witness regulation in only applicable for the investigation of serious criminal offenses. ${ }^{857}$

This position reflects the longstanding view in Germany that cooperation with offenders represents an unusual measure to deal with the formidable obstacles that exist in the prosecution of specific types of crimes, and not a normal routine within the criminal justice system. ${ }^{858}$ Given that the granting of immunity or penalty reductions to offenders

853 Malek, 'Die Neue Kronzeugenregelung Und Ihre Auswirkungen Auf Die Praxis Der Strafverteidigung' (n 481) 203.

854 Frahm (n 482) 132.

855 Jeßberger, 'Nulla Poena Quamvis in Culpa: Ammerkungen Zur Kronzeugenregelung in $₫ 46 \mathrm{StGB}$ ' (n 2).

856 Frahm (n 482) 35.

857 The cooperation must concern investigations of the offenses provided in the catalog of the $₫ 100$ a para 2 of the German Code of Criminal Procedure (StPO), which lists the crimes against which law enforcement authorities are authorized to use wiretapping.

858 Ver: Jung (n 442) 41-42. 
clashes with several principles of German criminal law and procedure, it can only be justified in special situations, commonly referred as 'investigatory emergencies' ("Ermittlungsnotstand"). 859

The reduction of a cooperator's penalties distorts the proportionality that should exist between the commitment of a crime and the application of the penalties provided for in the law. ${ }^{860}$ In this sense, the use of cooperating defendants affects the substance of the principle of compulsory prosecution ("Legalitätsprinzip"), insofar as granting benefits to an offender implies that the penalties resulting from her criminal behavior will be lesser than those established in criminal law. ${ }^{861}$ The reduction of the cooperator's penalty breaks the automatic correlation that must exist between crime and punishment and leads to a gradual departure from the principle of compulsory prosecution. ${ }^{862}$ This departure from the consequences provided for in criminal law appears to be particularly grave when it comes to serious offenses that generate strong social damages. ${ }^{863}$

In this context, the development of the crown-witness regulation can only be justified in the investigation of specific forms of crime, in which there are exceptional obstacles to the enforcement of criminal law. ${ }^{864}$ Even though the granting of benefits to offenders represents a departure from the ideal enforcement of criminal law, the occurrence of investigatory emergencies requires a punctual relaxation of basic pillars of German criminal procedure, in order to guarantee minimal effectiveness of criminal prosecution in particular circumstances. ${ }^{865}$ Thus, the granting of benefits to offenders is legitimate in scenarios where the existence of serious investigative deficits leads to unacceptable situations of impunity, ${ }^{866}$ insofar as it allows for the prosecution and punishment of grave criminal conduct that would otherwise remain without an adequate response from the state. ${ }^{867}$ In contrast, the granting of benefits to cooperating offenders in normal sit-

859 Jeßberger, Kooperation Und Strafzumessung: Der Kronzeuge Im Deutschen Und Amerikanischen Strafrecht (n 1) 304.

860 Nicolas Kneba, Die Kronzeugenregelung Des $\$ 46$ b StGB (Duncker 2011) 36.

861 Hoyer (n 442) 235.

862 Frahm (n 482) 170.

863 Hassemer, 'Kronzeugenregelung Bei Terroristischen Straftaten Thesen Zu Art. 3 Des Entwurfs Eines Gesetzes Zur Bekämpfung Des Terrorismus' (n 11) 552.

864 Jung (n 442) 41-42.

865 Hoyer (n 442) 239-240.

866 Jeßberger, Kooperation Und Strafzumessung: Der Kronzeuge Im Deutschen Und Amerikanischen Strafrecht (n 1) 304.

867 Frahm (n 482) 171-172. 
uations is unacceptable, since it contradicts the state's duty to adequately hold the perpetrators responsible for crimes and, thus, adversely affects the deterrence and preventive effect of criminal law. 868

Thus, unlike U.S. criminal procedure, where cooperation with offenders presents itself as a natural option within the broad discretionary powers held by prosecutors, ${ }^{869}$ in Germany this mechanism is understood as an exceptional one that can be used only in restricted cases. ${ }^{870}$ While the employment of cooperating defendants occurs as an everyday practice in American criminal justice, the German crown-witness regulation can only be implemented in a limited manner to address specific situations of investigatory emergencies ("Ermittlungsnotstand"), characterized by remarkable obstacles in the collection of evidence and severe social consequences of the criminal conduct. ${ }^{871}$

In this way, the granting of benefits to cooperators must rigorously adhere to the legislative rules, which set the specific conditions under which this tool can be used. ${ }^{872}$ On this point, the 2009 general crown-witness regulation, although establishing various restrictions, adopted a broader approach than previous statutes that authorized the use of cooperating defendants in German criminal law. The 1982 amendment of the German Narcotics Law limited the use of cooperating defendants in the investigation of wrongdoings related to drug trafficking. The 1989 Crown-Witness Act originally allowed the granting of benefits to defendants only in investigations of terrorism and was amended, in 1994, to encompass the activities of criminal organizations. The reach of the 2009 general crown-witness regulation is clearly more comprehensive than these previous experiences, authorizing the use of cooperating defendants in the investigation of various types of offense.

An interesting development is the legislative concern with the challenges associated with the prosecution of white-collar criminality: the bill that introduced the general crown-witness regulation specifically asserts that the investigation of "serious corporate crimes" poses a situation where the employment of cooperators is necessary, due to the hermetic nature of these criminal structures. ${ }^{873}$ The bill also mentions corrupt practices as

868 Hoyer (n 442) 235.

869 Jaeger (n 3) 266.

870 Jung (n 442) 42.

871 Jeßberger, Kooperation Und Strafzumessung: Der Kronzeuge Im Deutschen Und Amerikanischen Strafrecht (n 1) 304.

872 Schlüchter (n 495) 69.

873 See Deutscher Bundestag, 'BT-Drucksache 16/6268' (24 August 2007), 9. 
crimes that require the use of this investigatory tool for effective prosecution. ${ }^{874}$ This expansion of the scope of the crown-witness regulation to encompass white-collar wrongdoings reflected a growing concern in German criminal law with the losses caused by corporate and governmental misbehavior and with the major difficulties in the appropriate prosecution of these crimes. ${ }^{875}$

d. Investigative achievements, essential contributions and positive balances

According to the bill that introduced $\$ 46 \mathrm{~b} \mathrm{StGB}$, the offender's cooperation should lead to an investigatory achievement ("Aufklärungserfolg"), that will be observed if the provided material contributes to the establishment of criminal liability of other individuals, regarding conduct that was previously unknown or unclear. ${ }^{876}$ The provision of generic information or of evidence already held by the authorities, the mere speculation on facts and the assertion of versions of events that cannot be proven are, therefore, insufficient to justify granting benefits to cooperators. ${ }^{877}$

The crown-witness regulation engenders a system of exchange between public authorities and offenders in which the latter must not simply confess to their crimes, but also assist in the investigation of criminal conduct attributed to third parties. ${ }^{878}$ The benefits granted to the cooperating defendant result not from the mitigation of damages caused by him or her, but of the ability to effectively assist law enforcement authorities to investigate conduct practiced by third parties. ${ }^{879}$

The crown-witness regulation is a mechanism of utilitarian nature, in which the interest of the state in the negotiation with a cooperating defen-

874 ibid. 1.

875 For a defense of the use of crown-witness regulation in cases of corruption, see: Lejeune (n 12) 88. And also: Dölling (n 12) 354-355. In the same sense, in cases of economic crimes: Jeßberger, Kooperation Und Strafzumessung: Der Kronzeuge Im Deutschen Und Amerikanischen Strafrecht (n 1). 305; Buzari (n 12) 112.

876 See Deutscher Bundestag, 'BT-Drucksache 16/6268' (24 August 2007), 12.

877 Buzari (n 12) 52.

878 Jeßberger, 'Nulla Poena Quamvis in Culpa: Ammerkungen Zur Kronzeugenregelung in $\$ 46 S t G B '$ (n 2) 1153 and 1154.

879 Mehrens, Die Kronzeugenregelung als Instrument zur Bekämpfung organisierter Kriminalität: Ein Beitrag zur deutsch-italienischen Strafprozessrechtsvergleichung (n 11) $33-35$. 
dant is only achieved after obtaining solid results in the prosecution of third parties. For this purpose, the cooperation provided within the scope of the crown-witness regulation must be concrete and precise in order to increase useful knowledge of the law enforcement authorities about other offenders and their participation in criminal acts. ${ }^{880}$ The mere disclosure of information, albeit relevant, is not in itself sufficient to constitute an investigatory achievement, since this depends on an actual impact of the provided cooperation upon the prosecution of other agents. ${ }^{881}$ Thus, the intention and efforts of the offender to help in the investigations do not justify, per se, the granting of benefits provided for in $\$ 46 \mathrm{~b} \mathrm{StGB}$; to substantiate the privileged treatment established by the crown-witness regulation, it is necessary to provide information that effectively assists the criminal prosecution of specific conducts committed by identifiable individuals. ${ }^{882}$

In this context, the sharing of information which only confirms the knowledge that the authorities already have or which concerns minor details of the investigated conduct is insufficient. ${ }^{883}$ The assistance provided by the offender must represent an essential contribution (" wesentlicher Beitrag" ) for the criminal investigation, which means that without the material obtained through cooperation, serious criminal conduct would not otherwise have been exposed, at least not in its entirety. ${ }^{884}$ It is insufficient, therefore, that the information provided by the cooperator to the authorities be truthful, since veracity is not sufficient to ensure an investigatory achievement, which depends on the existence of a verified causal link between the cooperation provided by the offender and a substantial increase in the possibility of conviction of other suspects. ${ }^{885}$

The requirement regarding the achievement of a clear investigatory progress imposes multiple constraints on the employment of the crownwitness regulation. First, it restricts the possibility of granting of benefits to cases where the defendant has valuable material to share with law enforcement authorities. ${ }^{886} \mathrm{In}$ cases in which the accused cannot produce relevant evidence of crimes committed by other individuals, there is no space

880 Kneba (n 861) 66.

881 Frahm (n 482) 51.

882 Malek, 'Die Neue Kronzeugenregelung Und Ihre Auswirkungen Auf Die Praxis Der Strafverteidigung' (n 481) 201.

883 Frahm (n 482) 54-55.

884 Kneba (n 861) 66.

885 Hoyer (n 442) 238.

886 Stephan Cristoph observes that requirement of an investigatory achievement prevents the granting of benefits to cooperating defendants who are unable to 
for the use of the crown-witness regulation. Secondly, the requirement of an investigatory achievement may lead to a race between co-conspirators to be the first to cooperate with law enforcement authorities, since the sharing of redundant information cannot validate the privileges established by the crown-witness regulation. ${ }^{887}$

Besides generating an investigatory achievement, the employment of the crown-witness regulation must maximize the state's capacity to hold the perpetrators of serious crimes accountable. The differentiated treatment of the cooperating defendant is justified only if it brings the level of imposed penalties closer to the ideal established in criminal legislation. ${ }^{888}$ Although the crown-witness regulation leads to reduction of the cooperator's penalty, it should - in an overall view of the criminal justice system - lead to an enhancement of criminal punishment, through the effective and appropriate prosecution of co-conspirators. ${ }^{889}$ Consequently, the reduction of the cooperator's penalties must be compensated by a significant increase in the punishment imposed on other perpetrators who would otherwise remain unpunished. Ultimately, the use of the crown-witness regulation must generate a positive balance in the enforcement system of criminal law. ${ }^{890}$

There is, thus, an inextricable link between the granting of benefits under $\$ 46 \mathrm{~b}$ StGB and the obtainment of unambiguous results stemming from the offender's cooperative behavior in a context of investigatory emergency. It is the attainment of such outcomes that legitimizes a punctual departure from the principle of compulsory prosecution and constitutes the legal basis for the differentiation between cooperative and noncooperative defendants. ${ }^{891}$ Although the veracity and quality of the shared material represent indispensable prerequisites for reaching these results, they are by themselves not enough: multiple factors that are not related to

provide substantial evidence and information regarding crimes committed by other agents. See: Christoph (n 1) 100-101.

887 Buzari (n 12) 52.

888 In order to achieve the goal of "optimale Sanktionierungsrate", according to Heike Jung, in: Jung (n 442) 40.

889 Hoyer (n 442) 236.

890 Jeßberger, Kooperation Und Strafzumessung: Der Kronzenge Im Deutschen Und Amerikanischen Strafrecht (n 1) 102-103.

891 Frahm (n 482) 196; Jeßberger, Kooperation Und Strafzumessung: Der Kronzeuge Im Deutschen Und Amerikanischen Strafrecht (n 1) 113. 
the defendant's behavior stand between the adoption of a cooperative stance and an investigatory achievement. ${ }^{892}$

The actual result of the cooperative effort can only be verified at the end of the criminal proceeding and will be assessed by a different public authority (a judicial body) than the one that received initially the shared material (law enforcement officials). ${ }^{893}$ As in any criminal investigation, the success of an inquiry that relies on cooperating defendants will depend on multiple variables, which makes the use of the crown-witness regulation an uncertain venture for cooperators, who will face alone a large part of the risks in case of any setback. ${ }^{894}$

e. Inside and outside cooperators: the issue of the connection requirement

The 2009 legislative reform that introduced the general crown-witness regulation did not require a connection between the crimes committed by cooperators and the wrongful conduct denounced by them. The cooperation provided by the offender could relate to offenses in which he did not take part, but which he knew of for other reasons. In this context, the offender could help law enforcement authorities in the investigation of a set of offenses and receive the benefits of the crown-witness regulation in a completely different crime. The bill that gave rise to the 2009 reform expressly rejected the establishment of this sort of connection, since the aim was to create a model of broad application for cooperating defendants. ${ }^{895}$

Therefore, the original wording of $\$ 46 \mathrm{~b}$ StGB allowed two distinct groups of offenders to obtain the benefits provided for in the general crown-witness regulation: inside cooperators ("interne Kronzeuge"), who are to some extent accountable for the conducts investigated, and outside cooperators ("externe Kronzeuge"), who help the authorities in investigating crimes in which they did not take part at all. ${ }^{896}$ The knowledge that outside cooperators have about criminal practices may result from diverse

892 Jeßberger, Nulla Poena Quamvis in Culpa: Ammerkungen Zur Kronzeugenregelung in $\$ 46$ StGB' (n 2) 1162.

893 Malek, 'Die Neue Kronzeugenregelung Und Ihre Auswirkungen Auf Die Praxis Der Strafverteidigung' (n 481) 203.

894 Jeßberger, 'Nulla Poena Quamvis in Culpa: Ammerkungen Zur Kronzeugenregelung in $\$ 46 S t G B$ ' (n 2) 1163.

895 See Deutscher Bundestag, 'BT-Drucksache 16/6268' (24 August 2007), 10.

896 Buzari (n 12) 80-81. 
situations, for example, members of criminal organizations that have specific information about the operation of rival groups. ${ }^{897}$

This initial legislative choice was subject of much criticism, both for a possible violation of the principles of German criminal justice as well as the credibility issues of the aid provided by outside cooperators. Regarding the first point, the criticism mainly pointed to an incompatibility of the outside cooperator with the principle of individual guilt, since the absence of a connection requirement would completely erase any relation between the penalty imposed on the cooperator and the degree of his guilt in the crime he committed. ${ }^{898}$ Besides this, the existence of a close relationship between the crime committed by the cooperator and the other offenses investigated should reduce the risk of false statements and ensure that law enforcement authorities obtain detailed inside knowledge of the conduct investigated. ${ }^{899}$

The criticism of the original wording of $\$ 46 \mathrm{~b}$ StGB also resulted from the case law of the German Federal Court of Justice (Bundesgerichtshof$B G H)$, regarding the 1982 crown-witness regulation provided for in the German Narcotics Law $(\$ 31 B t M G)$. Although the text of $\$ 31$ BtMG did not establish the connection requirement between the cooperator's crime and the investigated conducts of third parties, several decisions of the German Federal Court of Justice indicated that the legal mechanism could only be used when there was this factual connection..$^{900}$

In response to such criticisms, a legislative amendment was approved in 2013 to limit the employment of the general crown-witness regulation to situations where the crime committed by the cooperator and the conduct denounced by her are connected. ${ }^{901}$ The amendment was geared to avoid excessive reductions in the penalties of the cooperator, which would be unacceptable from the perspective of the victims of the crime she committed,

897 Johannes Kaspar, 'Stellungnahme Zum „Entwurf Eines...Strafrechtsänderungsgesetzes - Beschränkung Der Möglichkeit Zur Strafmilderung Bei AufklärungsUnd Präventionshilfe“ (BT-Drucks. 17/9695)' (2012) 86135 Augsburg 1, 5.

898 On this subject, see König and Fassung (n 820) 376.

899 For a deeper analysis of this debate, see Stephan Christoph, 'Die „nicht mehr ganz so groBe" Kronzeugenregelung - Anmerkungen zum 46. Strafrechtsanderungsgesetz und zur Auslegung der Konnexitat im Rahmen des neugefassten $\ 46$ b StGB’ (2014) 97 KritV - Kritische Vierteljahresschrift für Gesetzgebung und Rechtswissenschaft 82.

900 Frahm (n 482) 46.

901 Following a bill proposed by the German Federal Government: Deutscher Bundestag, 'BT-Drucksache 17/9695' (18 May 2012). 
as well as to favor the use of the crown-witness regulation in cases in which the cooperator is close to the conduct which she informs against. ${ }^{902}$

Since 2013, therefore, the use of general crown-witness regulation is restricted to cases in which the crime committed by the cooperator is directly related to the investigations in which he assists the law enforcement authorities. According to the bill that restricted the application of $\$ 46 \mathrm{~b}$ StGB, the fact that two crimes were committed by the same organization is insufficient to justify the employment of the crown-witness regulation; for this purpose, the commitment of the two crimes must share more common features than simply the group of perpetrators. ${ }^{903}$ Although the specific limits brought by the legislative amendment are subject to debate, it is clear that the benefits of the general crown-witness regulation can only be granted when there is an "intrinsic and direct relationship" (" ein innerer und verbindender Bezug" ) between the offenses committed by the cooperating defendant and the conducts of third parties that will be investigated with her assistance. ${ }^{904}$

\section{Points of analysis}

Until recently the Brazilian system of criminal justice conceded little space for negotiations between public officials and defendants. Traditional pillars of criminal procedure - such as the principle of compulsory prosecution, the state's commitment to search for truth and the active role played by courts throughout the criminal process - limited the possibility of interparty transactions to cases related to minor offenses, and the full official investigation remained the prevailing model for resolution of criminal cases. The 2013 Organized Crime Act modified this scenario through the introduction of the rewarded collaboration regulation, which created a negotiation forum between law enforcement authorities and defendants willing to cooperate with the investigation.

The swift expansion of the practice of collaboration agreements raised multiple questions regarding the boundaries for the negotiation of consensual arrangements within Brazilian criminal justice. Over recent, legal practitioners have drawn on the rewarded collaboration regulation to set

902 ibid 1.

903 ibid 8.

904 On this point, see the following decision of the German Federal Court of Justice: BGH, 20.03.2014 - 3 StR 429/13, StV 2014, 619. 
up - particularly in the context of complex investigations related to whitecollar crimes - a broad system of transactions, resolving various aspects of criminal proceedings through consensual arrangements. The birth through judicial practice of audacious innovations pushed the limits of the negotiation forum far beyond the provisions of the Organized Crime Act. These novel developments received solid support from Brazilian judiciary and from a section of legal scholarship.

In this context, the German experience with the crown-witness regulation, established in $\$ 46 \mathrm{~b}$ StGB, and with the system of negotiated judgment, regulated in $\$ 257 \mathrm{c} S \mathrm{StPO}$, offer rich elements for a more nuanced analysis of the recent evolution of the rewarded collaboration regulation in Brazilian law. For this purpose, this section examines two topics that will underlie the critical appraisal of the Brazilian practice of collaboration agreements, carried out in Chapter V.

Item IV.4.a compares the objectives and functions of the crown-witness regulation and of negotiated judgments within German system of justice. First, it analyzes the similarities and divergences between the crown-witness regulation and the framework of negotiated judgments (IV.4.a.i) and, secondly, it highlights the different role played by each mechanism in the process of truth-finding in criminal justice, particularly in the context of complex criminal investigations (IV.4.a.ii).

Item IV.4.b examines the German experience with the praeter legem expansion of consensual solutions within the criminal justice system. It highlights the continual pressure put by legal practitioners on the limits of the negotiation forum established by the statutory framework for consensual solutions (IV.4.b.i). It also asserts that the expansion of the negotiation forum may bring benefits for the procedural participants, while producing negative externalities for society and other agents (IV.4.b.ii). Finally, it assesses the ruling of the German Constitutional Court regarding the constitutionality of the legislative regulation of consensual solutions, in a context of widespread disrespect for statutory rules (IV.4.b.iii). 
a The prosecution of economic crimes: between consent and search for truth

i. Negotiated judgments and crown-witness regulation: parallels and differences

The legal rules laid down in $\$ 257 \mathrm{c}$ StPO, which established a statutory framework for negotiated judgments in the German criminal justice system, and in $\$ 46 \mathrm{~b}$ StGB, which introduced a general crown-witness regulation in the German Criminal Code, have clear similarities.

Both provisions impact the traditional dynamic of German criminal procedure, broadening the field of action of procedural participants and allowing them to assume a more active role in criminal proceedings through the adoption of cooperative behavior and the development of consensual exchanges with public officials. ${ }^{905}$ \$257c StPO creates a negotiation forum that allows the parties to deal with each other and reach an agreement concerning the course and the outcome of the criminal proceeding. ${ }^{906}$ The regulation set by $\mathbb{S} 46 \mathrm{~b}$ StGB, although not providing for a formal agreement between the parties, also entails consensual elements, designing a communication channel between law enforcement authorities and defendants to carry out an exchange: the provision of information or evidence in return for a penalty reduction. ${ }^{907}$

Another common feature of the the legal rules established by $\$ 257 \mathrm{c}$ StPO and by $\$ 46 \mathrm{~b}$ StGB relates to the design of new possibilities for the defendant to reach more favorable results in the criminal proceeding. In both situations, the attainment of these favorable outcomes is only possible if the defendant adopts cooperative behavior during the proceeding, dialoguing with law enforcement authorities and waiving traditional proce-

905 As noted by Klaus Malek: Malek, 'Abschied von Der Wahrheitssuche' (n 470) 561. Florian Jeßberger observes that both the crown-witness regulation and the system of negotiated judgments open new possibilities for procedural participants, increasing their room for maneuvers in criminal procedure, see: Jeßberger, Kooperation Und Strafzumessung: Der Kronzeuge Im Deutschen Und Amerikanischen Strafrecht (n 1) 140-143. For a detailed analysis of the relationship between the two legal mechanisms, see: Kerstin Labs, Die Strafrechtliche Kronzeugenregelung - Legitimation Einer Rechtlichen Grauzone? (Tectum Wissenschaftsverlag 2016) 69-79.

906 See item I.2.d.

907 Frahm (n 482) 128. 
dural rights, such as the right to silence. ${ }^{908}$ The two legal regulations design positive incentives for accused to confess to the conduct under investigation, drawing a clear distinction between defenders willing to adopt cooperative behavior, who therefore may benefit from penalty reductions, and offenders who remain in the traditional defensive position, and will be prosecuted and tried according to conventional criteria, without obtaining any advantages. ${ }^{909}$

Although the provisions are similar in this regard, a more detailed analysis also reveals great differences between them. A main difference concerns the nature of the exchange that justifies the granting of benefits to confessed offenders. In the crown-witness regulation, the favorable treatment stems from the defendant's capacity to cooperate with the authorities in clarifying facts regarding crimes committed by others. ${ }^{910}$ The benefits granted to the defendant are directly related to the significance of the cooperation in the investigation and prevention of crimes committed by other individuals, who would likely otherwise remain unpunished. ${ }^{111}$ The cooperative behavior of the defendant is not restricted to his own acts, and must necessarily include offenses committed by third parties. ${ }^{912}$ The cooperating defendant provides law enforcement authorities with information and evidence on crimes that do not coincide with the acts performed by himself.913

908 Regarding the crown-witness regulation, Florian Jeßberger asserts that the differentiated treatment between cooperative and non-cooperative defendants is the "motor" of the legal mechanism. See: Jeßberger, 'Nulla Poena Quamvis in Culpa: Ammerkungen Zur Kronzeugenregelung in \$46StGB' (n 2) 1161.

909 The alleged incompatibility of the crown-witness regulation with the constitutional principle of equal treatment has often been cited as a major obstacle to the development of the crown-witness regulation in German criminal law. See: Christoph (n 1) 159-172. In the practice of negotiated judgments, the problems of inequality arise particularly in the issue of the so-called sanctioning scissors ("Sanktionsschere"), which create a wide gap between the punishment imposed on cooperative and non-cooperative defendants. For an empirical assessment of this practice, see: Altenhain, Dietmeier and May (n 679) 178-190.

910 Tobias Mushoff notes that the crown-witness regulation "may only constitute a legitimate instrument of criminal prosecution when it can contribute to the determination of truth”. See: Tobias Mushoff, 'Die Renaissance Der Kronzeugenregelung' (2007) 90 Kritische Vierteljahresschrift für Gesetzgebung und Rechtswissenschaft 366, 370.

911 Jeßberger, 'Nulla Poena Quamvis in Culpa: Ammerkungen Zur Kronzeugenregelung in $₫ 46 \mathrm{StGB}$ ' (n 2) 1159.

912 As expressly provided for in the German Criminal Code $(S t G B)$, $\$ 46 \mathrm{~b} 3$.

913 Mehrens (n 11) 29. 
This scenario is completely different from the legal framework of negotiated judgements established in $\$ 257 \mathrm{c}$ StPO, which provides for consensual arrangements based essentially on the granting of a penalty reduction in exchange for a confession by the defendant that accelerates the criminal proceeding, ${ }^{914}$ a transaction that does not directly affect other accused. In the crown witness regulation of $\$ 46 \mathrm{~b}$ StGB, the accused's confession does not suffice to justify the granting of legal benefits, which can only be conferred if the accused effectively contributes to the prosecution of crimes committed by third parties. ${ }^{915}$

While the negotiation provided in $\$ 257$ c StPO occurs through quite simple exchanges, the use of the crown witness-regulation is more complex, since it always involves other accused. In the crown-witness regulation, the reduction of the cooperator's penalties must be accompanied by concrete results in the investigation against third parties, in order to generate an overall positive effect from the point of view of the state's prosecution capacity. ${ }^{916}$ The granting of benefits represents a deviation from the correct punishment applicable to the cooperating defendant, and this situation can only be justified if compensated by an increase in the state's capacity to prosecute other offenders. ${ }^{917}$ Thus, unlike the negotiated judgments provided in $\$ 257 \mathrm{c}$ StPO, the exchange between public authorities and defendants foreseen in the crown-witness regulation cannot be performed when there is no third party to be investigated.

The differences between the two regulations are also clear in the objectives sought by each one. In the 2005 decision that requested the German legislature to regulate the practice of informal negotiated judgments, the Federal Court of Justice argued that, given the shortage of resources, the German criminal justice system could not respond to the current demand in a socially acceptable manner through traditional criminal proceed-

914 Luis Greco notes that the primary goal of the granting of benefits under the framework of $\$ 257 \mathrm{c}$ StPO is to allow for the abbreviation of the criminal process. See: Greco, „Fortgeleiteter Schmerz“ - Überlegungen zum Verhältnis von Prozessabsprache, Wahrheitsermittlung und Prozessstruktur' (n 26) 5. Klaus Malek observers that the exchange of a confession for a penalty reduction in the penalty is an essential part of the framework of negotiated judgments. See: Malek (n 470) 565.

915 Buzari (n 12) 55.

916 Jeßberger (n 1) 102-103.

917 Hoyer (n 442) 236. 
ings. ${ }^{918}$ According to the decision, should negotiated judgments be forbidden, the proper functioning of the German judicial system would be seriously compromised and lead to a situation incompatible with the principles of procedural economy ("Grundsatzes der Prozeßökonomie") and celerity ("Beschleunigungsgrundsatz"), which require the existence of procedural mechanisms for the timely rendering of judgments. ${ }^{919}$

The need to save the resources of the justice system through faster proceedings was expressly accepted as one of the bases of the bill that led to the regulation of the practice of negotiated judgments. ${ }^{920}$ This reasoning is in accordance with the main line of defense of consensual solutions in German criminal law, which perceives procedural economy and celerity, in a context of resource scarcity, as the core values embodied by the practice of negotiated judgments. ${ }^{921}$

These goals are clearly very different from those sought by the crownwitness regulation, which main function is to enable public authorities to discover facts and obtain evidence in specific areas, such as terrorism, organized crime and economic criminality, where traditional investigative tools are ineffective. ${ }^{922}$ The objective of the crown-witness regulation is not to save the resources of the judicial system or to accelerate the resolution of criminal cases, but rather to increase the state's capacity to investigate, prosecute and punish sophisticated and hermetic criminal structures. ${ }^{923}$

A third difference between the regulations established by $\$ 257 \mathrm{c}$ StPO and by $\mathbb{S} 46 \mathrm{~b}$ StGB concerns their impact on criminal procedure. In the framework of negotiated judgments set by $\$ 257$ c StPO, consensual arrangements between procedural participants lead to the shortening of the

918 See BGH, Beschl. v. 3.3.2005 - GSSt 1/04 = BGHSt 50, 40, para 49-50. For more details of the decision, see item IV.2.c.

919 ibid para 50-51. Regarding the importance of the principle of celerity ("Beschleunigungsgrundsatz"), see Heger and Kuterrer-Lang (n 694) 76-79.

920 See Deutscher Bundestag, 'BT-Drucksache 16/12310' (18 March 2009), 7.

921 As Julia Peters observes, the defense of the practice of negotiated judgments in Germany has been made primarily on the grounds of procedural economy. See: Peters (n 680) 17. Several authors question whether the goal of the practice of agreements in the German legal system was to overcome the lack of resources of the Judiciary. In this regard, see Malek, 'Abschied von der Wahrheitssuche' (n 470) 565 .

922 As can be seen from the bill that introduced the crown-witness regulation. See Deutscher Bundestag, 'BT-Drucksache 16/6268' (24 August 2007), 1.

923 ibid 9. 
phase of fact-finding and gathering of evidence. ${ }^{924}$ The conclusion of an agreement allows the outcome of the investigation to be influenced, to a greater or lesser extent, by an agreement between the parties. The defendant's confession brings an important element of legitimacy for the imposition of criminal punishment, ${ }^{925}$ allowing for a reduction of the investigative efforts carried out in the official investigation. On the other hand, the use of the crown-witness regulation expands, rather than abbreviates, the fact-finding phase. The main activity of the cooperator is to provide authorities with new information and evidence relevant to the criminal prosecution of other individuals. If the offender lacks the capacity to broaden the body of evidence, there is no legal basis for drawing on the crown-witness regulation. ${ }^{926}$

ii. Consent and search for truth: different answers to similar questions? Disenchantment and re-enchantment with truth-finding in criminal procedure

The framework of negotiated judgments set by $\$ 257$ c StPO and the general crown-witness regulation introduced by $\$ 46 \mathrm{~b} S \mathrm{tGB}$ expand the field of action of procedural participants and confer benefits for defendants who confess to the investigated acts and adopt a cooperative attitude. Despite these similarities, the two provisions are clearly different regarding the purposes they fulfill in the enforcement system, the impacts they have on criminal proceedings and the nature of the exchanges they create between public authorities and confessed offenders.

In fact, the two regulations can be perceived as different - and, in a sense, opposite - manners of dealing with new challenges faced by the German criminal justice system from the late twentieth century, particularly in relation to the appearance of new forms of criminal structures in society and the establishment, in substantive criminal law, of new types of criminal offenses. ${ }^{927}$

924 Greco, „Fortgeleiteter Schmerz“ - Überlegungen Zum Verhältnis von Prozessabsprache, Wahrheitsermittlung Und Prozessstruktur' (n 26) 5.

925 As noted critically by Hassemer, 'Konsens Im Strafprozeß' (n 698) 180.

926 Christoph (n 1) 100-101.

927 Bernd Schünemann notes that a large part of the recent developments in German criminal procedure represent reactions to changes in society and in German criminal law. The author speaks of a "modernization of criminal procedure" caused by the "modernization of the structures of anomalous behavior". 
The practice of informal agreements was initiated in the late 1970s, in the context of large and complex criminal investigations, mainly in the prosecution of white-collar crimes and drug trafficking. ${ }^{928}$ The increasing demand for the services of the criminal justice system, especially in proceedings requiring enormous investigative efforts, created a situation with high incentives for the use of consensual solutions that shortened the official inquiry. ${ }^{929}$ The evidentiary complexities and the extended length of the so-called "monster proceedings" ("Monster-Verfahren") put an enormous burden on both the judicial bodies and defendants. ${ }^{930}$ Given the extravagant costs associated with this type of investigation and the difficulties in distinguishing regular activities from criminal behavior, the development of negotiated judgments, which deliver a secure outcome and spare resources, appeared as a practical solution for all the involved parties.

The crown-witness regulation, on the other hand, appears not as a mechanism of process management in a scenario of resource scarcity, but rather as a fact-finding tool that allows law enforcement authorities to expand investigations into conducts perpetrated by sophisticated and hermetic structures. ${ }^{931}$ In order to obtain the benefits provided by the crown-witness regulation, the defendant must present new evidence regarding acts committed by other individuals. ${ }^{932}$ The granting of favorable treatment is directly related to the defendant's capacity to assist law enforcement authorities in overcoming situations of "investigative emergencies", characterized by the elevated cost of evidence collection and the high damages arising from criminal behavior. ${ }^{933}$ The defendant's confession is not sufficient to guarantee obtainment of the benefits, which will only be granted if the material provided leads to effective prosecution of specific crimes committed by identifiable individuals. ${ }^{934}$

See: Schünemann, 'Die Zukunft Des Strafverfahrens - Abschied Vom Rechtsstaat?' (n 695) 947.

928 Altenhain, Dietmeier and May (n 38) 20.

929 Weigend, 'Abgesprochene Gerechtigkeit - Effizienz Durch Kooperation Im Strafverfahren?' (n 670) 775.

930 Bernd Schünemann, 'Zur Kritik des amerikanischen Strafprozessmodells' (n 25) 570-571.

931 Affirming that the legitimacy of the crown-witness regulations arises from its capacity to ascertain the truth, see Mushoff (n 910) 370.

932 Buzari (n 12) 55.

933 Jeßberger, Kooperation Und Strafzumessung: Der Kronzenge Im Deutschen Und Amerikanischen Strafrecht (n 1) 304.

934 Malek (n 481) 201. 
In view of the evidentiary challenges to the establishment of criminal liability in complex investigations, both the statutory framework of negotiated judgments ( $\$ 257 \mathrm{c}$ StPO) and the general crown-witness regulation $(\$ 46 \mathrm{~b}$ StGB $)$ design procedural solutions based on exchanges between defendants and law enforcement authorities. However, while a negotiated judgment means the interruption or reduction of the fact-finding process, in the crown-witness regulation the exchange implies an expansion of the efforts to determine the relevant facts and collect evidence. While the practice of negotiated judgments emerged due to the complexities of "monster proceedings" and in a context of "disenchantment" with the idea of searching for truth, ${ }^{935}$ the crown-witness regulation reinforces the state's commitment to apply criminal law through a thorough inquiry, in what may be seen as "re-enchantment" with the notion of truth-finding in complex investigations.

This fundamental difference between the framework of negotiated judgments and the crown-witness regulation in German law has clear practical implications. The legislative proposals that led to the introduction of $\$ 257 \mathrm{c}$ StPO and 46b StGB in 2009 placed much emphasis on the necessary differentiation between the two legal institutions. ${ }^{936}$ According to the legislative debates, the main function of the crown-witness regulation was to clarify and prevent serious criminal conduct and it should not be transformed into a form of negotiated judgment. ${ }^{937}$ To establish a strong limit between the framework of negotiated judgments and the crown-witness regulation, the German legislature designed a temporal restriction:938 while the crown-witness regulation can be used only before the beginning of the formal criminal proceeding, a negotiated judgment can be achieved

935 According to Bernd Schunemann, "both the modern findings of social sciences and the practical experiences with monster proceedings led to the disenchantment with the objective of criminal procedure as searching the substantive truth through the main hearing (...)". See: Schünemann, 'Die Verständigung Im Strafprozeß - Wunderwaffe Oder Bankrotterklärung Der Verteidigung?' (n 27) 1898.

936 Frahm (n 482) 128.

937 See the legislative debates that preceded the enactment of the general crownwitness regulation: Deutscher Bundestag, 'BT-Drucksache 16/13094' (20 May 2009), 5.

938 Buzari (n 12) 89. 
only after this moment. ${ }^{939}$ This rule of the general crown-witness regulation prevents an overlap with the framework of negotiated judgments. ${ }^{940}$

At this point, a plain contrast between the U.S. and the German experiences with cooperating defendants becomes clear: while in the U.S. system the granting of benefits to cooperators is a common aspect of the wide discretionary powers granted to prosecutors, in Germany the crown-witness regulation appears as a momentary departure from traditional principles of criminal procedure in situations of investigative emergencies. ${ }^{941}$ In the American party-driven system, cooperation agreements are part of a wide range of consensual arrangements that can be freely negotiated, ${ }^{942}$ leading to a situation where partnerships between defendants and law enforcement authorities to prosecute other individuals are recurrent in several types of investigation. ${ }^{943}$ In Germany, the use of cooperating defendants can occur only in a very narrow manner and under strict conditions: for the granting of benefits to cooperating defendants to become the rule instead of the exception, the criminal justice system would have to be fully restructured on a completely different basis. ${ }^{944}$ Whereas in the U.S. both the system of plea bargaining and the granting of benefits to cooperating defendants are by-products of a structure of criminal procedure that confers near-total control of criminal cases to the parties, the framework of ne-

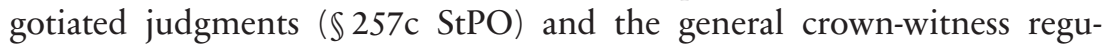
lation $(\$ 46 \mathrm{~b} \mathrm{StGB}$ ) have different foundations and fulfill diverse functions within the German justice system.

939 As provided in the German Criminal Code $(S t G B)$, $\$ 46 \mathrm{~b}$ para 3, and in the Ger-

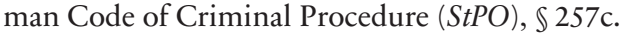

940 Kneba (n 861) 162.

941 Jeßberger, Kooperation Und Strafzumessung: Der Kronzeuge Im Deutschen Und Amerikanischen Strafrecht (n 1) 304.

942 Jaeger (n 3) 266.

943 On the widespread use of cooperating defendants in the American criminal justice, see Weinstein (n 3) 564-565.

944 Jung (n 442) 40. 
b. Expansion of the negotiation forum, externalities and abstinence from the search for truth

i. The tension over the boundaries of the room for negotiation and the troublesome taming of negotiated judgments

The German experience with the practice of negotiated judgments is marked by attempts - both repeated and unsuccessful - to regulate the negotiation practices developed by legal practitioners. After the unveiling of the widespread use of informal agreements, German higher courts sought to "tame" the negotiations between parties through decisions that, while refusing to declare the practice completely illegal, imposed a series of limits to guarantee that the agreements were in accordance with the principles of the German legal system..$^{945}$ This position can be found in the ruling of the German Constitutional Court of $1987^{946}$ and in the judgments of the Federal Court of Justice of $1997^{947}$ and 2005, ${ }^{948}$ which affirmed the need for consensual solutions to respect the state's commitment to search for truth and the principles of culpability, due process and transparency. ${ }^{949}$ Legal practitioners, however, refused to acknowledge the boundaries defined by these judicial decisions and continued to conclude agreements without taking into account the requirements imposed by the courts. 950

The legislative regulation introduced in 2009 sought to rescue the practice of negotiated judgments from an environment of complete informality, inserting into the German Code of Criminal Procedure (StPO) a statutory framework with requirements and restrictions very similar to those defined by the Federal Court of Justice in its 2005 ruling. ${ }^{951}$ The introduction of $\$ 257 \mathrm{c}$ StPO was based on the expectation that, faced with clear statutory rules, legal practitioners would restrict their transactions to the

945 Claus Roxin and Bernd Schunemann, Strafverfahrensrecht: Ein Studienbuch (C.H. Beck 2017) 100.

946 See BVerfG, Beschl. v. 27.1.1987 - 2 BvR 1133/86 = NJW 1987, 2662.

947 See BGH, Urt. v. 28.8.1997 - 4 StR 240/97 = BGHSt 43, 195.

948 See BGH, Beschl. v. 3.3.2005 - GSSt 1/04 = BGHSt 50, 40.

949 On the judicial acknowledgment of the practice of negotiated judgments, see item IV.2.c.

950 For a comprehensive analysis of the matter, see: Altenhain, Dietmeier and May (n 38).

951 König classifies the regulation as an attempt of "taming the negotiated judgments" ("Bändigung der Verständigung”). See: König and Fassung (n 820) 114. 
boundaries defined by the legislature and by the traditional principles of the German legal system. This expectation proved to be ill-founded, and the situation of flagrant disregard for the limits imposed on the bargaining practices remained unchanged. ${ }^{952}$

The most recent attempt at taming the use of consensual solutions in the German criminal justice system occurred in the 2013 decision of the Constitutional Court, which examined the constitutionality of $\$ 257 \mathrm{c} \mathrm{StPO} .^{953}$ In its ruling, the Court, confronted with the fact that the practice of informal negotiated judgments was widespread and deeply entrenched in the German judiciary, basically reaffirmed the need for procedural participants to comply with the legal standards established by the Code of Criminal Procedure. ${ }^{954}$

The German experience demonstrates that, in the pursuit of a swift and satisfactory end to criminal proceedings, procedural participants tend to continually expand the space for negotiation beyond the statutory boundaries. Particularly in situations where the outcome of the investigation is uncertain and the process of fact-finding and collection of evidence is costly, as in cases of "monster proceedings" in the field of white-collar criminality, all legal practitioners - defendants, prosecutors and judges - have incentives to find a consensual solution that saves resources and leads to fast and secure outcomes.

In this context, the introduction of a legitimate and restricted room for negotiation tends to represent a "gateway drug" ("Einstiegsdroge") for legal practitioners, ${ }^{955}$ who are increasingly inclined to use this communication channel to solve the judicial day-to-day problems in a consensual manner. The establishment of a legitimate room for negotiation in the criminal justice system allows the procedural parties to communicate with each other in order to reach possible agreements that meet their interests. Over time, the reiterated interactions between legal practitioners and the development of trust-based relationships enable the design of new and unexpected forms of consensual arrangement, pushing the boundaries of the negotiation forum established by the statutory regulation.

952 See: Altenhain, Dietmeier and May (n 38).

953 See BVerfG, Urt. v. 19.3.2013 - 2 BvR 2628/10 u.a. = BVerfGE 133, 168.

954 See item IV.2.e.

955 Martin Heger and Robert Pest note that section $\$ 153 \mathrm{a}$ StPO, which established possibilities for inter-parties negotiations in cases of minor offenses, is frequently depicted as a 'gateway drug' ("Einstiegsdroge") for the development of informal negotiated judgments. See: Heger and Pest (n 37) 449. 
In the German practice of negotiated judgments, the parties not only negotiated arrangements that are openly contrary to the 2009 legislative regulation, such as agreements that waved the right to appeal and defined the exact sentence to be imposed on the defendant. ${ }^{956}$ They also designed increasingly comprehensive and sophisticated solutions, which include a wide range of clauses that have no relation to the statutory rules. An empirical study carried out in 2012 at the request of the German Constitutional Court revealed a variety of examples, such as agreements dealing with the immigration status of the accused. .57

A point that draws attention is the conclusion of an agreement, in a criminal proceeding, that also affects other investigations. This type of negotiation - known as "package deal" ("Gesamtlösungen") - was developed as a way to reduce the parties' costs in resolving interconnected cases, especially in the fields of corporate and economic crime. ${ }^{958}$ In some situations, agreements not only resolved other charges faced by the accused, but also ended investigations into conduct attributed to third parties, usually relatives of the accused. In one case, the defendant agreed to serve a higher sentence in exchange for the granting of parole to his wife so that she could take care of their children at home. ${ }^{959}$

ii. Negative externalities and abstinence from the search for truth

The introduction of negotiation forums into the criminal justice systems of Continental tradition countries engenders a hard-to-solve contradiction between the objectives sought by the legislator and the daily reality of the procedural parties. From the legislator's perspective, the permission for certain types of agreement is deemed a necessary response to the practical demands and the limited resources of the judicial system. ${ }^{960}$ Nevertheless, given the state's commitment to the search for truth and to the protection

956 The 2009 legislative regulation expressly forbade parties from defining the exact punishment and from dispensing with the right of appeal. As noted by the 2013 ruling of the German Constitutional Court, these rules were often circumvented by legal practitioners. See BVerfG, Urt. v. 19.3.2013 - 2 BvR 2628/10 u.a. = BVerfGE 133, 168, para 48-49, 73-74 and 94-95.

957 Altenhain, Dietmeier and May (n 38) 77-78.

958 Schemmel, Corell and Richter (n 671) 63.

959 See BVerfG, Urt. v. 19.3.2013 - 2 BvR 2628/10 u.a. = BVerfGE 133, 168, para 49.

960 See the justification of the proposal that introduced the legislative regulation of negotiated judgments: Deutscher Bundestag, 'BT-Drucksache 16/12310' (18 
of other values enshrined in criminal law, the validity of consensual arrangements is conditioned to a range of statutory requirements that limit the parties' capacity to dispose of criminal cases. In this context, the statutory rules appear as fixed boundaries that the procedural actors must strictly comply with, under penalty of violating several principles of criminal procedure law. ${ }^{961}$

In day-to-day judicial practice, by contrast, procedural participants have incentives to constantly expand the limits of the forum for negotiations, in an attempt to achieve satisfactory outcomes and spare resources. The design of a legitimate sphere of communication and the development of bonds of trust between practitioners allow the design of new forms of consensual arrangements not foreseen by the legislator. The legislative regulation, intended to be a ceiling for the possibilities of agreements, becomes the ground level for the construction of increasingly bold and innovative solutions, with widespread effects on the justice system.

A clear consequence of this development is the reduction of the state's commitment to assessing the guilt of the defendant through a comprehensive investigation of the suspicious conduct. ${ }^{962}$ Consensual mechanisms enable the replacement of the long and costly fact-finding process with an agreement that quickly defines the outcome of a criminal case, which comes with the accused's consent and, therefore, with an apparent aura of legitimacy. ${ }^{963}$

By allowing procedural participants to negotiate over the outcome of criminal proceedings, consensual mechanisms entail the risk that the official investigation will be prematurely terminated and that a guilty verdict will arise from an inter-party arrangement, rather than from the collection

March 2009), 7-8. Julia Peters notes that the main argument for the development of negotiated judgments in Germany is the scarcity of resources. See Peters (n 680) 17. Similarly, Mirjan Damaska observes: "In the end, practical usefulness or necessity turns out to be the only persuasive justification for negotiated justice”. See Damaška (n 668) 1030.

961 As affirmed by the German Constitutional Court in its 2009 ruling on the constitutionality of the regulation of negotiated judgments. See BVerfG, Urt. v. 19.3.2013 - 2 BvR 2628/10 u.a. = BVerfGE 133, 168, para 65-75.

962 Tatjana Hornle, 'Unterschiede Zwischen Strafverfahrensordnungen Und Ihre Kulturellen Hintergründe' (2006) 117 Zeitschrift für die Gesamte Strafrechtswissenschaft 801.

963 As Winfried Hassemer observes, the accused's acceptance of the outcome of the criminal proceeding brings a valuable element of legitimation for the exercise of the state's power. See: Hassemer (n 699) 180. 
of hard evidence proving criminal behavior. ${ }^{964}$ Given that criminal convictions generate harsh consequences for the whole society, the requirement for criminal punishment to have a strong factual basis is relevant not only for the guarantee of the defendant's rights, but also for the protection of various other interests protected by criminal law. ${ }^{965}$ The consensual resolution of criminal cases generates several collateral effects that impairs the interests of other agents who do not take part in in the negotiations. ${ }^{966}$

Interested in minimizing the risks and costs imposed by a criminal investigations, procedural participants have incentives to constantly expand the negotiation forum designed by the legislation. As with transactions that create negative externalities, the parties that enter into consensual arrangements in criminal cases do not assume all the costs arising from such negotiations, leading to a permanent tension on the limits defined by law. ${ }^{967}$ This expansionist movement poses serious risks for traditional values inherent to the Continental tradition, particularly to the state's commitment to search for truth through criminal proceedings. ${ }^{968}$

The imposition of criminal punishment embodies the public message that the accused has willingly adopted wrongful behavior; the legitimacy of this message depends on the collection of solid evidence of the crime, and not on the consent of the accused. ${ }^{969}$ The preservation of the public interest and the very legitimacy of the criminal justice system rely, thus, on the execution of a thorough investigation to ascertain the offenses and the responsible individuals. ${ }^{970}$ In the long run, the spreading and proliferation of increasingly innovative and sophisticated consensual solutions may lead

964 As Greco notes, the restriction of the fact-finding phase is the main reason why the judicial system adopts the Verstandigung mechanism. Greco, '"Fortgeleiteter Schmerz" - Überlegungen zum Verhältnis von Prozessabsprache, Wahrheitsermittlung und Prozessstruktur' (n 26) 5.

965 Weigend, 'Unverzichtbares Im Strafverfahrensrecht' (n 23) 304; Schünemann, 'Zur Kritik Des Amerikanischen Strafprozessmodells' (n 25) 557-562.

966 Greco, Strafprozesstheorie Und Materielle Rechtskraf (n 668) 277-278.

967 Mirjan Damaska notes that "It is indeed unlikely that the parties will take into account the full cost that their transaction imposes on others with whom they have no immediate relationship". See: Damaška (n 668)1028.

968 Wesslau (n 25) 563-564.

969 Greco, Strafprozesstheorie Und Materielle Rechtskraf (n 668) 273-274.

970 Schünemann, 'Zur Kritik Des Amerikanischen Strafprozessmodells' (n 25) 559; Weigend, 'Unverzichtbares Im Strafverfahrensrecht' (n 23) 304. 
to a model of "systematic abstinence" from the state's task of truth-searching, with deep repercussions throughout the legal system. ${ }^{971}$

iii. The 2013 ruling of the German Federal Constitutional Court and the case-law of the U.S. Supreme Court: unnoticed virtues?

Confronted with the problem of defining the limits for consensual solutions within the criminal justice system, the German Constitutional Court sought an intricate balance between the traditional pillars of Continental criminal procedure, such as the state's commitment to search for truth, the principle of individual culpability and the rules of publicity, formal documentation and transparency, and the entrenched practice of negotiated judgments in the German judiciary. In view of a scenario of massive and widespread disregard for the statutory framework set by $\$ 257 \mathrm{c}$ StPO, the Court decided to not rule the legislative regulation of negotiated judgments unconstitutional, opting instead to harshly censure the routines used by legal practitioners to resolve criminal cases through innovative consensual arrangements. ${ }^{972}$

The decision was harshly criticized from different sides of the debate. ${ }^{973}$ From the legal practitioners' point of view, the ruling created excessive burdens and uncertainties for the conclusion of consensual arrangements and could end up rendering them useless. ${ }^{974}$ For critics, the decision was another lost chance to develop effective control over the practice of negoti-

971 As noted by Hassemer regarding the proliferation of consensual solutions in German criminal justice . See: Winfried Hassemer, ' Human dignity in the criminal process: the example of truth-finding' (2011) 44 Israel Law Review 185, 198.

972 See BVerfG, Urt. v. 19.3.2013 - 2 BvR 2628/10 u.a. = BVerfGE 133, 168, para 116-127.

973 As noted by Rabe: Rabe (n 714) 35-36.

974 According to Schemmel: "The increased demands of evidence collection and the lack of a binding effect of "package deals" therefore significantly complicate the settlement process in commercial criminal law. The significantly-tightened situation can therefore hardly be overcome without multiplying judicial resources because, from a judicial perspective, a settlement is almost useless if the time required is not significantly reduced because the disputable procedures have the same requirements for clarification”. See: Schemmel, Corell and Richter (n 671) 63. 
ated judgments and reconcile it with the requirements of the German Constitution. ${ }^{975}$

Such reactions were to be expected, given the fragility of the balance sought by the German Federal Constitutional Court. As Luis Greco points out, the ruling leads to an insoluble trilemma: if the matter of the confession is not verified throughout the proceeding, the objective of procedural shortening is accomplished, but the constitutional guarantees that the Constitutional Court tried to safeguard will remain unprotected; if the confession has to be proven in a full discovery phase, the negotiated judgments lose their function; if the option is for an intermediate path, in which a partial verification of the confession is carried out, there are no criteria that minimally indicate in what level of depth this verification should occur. ${ }^{976}$

Despite the clear limits and gaps of the decision, the firm rebuff of "a new consensual procedural model" should not be underestimated. ${ }^{977} \mathrm{Al}-$ though recognizing the relevance of negotiated judgments within the German justice system, the German Federal Constitutional Court imposed constraints upon the consensual resolution of criminal cases and expressly prohibited consensual innovations such as the so-called "package deals". ${ }^{978}$ The decision criticized the possibility of a "commerce of justice" and affirmed the importance of a serious fact-finding process in criminal procedure, refusing to recognize that criminal convictions could stem merely from consensual arrangements between procedural parties. ${ }^{979}$

This position stands in clear contrast with the treatment given by the U.S. Supreme Court to the questions arisen from the exponential growth of plea bargaining in the last decades of the 20th century. In a series of decisions rendered in the 1970s, the U.S. Supreme Court supported this development, perceiving that plea agreements could benefit all the affected: defendants would benefit from the swift processing of their cases and the

975 See: Weigend, 'Neues Zur Verständigung Im Deutschen Strafverfahren?’ (n 37) 217-219.

976 Greco, ‘„Fortgeleiteter Schmerz“ - Überlegungen Zum Verhältnis von Prozessabsprache, Wahrheitsermittlung Und Prozessstruktur' (n 26) 5.

977 Regarding this rejection, see BVerfG, Urt. v. 19.3.2013 - 2 BvR 2628/10 u.a. = BVerfGE 133, 168, para 65-67. Praising this part of the decision, see Heger and Pest (n 37) 450. Also Greco, '„Fortgeleiteter Schmerz“' (n 26) 11.

978 See BVerfG, Urt. v. 19.3.2013 - 2 BvR 2628/10 u.a. = BVerfGE 133, 168, para 79.

979 See BVerfG, Urt. v. 19.3.2013 - 2 BvR 2628/10 u.a. = BVerfGE 133, 168, para 129-130. Praising this position, see Weigend, 'Neues Zur Verständigung Im Deutschen Strafverfahren?' (n 37) 214-215. 
possibility of faster rehabilitation, prosecutors and judges would save their scarce resources and society would be better protected. ${ }^{980}$ Faced with evermore audacious consensual arrangements in criminal proceedings, the U.S. Supreme Court chose to accept the expansion of plea bargaining and restricted judicial control of these negotiations to procedural guarantees regarding the expression of the defendant's will. ${ }^{981}$

In a decision of paramount importance, the Supreme Court asserted that plea agreements are valid whenever the defendant has had "full opportunity to assess the advantages and disadvantages of a trial as compared with those attending a plea of guilty", even if the agreement had been carried out to avoid the death penalty. ${ }^{982}$ On another occasion, the Supreme Court affirmed that prosecutors can make threats as a way to induce the investigated to accept the agreement and that, if the agreement is not concluded, such threats can be fulfilled, recognizing as "constitutionally legitimate the simple reality that the prosecutor's interest at the bargaining table is to persuade the defendant to forgo his right to plead not guilty." 983 In another case, the Supreme Court decided that problems of racial discrimination in the jury's composition do not affect the validity of a plea agreement since, after formally pleading guilty, the defendant could not "raise independent claims relating to the deprivation of constitutional rights that occurred prior to the entry of the guilty plea." 984

980 See the ruling of the Supreme Court in Blackledge v. Allison, 431 U.S. 63 (1977): "Whatever might be the situation in an ideal world, the fact is that the guilty plea and the often concomitant plea bargain are important components of this country's criminal justice system. Properly administered, they can benefit all concerned". For a substantiated criticism of this Supreme Court ruling, see: Malvina Halberstam, 'Towards Neutral Principles in the Administration of Criminal Justice: A Critique of Supreme Court Decisions Sanctioning the Plea Bargaining Process' (1982) 73 Journal of Criminal Law and Criminology 1. According to the author: "The Court's decisions in this area contravene fundamental principles of constitutional law and are inconsistent with its decisions in cases that do not involve the viability of the plea bargaining process." (3).

981 As noted by Donald Gifford: "Because the legitimacy of plea bargaining supposedly rests on its consensual nature, under the traditional view the only required regulation of plea bargaining is procedural safeguards designed to assure that the defendant's consent to his guilty plea is legally effective". See: Donald G Gifford, 'Meaningful Reform of a Plea Bargaining: The Control of Prosecutorial Discretion' (1983) 1983 University of Illinois Law Review 37, 39.

982 See Brady v. United States, 397 U.S. 742 (1970).

983 See Bordenkircher v. Hayes, 434 U.S. 357 (1978).

984 See Tollett v. Henderson, 411 U.S. 258 (1973). 
Understanding plea agreements as the embodiment of values such as autonomy and efficiency, the U.S. Supreme Court granted solid support to the practice of bargaining in criminal justice and opted to ignore the various risks associated with new forms of transactions, some of which did not even rely on a guilty plea. ${ }^{985}$ Confronted with the constant innovations brought up by the indomitable practice of negotiated judgments, the German Federal Constitutional Court chose a different path: in its 2013 decision, the Court reaffirmed the state's commitment to the search for truth, the principle of individual culpability and due process as constitutional foundations of the German prosecution system. ${ }^{986}$ To assure the observance of these principles, the German Constitutional Court imposed multiple restrictions on the practice developed by legal practitioners and even threatened to rule the regulation of negotiated judgments unconstitutional, should the pattern of wide disregard for the statutory rules continue. ${ }^{987}$

Given the attractiveness of consensual arrangements to legal practitioners, this firm defense of traditional values of criminal procedure cannot be undervalued, regardless of how naive and formalistic the imposed restrictions may seem. ${ }^{988}$ This is particularly true when one faces the possibility

985 From a German perspective, Luis Greco notes the enormous legitimizing force acquired by consensual exchanges in American criminal justice, validating agreements that do not even contain a confession by the defendant (the socalled "Alford plea"). See: Greco, Strafprozesstheorie Und Materielle Rechtskraft (n 668) 266. The term "Alford plea" comes from the ruling of the U.S. Supreme Court in North Carolina v. Alford, in which the Court decided that "accused may voluntarily, knowingly, and understandingly consent to the imposition of a prison sentence even though he is unwilling to admit participation in the crime." See North Carolina v. Alford, 400 U.S. 25 (1970). In the occasion, the Court reaffirmed the understanding that: "[r]easons other than the fact that he is guilty may induce a defendant to so plead, [and] [h]e must be permitted to judge for himself in this respect". For a strong criticism of this type of consensual arrangement, see: Bibas (n 179) 1363. According to the author, "Alford and nolo contendere pleas are unwise and should be abolished. These procedures may be constitutional and efficient, but they undermine key values served by admissions of guilt in open court."

986 For a general description of the ruling, see item IV.2.e.

987 See BVerfG, Urt. v. 19.3.2013 - 2 BvR 2628/10 u.a. = BVerfGE 133, 168, para 121.

988 On this point, Thomas Weigend asserts that the 2013 German Federal Supreme Court tried hard "to verify the bottle, the label and the cork" but did not recognize that the bottle contained a drink in a terrible state. See: Weigend, 'Neues Zur Verständigung Im Deutschen Strafverfahren?' (n 37) 218. Also expressing doubts on the effectiveness of the solution given by the German Federal Constitutional Court. See: Heger and Pest (n 37) 486. 
of a full endorsement of consensual exchanges as a source of legitimacy for imposition of criminal punishment, as occurred in the 1970s decisions of the U.S. Supreme Court and, more recently, in rulings of the Brazilian Federal Supreme Court regarding the use of collaboration agreements, ${ }^{989}$ as will be analyzed in the next chapter.

\section{Conclusion}

Recently, references to a new model or paradigm of "consensual criminal justice" have abounded in Brazilian criminal law, both in legal scholarship and in judicial decisions. ${ }^{990}$ According to its proponents, this new model of criminal justice would favor the resolution of criminal cases through consensual arrangements negotiated between prosecution and defense, strengthening the autonomy of the parties in the realm of criminal procedure. This ideal of consensual criminal justice has been of paramount importance in justifying and validating the inventive practice of collaboration agreements, which has engendered dramatic innovations over recent years, such as the design of new imprisonment regimes and the possibility of anticipated enforcement of criminal penalties. ${ }^{991}$

Associating collaboration agreements with the traditional concept of private contracts, the Brazilian Federal Supreme Court used doctrines and rules from contractual law - such as the principles of "res inter alios acta" and "pacta sunt servanda" - to interpret and resolve quarrels arising from the use of collaboration agreements. ${ }^{992}$ This "contractualist" approach conferred solid ground and wide freedom for legal practitioners to develop a flexible and comprehensive negotiation system, giving rise to audacious consensual solutions. ${ }^{993}$

In order to analyze the association of the Brazilian practice of collaboration agreements with the concept of a new model of consensual justice, this chapter examined the German experience with two legal mechanisms: negotiated judgments and the crown-witness regulation. After describing the development and main characteristics of both mechanisms, the chapter focused on two points of analysis.

989 For a description of this jurisprudence, see item I.4.c.

990 See item I.4.c.

991 See items I.4.a.

992 See item I.4.c.

993 See item I.4.b. 
It first asserted that, although the two legal mechanisms share some similar features, since both entail consensual elements and design a negotiation forum between enforcement authorities and defendants, they fulfill different roles, seek differing objectives and impact criminal proceedings in a distinct manner. While the practice of negotiated judgments appears as a mechanism of procedural economy in a context of limited resources of the justice system, shortening the process of fact-finding, the crown-witness regulation represents an investigative tool that enhances the state's capacity to collect evidence and information in order to prosecute criminal organizations, expanding the state's efforts to search for truth.

Secondly, observing the standard pattern of widespread disregard shown by the German practice of negotiated judgments towards judicial decisions and statutory rules, it asserted that the use of consensual mechanisms in criminal justice entails negative externalities, creating a permanent tension on the boundaries of the negotiation forum established by law. Because of these externalities, legal practitioners have strong incentives to constantly expand the use of consensual mechanisms, particularly in situations where the process of fact-finding is long, complex and uncertain, as occurs in the field of economic crime. This expansionist movement erodes traditional values and guarantees of German criminal procedure, such as the state's commitment to search for truth, the principle of individual culpability and the rules of publicity, as has been noted by the 2013 ruling of the German Federal Constitutional Court.

From the results achieved in this Chapter IV, as well as the concepts analysed in Chapter III, Chapter V carries out a critical appraisal of the Brazilian practice of collaboration agreements and its alleged association with a new system of consensual criminal justice. 


\section{Chapter V - Truth and consent in collaboration agreements: a rebuff to the contractualist approach}

\section{Introduction}

The enactment of the Organized Crime Act in 2013 represented a major turning point in the role played by consensual arrangements within Brazilian criminal justice. ${ }^{994}$ Until then, negotiations between law enforcement authorities and defendants in criminal investigations were of secondary importance. ${ }^{995}$ The 1995 Small Claims Act introduced possibilities for procedural participants to resolve criminal cases through negotiated transactions, but restricted the use of these mechanisms to investigations of minor offenses. ${ }^{996}$ Apart from that, Brazilian law did not provide other opportunities for consensual arrangements within criminal procedure. Negotiated solutions also did not arise informally in the daily operations and routines of legal practitioners, as occurred in German criminal procedure from the late 1970 s onwards. ${ }^{997}$ This scenario changed completely after the enactment of the Organized Crime Act, which introduced the rewarded collaboration regulation, allowing offenders who committed serious crimes to negotiate and enter into written agreements with law enforcement authorities. Since then, hundreds of collaboration agreements have been concluded, especially in investigations of corruption networks and corporate crimes directly affecting Brazils political and economic elites. ${ }^{998}$

In view of the recent boom in collaboration agreements, several new concerns arose during high-profile investigations, which required courts, including the Brazilian Federal Supreme Court, to quickly respond to fundamental questions regarding the role of consensual arrangements in the

994 Regarding the rapid development of the practice of collaboration agreements since 2013, see items I.2.b. and I.4.

995 On the restricted possibilities for inter-party negotiations within Brazilian criminal procedure, see item I.1.

996 Only minor crimes, punishable with a maximum of two years of imprisonment, can be subject of a consensual solution provided in the 1995 Small Claims Act. See item I.1.

997 On the development of the practice of negotiated judgments in Germany, see section IV.2.

998 See sections II.2 and II.4. 
Brazilian criminal justice system. Which aspects of criminal proceedings can be negotiated between cooperators and law enforcement authorities? How constrained are parties by the statutory provisions of the Organized Crime Act? When can other defendants question in court the legality and the terms of a cooperator's agreement? To what extent are inter-party transactions binding upon judicial bodies? A decision on these issues proved to be of paramount importance, given the development of an inventive model of negotiation in the Brazilian practice of collaboration agreements, which devised a comprehensive and flexible system of arrangements that was plainly detached from the text of the Organized Crime Act.999

Faced with agreements that established audacious consensual innovations, the Brazilian judiciary, following guidelines from the Brazilian Federal Supreme Court, opted to give strong support to the practice of collaboration agreements. ${ }^{1000}$ On numerous occasions, Brazilian courts validated the conclusion of inventive and ingenious collaboration agreements, endorsing the development of a model of negotiation that conferred enormous discretion and freedom upon cooperating defendants and law enforcement authorities.

To that end, two jurisprudential developments were fundamental. The first refers to the understanding that collaboration agreements are bilateral transactions between the state and the cooperator that do not affect the legal interests of third parties. ${ }^{1001}$ From this perspective, courts applied the res inter alios acta doctrine and denied other defendants the right to question in court the legality of a cooperators agreement. The second relates to the position that collaboration agreements have a binding effect upon judicial bodies, who must comply in their sentences with the terms negotiated by the cooperator and law enforcement authorities. ${ }^{1002}$

This chapter rejects this "contractualist" approach to collaboration agreements and the broad model of negotiation developed in the Brazilian practice of the rewarded collaboration regulation. ${ }^{1003}$ It asserts that the contractualist approach misunderstands the function fulfilled by the rewarded collaboration regulation in Brazilian law and seriously undermines basic values protected by the Brazilian system of criminal justice. Further-

999 On the detachment between the textual provisions of the rewarded collaboration regulation and the judicial practice, see item I.4.a and I.4.b.

1000 See section I.4.

1001 See item I.4.c.ii.

1002 See item I.4.c.i.

1003 On the contractualist approach to collaboration agreements, see section I.5. 
more, it argues that the characteristics of the current practice of collaboration agreements also jeopardize the development of a sound leniency policy and may have, from an effectiveness point of view, disturbing side effects.

Section V.2 rejects the use of concepts from private contract law to interpret the rewarded collaboration regulation and highlights the grave risks brought by the consensual innovations that mark the Brazilian practice of collaboration agreements. It also argues that the Brazilian rewarded collaboration represents, in a similar manner to the German crown-witness regulation, an extraordinary tool to overcome situations of investigative emergencies, and not an aspect of the parties' powers to dispose of criminal proceedings. Section V.3 rejects the association of the rewarded collaboration regulation with the concept of consensual justice and repudiates the idea that collaboration agreements integrate a new system of criminal justice, separate from the traditional Brazilian criminal procedure. Instead, it asserts that collaboration agreements must be understood as durable public-private partnerships between public authorities and defendants, leading to a complex process of partial privatization of investigative and prosecutorial functions. Section V.4 rejects the notion that parties may bind judicial sentences through collaboration agreements and highlights the negative externalities that arise from such transactions, asserting the need for strict judicial control to guarantee the regularity, legitimacy and effectiveness of the practice of collaboration agreements.

\section{The practice of collaboration agreements: incompatibility with Brazilian criminal justice and counterproductive effects}

The rewarded collaboration regulation designed a communication forum that enables law enforcement authorities to engage in negotiations with offenders and conclude written agreements in order to obtain their cooperation in the prosecution of former co-conspirators. According to the provisions of the Organized Crime Act, these transactions are quite simple: in return for the cooperator's assistance, courts may grant a judicial pardon, lower the imprisonment penalties by up to two-thirds or replace them with a penalty of restriction of rights. ${ }^{1004}$ In specific circumstances, the

1004 On the benefits provided by the rewarded collaboration regulation, see item I.3.b.i. 
Public Prosecution Office may also drop charges against the cooperator. 1005

The Brazilian practice of collaboration agreements, however, evolved in a very distinctive manner. As a wide array of cases demonstrates, procedural participants used the communication forum to formulate complex consensual arrangements and devise striking innovations not provided for by the Organized Crime Act. Rather than implementing the system of simple transactions designed by the Organized Crime Act, legal practitioners devised intricate and comprehensive consensual arrangements that resembled sophisticated private contracts, meticulously predefining a broad spectrum of issues within criminal proceedings.

A major innovation was the exact definition of imprisonment penalties in early stages of the investigation: instead of outlining the benefits provided by law, collaboration agreements have precisely determined the criminal punishment of the cooperating defendant and detailed how it should be fulfilled. ${ }^{1006}$ Another novelty was the design of "package deals", which defined a "unified penalty" for a wide range of wrongdoings and encompassed multiple criminal proceedings. ${ }^{1007}$ Collaboration agreements also provided several new benefits not foreseen in the rewarded collaboration regulation, such as the design of "differentiated" detention regimes, which allowed cooperators to serve long imprisonment sentences in their private residences with several prerogatives. ${ }^{1008}$ They also contained clauses authorizing cooperating defendants to serve the negotiated imprisonment penalties in advance, before the pronouncement of the judicial verdict and sentence. ${ }^{1009}$

The adoption of a model of tailor-made negotiations led to the development of customized transactions, with every agreement having unique provisions to meet the specific needs of different cooperating defendants. Instead of conforming to the standard provisions of statutory regulation, collaboration agreements formulated a unique set of rights and duties for each case, creating a rich assembly of original clauses and innovative solutions. ${ }^{1010}$

1005 According to the Organized Crime Act, this can occur when the cooperating defendant was not the leader of the criminal organization and was the first to effectively cooperate. See Brazilian Organized Crime Act 2013, art $4 \$ 4$.

1006 See item I.4.a.ii.

1007 See item I.4.a.iii.

1008 See item I.4.a.i.

1009 See item I.4.a.iv.

1010 See item I.4.b. 
The clear detachment between the text of the Organized Crime Act and the emergent 'law in action' has often been justified by the notion that the rewarded collaboration regulation is a part of a developing paradigm of "consensual criminal justice". ${ }^{1011}$ In this context, concepts normally associated with private contract law have emerged as tools to interpret and develop the provisions of the rewarded collaboration regulation. ${ }^{1012}$ The elastic system of transactions is also repeatedly justified on efficiency grounds: the successful investigation of sophisticated criminal organizations depends, in this view, on flexible tools, allowing a more effective prosecution of powerful offenders, particularly in the realm of white-collar criminality. ${ }^{1013}$

This section argues that this contractualist approach to collaboration agreements misunderstands the function fulfilled by the rewarded collaboration regulation in Brazilian law and seriously undermines basic values protected by the Brazilian system of criminal justice. Furthermore, it asserts that the inventive practice of collaboration agreements has counterproductive effects and maximizes the inherent risks of leniency policies.

1011 See item I.4.c. For an emphatic defense of this position, see: Mendonça (n 36). This position also gained recognition in a decision of the Brazilian Federal Supreme Court. See STF, PET 7074 [2017] (Celso de Mello J). On different occasions, the Federal Public Prosecution Office associated the rewarded collaboration regulation with a "system of consensual justice", defending its interpretation according to the "principle of the consensual due process of law". See its allegations in the following proceedings: STF, PET 7265 [2017] and STF, PET 5779 [2015].

1012 See items I.4.c.i and I.4.c.ii. Several judicial decisions of Brazilian higher courts followed this line of reasoning. See items I.4.c.i and I.4.c.ii. Several judicial decisions of Brazilian higher courts followed this line of reasoning. See STF, HC 127483 [2015]; STF, PET 7074 [2017] and STF INQ 4405 AgR [2018]. Several authors defend the interpretation of the rewarded collaboration regulation according to traditional principles of private contract law, such as individual autonomy, contractual stability and protection of legitimate expectations. See Daniel Sarmento, 'Colaboração premiada. Competência do relator para homologação e limites à sua revisão judicial posterior. Proteção à confiança, princípio acusatório e proporcionalidade', in Daniel Sarmento (eds), Direitos Democracia e República (Fórum 2018); Alexandre Morais da Rosa, 'A aplicação da pena na justiça negocial: a questão da vinculação do juiz aos termos da delação', in Américo B Júnior and Gabriel SQ Campos (eds.), Sentenca criminal $e$ aplicação da pena: ensaios sobre discricionariedade, individualização e proporcionalidade (Juspodiuvm 2017).

1013 See section II.4. Also Dino, 'A colaboração premiada na improbidade administrativa: possibilidade e repercussão probatória'(n 425) 533; Kurtenbach and Nolte (n 16) 5. 
Item V.2.a argues that, like the German crown-witness regulation, the Brazilian rewarded collaboration regulations represents an extraordinary investigative tool to be employed under specific circumstances, and not a facet of the parties' discretionary powers to dispose of criminal proceedings. From this perspective, item V.2.b asserts that collaboration agreements must respect the guarantee of due process and cannot alter the natural chain of events of Brazilian criminal procedure. Item V.2.c sustains that the rewarded collaboration regulation did not modify the system of separation of functions within Brazilian criminal justice, and that collaboration agreements must respect the exclusive powers of judicial bodies in the determination of the verdict and the sentence. Item V.2.d affirms that, because the legitimacy of collaboration agreements stems from investigative successes achieved at the end of criminal proceedings, premature definition of the cooperator's benefits and punishment carries serious risks for the sound development of a sound leniency policy.

a. Collaboration agreements as exceptional tools for investigative emergencies

The introduction of leniency policies, such as the Brazilian rewarded collaboration regulation, expands the field of action of parties in criminal procedure. They enable defendants to cooperate with the investigations and obtain benefits that did not exist before. They also allow law enforcement authorities to develop cooperative relationships with offenders in order to obtain information and evidence from an internal source of the criminal organization. This process of fact-finding is clearly different from the use of other investigative techniques, such as the interception of communications and the execution of searches and seizures. Its success depends on the conversion of an offender, who has profited from wrongdoings, into an active partner of state authorities. ${ }^{1014}$ Thus, leniency policies require a very different attitude from law enforcement authorities compared to traditional investigative tools. Instead of gathering evidence directly with the use of state prerogatives, they must dialog with offenders

1014 Florian Jeßberger notes that leniency policies create a scenario where the defendant is both the object and subject of a criminal investigation. See: Jeßberger, Kooperation Und Strafzumessung: Der Kronzeuge Im Deutschen Und Amerikanischen Strafrecht (n 1) 26. 
and persuade them to, in exchange for some benefits, cooperate in the investigation against co-conspirators. ${ }^{1015}$

Under what circumstances should law enforcement authorities engage in these negotiations? How should they select the individuals that deserve and will honor an agreement? How should they decide the benefits that each cooperator will receive?

The development of the Brazilian practice of collaboration agreements has clearly been influenced by the ample American experience with the use of cooperating defendants. ${ }^{1016}$ In the United States, the above questions are answered based on the assumptions that prosecutors have wide discretion in deciding the format and the fate of criminal proceedings, ${ }^{1017}$ that their decisions are connected to the system of local representation ${ }^{1018}$ and that they are ultimately controlled by the democratic electoral process. ${ }^{1019}$ The concept that criminal proceedings are disputes between two parties leads to a scenario where cooperation between offenders and enforcement authorities appears as a normal feature of the U.S. criminal justice. ${ }^{1020}$ The particular structure of American criminal procedure, that rests upon the notion that procedural parties are the "real owners of the process", ${ }^{1021}$ has made the use of cooperating defendants a common and widespread reality. ${ }^{1022}$

1015 The foreseeable concession of benefits is a key part of a leniency policy. Stefanie Mehrens observes that a distinctive feature of leniency policies is the granting of a specific compensation in return for a concrete assistance in an investigation. According to the author, "The compensation comprises normally not a financial sum, but a benefit in the criminal proceeding regarding the conduct of the cooperator". See: Mehrens (n 11) 30.

1016 See item I.4.c.

1017 Dubber and Hörnle note that: "Prosecutorial discretion in the U.S. system, however, is essentially unconstrained (...)" . See: Dubber and Hörnle (n 670). On the same note, Jaeger asserts that "American prosecutorial bodies have a discretion over the criminal proceeding that is virtually unrestricted and beyond control". See: Jaeger (n 3).

1018 Robert L Misner, 'Recasting Prosecutorial Discretion' (1996) 86 Journal of Criminal Law and Criminology 717, 731. On this point, Dominik Brodowsky observes that the legitimacy of the discretionary powers of American prosecutors arise from the political system. See: Brodowski (n 24) 742.

1019 Langbein (n 682) 445-446.

1020 Jaeger (n 3) 274.

1021 Langer (n 28) 36.

1022 Jeßberger, Kooperation Und Strafzumessung: Der Kronzeuge Im Deutschen Und Amerikanischen Strafrecht (n 1) 153-154. 
Because of their wide discretionary powers, U.S. prosecutors are generally free from constraints when it comes to selecting the situations where cooperation with offenders is appropriate. ${ }^{1023}$ The broad discretion conferred upon prosecutorial bodies allows them to make and honor specific promises to cooperating defendants without depending on the decisions of judicial bodies. ${ }^{1024}$ The enormous freedom of action of American prosecutors enables the use, in agreements with offenders, of techniques similar to those employed by private attorneys in the negotiation of contractual arrangements. ${ }^{1025}$ Promises of benefits and threats of retaliation, for example, are natural elements of this negotiation process. ${ }^{1026}$

In Continental tradition countries, the situation is completely different, since the structure of criminal procedure - based on principles such as legality and compulsory prosecution - restricts the possibilities for negotiations between law enforcement authorities and offenders. ${ }^{1027}$ Because

1023 According to Ian Weinsten, this wide discretion generates strong discrepancies in the "cooperation market" in U.S. criminal justice. The author observes that "cooperation is unevenly distributed and subject to wide variations in local practices and policies" and that "the system is rife with individual and districtto-district disparities". See: Weinstein (n 3) 564.

1024 Jeßberger, Kooperation Und Strafzumessung: Der Kronzeuge Im Deutschen Und Amerikanischen Strafrecht (n 1) 208-209.

1025 Whitman asserts that "American prosecutors have the widest range of charging discretion. Indeed, they bring the same spirit of inventiveness to their task that American business lawyers bring to the drafting of contracts". See Whitman (n 244) 387.

1026 Luis Greco notes that it is acceptable in the U.S. justice system for prosecutors to threaten to present harsher charges in order obtain the consent of the defendant. See: Greco, Strafprozesstheorie Und Materielle Rechtskraft (n 668) 278. Regarding this matter, the U.S. Supreme Court has decided that: "The Due Process Clause of the Fourteenth Amendment is not violated when.a State prosecutor carries out a threat made during plea negotiations to have the accused reindicted on more serious charges on which he is plainly subject to prosecution if he does not plead guilty to the offense with which he was originally charged." See See Bordenkircher v. Hayes, 434 U.S. 357 (1978).

1027 In Germany, Lorenz Frahm points out that incompatibility with the principle of compulsory prosecution ("Legalitätsprinzip") was the most common argument against the introduction of the crown-witness regulation See: Frahm (n 482) 167. Similarly: Hoyer (n 442) 234; Buzari (n 12) 68-69. Comparing the prosecution of corporate wrongdoings in U.S. and in continental countries, Ana Pena asserts that in the latter ones "the principle of legality prevents prosecutors from not bringing charges when a crime has been committed. Therefore, the power to negotiate agreements is more reduced, at least in theory". See: Neira Pena (n 375) 205. 
criminal procedure is understood not as a simple dispute between two parties, but rather as an official investigation to ascertain whether a crime has been committed and by whom, the parties' capacity to dispose of criminal cases is much smaller than in the American criminal justice system. ${ }^{1028}$ Judicial bodies play a central role in the fact-finding process, overseeing and reviewing decisions of public prosecutors to guarantee an accurate and impartial reconstruction of past events. ${ }^{1029}$ The granting of benefits to cooperating defendants cannot stem from discretionary concessions of public prosecutors, since such discretionary powers do not exist or are very narrow. ${ }^{1030}$

As the German experience shows, the use of cooperating offenders to investigate co-conspirators has, in a context where a criminal proceeding is understood as an official investigation, very different foundations and, consequently, follows a distinct rationale when compared to the American experience. ${ }^{1031}$ While in the U.S. the granting of benefits to cooperators arises - due to particularities of the party-driven criminal procedure - as a common feature and a recurrent practice, in the structure of German criminal justice it can occur only as an exceptional response to situations of investigative emergencies ("Ermittlungsnotstand"), which arise when serious obstacles hinder an appropriate inquiry of serious crimes. ${ }^{1032}$ The so-called crown-witness regulation represents a relaxation - occasional and limited of traditional pillars of German criminal procedure that can be employed only under specific circumstances. ${ }^{1033}$ As an extraordinary reaction to extraordinary situations, ${ }^{1034}$ the development of cooperative relationships between public authorities and offenders must strictly abide by statutory rules, which circumscribe the applicability and define the conditions of these exchanges. ${ }^{1035}$ The effectiveness of the justice system cannot depend on the routine granting of benefits to offenders, since that would contra-

1028 Langer (n 28) 22.

1029 Schünemann stresses the central role played by courts in German criminal procedure. See: Bernd Schünemann, 'Die Zukunft des Strafverfahrens - Abschied vom Rechtsstaat?’ (2007) 119 ZStW 945, 946.

1030 Comparing the legitimacy of the discretionary decisions of American and German prosecutors, see: Brodowski (n 24) 773-776.

1031 Jeßberger, Kooperation und Strafzumessung: der Kronzeuge im deutschen und amerikanischen Strafrecht (n 1) 304; Jaeger (n 3 ) 266-268.

1032 On the requirement regarding the existence of investigative emergencies ("Ermittlungsnotstand"), see item III.3.c.

1033 Hoyer (n 442) 240.

1034 Jung (n 442) 42.

1035 Schlüchter (n 495) 69. 
dict basic principles of German criminal justice. ${ }^{1036}$ Nor can the crownwitness regulation become a tool for public prosecutors to manipulate the criminal procedure and circumvent their legal duties. ${ }^{1037}$

These differences reflect on how cooperation with offenders is implemented within the justice system: whereas in American procedure prosecutors have discretionary powers to make and honor promises that favor the cooperator, in Germany judicial bodies play a central role in the definition and granting of the benefits. ${ }^{1038}$ The German general crown-witness regulation, introduced in 2009, establishes a relationship of exchange between the cooperating defendant and the state in which the public authorities receiving the cooperation (the police and prosecutors) are not the same authorities responsible for determining the cooperator's benefits (the judicial bodies). ${ }^{1039}$ The regulation also devises a temporal separation between the moment of assistance and the moment of definition of the cooperator's legal situation: while cooperating defendants must provide the relevant information and evidence before the beginning of the criminal process, only at the sentencing phase will the consequences of their conduct be determined. ${ }^{1040}$

Since the concession of privileges to cooperating offenders constitutes a departure from traditional pillars of German criminal procedure, it can only be accepted when clear thresholds are met. The provided material must lead to a concrete investigatory achievement ("Aufklärungserfolg”), effectively contributing to the prosecution of individuals who would otherwise go unpunished. ${ }^{1041}$ The defendant's mere confession is insufficient to support the granting of benefits established by the crown-witness regulation. ${ }^{1042}$ The sharing of generic information, of speculative versions or of narratives without evidence also does not justify any differential treatment. ${ }^{1043}$ The assistance provided by the defendant must represent an es-

1036 Jung (n 442) 40.

1037 Jeßberger, Kooperation Und Strafzumessung: Der Kronzeuge Im Deutschen Und Amerikanischen Strafrecht (n 1) 307.

1038 See item III.3.b.

1039 Malek, 'Die Neue Kronzeugenregelung Und Ihre Auswirkungen Auf Die Praxis Der Strafverteidigung' ( $\mathrm{n}$ 481) 203.

1040 As provided in the German Criminal Code $(S t G B), \$ 46 \mathrm{~b}(2) 2$.

1041 On the issue of investigative achievements, see item III.4.d.

1042 Item IV.3.b. See Buzari, Kronzeugenregelungen in Straf- und Kartellrecht unter besonderer Berücksichtigung des $\$ 46 b$ StGB (Strafrecht in Forschung und Praxis) (n 12) 55 .

1043 ibid 52. 
sential contribution ("wesentlicher Beitrag") to the discovery or prevention of serious criminal activities; ${ }^{1044}$ for this purpose, the simple confirmation of information already possessed by authorities is not enough. ${ }^{1045}$ Furthermore, the use of the crown-witness regulation needs to result in a positive balance regarding the punishment of all the accused. ${ }^{1046}$ The reduction of the cooperator's penalties can be accepted only when associated with a significant increase of the criminal punishment imposed upon the other coconspirators. ${ }^{1047}$

There are, therefore, significant contrasts in the use of cooperating defendants in a system of official investigation, like Germany, when compared to jurisdictions where criminal procedure is understood as a dispute between two conflicting parties, as in U.S. criminal justice. ${ }^{1048}$ This provides an interesting perspective for analyzingvarious controversies regarding the Brazilian rewarded collaboration regulation and the developments implemented by legal practitioners.

As in the German system and other jurisdictions of Continental tradition, the development in Brazil of cooperative relationships between offenders and enforcement authorities cannot derive from the authorities' wide discretionary powers to dispose of criminal procedures, since this type of discretion does not exist in Brazilian criminal justice. ${ }^{1049}$ Public

1044 Kneba (n 861) 66.

1045 Frahm (n 482) 54-55.

1046 Jeßberger, Kooperation Und Strafzumessung: Der Kronzeuge Im Deutschen Und Amerikanischen Strafrecht (n 1) 102-103.

1047 Hoyer (n 442) 236.

1048 For an analysis of the differences between the concept of criminal proceeding as a "dispute" and as an "official investigation", see Langer (n 28) 20-24.

1049 In an important decision regarding the use of the negotiation mechanisms provided for in the Small Claims Act, the Brazilian Federal Supreme Court recognized that, in Brazilian criminal justice, "compulsory prosecution is the rule; the prosecutor is constrained to present charges, whenever there exist legal and factual grounds for the indictment". The decision acknowledged that the rule of compulsory prosecution could be loosened in specific situations established in the Small Claims Act, granting prosecutors a margin of discretion to negotiate with defendants in proceedings related to minor offenses. However, even in those situations, the Federal Supreme Court affirmed that the loosening of the rule of compulsory prosecution could not open space for "the free enlargement of personal temperaments, the subjectivism of criteria or the daily emotion of each prosecutor, throughout Brazil." For this reason, the decision authorized courts to monitor and eventually challenge the decisions made by prosecutors in the negotiations engendered by the Small Claims Act. See STF, HC 75343 [1997]. 
prosecutors and defendants do not represent, in Brazilian criminal procedure, two disputing parties that contend before a passive referee. ${ }^{1050}$ Courts play a major role throughout the whole process of fact-finding, which is understood not as a clash between two alternative versions presented by each contender, but rather as an official investigation into what really occurred and who is responsible for it. ${ }^{1051}$ Given the judicial commitment to ascertaining the facts, the confession of an accused is insufficient to justify a criminal conviction and constitutes only an additional piece of evidence to be analyzed by the court. ${ }^{1052}$ Therefore, accused cannot dispose of the criminal procedure through confession of the facts, and the state's commitment to an adequate reconstruction of the facts prevents defendants from waiving basic procedural rights. ${ }^{1053}$

1050 Regarding the role of the prosecutor in the Brazilian criminal justice system, a recent decision of the Brazilian Superior Court of Justice affirmed that "the Public Prosecution Office, regardless of being a formal part of the criminal proceeding, acts in an objective manner, fulfilling its duty to verify the correct observance of law and to ensure the observance of the defendant's rights and guarantees." Because of this position, the Prosecution Office has "the duty to press charges whenever the legal prerequisites are present, committed with the discover of truth and the pursuit of justice." See STJ, REsp 1340709 [2014].

1051 The Brazilian Criminal Procedural Code empowers courts to ascertain facts and determine ex officio the production of evidence. A recent decision of the Federal Supreme Court validated these powers, asserting that the principle of impartiality "does not oblige courts to adopt a mere contemplative stance, especially because of the principle of search for the material truth that guides criminal procedure.” See STF HC 126501 [2016] (Marco Aurélio J).

1052 The Brazilian Code of Criminal Procedure explicitly provides that courts have the duty to compare a defendant's confession with other pieces of evidence to ascertain their compatibility. See Brazilian Code of Criminal Procedure, art 197. Countless judicial decisions affirm the basic rule that a mere confession is insufficient to justify a criminal conviction. The Federal Supreme Court, for instance, has decided that a confession "must not necessarily lead to the conviction of the defendant" and that "a confession, when incompatible with other pieces of evidence, must be appraised with caution.” See STF, RHC 91691 [2008] (Menezes Direito J).

1053 On this point, a ruling of the Brazilian Superior Court of Justice affirmed that the defendant's right to contest the charges "also concerns the State, since it aims at clarifying the facts in search for the material truth." See STJ, RHC 13985 [2003]. Another ruling of the Court decided that: "The right of defense can not be waived, and it can not be disposed of by the accused, his lawyer, the Prosecution Office, even when the accused admits the wrongdoing and is willing to serve the penalty." See STJ, RHC 15.258 [2004]. For a strong defense of the position that the Brazilian Constitution prevents the free disposition of the 
The notion that parties cannot freely dispose of criminal cases is a core concept of the Brazilian criminal justice system, with various consequences across the structure of criminal proceedings, limiting the field of action of law enforcement authorities and allowing for strict judicial control at different phases of the process. According to Brazilian criminal procedure, the Public Prosecution Office is not allowed to withdraw a criminal charge ${ }^{1054}$ or an appeal after it has been filed. ${ }^{1055} \mathrm{~A}$ request for acquittal by the Public Prosecution Office does not bind the judicial organ, which may convict the defendant and acknowledge aggravating circumstances even if they are not raised by the prosecutor. ${ }^{1056}$ The decision to close an investigation and not to press charges can also be questioned by courts. ${ }^{1057}$

In this context, the introduction of the rewarded collaboration regulation by the Organized Crime Act appears - just like the German crownwitness regulation ${ }^{1058}$ - as an extraordinary investigative measure to overcome situations of extreme difficulty in the discovery and prosecution of serious crimes. ${ }^{1059}$ In Brazilian law, the legitimacy of collaboration agreements arises not from the parties' power to freely dispose of criminal proceedings, but from a specific and limited statutory authorization, which seeks to increase the state's capacity to punish and prevent the activities of criminal organizations. In this context, cooperation between offenders and enforcement authorities represents an exceptional tool for guaranteeing an adequate finding of facts and effective evidence collection in scenarios of investigative emergencies. From this perspective, the practice of collaboration agreements can be more thoroughly analyzed.

right to defense in criminal procedure, see the ruling of the Federal Supreme Court in STF, HC 70600-2 [1994].

1054 Brazilian Code of Criminal Procedure, art. 42. In this regard, the Brazilian Federal Supreme Court has already decided that the Public Prosecutor's Office the principle of compulsory prosecution prevents the Public Prosecution Office of withdrawing an appeal that has been already filed. See STF, AP 905 QO [2016].

1055 Brazilian Code of Criminal Procedure, art 576.

1056 Brazilian Code of Criminal Procedure, art 385.

1057 In this situation, the investigation will be sent to the Prosecutor General, who will be responsible for the decision to present the indictment, to appoint another member of the Public Prosecutor's Office to handle the case or to reiterate the request for closure, in which case the court will be obligated to accept it. See Brazilian Code of Criminal Procedure, art 28.

1058 Jung (n 442) 42.

1059 Defending the argument of investigative emergencies as plausible in the Brazilian context, there is: Frederico V Pereira, 'Compatibilização Constitucional Da Colaboração Premiada' (2013) 17 Revista CEJ 84, 91-92. 
b. Due process, search for truth and the chain of events in criminal procedure

The Brazilian Organized Crime Act provides that courts may grant judicial pardon, reduce the imprisonment sentence by up to two-thirds or substitute an imprisonment sentence for penalties of restriction of rights for defendants who successfully cooperate with law enforcement authorities, leading to an effective outcome. ${ }^{1060}$ According to the statutory provisions, while law enforcement authorities (the Public Prosecution Office or the chief of police) are responsible for the negotiation and conclusion of collaboration agreements, the reduction of a cooperator's penalties is to be defined by a judicial decision at the end of the criminal proceeding. ${ }^{1061}$

In the practice of collaboration agreements, however, collaboration agreements - instead of outlining the benefits provided for by the statute have defined the exact punishment of the cooperating defendant, stipulating precisely the length of the imprisonment penalty and the period that the cooperator must spend in each detention regime. ${ }^{1062}$ The Brazilian practice of collaboration agreements has also developed a model of "package deal", which allows cooperating defendants to simultaneously negotiate a single overall penalty for a series of confessed crimes, even when they are investigated by different criminal proceedings. ${ }^{1063}$

In this system of agreements, the negotiation unfolds through the definition of a unified punishment that encompasses all conducts described in the cooperation report, and not through the establishment of the different crimes committed by the cooperator and the imposition of the correspondent penalties with the applicable benefits. In the Brazilian practice of collaboration agreements, the Public Prosecution Office and the cooperating defendant negotiate for long periods of time, in confidential and informal meetings, before reaching a consensual arrangement. ${ }^{1064}$ When they reach a final common position, the concluded written agreement, laying down the exact negotiated punishment, and the cooperation report - often containing confession, evidence and information about a myriad of suspected conducts - are submitted for homologation to the competent judicial

1060 See item I.3.b.ii.

1061 See item I.3.c.

1062 See item I.4.a.ii.

1063 See item I.4.a.iii.

1064 See item I.3.a. 
body, who must verify the agreement's "regularity, legality and voluntariness". ${ }^{1065}$

The exact definition, in collaboration agreements, of the cooperator's punishment and the model of "package deals" raise serious questions regarding the guarantee of due process, since this type of arrangement leads to a very different order of events when compared to the traditional Brazilian criminal procedure. Given that collaboration agreements are normally concluded at early stages of the investigations, sometimes even prior to the filing of any formal charges, this type of transaction entails that the outcome of the investigation is already determined before the facts of the case have been established in trial, engendering a complete inversion of the ordinary course of events of a criminal proceeding.

In the United States, parties have wide freedom to alter the course of criminal proceedings through consensual arrangements. ${ }^{1066}$ Throughout the whole process, prosecutors have the discretionary power to drop or modify the charges against the accused. ${ }^{1067}$ The defendant, in turn, has the option of pleading guilty at any time. ${ }^{1068}$ Either one of these possibilities decisively affects the course of the criminal process, precipitating the end of the case. In these circumstances, the conclusion of a plea agreement between prosecutors and defendants represents a "break in the chain of events" of the criminal process: ${ }^{1069}$ all the previous acts become practically irrelevant and no further inquiry to determine the guilty of the accused is necessary.

1065 Brazilian Organized Crime Act 2013, art 4 \$7.

1066 According to Maximo Langer, the understanding that the parties are the "owners of the process" and that judges are passive observers is a key factor for the development of negotiation practices. See: Langer (n 28) 36.

1067 Dominik Brodowski observes that the wide room for maneuver obtained by American prosecutors arises from (i) the strong attachment of judicial bodies to the prosecutorial charges and (ii) from the absence of statutory limits to prosecutorial discretion. See: Brodowski (n 24) 740-741.

1068 According to Bernd Scünemann, the concept of "guilty plea" can be understood as a normal consequence of "a radical form of party-driven criminal procedure”. See: Schünemann, 'Zur Kritik Des Amerikanischen Strafprozessmodells' (n 25) 565.

1069 As famously established by the U.S. Supreme Court in Tollett v. Henderson (411 U.S. 258 - 1973): "a guilty plea represents a break in the chain of events which has preceded it in the criminal process. When a criminal defendant has solemnly admitted in open court that he is in fact guilty of the offense with which he is charged, he may not thereafter raise independent claims relating to the deprivation of constitutional rights that occurred prior to the entry of the guilty plea”. 
The negotiation forum established by the Brazilian Criminal Organized Act, however, clearly has different characteristics. The rewarded collaboration regulation did not design a fast-track route to the premature resolution of criminal investigations, but rather enabled the development of cooperative relationships between enforcement authorities and offenders. ${ }^{1070}$ As occurs in the German crown-witness regulation, ${ }^{1071}$ these relationships are developed within the traditional criminal procedure, and do not replace it.

The conclusion of collaboration agreements causes the broadening or, sometimes, even the opening of official investigations. It allows law enforcement authorities to access evidence and information that until then was known only to the cooperator. These new pieces of evidence will have to be analyzed throughout the trial, and there is no guarantee that they will generate a conviction of the cooperating defendant or other accused. ${ }^{1072}$ The scenario of the cooperator's acquittal is not a hypothesis that can be ruled out, but rather a reality that may occur.

In the Brazilian legal system, the imposition of imprisonment penalties depends on the regular course and completion of the proceeding, which includes the formal indictment of the accused, the gathering of evidence and, finally, the verdict rendered by a judicial body, which is responsible for assessing the defendant's criminal liability. ${ }^{1073}$ The sentencing phase, in which courts, based on the elements gathered throughout the proceeding, analyze the objective characteristics of the crime and the subjective particularities of the defendant, can only occur after the rendering of a judicial verdict on the defendant's guilt.

Thus, collaboration agreements in Brazilian law do not represent a break in the natural chain of events of the criminal process, which must follow a logical sequence of stages to (i) investigate suspicious facts through the regular production of evidence before a court, (ii) assess the

1070 For a more detailed analysis of the characteristics of these cooperative relationships, see section V.3.

1071 For the examination of the German experience, see items IV..3.b and IV.4.ii.

1072 For a comparison between Brazilian collaboration agreements and American plea agreements, see item V.3.d.

1073 On this point, the Brazilian Federal Supreme Court has already decided, in a case involving the consensual mechanisms provided by the Small Claims Act, that the seizure of criminal assets and other legal consequences associated with a criminal conviction can only occur after a judicial verdict rendered at the end of the criminal proceeding, demanding the regular collection of evidence. See STF, RE 795567 [2015]. 
guilt of the defendant and (iii) determine, in the case of a guilty verdict, the sentence. ${ }^{1074}$ The definition and serving of imprisonment penalties can only occur at the final stage of the procedure, once the question of the criminal liability of the accused has already been resolved. The sequential and progressive logic of the criminal procedure is inherent to the constitutional guarantee of due process. ${ }^{1075}$

The statutory rules of the rewarded collaboration regulation do not contradict this sequential logic. The Organized Crime Act did not alter the structure of the Brazilian Criminal Procedure Code and, according to the statutory provisions, the cooperator's situation is to be defined by the judicial body at the end of the proceeding. ${ }^{1076}$ It is only at this moment that the evidence related to the investigated facts, the guilt of all defendants (including the cooperator) and the usefulness of the collaboration agreement can be properly evaluated. The Organized Crime Act introduced collaboration agreements as an exceptional tool for the collection of evidence in situations of investigative emergencies, and not as a new type of criminal procedure in which parties can freely dispose of criminal punishment.

Despite that, the Brazilian practice of collaboration agreements has repeatedly established, in consensual arrangements concluded at very early stages of the investigation, the exact criminal punishment imposed upon cooperating defendants, allowing them, in some cases, to serve the penalties in advance. This definition of imprisonment penalties before the completion of the investigation and verdict phases breaches the logic of Brazilian criminal procedure, in a clear violation of the guarantee of due process. ${ }^{1077}$ Without the prior establishment of a factual basis, it is senseless to analyze the legal implications of the defendant's conduct. If the facts of the crime are yet to be determined, how is it possible that its legal consequences have already been exactly defined? If a judicial verdict is an essential requirement for establishing criminal liability, how can the cooperat-

1074 For a similar interpretation of the Brazilian rewarded collaboration regulation, see: Badaró (n 173).

1075 On this point, The Brazilian Federal Supreme Court has ruled that the Public Prosecution may not adopt procedural maneuvers that invert the logic of criminal process and that lead to situations in which issues related to sentencing are discussed before the completion of the collection of evidence and before the judicial assessment of the defendant's guilt. See STF, RE 602527 QO-RG [2009].

1076 Brazilian Organized Crime Act 2013, art $4 \$ 11$.

1077 Also noted by Cavali (n 36). 
ing defendant serve an imprisonment penalty before a formal proceeding has even started?

By establishing criminal punishment through an inter-party written agreement at the beginning of the proceeding, the Brazilian practice of collaboration agreements has transformed an investigative tool into a mechanism for consensual resolution of the process. In this model of transaction, the outcome of the investigation against the cooperating defendants derives solely from their acquiescence to the negotiated penalties established in the agreement, becoming disconnected from the factual finding that will occur during the criminal proceeding.

c. Separation of functions in criminal procedure: the return of the inquisitorial process?

In the Brazilian practice of collaboration agreements, the state's response to the alleged criminal behavior of the cooperator is decided through the negotiation with law enforcement authorities, and not from a judicial verdict on the factual aspects of the investigated conduct. This type of transaction, besides violating the guarantee of due process, is also incompatible with the model of separation of powers enshrined in the Brazilian justice system.

The introduction of the rewarded collaboration regulation clearly widens the field of action of prosecutors and defendants in criminal procedure, giving them the possibility to communicate, interact and devise a cooperative relationship. ${ }^{1078}$ Although the establishment of this negotiation forum is legitimate, it cannot be understood as a new model of criminal justice, different from the system set forth in the Brazilian Constitution and in criminal legislation, which impose a clear separation between the prosecutorial activities, on the one hand, and the adjudicative function, on the other. ${ }^{1079}$

1078 As noted by Florian Jeßberger: "Leniency policies open for the procedural participants additional and new room for maneuver (...)". See: Jeßberger, Kooperation Und Strafzumessung: Der Kronzeuge Im Deutschen Und Amerikanischen Strafrecht (n 1) 140.

1079 In a 2014 ruling, the Brazilian Federal Supreme Court affirmed that the Federal Constitution stipulated "a rigid separation between the tasks of investigating and accusing, on one side, and the adjudicative function, on the other." See STF ADI 5104 MC [2014] (Barroso J). 
This separation prevents judges from interfering in some decisions that fall within the responsibility of the Public Prosecution Office, ${ }^{1080}$ but also establishes a range of activities that can only be performed by judicial bodies. ${ }^{1081}$ Among these exclusive judicial functions is the power to decide on the guilt or innocence of the accused and to impose, through a judicial sentence, an imprisonment penalty. In Brazilian criminal procedure, the defendant's conduct is assessed through an official and impartial investigation and the determination of the defendant's guilt is an act performed by courts or, in very specific situations, by juries. ${ }^{1082}$ According to the Brazilian Code of Criminal Procedure, the offender's confession does not entail the end of the official investigation, which is mandatory even in cases where the suspect has confessed to the crime. ${ }^{1083}$ The defendant may at any time withdraw their confession and the judge must establish the veracity of a confession taking into account all the evidence collected during the regular proceeding. ${ }^{1084}$

Furthermore, the definition of a criminal sentence is also an inalienable function of the judiciary, which must impose a penalty consistent with the objective and subjective circumstances of each specific case. ${ }^{1085}$ Given the guarantee of individualization of criminal punishment, the judicial power to define the appropriate sentence for each defendant enjoys constitutional status and cannot be suppressed. ${ }^{1086}$

1080 In this regard, the Federal Supreme Court has already decided that courts cannot determine the amendment of the indictment presented by the Public Prosecution Office to add facts contained in the police report. See STF, RHC 120379 [2014].

1081 Those are activities in which, as observed by the Federal Supreme Court, "the Judiciary not only has the final word, but, above all, has the unquestionable prerogative to say the first word, thus excluding, by virtue of the Constitution, the possibility of other State bodies and authorities exercising the same duties." See STF, MS 23452 [1999].

1082 In Brazil, juries are responsible for assessing the defendant's guilt in willful crimes against life. See Brazilian Federal Constitution, ar. 5 XXXVIII indent "a", and Brazilian Code of Criminal Procedure, art $74 \rrbracket 1$.

1083 Criminal Procedure Code, Article 158.

1084 Criminal Procedure Code, Article 200.

1085 In this regard, see the ruling of the Brazilian Federal Supreme Court asserting that the definition of a criminal sentence must respect "the judicial circumstances, that is, the objective and subjective facts determined in the criminal process.” See STF, HC 82959 [2006] (Marco Aurélio J).

1086 The Brazilian Federal Supreme Court has issued different rulings affirming the constitutional relevance of the sentencing phase and considering unconstitutional laws that limit the capacity of judicial bodies to define a sentence ad- 
The introduction of the rewarded collaboration regulation does not change this model of separation between the prosecutorial and adjudicative functions. Collaboration agreements are designed to initiate or expand an official investigation, and not resolve it. All evidence obtained by means of a collaboration agreement must be confirmed throughout the proceeding, at the end of which the competent judicial body shall assess the guilt, define the legal qualification of the criminal conduct and determine an appropriate sentence for all accused, including the cooperating defendant. The conclusion of a collaboration agreement, therefore, does not exempt judicial bodies from their obligation to oversee an impartial investigation of the facts, analyze carefully the produced evidence, assess the defendant's guilt and impose a sentence compatible with the particularities of the case.

Viewed in this light, the Brazilian practice of collaboration agreements shows complete disregard for the system of separation of functions in Brazilian criminal justice. ${ }^{1087}$ In the comprehensive model of negotiation developed by legal practitioners, public prosecutors amass an enormous set of powers, predefining - through consensual arrangements negotiated secretly with defendants - practically every issue of the criminal proceeding. When the case is submitted for the judicial verdict, even the conditions under which the sentence will be served have already been determined. Regarding the establishment of the cooperator's punishment, courts become bystanders of a play with a predefined end, written jointly by defendants and prosecutors

The irony of the situation is hard to miss. Support for the large-scale use of collaboration agreements is often based on the concept that these mechanisms embody the values of a new - more modern - system of consensual criminal justice. ${ }^{1088}$ Examined more closely, the Brazilian practice of collaboration agreements shows a striking resemblance to antique inquisitorial procedures, in which criminal punishment was defined through a "secret, professional, goal-oriented and undisturbed" process. ${ }^{1089}$

equate to the circumstances of each defendant. See STF, HC 97.256 [2010] and STF, HC 82959 [2006].

1087 In a similar sense, see Canotilho and Brandão (n 36) 27.

1088 See item I.4.c.

1089 Expressions used by Winfried Hassemer to criticize the German practice of informal negotiated judgments. See Hassemer, 'Pacta Sunt Servanda - Auch Im Strafprozess?' (n 679) 895. 
d. Investigative achievements, information asymmetry and the risks of forward purchases in the practice of collaboration agreements

Besides violating the due process guarantee, the early definition and imposition of criminal punishment in collaboration agreements also raises concerns about the effectiveness of the rewarded collaboration regulation. In the Brazilian justice system, as in German criminal law, the use of cooperating defendants occurs not as an everyday operation arising from the broad and discretionary powers of law enforcement authorities, but rather as an extraordinary response to extreme situations of investigative emergencies. ${ }^{1090}$ In both jurisdictions, cooperation between defendants and enforcement authorities represents an exceptional tool to enhance the state's capacity to control sophisticated criminal structures, and not a facet of the procedural participants' discretion.

Collaboration agreements, like other leniency policies, are utilitarian mechanisms. ${ }^{1091}$ They must play the role of investigative trampolines, enabling official authorities to go further in their task of enforcing criminal law. ${ }^{1092}$ The rewards conferred through collaboration agreements depend, consequently, on clear investigative achievements resulting directly from the cooperation. The favorable treatment conferred on cooperators arises not from the mere confession of their own acts, but from an effective contribution to the prosecution of third parties. ${ }^{1093}$ The knowledge and evidence shared must be accurate and relevant, representing a substantial contribution to establish the criminal liability of other agents. ${ }^{1094}$ A qualified causal link must exist between the material provided by the cooperating defendant and the enhancement of the investigation against other accused. ${ }^{1095}$

In addition to producing a concrete investigative achievement, the use of the rewarded collaboration regulation must also produce a positive balance in the overall level of imposed penalties. ${ }^{1096}$ The granting of benefits to an offender can occur only if it optimizes the level of punishment ap-

1090 See item V.2.a.

1091 On the utilitarian nature of leniency policies, see section III.2.

1092 Hoyer (n 442) 237.

1093 Jeßberger, 'Nulla Poena Quamvis in Culpa: Ammerkungen Zur Kronzeugenregelung in $\$ 46$ StGB' $^{\prime}(\mathrm{n} 2)$ 1153-1154.

1094 Kneba (n 861) 66.

1095 Hoyer (n 442) 237.

1096 On the need to achieve positive balances, see item IV.3.d. 
plied to the other investigated. ${ }^{1097}$ Although they create an amnesty effect for the cooperating defendant, leniency policies must, in a comprehensive perspective, bring the level of penalties closer to the ideal standard set by legislation, through the effective prosecution of other individuals who would remain unpunished without the cooperator's assistance. ${ }^{1098}$ Between the losses and gains engendered by leniency policies, there must remain a clear net profit. ${ }^{1099}$

In this context, the exact definition of the cooperator's punishment and benefits - through a package deal that sets a single penalty for a wide range of criminal conducts - at an early stage of the investigation entails serious risks for the public interest. Collaboration agreements give rise to durable partnerships between offenders and law enforcement authorities with the purpose of investigating and punishing other individuals. ${ }^{1100}$ The results of this enterprise depend on various external factors and are highly uncertain for both parties, even when they fully comply with all the terms of the agreement. ${ }^{1101}$ The shared information and evidence will have to face several tests of accuracy and legality before proving to be useful in the prosecution of third parties. A clear outcome will appear only after the completion of a complex process, which will involve several actors who did not take part in the consensual arrangement. ${ }^{1102}$

Thus, it is not possible to foresee, at the moment of conclusion of a collaboration agreement, the actual outputs that it will produce. Only at the end of the criminal proceeding can one assess the investigatory achievements brought about by the assistance provided by the cooperating defen-

1097 Jung (n 442) 40.

1098 Hoyer (n 442) 236.

1099 Jeßberger, Kooperation Und Strafzumessung: Der Kronzeuge Im Deutschen Und Amerikanischen Strafrecht (n 1) 102-103.

1100 For a more detailed analysis of these partnerships, see item V.3.c.

1101 Jeßberger, 'Nulla Poena Quamvis in Culpa: Ammerkungen Zur Kronzeugenregelung in $\$ 46$ StGB' $^{\prime}$ ( 2 ) 1163.

1102 As noted by David Moss in an analysis of the Italian experience with cooperating defendants: "for both the state and former terrorists, the full value of a confession-respectively, obtaining convictions and securing a reduced sentence -is only realised at the conclusion of the trial, when verdict and sentence are handed down. In practice, several different judges and juries are likely to be involved since confessions contain details of multiple crimes which may have to be tried separately and sentences are usually appealed to two tiers of higher courts". See: David Moss, 'The Gift of Repentance: A Maussian Perspective on Twenty Years of Pentimento in Italy' (2001) 42 Archives Europeennes de Sociologie 297, 303-304. 
dant. In this context, the early definition of the cooperator's punishment and benefits seems counterproductive, especially due to the many risks arising from the informational asymmetry that exists between the two signing parties.

Collaboration agreements, like other leniency policies, give rise to principal-agent relationships, in which law enforcement authorities have little knowledge about the defendant's activities and face great difficulties in monitoring the accuracy and correctness of the provided assistance. ${ }^{1103}$ As in other fiduciary relationships with such characteristics, the cooperative bond is vulnerable to exaggeration, omission and misrepresentation of facts, which may result from situations both of under-cooperation and over-cooperation. ${ }^{1104}$ In addition to the risk of factual misrepresentation, the informational asymmetry also creates opportunities for the obtainment of excessive benefits ${ }^{1105}$ and even for reinforcement of the criminal strategy. ${ }^{1106}$

Leniency policies pose a permanent danger of the excessive granting of benefits, maximizing the rewards for wrongful behavior, creating an easy way out for wrongdoers and reducing the overall deterrent effect of criminal law. ${ }^{1107}$ The premature definition of the exact punishment of the cooperating defendant at early stages of an investigation - when the informational asymmetry between public authorities and accused is at its peak greatly increases this danger. ${ }^{1108}$ In this type of transaction, the defendant guarantees upfront several benefits, while the state retains all the risks of a

1103 See section III.3. Also: Centonze (n 1).

1104 See item III.3.a.

1105 See item III.3.b.

1106 See item III.3.d.

1107 See: Catarina Marvão and Giancarlo Spagnolo, 'What do we know about the effectiveness of leniency policies? A survey of the empirical and experimental evidence', in Caron Beaton-Wells and Christopher Tran (eds), Anti-cartel enforcement in a contemporary age: leniency policies (Hart Publishing 2015) 57-80; Wils (n 378).

1108 The Brazilian Federal Police has recognized this risk in the practice of early definition of penalties through collaboration agreements. In a petition directed to the Brazilian Federal Supreme Court, it asserted: "A by-product of this practice is the possibility of the cooperating defendant to obtain benefits beforehand of clauses established in the agreement (...), albeit providing elements already present in the investigation or false, or concealing relevant information" (ADI 5508, Ofício 6/2017 - PF, Posicionamento da Polícia Federal - Colaboração Premiada, 08/08/2017, p. 18). 
possible investigative failure. ${ }^{1109}$ Besides contradicting basic pillars of Brazilian criminal procedure, the model of "package deals" developed in the practice of collaboration agreements also deviates from the rationale of a sound leniency policy. 1110

Lowering the cooperator's level of penalties can only be justified if it goes hand in hand with an increase in the punishment of third parties. The determination and granting of benefits depend, thus, on an effective and thorough demonstration that the cooperation provided by the defendant was useful for law enforcement authorities to identify and punish other individuals. This assessment can only be carried out after the completion of the investigation and verdict phases, exactly as determined by the text of the Organized Crime Act. Before that, there is no reliable basis for the definition and the attribution of privileged treatment to cooperators, since it is impossible to determine if (and to what extent) their assistance will be useful to prosecute and punish other suspects. ${ }^{1111}$

\section{Collaboration agreements as public-private partnerships within criminal justice: the privatization of truth-finding and its effect on third parties}

The practical development of the rewarded collaboration regulation is marked by the devising of consensual innovations in agreements concluded by cooperating defendants and public prosecutors. ${ }^{112}$ Over the years, procedural participants have used the negotiation forum designed by the Organized Crime Act to decide consensually on multiple issues of criminal proceedings, developing a broad and flexible system of transactions going far beyond the statutory provisions. The adoption of a tailor-made approach has generated complex and rich negotiated arrangements, which

1109 As noted by Florian Jeßberger, in the German crown-witness regulation the cooperating defendant is the main bearer of the risks of a failure in the investigation. See Jeßberger, 'Nulla poena quamvis in culpa: Ammerkungen zur Kronzeugenregelung in $₫ 46$ StGB' (n 2).

1110 Ian Weinstein also observes that, in the U.S. system of criminal justice, cooperating defendants bear the risk of not receiving any reward, despite their efforts to assist enforcement agencies. The author notes the "government's power to simply refuse to pay for cooperation”. See: Weinstein (n 3) 584.

1111 Defending this position, Brazilian Federal Police asserted that the "The efficacy of the collaboration can only be assessed at the end of the process of investigation, observed the due process of law" (ADI 5508, Ofício 6/2017 - PF, Posicionamento da Polícia Federal - Colaboração Premiada, 08/08/2017, p. 2).

1112 See item I.4.a. 
contain dozens of provisions and devise innovative solutions customized to address the peculiarities of each case. ${ }^{1113}$

The distinctive evolution of the Brazilian practice of collaboration agreements could not have occurred without the solid support of the judiciary. Brazilian courts, particularly the Brazilian Federal Supreme Court, have endorsed this versatile model of negotiation and validated the contractual creativity of legal practitioners. This quite often has been done based on the argument that collaboration agreements are part of a new model of consensual criminal justice, which has separate foundations and operates in a different manner from traditional Brazilian criminal procedure. ${ }^{1114}$ Throughout this process, the U.S. system of plea bargaining has clearly influenced the practice of collaboration agreements, providing the archetype of an effective criminal system that should be emulated. Besides the comparison with the model of plea bargaining, it is also common to correlate collaboration agreements with the consensual mechanisms established by the Brazilian Small Claims Act, that allow parties to resolve investigations of minor offenses through negotiated transactions. ${ }^{1115}$

This section argues that association of the Brazilian practice of collaboration agreements with the U.S. system of plea bargaining and with the ideal of consensual justice is conceptually mistaken, leading to unfounded and unacceptable consequences, among which the application of the the res inter alios acta doctrine stands out.

Item V.3.a asserts that collaboration agreements are intrinsically linked to the state's duty to search for truth, having different foundations and purposes when compared to mechanisms of consensual justice. Item V.3.b rejects the application, proposed by the Brazilian Federal Supreme Court, of the res inter alios acta doctrine to collaboration agreements. Item V.3.c advances the concept that collaboration agreements should be interpreted as durable public-private partnerships between law enforcement authorities and offenders, leading to a complex scenario of partial privatization of investigative and prosecutorial activities. Item V.3.d rebuffs the comparison between collaboration agreements and the U.S. model of plea bargaining, asserting that this analogy is misleading and can lead to perverse consequences in Brazilian law. Item V.2.d rejects the concept that parties can invent, through collaboration agreements, new benefits not provided for

1113 See item I.4.b.

1114 Rejecting this position, see item V.2.c.

1115 For a description of these mechanisms, see section I.1. 
by law, stressing the risks of a regime of contractual freedom for the sound development of leniency policies.

a. Triangular relationships, not bilateral transactions

The Brazilian Federal Supreme Court has decided on several occasions that collaboration agreements are legal transactions, concluded by the cooperating defendant and law enforcement authorities, which do not affect third parties. ${ }^{1116}$ According to this position, collaboration agreements create obligations and rights only for the contracting parties and do not affect the legal sphere of other defendants. ${ }^{1117}$ Based on this understanding, Brazilian courts refuse to examine judicial appeals filed by other accused regarding the legality of collaboration agreements, asserting that they are not part of the arrangement and, therefore, lack the right to interfere in a bilateral relationship. ${ }^{1118}$ This line of reasoning, which seeks to frame collaboration agreements in the classical model of private contracts, including through the application of the res inter alios acta principle, is seriously flawed and ignores the central features of the rewarded collaboration regulation.

Like the German crown-witness regulation, the Brazilian rewarded collaboration regulation seeks to maximize the state's capacity to prosecute and punish individuals responsible for serious crimes that are difficult to detect through traditional investigative tools. ${ }^{1119}$ As with the German crown-witness regulation, the legitimacy of the consensual exchanges under the Brazilian rewarded collaboration regulation stems from their capacity to strengthen the state's prosecution of other offenders in situations of investigative emergencies, and not from the parties' power to freely dis-

1116 See item I.4.c.ii. See e.g. STF, HC 127483 [2015] and STF, Pet 5885 AgR [2016].

1117 According to the Brazilian Federal Supreme Court: "the collaboration agreement, as a legal transaction of personal nature, does not bind a defendant accused by the cooperator and does not directly affect its legal sphere: res inter alios acta." See STF, HC 127483 [2015] (Toffoli J).

1118 There are several decisions of Brasilian courts affirming this position. See e.g. STJ, RHC 43776 [2017]; and STJ, HC 392452 AgInt [2017].

1119 For an analysis of the German crown-witness regulation, see item IV.3.a and IV.3.b. See also: Jung (n 442) 40; Frahm (n 482) 171-172. 
pose of criminal procedure. ${ }^{1120}$ The consensual exchanges between enforcement authorities and cooperating defendants clearly affect other individuals, since their main purpose is the establishment of a basis for imposing criminal punishment upon third parties. ${ }^{1121}$

The development of an evidentiary basis against third parties is both the starting point and the end goal in the negotiation of a collaboration agreement. It is the starting point because, if the offender does not possess information or evidence that is useful for the prosecution of other agents, there is no basis for the opening of a negotiation. ${ }^{1122}$ It is also the end goal because if the cooperation provided under an agreement proves for any reason to be wrong, false, or unnecessary in the investigation against other accused, there will be no legal basis for granting the benefits. ${ }^{1123}$

The rewarded collaboration regulation expressly conditions the degree of benefits obtained by the offender to the relevance and usefulness of the cooperation in the prosecution against co-conspirators. ${ }^{1124}$ In other words, there is a direct relationship between the level of benefits obtained by cooperating defendants and the potential of their cooperation to affect third parties. The more the material provided assists in the prosecution of other individuals, the greater the advantage that cooperating defendants can re-

1120 Analyzing the German scenario, see Jeßberger, Kooperation und Strafzumessung: der Kronzeuge im deutschen und amerikanischen Strafrecht, (n 1) 304-305. Stressing the need of the existence of an investigative emergency for the use of cooperating defendants, see: Hoyer (n 442) 240. Regarding the Brazilian context, see item V.2.a.

1121 Regarding this point, Stefanie Mehrens notes the similarities between the crown-witness regulations and the use of undercover agents. See: Mehrens (n 11) 29-30.

1122 Because of this requirement, it is common that individuals highly involved in serious crimes may access leniency policies, while agents with lower degree of culpability can not obtain the same benefits. Florian Jeßberger analyzes this situation and describes it as the problem of "big fish's privilege." See Jeßberger, Kooperation und Strafzumessung: der Kronzeuge im deutschen und amerikanischen Strafrecht (n 1) 271-274. In economic literature, there is a wide debate regarding whether ringleaders should be allowed to benefit from leniency policies. See: Iwan Bos and Frederick Wandschneider, 'A Note on Cartel Ringleaders and the Corporate Leniency Programme' (2013) 20 Applied Economics Letters 1100.

1123 Analyzing the German crown-witness regulation, Nicolas Kneba observes that the granting of benefits can only occur when there is a qualified causal link between the assistance provided by the cooperator and an investigative achievement against other accused. See: Kneba (n 861) 66. On the issue of investigative achievements, see item IV.3.d.

1124 Brazilian Organized Crime Act 2013, art 4, $\mathbb{1} 1$. 
ceive. Thus, not only is the production of negative effects upon third parties the purpose of collaboration agreements, but the maximization of such effects is also stimulated by the system of "quid-pro-quo" transactions established by the Organized Crime Act. ${ }^{1125}$

Viewed in this light, the rewarded collaboration regulation gives rise to a very specific situation: a negotiation forum in which a consensual arrangement between two parties depends on its capacity to cause adverse effects over another agent. In fact, in the absence of a third party that will be negatively affected by the arrangement, the conclusion of a collaboration agreement is simply impossible. ${ }^{1126}$

In this context, the Federal Supreme Court's understanding that collaboration agreements are pure bilateral contracts between the state and the offender is clearly mistaken. This position ignores the fact that the consensual understanding reached in collaboration agreements does not resolve a dispute between two parties, but rather initiates a relationship of cooperation directed to hold accountable other individuals, who did not participate in the conclusion of the agreement. ${ }^{1127}$ As in the German crown-witness regulation, the purpose of collaboration agreements is the attribution of criminal behavior to third parties and not merely the self-incrimination of the cooperator. ${ }^{1128}$ Although there is a consensual element in these exchanges, collaboration agreements can not be interpreted in the light of the res inter alios acta principle, since they necessarily give rise to triangular relationships in which law enforcement authorities partner with cooperating defendants to investigate and prosecute other accused.

Here a comparative perspective proves useful. In the German legal system, defendants have two different ways to proactively interact with public authorities and obtain benefits in investigation of serious offenses: the framework of negotiated judgments, established by $\mathbb{} 257 \mathrm{c}$ StPO, and the crown-witness regulation, set by $\mathbb{S} 46 \mathrm{~b} \mathrm{StGB}$. In the framework of negotiat-

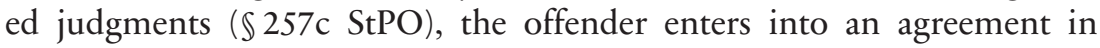
which he or she consents to confess to a crime in order to receive a milder

1125 Regarding the system of "quid-pro-quo" transactions set in the Organized Crime Act, see I.3.b.i.

1126 On this point, Stefanie Mehrens asserts that the assistance provided in the crown-witness regulation must relate to crimes committed by other agents and that are not identical to the acts practiced by the cooperator himself. See: Mehrens (n 11) 29.

1127 For an analysis of the similarities and differences between mechanisms for consensual resolution of criminal cases and leniency policies, see item IV.4.a.i.

1128 Buzari (n 12) 55. 
sentence. ${ }^{1129}$ The confession of the offender concerns his own acts and leads to an accelerated end to the criminal proceeding. ${ }^{1130}$

Brazilian law establishes some possibilities for the resolution of criminal proceedings through negotiated transactions, but only in cases related to minor offenses, as provided for under the 1995 Small Claims Act. ${ }^{1131}$ In the situations covered by the Small Claims Act, the Public Prosecution Office may offer the defendant a settlement that, once accepted, leads to a swift closure of the criminal investigation. Like the German framework of negotiated solutions $(\mathbb{S} 257 \mathrm{c}$ StPO), the negotiations between the parties under the Brazilian Small Claims Act relate only to the conduct of the defendant and do not reflect on investigations against other individuals.

This situation is clearly different from the negotiation of collaboration agreements. The Brazilian Organized Crime Act makes it clear that the rewarded collaboration regulation constitutes a new channel for the state to collect information and evidence against individuals who are not part of the collaboration agreements. ${ }^{1132}$ As occurs in the German crown-witness regulation ( $\$ 46 \mathrm{~b} \mathrm{StGB})$, the material obtained through collaboration agreements relates not only to the wrongful acts practiced by the cooperating defendant, but must be relevant to the prosecution of individuals who did not participate in the formation of the consensual relationship. ${ }^{1133}$

1129 Regarding the exchanges developed in the German practice of negotiated judgments, see item IV.2.b and IV.2.d.

1130 As Luis Greco notes, the acceleration of criminal proceedings is the main reason for the development of negotiated judgments in the Germany. See: Greco '„Fortgeleiteter Schmerz“ - Überlegungen zum Verhältnis von Prozessabsprache, Wahrheitsermittlung und Prozessstruktur' (n 26) 5.

1131 Outside the circumstances envisaged in the Small Claims Act, prosecutors and defendants have no powers, in Brazilian criminal procedure, to freely dispose of criminal cases through consensual arrangements. On this issue and the negotiation mechanisms introduced by the 1995 Small Claims Act, see item I.1.

1132 The Organized Crime Act specifically includes the rewarded collaboration regulation in a legislative catalog of special investigative measures, which also contains the interception of communications, the lifting of banking confidentiality and the employment of undercover agents. See Brazilian Organized Crime Act 2013, art 3.

1133 As expressly provided by German Criminal Code $(S t G B), \mathbb{} 46 \mathrm{~b}$ para 3 . See Buzari (n 12). André Buzari asserts that a confession related to the defendant's own acts is not enough to justify the granting of benefits under the crown-witness regulation, which demands assistance in the factual determination of wrongdoings commited by other agents (ibid 55-56). Stefanie Mehrens observes that the assistance provided by cooperating defendants resembles other 
It is senseless, therefore, to affirm that collaboration agreements do not affect third parties, just as it would be unthinkable to state that the interception of communications or the use of undercover agents do not affect the individuals investigated. As occurs in the German crown-witness regulation, the conclusion of an exchange under the Brazilian rewarded collaboration regulation depends on the existence of a third party that will be negatively affected by the arrangement negotiated by enforcement authorities and cooperating defendant. Without this third party, the triangular relationship set up by collaboration agreements cannot exist, and the use of the rewarded collaboration regulation becomes unfeasible.

b. Collaboration agreements as mechanism of consensual justice?

Disenchantment and reenchantment with truth-searching in criminal procedure

There is a widespread notion, in Brazilian scholarship and case-law, that collaboration agreements are - just like the negotiation mechanisms established by the Brazilian Small Claims Act - part of a new model of consensual justice, which has a different logic than, and distinct foundations from, standard criminal procedure. ${ }^{1134}$ According to this view, the conclusion of a collaboration agreement alters the defensive stance of the accused and accelerates the criminal proceeding, in a similar way to what occurs in the settlement possibilities provided for by the Brazilian Small Claims Act. ${ }^{1135}$ This correlation between collaboration agreements and the notion of a system of consensual criminal justice is inaccurate and misleading.

Leniency policies, such as the Brazilian rewarded collaboration regulation, are tools devised to maximize the state's capacity to control new forms of criminal structures in modern society, addressing the problems of

investigative tools used by enforcement authorities, such as the infiltration of agents in criminal organizations, insofar as it generates evidence regarding wrongdoings committed by third parties. See: Mehrens (n 11) 29.

1134 See item I.4.c. For further information: Aras (n 41) 271-274; Mendonça (n 36) 68.

1135 Vasconcellos, Colaboração Premiada No Processo Penal (n 36) 26. Also associating collaboration agreements with the negotiation mechanisms of the Small Claims Act, see Alves (n 43). 
impunity that arise in certain fields. ${ }^{1136}$ In view of the great challenges that exist in the investigation of organized crime, leniency policies arise as extraordinary devices for law enforcement authorities to detect offenses, identify offenders and collect relevant evidence for successful prosecutions. ${ }^{1137}$ Furthermore, they also have a preventive function, distorting the incentives for co-conspirators and creating instability inside criminal organizations. ${ }^{1138}$

None of these characteristics can be observed in the mechanisms of socalled consensual criminal justice, which are designed to resolve criminal proceedings in a more expedient manner and spare resources through negotiated arrangements between procedural participants. ${ }^{1139}$ Such mechanisms do not attempt to reduce impunity of sophisticated offenders or prevent the formation of criminal organizations, but rather aim at increasing the pace of criminal procedures and enabling effective use of the scarce resources of the criminal justice system. ${ }^{1140}$

While leniency policies seek to enhance the state's capacity to discover the facts of complex criminal conducts and improve deterrence of serious

1136 On this point, Ellen Schlüchter argues that the development of some types of wrongdoings in modern society - like those practiced by terrorists and criminal organizations - challenge the rule of law and require a strong answer from state authorities, authorizing the use of cooperating defendants. See: Schlüchter (n $495)$ 69-71. Also: Jeßberger, Kooperation Und Strafzumessung: Der Kronzeuge Im Deutschen Und Amerikanischen Strafrecht (n 1) 304.

1137 Heike Jung describes the German crown-witness regulation as an "extraordinary model to handle extraordinary situations” Jung (n 442) 42. Musco argues that the use of cooperating defendants aims to restore the state capacity to develop an effective answer in face of new and severe challenges posed by organized criminality. Musco (n 346) 38. On this point, see item III.2.a.

1138 Andreas Hoyer asserts that leniency policies transform the incentives in criminal organizations: instead of seeing each other as a means to obtain illegal profits, co-conspirators starts to see each other as a means to obtain immunity. See: Hoyer (n 442) 235. For a more detailed analysis of the preventive effect of leniency policies, see item III.2.b.

1139 According to Thaman, "'Consensual' procedural forms are part and parcel of criminal procedure reforms worldwide and are driven by the desire for procedural economy". See: Thaman (n 28) 952.

1140 In Germany, Julia Peters notes that the main argument for the development of negotiated judgments has been the scarcity of resources of the system of criminal justice. See: Peters (n 680) 17. On the same line, see the 2005 ruling of Federal Court of Justice, affirming the importance of consensual solutions to guarantee the proper functioning of the justice system. See BGH, Beschl. v. 3.3.2005 - GSSt 1/04 = BGHSt 50, 40, para 50-51. 
wrongdoings, mechanisms of consensual justice pursue different goals. ${ }^{1141}$ These mechanisms are not an expression of the state's commitment to search for truth, nor are they designed to maximize deterrence. In fact, they mitigate this commitment, since they abbreviate the official inquiry and allow for the rendering of a verdict before the full conclusion of the investigative phase. ${ }^{1142}$

These differences become even clearer when one analyzes the impacts that the consensual mechanisms have on criminal proceedings. In leniency policies, agreements with offenders lead to an expansion of the state's prosecution activity, either through the discovery of crimes hitherto unknown or through the gathering of new material regarding unclarified conduct. ${ }^{1143}$ Collaboration agreements, for instance, lead, through the collection of information and evidence previously unavailable, to the opening of new investigations or the enlargement of an existing one. In contrast, the use of mechanisms of consensual justice bring the criminal procedure to an abrupt close, limiting, rather than expanding, the investigative activities. ${ }^{1144}$ In Brazilian criminal law, for example, the consensual solutions designed by the Brazilian Small Claims Act allow the parties to swiftly wrap up criminal proceedings, replacing full factual investigations with negotiated arrangements. ${ }^{1145}$

Although collaboration agreements do establish relationships of voluntary exchanges between offenders and public authorities, they are clearly connected to the state's duty to search for the truth and to the ideal of maximizing deterrence, whereas mechanisms of consensual justice operate in accordance with the principles of simplicity, procedural economy, and celerity. ${ }^{1146}$ Therefore, it is not possible to understand collaboration agreements as a part of a new system of consensual justice. ${ }^{1147}$ Nor is it possible to draw a parallel between the rewarded collaboration regulation, set by

1141 On these diferences, see item IV.4.a.i.

1142 In Germany, different authors note the opposition between the state's commitment to search for truth and the enlargement of consensual mechanisms in criminal procedure. See Weßlau (n 25) 563-564; Hornle (n 963) 833.

1143 The sharing of evidence or information that already is in possession of the enforcement agencies does not authorize the granting of benefits. See: Frahm ( $\mathrm{n}$ 482) 54-55. On the issue of investigative achievements, see item I.3.d.

1144 Regarding the impact of negotiated judgments in German criminal procedure, see: Greco, "Fortgeleiteter Schmerz" - Überlegungen Zum Verhältnis von Prozessabsprache, Wahrheitsermittlung Und Prozessstruktur’ (n 26) 5.

1145 See item I.1.

1146 See item IV.4.a.i.

1147 In the same vein: Canotilho and Brandão (n 36) 22. 
the Organized Crime Act, and mechanisms for consensual resolutions of criminal cases, such as the ones provided by the Brazilian Small Claims Act. Although in both situations there are rooms for exchanges between law enforcement authorities and defendants, these negotiation forums have completely different - if not opposite - foundations, purposes, and consequences. ${ }^{1148}$

The prevailing view in Brazilian law, which associates collaboration agreements with a system of consensual justice, ignores the conceptual difference between fact-finding tools, used to investigate suspected conducts, and mechanisms of consensual resolution of criminal cases, that provide for a negotiated closure of investigations. At this point, the use of the comparative analysis can be enlightening.

In the German legal system, such a distinction is very clear in the separation between the crown-witness regulation, established by $\$ 46 \mathrm{~b}$ StGB, and the framework of negotiated solutions, set by $\$ 257$ c StPO. Although both provisions carry consensual elements and share some common features, they fulfill very different purposes: while the first empowers law enforcement authorities with a new investigative device to counterbalance the techniques of criminal organizations, in an inverted reading of the principle of equality of arms, the latter devises a mechanism for acceleration of criminal proceedings, linked with the principle of procedural economy. ${ }^{1149}$ Whereas the crown-witness regulation $\$ 46 \mathrm{~b}$ StGB emerges as a tool for maximizing the state's prosecution against sophisticated criminal structures in the context of investigative emergencies, the negotiated judgments of $\$ 257 \mathrm{c}$ StPO are mechanisms to provide a quick consensual end to criminal investigations, maintaining the functional capacity of the justice system.

Even in the United States, where procedural participants dispose of a very wide room for inter-party negotiations and may create different types of consensual solutions, this distinction is made through the concept of a "cooperation agreement", as opposed to the traditional concept of "plea agreement". ${ }^{1150}$ Plea agreements are procedural mechanisms through which the defendant and prosecutor dispose of the case, and which nor-

1148 See item IV.4.a.ii.

1149 See item IV.4.a.i.

1150 According to Strang: "By comparison to traditional plea agreements, cooperation agreements are investigatory tools. The cooperating defendant's admission of personal guilt is not the primary goal; the point is to use this cooperating defendant, proactively or historically, to develop evidence to prosecute other individuals". See: Robert R Strang, 'Plea Bargaining, Cooperation Agree- 
mally contain a guilty plea of the defendant in exchange for a lighter sentence. ${ }^{1151}$ Cooperation agreements, in contrast, are primarily instruments to investigate crimes committed by other individuals, in which the admission of guilt by the cooperating defendant is not an end in itself, but rather a means to prosecute and punish co-conspirators. ${ }^{1152}$

It is not possible, therefore, to understand the Brazilian rewarded collaboration regulation as part of a new system of consensual justice, where the solution of criminal proceedings stems not from a thorough factual investigation, but from the consent of the procedural participants. ${ }^{1153}$ Unlike mechanisms for the consensual resolution of criminal cases, collaboration agreements do not create an alternative route to a faster end of the proceeding. They actually operate in the opposite manner, through the creation of a cooperative relationship between law enforcement authorities and offenders that reinforces the state's commitment to discover criminal conduct, gather the relevant evidence and establish individual liability through an accurate fact-finding process.

In view of the evidentiary challenges present in the prosecution of organized crime, the rewarded collaboration regulation offers a solution to deepen, not to curtail, the state's efforts to determine how relevant events really happened. While consensual mechanisms thrive in scenarios of dis-

ments and Immunity Orders.'(2014) 155th International Training Course Visiting Experts' Papers, $30<$ https://www.semanticscholar.org/paper/PLEA-BARG AINING-\%2C-COOPERATION-AGREEMENTS-\%2C-AND-Strang/04ee8da12 9e50f2cf4f8ce3cdc4df46bc3cabfa3 > accessed 14 September 2019.

1151 Langer (n 28) 35.

1152 Even though they are generally accompanied by a guilty plea, cooperation agreements have characteristics that clearly distinguish them from the more simple practice of plea bargaining. Ian Weinsten highlights "the unique problems associated with cooperation, in addition to those of ordinary plea bargains". See: Weinstein (n 3) 567. According to Malvina Halberstram: “Agreements by the prosecutor to lower or dismiss the charges against a defendant or to make sentencing recommendations in exchange for something other than a guilty plea by the defendant, such as the defendant's agreeing to testify against someone else or to provide the government with vital information, although usually accompanied by guilty pleas, involve different considerations (...)". See: Halberstam (n 981) 4.

1153 In the opposite direction, see the ruling of the Brazilian Federal Supreme Court that understood that the rewarded collaboration regulation forged a "new model of criminal justice that favors the expansion of the space of consensus and the adoption, in the definition of controversies arising from criminal offenses, of solutions based on the consent of the agents who are parties of the criminal procedural.” See STF, PET 7074 [2017] (Celso de Mello J). 
enchantment with the objective of truth finding, collaboration agreements promise to detect concealed conduct and shed light on obscure situations, in a process of re-enchantment with the old ideal of seeking truth in criminal procedure. ${ }^{1154}$

c. Collaboration agreements as public-private partnerships and the privatization of official investigations

The Federal Supreme Court's position that collaboration agreements are pure bilateral contracts offers a very shortsighted perspective on the complexities and difficulties that arise from the use of leniency policies to overcome investigative emergencies. Collaboration agreements represent the start of a new momentum in the official inquiry, expanding the fact-finding efforts through the establishment of a stable and durable partnership between law enforcement authorities and offenders directed at holding other accused accountable.

In jurisdictions where criminal process is understood as an official investigation, such partnerships represent the active sharing with private agents of activities that for a long time have been understood as a monopoly of public authorities. ${ }^{1155}$ Through the establishment of cooperative bonds with private agents, ${ }^{1156}$ enforcement authorities seek to overcome the serious obstacles that exist in the prosecution of sophisticated criminal struc-

1154 According to Bernd Schunemann, the German practice of negotiated judgments was developed in a context of disenchantment with the objective of search for truth, particularly in cases of monster proceedings. See: Schünemann, 'Die Verständigung Im Strafprozeß - Wunderwaffe Oder Bankrotterklärung Der Verteidigung?' (n 27) 1898. Regarding the process of "re-enchantment" with the ideal of search for truth, see item IV.4.a.ii.

1155 For a strong critic of this model of enforcement through "Public Private Partnership" between enforcement authorities and corporations in the field of economic crimes, see: Hefendehl, 'Außerstrafrechtliche Und Strafrechtliche Instrumentarien Zur Eindämmung Der Wirtschaftskriminalität' (n 12) 846-847. Analyzing this evolution in the German context, Klaus Malek criticizes fiercely the privatization of activities of law enforcement and describes this process as the "americanization of German criminal procedure". See: Malek, "Abschied von Der Wahrheitssuche' (n 470) 561.

1156 These partnerships between enforcement agencies and private agents can also arise from whistleblowing mechanisms and the so-called "internal investigations”. Regarding the problems generated by the model of internal investigations, see: Greco and Caracas (n 23). On the issue of whistleblowing, see: Martín (n 23) 69-92. 
tures, like corruption networks and business cartels. ${ }^{1157}$ The prosecution of criminal cases and the investigation of serious wrongdoing cease to be performed exclusively by law enforcement authorities and start to be carried out through partial delegation to offenders involved in serious crimes, who are remunerated on the basis of penalty reductions. In this scenario, the principal task of law enforcement authorities is not to conduct an autonomous search for evidence, but rather to construct a system of incentives for offenders to abandon the criminal organization and cooperate against former accomplices. ${ }^{1158}$

For the accused, the conclusion of a collaboration agreement represents a complete change of role in the criminal process. ${ }^{1159}$ Instead of adopting a defensive stance and limiting the access of law enforcement authorities to evidence, they will seek to share the necessary material to secure leniency benefits. ${ }^{1160}$ The beneficiary ceases to be a passive object of the investigation and becomes a longa manus of law enforcement authorities, whose duty is to aid in obtaining evidence to convict other offenders. ${ }^{1161}$

From this perspective, the relationships developed under the Brazilian rewarded collaboration regulation should be understood, rather than as simple bilateral transactions, as complex public-private partnerships, in which state organs and private agents establish a long-lasting cooperative bond to jointly develop specific activities and achieve defined objectives, sharing the costs, benefits and risks involved in this endeavor. ${ }^{1162}$ Like other public-private partnerships, collaboration agreements lead to a partial

1157 On the structural obstacles to the effective prosecution of these crimes, see section II.3.

1158 The introduction of leniency policies is a game changer for the strategy and operation of enforcement agencies. On this point, see item III.3.c.

1159 According to Jeßberger, leniency policies transform accused in active agents of criminal prosecution See: Jeßberger (n 1) 27-30.

1160 Regarding the risks of over and under-cooperation, see item III.3.a. See also: Spagnolo (n 30) 295; Forrester and Berghe (n 566) 251-252.

1161 Analyzing the prosecution of corporate crimes in the U.S., Harry First describes "an important, if gradual, change in the role of the public corporation in the criminal process, from potential criminal target to branch office of the prosecutor whose role it is to partner with prosecutors in investigating and prosecuting business crimes". See: First (n 609) 97.

1162 Public-private partnerships (PPP) can be defined as the "cooperation between public and private actors with a durable character in which actors develop mutual products and/or services and in which risk, costs, and benefits are shared". See: Erik-Hans Klijn; and Geert R Teisman., 'Institutional and strategic barriers to public-private partnership: an analysis of Dutch cases' (2003) 23 Public Money and Management 137. For a good description of these partnerships in 
privatization of state functions, transferring to offenders activities in the criminal procedure that were formerly performed by official bodies.

This process of privatization has a utilitarian nature and is founded strictly on practical reasons: the cooperation of private agents (the offenders) shall assist law enforcement in controlling certain forms of criminality and preventing impunity in situations where traditional investigative tools are ineffective. ${ }^{1163}$ As in other public-private partnerships, the partial privatization of state functions is carried out with the expectation of carrying out a specific activity in a more efficient manner and with greater quality. In the realm of leniency policies, the expectation is twofold: first, collaboration agreements should lead to a more extensive collection of evidence and information, helping to identify and punish individuals responsible for serious crimes; ${ }^{1164}$ second, they should enhance instability and instigate conflicts within criminal organizations, restricting the conditions for the adoption of criminal behavior. ${ }^{1165}$

On the other hand, the establishment of public-private partnerships within the apparatus of state prosecution may create several problems, which arise from the principal-agent relationships engendered by leniency policies. ${ }^{1166}$ These partnerships are especially problematic when the activities carried out by private agents have a complex nature and unpredictable outcomes, because in such situations agents have incentives to cut costs and reduce their efforts, even if this leads to a lower quality of service. ${ }^{1167}$ Given the different goals pursued by each of the contracting parties and the asymmetry of information between them, private actors can develop various strategies to maximize their interests through partial and selective cooperation with public authorities. ${ }^{1168}$ Sophisticated agents may even ex-

the prosecution of international corruption, see: Centonze (n 1). Critically, in the field of corporate crimes: Hefendehl, 'Außerstrafrechtliche Und Strafrechtliche Instrumentarien Zur Eindämmung Der Wirtschaftskriminalität' (n 12) 846-847.

1163 On the utilitarian nature of these mechanisms, see item III.2.

1164 See item III.2.a.

1165 See item III.2.b.

1166 According to Centonze, "the state embodies the role of the principal enlisting private organizations (its agents) to perform activities to prevent business crimes". See: Centonze (n 1) 44. On this issue, see item III.3.

1167 Oliver Hart, Andrei Shleifer and Robert W Vishny, 'The Proper Scope of Government: Theory and an Application to Prisons' (1997) The Quarterly Journal of Economics 1127,1148-1159.

1168 See item III.3.a and III.3.b. 
plore the association with law enforcement authorities to reinforce criminal strategies, "gaming" the leniency system. ${ }^{1169}$

In this context, it is clear that collaboration agreements engender very different relationships between defendants and law enforcement authorities than mechanisms of consensual resolution of criminal cases, consequently raising diverse challenges and problems. Collaboration agreements are, like other public-private partnerships, risky joint ventures. In contrast to consensual mechanisms, in which a negotiated arrangement settles the case with some degree of certainty for the parties, collaboration agreements create complex and durable relationships, whose outcomes depend on different variables and will only be known after a lengthy period. ${ }^{1170}$ Allegations made by the beneficiary of the agreement must be confirmed by other evidence and will undergo multiple tests of legality and accuracy before reaching the expected outcome: the successful prosecution of other offenders. ${ }^{1171}$

Therefore, the position that collaboration agreements are purely bilateral arrangements underestimates the complexities, expectations and risks that arise from the establishment of durable cooperation bonds with offenders within the apparatus of state prosecution. The understanding that collaboration agreements are public-private partnerships directed at establishing the criminal liability of third parties offers a better perspective to correctly address the important questions raised by the Brazilian rewarded collaboration regulation.

1169 See item III.3.d.

1170 Examining the German crown-witness regulation, Klaus Malek observes that the regulation does not create "do ut des" relationships between public authorities and cooperating defendants. See: Malek, 'Die neue Kronzeugenregelung und ihre Auswirkungen auf die Praxis der Strafverteidigung' (n 480) 203. On this issue, see III.3.b.

1171 Florian Jeßberger notes the uncertainties and risks faced by the cooperating defendant. See Jeßberger, 'Nulla Poena Quamvis in Culpa: Ammerkungen Zur Kronzeugenregelung in $₫ 46 S t G B$ ' (n 2) 1162. According to David Moss, due to the inherent risks and obstacles of complex criminal investigations and the various challenges that must be collectively faced by cooperators and public authorities, the establishment of bonds of a personal nature appears as a recurring feature of these investigative joint ventures. See: Moss (n 1103) 309. 
d. Is there a Brazilian system of plea bargaining? Legal transplants, legal translations and legal counterfeits

The inventive practice of collaboration agreements wrought significant innovations and created a detachment between the text of the Organized Crime Act and the "law in action" carried out before courts. ${ }^{1172}$ The examination of various agreements reveals that legal practitioners drew on the negotiation forum designed by the rewarded collaboration regulation to develop a wide and flexible system of transactions, which allowed the parties to negotiate tailor-made and complex consensual arrangements. The U.S. model of plea bargaining has repeatedly been used as a role model to justify these consensual innovations and validate the partial abandonment of traditional principles of Brazilian criminal procedure. ${ }^{1173}$ The term "plea agreement" is nowadays often used by public officials and legal scholars to refer to the recent collaboration agreements concluded between the Brazilian Public Prosecution Office and cooperators, implying that the enactment of the Organized Crime Act represented some type of importation of this American legal institution. ${ }^{1174}$

The debate on the transmission of legal practices between countries is extensive, commonly under the concept of "legal transplants". ${ }^{1175}$ In the last decades, a vast literature has been developed on the subject ${ }^{1176}$ point-

1172 See item I.4.a.

1173 See item I.4.c.

1174 See: Moro (n 31) 160; Armando Castro and Shaz Ansari, 'Contextual "Readiness" for Institutional Work. A Study of the Fight Against Corruption in Brazil' (n 115) 351-365; De Almeida and Zagaris (n 332) 89; Brian Winter, 'Brazil's never-ending corruption crisis: why radical transparency is the only fix' (2017) 96 Foreign Affairs 87, 90; Rodrigo Janot, 'Rodrigo Janot: the lessons of Car Wash' (2017) Americas Quarterly, <https://www.americasquarterly.org/ content/lessons-car-wash>, accessed 23 July 2019.

1175 Alan Watson, Legal transplants: an approach to comparative law (Univesity of Georgia Press 1974); Alan Watson, 'From legal transplants to legal formats' (1995) 43 The American Journal of Comparative Law, 469; William Ewald, 'Comparative jurisprudence (II): the logic of legal transplants' (1995) 43 The American Journal of Comparative Law 489; Nuno Garoupa and Anthony Ogus, 'A Strategic Interpretation of Legal Transplants' (2006) 35 Journal of Legal Studies 339.

1176 For an analysis of the conception and evolution of the concept of "legal transplant", see: John W Cairns, 'Watson, Walton, and the History of Legal Transplants' (2013) 41 The Georgia Journal of International and Comparative Law 637. 
ing out its advantages, ${ }^{1177}$ as well as highlighting its risks and limits. ${ }^{1178}$ The concept of "legal transplants" is now widely used to analyze developments in several fields, such as private law, ${ }^{1179}$ environmental law, ${ }^{1180}$ intellectual property ${ }^{1181}$ and legislative process. ${ }^{1182}$

In the field of criminal law, a point that stands out is the recent dissemination in several countries, even in those integrated into the continental tradition, of consensual mechanisms in criminal procedure, which have traditionally been associated with the U.S. criminal justice system. ${ }^{1183}$ Over the last decades, different countries have adopted mechanisms that allow procedural participants to resolve criminal cases through consensual arrangements that resemble to a greater or lesser extent the U.S. system of plea bargaining. ${ }^{1184}$ In this context, it is worth asking if the Brazilian Criminal Organization Act has really established a mechanism equivalent to the American model of plea bargaining, since that would entail profound impacts on the Brazilian justice system.

Once it is established that collaboration agreements do not constitute a consensual mechanism for prosecutors and defendants to resolve criminal

1177 See, e.g.: Rainer Kulms, 'Optimistic normativism after two decades of legal transplants and autonomous developments' in Christa Jessel-Holst, Rainer Kulms and Alexander Trunk (eds), Private Law in Eastern Europe: Autonomous Developments or Legal Transplants?(Mohr Siebeck 2010) 7-14; Loukas Mistelis, 'Regulatory Aspects: Globalization, Harmonization, Legal Transplants, and Law Reform - Some Fundamental Observations' (2000) 34 International Lawyer 1055 .

1178 See: Pierre Legrand, 'The impossibility of "legal transplants"' (1997) 4 Maastricht Journal of European and Comparative Law 111; Gunther Teubner, 'Legal Irritants: Good Faith in British Law or How Unifying Law Ends Up in New Divergencies' (2003) 61 The Modern Law Review 11.

1179 Kulms (n 1177).

1180 Jonathan B Wiener, 'Something Borrowed for Something Blue: Legal Transplants and the Evolution of Global Environmental Law' (2001) 27 Ecology Law Quarterly 1295.

1181 Paul Edward Geller, 'Legal Transplants in International Copyright: Some Problemas of Method' (1994) 13 UCLA Pacific Basin Law Journal 199.

1182 Anders Fogelklou, “'The Regional Ombudsman as a Western (Swedish) Legal Transplant: ", : Experiences from the Legislative Process in St. Petersburg' (2003) 13, Transnational Law and Contemporary Problems 537.

1183 As noted by Schunemman: Schünemann, 'Zur Kritik Des Amerikanischen Strafprozessmodells' (n 25) 569-571.

1184 For a thorough analysis of the introduction of mechanisms similar to the U.S. system of plea bargaining in jurisdictions of continental tradition, particularly in Germany, Italy, Argentina and France, see: Langer (n 28). 
cases, ${ }^{1185}$ representing instead public-private partnerships directed at investigating and prosecuting third parties, ${ }^{1186}$ it becomes clear that the answer to this question must be in the negative.

Plea agreements are mechanisms of consensual disposal of criminal cases, which allow procedural participants to terminate criminal proceedings through a negotiated arrangement that normally contains the acknowledgement of the defendant's guilt. ${ }^{1187}$ The understanding, enshrined in U.S. justice, that criminal proceedings represent a dispute between prosecution and defense, grants wide discretionary powers for the parties to dispose of the case: prosecutors are basically free to decide on which criminal charges should be presented, ${ }^{1188}$ and accused can accept the charges through a guilty plea. ${ }^{1189}$ Regarding charging decisions, judicial bodies clearly play a passive role and parties have, within these boundaries, broad autonomy to resolve the case through consensual arrangements. ${ }^{1190}$

None of these characteristics can be found in the Brazilian rewarded collaboration regulation. According to the text of the Organized Crime Act, the conclusion of a collaboration agreement does not lead to the interruption or abbreviation of the proceeding against the cooperating defendant, nor does it generate any of the effects associated with plea agreements in the American system. ${ }^{1191}$ The cooperator shall be convicted, and the sentence determined, only after a full inquiry of the facts and an independent determination of criminal liability. The cooperating defendant's statements alone are not sufficient to substantiate any conviction, even his

1185 See item V.3.b.

1186 See section V.3.c.

1187 According to Alschuler: "plea bargaining consists of the exchange of official concessions for a defendant's act of self conviction". See: Alschuler (n 42) 3 .

1188 Recognizing the very broad space of action held by American prosecutors, Dominik Brodowsky notes that these wider powers are understood as an expression of a political function. See: Brodowski (n 24) 742.

1189 Bernd Schünemman observes that the concept of "guilty plea", which allows defendants to accept the criminal charges presented by the prosecutor, is the foundation for the development of the practice of plea bargaining. See: Schünemann, 'Zur Kritik Des Amerikanischen Strafprozessmodells' (n 25) 564-565.

1190 Notwithstanding the autonomy of the parties, William T. Pizzi acknowledges that the judge retains broad powers to determine the sentence, describing this situation "an inquisitorial soul in an adversarial body". See: William Pizzi, 'Sentencing in the US: an inquisitorial soul in an adversarial body?' in John Jackson, Maximo Langer and Peter Tillers (eds) Crime, procedure and evidence in a comparative and international context (Hart Publishing 2008) 65-79.

1191 Brazilian Organized Crime Act 2013, art 4. 
own. ${ }^{1192} \mathrm{~A}$ confession under a collaboration agreement does not mean a "break in the chain of events" of the criminal proceeding, representing rather just another link - often the first one - in this chain. ${ }^{1193}$

In the Brazilian rewarded collaboration regulation, as occurs in the German crown-witness regulation, the benefits granted to cooperating defendants stem from their contribution to investigations against third parties in situations of investigative emergencies. ${ }^{1194}$ Collaboration agreements represent, in Brazilian law, investigative devices for the detection and deterrence of serious crimes, connected to the state's commitment to search for truth and to an inverted reading of the principle of equality of arms. ${ }^{1195}$ They engender a partial privatization of investigative and prosecutorial activities, transforming defendants into a longa manus of law enforcement authorities, responsible for collecting information and evidence concerning the acts of other accused. ${ }^{1196}$

From this perspective, to assert an equivalence between collaboration agreements, established in the Brazilian Organized Crime Act, and the American concept of plea agreements reveals not only a terminological mistake, but also a translation decision that, if disseminated, may have a profound impact on the Brazilian justice system. In the structure of meanings and practices associated with the U.S. plea bargaining system, prosecutors and accused are largely free to dispose of the criminal process through consensual arrangements. ${ }^{1197}$ This broad power of the parties to dispose of the criminal procedure is a completely foreign body to the Brazilian legal system. ${ }^{1198}$ Although the provisions of the Organized Crime Act have increased the field of action of law enforcement authorities and defendants within criminal proceedings, they have not created a wide room for interparty negotiations and do not permit the parties to resolve criminal cases through agreements. ${ }^{1199}$

1192 Brazilian Organized Crime Act 2013, art 4, $\mathbb{1 6}$.

1193 In its ruling on Tollett v. Henderson, 411 U.S. 258 (1973), the U.S. Supreme Court affirmed that "a guilty plea represents a break in the chain of events which has preceded it in the criminal process". On this issue, see item V.2.b.

1194 See item V.2.a. For a more detailed analysis of the the German crown-witness regulation, see item IV.3.c.

1195 See item V.3.a.

1196 See item V.3.c.

1197 Langer (n 28) 36.

1198 On the limited capacity of parties to dispose of criminal cases in Brazilian criminal justice, see item I.1.

1199 Marcelo Cavali notes that the Brazilian practice of collaboration agreements forged arrangements similar to the U.S. plea bargain model, but rejects this de- 
At this point, it is important to note that the circulation of legal institutions between different countries occurs by a complex process with various dimensions. ${ }^{1200}$ Ideas and practices imported from other countries acquire their own meaning in the new environment and lead to results that are different from those achieved in their original context. ${ }^{1201}$ This assimilation process leads not only to adaptation of the foreign concepts but also to the reconstruction of the national system in order to receive the new rules. ${ }^{1202}$ In this process, the decisions made by the actors directly involved in the dynamics of the reforms, who act as translators responsible for integrating the imported concepts into the national law, are of extreme relevance. ${ }^{1203}$ Such translation decisions are not neutral and reflect power struggles between various groups, which concern not only abstract matters of terminology, but also define the social practices that will implement the structure of meanings assimilated by the domestic legal system. ${ }^{1204}$

The rewarded collaboration regulation was enacted as a device for the collection of information and evidence in situations of investigative emergencies, through the development of public-private partnerships within the traditional structure of Brazilian criminal procedure. The practice of collaboration agreements has transformed the narrow and limited negotiation forum introduced by the Organized Crime Act into a free bargaining zone, where almost any type of transaction is possible. ${ }^{1205}$ The proposed equivalence between collaboration agreements and plea bargains seeks to

velopment because of the lack of a solid legal basis. See: Cavali (n 36) 262 and 274. In the same vein: Canotilho and Brandão (n 36) 22. In the opposite direction, defending the existence of wide negotiation forum in the rewarded collaboration regulation, see: Mendonça (n 36).

1200 Langer (n 28) 30-35.

1201 Mirjan Damaška, 'The Uncertain Fate of Evidentiary Transplants: Anglo-American and Continental Experiments' (1997) 45 American Journal of Comparative Law 839, 840.

1202 In Gunther Teubner's description, legal institutions transposed from one jurisdiction to another "are not transformed from something alien into something familiar, not adapted to a new cultural context, rather they will unleash an evolutionary dynamic in which the external rule's meaning will be reconstructed, and the internal context will undergo fundamental change”. See: Teubner (n 1179) 12.

1203 Langer (n 28) 32-33.

1204 ibid 34-35.

1205 On Item VI.2.b, it is argued that the granting of benefits in collaboration agreements must abide by the numerus clausus principle, respecting the limits set by the Brazilian Organized Crime Act. 
legitimize this new reality and portray it as a reasonable and acceptable scenario.

However, in view of the striking differences between collaboration agreements, provided for in the Brazilian Organized Crime Act, and the U.S. plea bargaining system, it is no exaggeration to classify this comparison as a case of "legal counterfeit", where the distorted reproduction of foreign legal practices is used as a rhetorical recourse to justify certain understandings and to immunize them from criticism. ${ }^{1206}$ The objective of this deceptive comparison is quite straightforward: to lend some type of legitimacy to a system of accelerated conviction and sentencing operated by law enforcement authorities without any effective judicial control. ${ }^{1207}$

Curiously, in the process of emulating the worst aspects of the American criminal justice system, Brazilian courts have developed a devotion to consensual arrangements that appears unusual even by U.S. standards. This can be seen on the analysis of the binding effect of collaboration agreements, a subject that will be discussed in the following section. ${ }^{1208}$

\section{e. The contractual redesign of Brazilian criminal law}

The rewarded collaboration regulation established a simple exchange between individuals and public authorities: in return for their assistance in the prosecution of third parties, cooperating defendants may receive full immunity, the reduction of imprisonment penalties or their replacement with a sanction of rights' restriction. In the practice of collaboration agreements, however, legal practitioners have used the negotiation forum of the rewarded collaboration regulation to design innovative consensual arrangements that are much more complex than the transactions foreseen in

1206 As observed by Luís Greco and Alaor Leite regarding the use of the theory of dominion of the act ("Tatherrschaft") in an important ruling of the Brazilian Federal Supreme Court. According to the authors, "the ruling represents, from the perspective of comparative law, an interesting case of a foreign theory, allegedly internalized (the so-called legal transplant), that came out as nothing more than a sham (a legal counterfeit)". See: Greco and Leite (n 17) 292.

1207 Criticizing the American system of plea bargaining, Bernd Schunemman asserts that "behind the shiny facade of the ideal of party-process, in more than 90\% of the cases something very different occurs: a swift condemnation implemented by the investigative authorities without genuine judicial supervision". See: Schünemann, 'Zur Kritik Des Amerikanischen Strafprozessmodells' (n 25) 556.

1208 See particularly item V.4.a. 
the Organized Crime Act. Instead of following the model of simple exchanges established in the statutory text, cooperating defendants and public prosecutors have drafted long and sophisticated agreements, with dozens of clauses and annexes, devising customized solutions to meet the particularities of each different situation and regulating a wide array of matters that go far beyond the textual provisions.

One agreement, for instance, designed a success fee for the cooperator, determining that two percent of the value of the recovered assets would be written-off his compensation fine. ${ }^{1209}$ Another agreement established for the cooperator a right to "penalty equalization": according to the clause, if another defendant concluded a collaboration agreement regarding the same investigated facts with a lower penalty, the cooperator's punishment would be equalized, preventing the cooperator from having a less favorable situation. ${ }^{1210} \mathrm{~A}$ third established the duty of the cooperator to provide studies, analyses and technical advice for public authorities for a period of thirty years. ${ }^{1211}$ Collaboration agreements precisely regulated very specific issues, such as when and to where a cooperator could travel, in which professional fields another cooperating defendant was authorized to work and even which individuals had the right to visit cooperators during their period of imprisonment. One collaboration agreement even authorized the defendant to leave his residence, for six hours, on the date of celebration of Father's Day in the school of his children. ${ }^{1212}$

Scrutiny of collaboration agreements concluded over recent years unveils a flexible and comprehensive system of transactions, where defendants and public prosecutors are largely free to consensually regulate multiple aspects of criminal cases, negotiating in a similar manner to contracting parties in private law. Within this system, the consequences of the commitment of a crime are not defined by the legislation, being rather determined through negotiated arrangements with the Public Prosecution Office. The Brazilian Federal Supreme Court has endorsed this system of wide contractual freedom, affirming that the parties' transactions are not limited by the statutory boundaries. ${ }^{1213}$

1209 See STF, Collaboration Agreement of A.Y. [2014], clause 7 para 4.

1210 See STF, Collaboration Agreement of F.M.S. [2017], clause 5 para 4-5.

1211 See STF, Collaboration Agreement of L.B.F. [2017], clause 4, para II, item "g".

1212 For a description of these and other innovations brought by the negotiation of tailor-made arrangements, see item I.4.b.

1213 See STF, HC 127483 [2015] and STF, INQ 4405 AgR [2018]. 
This understanding is deeply flawed and has widespread perverse effects on the justice system. In the private sphere, contractual freedom is understood as the embodiment of personal autonomy and self-determination, conferring wide discretion for agents to change, through consensual arrangements, their patrimony. ${ }^{1214}$ Thus, in traditional contract law, individuals are free to create new forms of transactions, as long as some basic guidelines are respected. ${ }^{1215}$

Criminal proceedings, however, are obviously not simple disputes between two parties, since the result of a criminal process has far-reaching implications for society, affecting a wide spectrum of interests that go well beyond the legal sphere of the procedural participants. ${ }^{1216}$ The seriousness of criminal punishment, which limits the liberty and jeopardizes the social existence of a person, does not permit the imposition of imprisonment penalties based solely on individual consent. ${ }^{1217}$ Therefore, the determination of a solid factual basis, through an impartial production of evidence in a public and transparent process, is essential to establish individual guilt and justify a criminal sentence. ${ }^{1218}$

Therefore, although the rewarded collaboration regulation does open a legitimate space for consensual arrangements, this negotiation forum does not represent a full acknowledgement of private autonomy and contractu-

1214 Describing the traditional view of contract law, Florian Rödl asserts that under this approach "contracting means exercising one's freedom, and the law, generally made to enable and to protect human freedom, makes such exercises effective. That is why contractual autonomy is at the core of this understanding of contract law”. See: Florian Rödl, 'Contractual Freedom, Contractual Justice, and Contract Law (Theory)' (2013) 76 Law and contemporary problems 57, 59. See also: Marcelo Cama Proença Fernandes, Contratos: Eficácia e Relatividade Nas Coligações Contratuais (Saraiva 2014) 37.

1215 In this sense, it is recurrent to note that the principle of freedom of contract implies "the freedom to choose the content of the contract as well as the form". See: Bénédicte Fauvarque-Cosson; Denis Mazeaud (eds.), European contract law: materials for a common frame of reference: terminology, guiding principles, model rules (Sellier. European Law Publishers 2008) 423. According to the authors, "Freedom of contract is therefore understood in this sense as a freedom of form" (424).

1216 Noting that criminal procedure affects several interests, and not only those of the procedural participants, see: Tatjana Hörnle, "Justice and Fairness": Ein Modell Auch Für Das Strafverfahren?' (2004) 35 Rechtstheorie 175,194. Also: Weigend, 'Unverzichtbares Im Strafverfahrensrecht' (n 23) 304.

1217 Schünemann, 'Zur Kritik Des Amerikanischen Strafprozessmodells' (n 25) 187.

1218 Greco, Strafprozesstheorie Und Materielle Rechtskraft (n 668) 183. 
al freedom in the realm of criminal procedure. For the accused, a collaboration agreement represents, above all, a mechanism to avoid or mitigate a harsh intervention in their individual freedom. ${ }^{1219}$ The offender's consent in such situations can be only partial: it affects a small part of the proceeding and is granted in a context where the other alternative is the natural continuation of the process, with the constant threat of more severe penalties. ${ }^{1220}$ For law enforcement authorities, collaboration agreements represent a a punctual mitigations of the principle of compulsory prosecution, in order to increase the state's capacity to properly prosecute and punish co-conspirators, bringing the overall level of punishment closer to the ideal established in legislation. ${ }^{1221}$

Under these circumstances, it becomes clear that collaboration agreements must be negotiated within the statutory limits of the Organized Crime Act, since procedural participants lack, beyond these limits, the legal capacity to develop new forms of consensual solutions. ${ }^{1222}$ This restrictive view of the negotiation forum of the rewarded collaboration regulation is necessary to preserve the myriad of other interests enshrined in criminal law and protected by criminal procedure. To understand otherwise, envisioning a wide contractual freedom in the context of the rewarded collaboration regulation, means to allow law enforcement authorities and defendants to freely dispose, in each case, of the most essential values of society. Such an understanding transforms the justice system into a flea market, where every type of transaction is possible and contractual creativity gives rise to increasingly innovative provisions that are completely disconnected from substantive criminal law. ${ }^{1223}$

Furthermore, this virtually unrestrained contractual freedom also erodes, in the long term, the effectiveness of the rewarded collaboration regulation. The rewarded collaboration regulation, like other leniency policies, leads to a partial or total amnesty for offenders who should otherwise be punished. ${ }^{1224}$ The purpose of this mitigation is to strengthen the state's

1219 Luis Greco notes that, within criminal procedure, the defendant's consent will always be announced in a structure of coercion ("Zwangstruktur") (ibid 270).

1220 Hassemer, 'Konsens Im Strafprozeß’ (n 699) 187.

1221 See item V.2.a. Affirming this position in relation to the German crown-witness regulation, see: Hoyer (n 442) 240; Jung (n 442) 41-42.

1222 On this point, see item I.1.

1223 Arguing that the negotiations developed under the rewarded collaboration regulation must respect the principle of numerus clausus, see section VI.2.b.

1224 This is the "dark side" of leniency policies, as mentioned in: Acconcia and others (n 29) 1118. 
capacity for prosecution in face of new and challenging criminal realities, whether by facilitating the obtainment of evidence or by creating obstacles to the commitment of new crimes. ${ }^{1225}$ Nevertheless, the reduction of penalties, if excessive or unjustified, can lead to outcomes that are exactly the opposite to those originally expected, creating scenarios of unjustified impunity. ${ }^{1226}$ The positive and negative effects of leniency policies must, thus, be balanced through a delicate structure of incentives, designed to maximize the gains and minimize the losses generated by the granting of benefits to offenders. ${ }^{1227}$

In the rewarded collaboration regulation, this balance is defined, firstly, by the provisions of the Organized Crime Act, which set forth the situations in which collaboration agreements can be used, the benefits that can be granted and the individuals who can benefit from them. The broadening of the negotiation room beyond the statutory boundaries, as has occurred in the practice of collaboration agreements, undermines the structure of incentives designed by the legislator and enables offenders to end up in situations much more advantageous than those established in the Organized Crime Act. The boom in the adverse amnesty effect is clear and undeniable.

The adoption of a flexible regime for the negotiation of collaboration agreements clearly facilitates the resolution of cases by law enforcement authorities, as it allows them to constantly devise new incentives for cooperation. The development - through consensual agreements rather than by statute - of a generous range of leniency benefits tends to lead to a scenario where an increase in the number of solved cases is accompanied by a reduction in the deterrent effects of criminal law. ${ }^{1228}$ However, the primary purpose of leniency policies is not to simplify the investigative activities of law enforcement authorities, but rather to maximize detection and deter-

1225 For a more detailed analysis of these two expected effects of leniency policies, see item II.2.

1226 See item III.3.b.

1227 Affirming the need for limits in the granting of leniency benefits, see: Spagnolo, 'Leniency and whistleblowers in antitrust' (n 30) 293; Wils (n 378) 227.

1228 On the field of anti-cartel enforcement: Harrington Jr. and Chang affirm that "a leniency program can result in more cartels, and this can occur at the same time that a leniency program is generating many applications". See: Harrington and Chang (n 626) 419. Highlighting this risk, Kovacic notes that an agency focused on maximising activity levels runs a risk of making compromises that increase the number of visible outcomes (for example, fines recovered), at the expense of future deterrence". See: Kovacic, 'A case for capping the dosage: leniency and competition authority governance' (n 378) 130. 
rence of serious criminal conduct. ${ }^{1229}$ The proper functioning of the criminal justice system must not constantly depend on the granting of benefits to offenders, which should occur only in a limited and specific manner. ${ }^{1230}$

\section{The judicial control of collaboration agreements}

A pivotal innovation brought by the Brazilian practice of collaboration agreements has been the development of transactions that allowed cooperating defendants to define, at very early stages of an investigation, an exact and all-inclusive punishment that encompassed a wide range of crimes reported in their cooperation report. ${ }^{1231}$ In this type of "package deal", the written agreement precisely outlines the imprisonment penalties, the monetary fines and even the conditions and time of the detention regimes under which the defendant would serve the negotiated punishment. Given the all-embracing reach of agreements, accused can effectively foresee and determine the final results of complex criminal proceedings, often involving a myriad of suspicious conduct related to white-collar crimes, even before any formal charges have been presented.

The Brazilian judiciary has provided an essential support for the consolidation of this type of transaction by understanding that collaboration agreements have a binding effect and that courts must respect, in their decisions, the terms negotiated between cooperating defendants and public prosecutors. ${ }^{1232}$ According to this view, cooperators have - after the fulfillment of their duties - an enforceable right regarding the obtainment of the penalties and benefits established in the written arrangements. ${ }^{1233}$ This position was again grounded in concepts from private contract law: the principles of legal certainty, contractual stability and protection of legitimate expectations compelled courts to honor, in the sentencing phase, the commitments assumed in the agreements concluded by public prosecutors.

1229 As noted by Giancarlo Spagnolo: "The aim of leniency programs is (at least should) not be making the job of prosecutors easier, but rather increasing cartel deterrence". See: Spagnolo (n 30) 293.

1230 Jung (n 442) 40.

1231 See item I.4.a.iii.

1232 See item I.4.c.ii.

1233 Important decisions of the Brazilian Federal Supreme Court affirmed this understanding. See STF, HC 127483 [2015] and STF, PET 7074 [2017]. 
A more thorough analysis reveals how unfounded this facet of the contractualist approach to collaboration agreements is. Retrieving the perspective provided by the 2013 ruling of the German Federal Constitutional Court on the constitutionality of the regulation of negotiated judgments, item V.4.a rejects the position that collaboration agreements engender a compelling binding effect upon judicial sentencing decisions. Item V.4.b denounces the distorted use of collaboration agreements as hedging mechanisms, highlighting the negative externalities that the transactions generate. Item V.4.c concludes by asserting that the existence of rigorous judicial control - in procedural as well as substantive aspects - is a key feature for the development of a sound and legitimate practice of collaboration agreements.

a. Pacta sunt servanda or nemo dat quod non habet? The issue of the binding effect

In its 2013 decision on the constitutionality of the statutory regulation of negotiated judgments, the German Federal Constitutional Court decided that consensual arrangements within criminal investigations could not be carried out in disagreement with basic principles of German criminal procedure. ${ }^{1234}$ According to the court, the principle of individual guilt, the state's commitment to search for truth and the guarantee of due process forbade that legal practitioners disposed unrestrictedly, through consensual arrangements, of the factual inquiry and the definition of criminal punishment. ${ }^{1235}$ Affirming that the imposition of imprisonment penalties can be justified only after the completion of a thorough fact-finding process, the court rejected the possibility of an imprisonment penalty deriving from a simple settlement between procedural participants, rather than from an independent collection of evidence that demonstrates the individual guilt in the commitment of an offense. ${ }^{1236}$

From this perspective, the German Federal Constitutional Court dedicated different parts of its 2013 decision to the issue of the binding effect

1234 For a description of the decision, see item IV.2.e.

1235 See BVerfG, Urt. v. 19.3.2013 - 2 BvR 2628/10 u.a. = BVerfGE 133, 168, para 105.

1236 According to the decision, the imposition of imprisonment penalties without robust evidence of the defendant's guilt is incompatible with the principle of human dignity (ibid., para. 54). 
of consensual solutions within criminal proceedings. The Court expressly recognized that non-binding dialogs between procedural participants can bring benefits to the administration of justice. ${ }^{1237}$ At the same time, the German Federal Constitutional Court asserted that negotiated solutions cannot exempt judicial bodies from their duty to impose a sentence that is compatible with the factual aspects of the case and with their correct legal qualification. ${ }^{1238}$ Due to the state's commitment to ascertain the facts of the case, whenever consensual arrangements do not adequately reflect the factual or legal characteristics of the case, their binding effect on judicial bodies lapses. ${ }^{1239}$ The Court affirmed the importance for defendants to be correctly informed that a consensual solution cannot define the outcome of the criminal proceeding and that judicial bodies may deviate from interparty arrangements. ${ }^{1240}$ Consequently, the Court reasserted that judicial bodies have the duty to expressly inform defendants that consensual arrangements cannot bind judicial decisions under certain circumstances: given the impact of this information on the behavior of the defendant, any negotiated solution that is not preceded by a correct judicial instruction regarding the restricted binding effect of the consensual arrangement must be considered illegal. ${ }^{1241}$

Under the light shed by the 2013 ruling of the German Federal Constitutional Court, the strict application of the principles of contractual stability and protection of legitimate expectations to collaboration agreements, as proposed by the Brazilian Federal Supreme Court, reveals itself as completely inadequate. In the model of negotiation validated by the Brazilian Supreme Court, the parties - the Public Prosecution Office and cooperating defendant - transact over an extensive array of matters, deciding consensually on the wrongful conducts committed by the defendant, on the legal qualification of these conducts, and on the exact punishment applicable.

All these decisions are made at the moment that the parties conclude an agreement, i.e., before the end of the formal investigation and often before the filing of any formal charges. In this type of transaction, the criminal punishment imposed upon the cooperating defendant stems unequivocally from consensual arrangements, becoming detached from any serious

1237 ibid., para. 106.

1238 ibid., para. 73-74.

1239 ibid., para. 69.

1240 ibid., para. 125-126.

1241 ibid., para. 127. 
fact-finding process. The position of the Brazilian Federal Supreme Court affirming the binding effect of collaboration agreements has led to a scenario where cooperating defendants earn, through arrangements negotiated with prosecutors in the beginning of the criminal process, the right to predefined penalties and benefits. Judicial bodies, bound by the inter-party consensual arrangements, become spectators of a play with a previously defined end.

This situation materializes violations of several guarantees of criminal procedure, especially the principle of individual culpability and the state's commitment to search for truth. As noted by the German Federal Constitutional Court in its 2013 ruling, criminal punishment is a state reaction to reproachable individual conduct, and without robust evidence of the individual guilt of the accused, the imposition of criminal penalties violates the concept of human dignity. ${ }^{1242}$ As a condition for the fulfillment of the principle of individual culpability, the state's duty to search for factual truth is the central concern of criminal procedure. ${ }^{243}$ The principle of individual guilt, the state's duty to search for truth and the guarantee of due process prevent procedural participants from transacting freely over the factual investigation, the legal qualification of the defendant's conduct and the definition of criminal sentences. ${ }^{1244}$ They also exclude the possibility for parties to bind, through consensual arrangements, the judicial decision regarding the determination of the facts and its legal qualification. ${ }^{1245}$

It is interesting to note that the purported binding effect of collaboration agreements in relation sentencing decisions of courts, as understood by the Brazilian Federal Supreme Court, indicates a level of deference to consensual arrangements in criminal procedure that appears staggering even by the loose U.S. standards. Throughout the enhanced development of the American system of plea bargaining in the last century, the U.S. Supreme Court supported the widespread use of consensual arrangements in criminal justice based on the concepts of individual autonomy and efficiency. ${ }^{1246}$ This support, however, did not prevent the U.S. Supreme Court from establishing a firm position conferring broad sentencing powers to

1242 ibid., para. 54-55.

1243 ibid., para. 56 and 104.

1244 ibid., para. 105.

1245 ibid., para. 69 and 73-74.

1246 See item IV.4.b.iii. Also: Greco (n 668) 266; Bibas (n 179) 1367. 
courts, who generally enjoy wide discretion over the definition of the appropriate criminal punishment upon convicted individuals. ${ }^{1247}$

These sentencing powers remain largely undisturbed by the inter-party transactions: even when the parties reach an agreement regarding the charges to which the accused will plead guilty, courts normally hold the capacity to define the adequate sentence according to the facts of the case. ${ }^{1248}$ When it comes to cooperating defendants, the vast sentencing powers held by courts unavoidably brings some level of uncertainty to agreements concluded between parties, since the sentencing judge may not recognize the relevance of the provided assistance and confer little or no penalty mitigation for it. ${ }^{1249}$ Therefore, a cooperating defendant cannot know beforehand what precise benefits he will receive at the end of the proceeding, and there is even a chance that his sentence may be aggravated by the elements he voluntarily provided. ${ }^{1250}$

1247 Regarding the development of this jurisprudence, see: Douglas A Berman, 'Foreword: Beyond Blakely and Booker: Pondering Modern Sentencing Process' (2005) 95 The Journal of Criminal Law and Criminology 653, 661-666. For an analysis of the broad sentencing powers of U.S. courts, see: Pizzi ( $\mathrm{n}$ 1191). The author notes the "tremendous sentencing power vested in the trial judge" (69) and that "the judge shifts from neutral and passive referee at trial to the central decision-maker at sentencing" (70).

1248 Stephanos Bibas, 'Judicial Fact-Finding and Sentence Enhancements in a World of Guilty Pleas' (2001) 110 The Yale Law Journal 1097,1155-1156 and 1169. See also the 2011 ruling of the U.S. Supreme Court in Pepper v. United States (570 F. 3d 958), affirming the longstanding principle that "the punishment should fit the offender and not merely the crime" (U.S. Supreme Court, Williams v. New York, 337 U. S. 241), which confers the judicial organ wide discretion to obtain information about the offender, including about the offender's rehabilitation, for an accurate sentencing.

1249 As noted by Ian Weinstein: "Another risk is that the judge will give either little or no reward to the cooperator. The court's decision whether and how much to mitigate the sentence is unreviewable on appeal and may turn on the court's own evaluation of the cooperation, the offense or leniency already granted the defendant in the plea agreement". See: Weinstein (n 3) 592.

1250 As observed by Shana Knizhnik: "In reality, a defendant has no idea what the benefit will be if he cooperates. (...) there is a very real possibility that his cooperation will not be successful (for whatever reason) - in which case, he may end up in a much worse position than had he not said anything at all" . See: Shana Knizhnik, 'Failed Snitches and Sentencing Stitches: Substantial Assistance and the Cooperator's Dilemma' (2015) 90 New York University Law Review 1722, 1745. Noting the same risks faced by cooperating defendants in the U.S. system of criminal justice: Rachel E Barkow, 'Institutional Design and the Policing of Prosecutors: Lessons from Administrative Law' (2009) 61 Stanford Law Review 869. 
In this context, the fierce binding effect of collaboration agreements envisaged by the Brazilian Federal Supreme Court looks even more outlandish. Faced with the broadening of the negotiation room in the practice of collaboration agreements, the Brazilian Supreme Court not only refused to assert the basic principles of the Brazilian criminal justice system - as the German Constitutional Court did in the 2013 ruling on the constitutionality of the $\$ 257 \mathrm{c} \mathrm{StPO}$ - but also displayed a reverence for negotiated criminal solutions that would appear as extreme even in the American legal system.

In the Brazilian legal system, law enforcement authorities responsible for the negotiation of collaboration agreements lack the power to determine verdicts and impose sanctions. Given the inalienable function of judicial bodies in the imposition of a correct verdict and an adequate sentence, collaboration agreements cannot - in regard to the exact definition of imprisonment penalties - entail a "do ut des", but only a "do ut spero" relationship. ${ }^{1251}$ Therefore, any arrangement reached with defendants regarding these issues cannot legally bind the judicial organs' final decisions on these matters. Instead of envisioning a rudimentary application of the concept of 'pacta sunt servanda' in criminal procedure, the Brazilian Federal Supreme Court should have applied another traditional adage of private law: nemo dat quod non habet, which expresses the basic notion that one can not give what one does not own.

b. Negative externalities, private gains and social costs: the distorted use of collaboration agreements as hedging mechanisms

The broadening of the negotiation forum beyond its statutory limits, as seen in the practice of collaboration agreements, is not an exclusive experience of Brazilian criminal procedure. Comparative scholarship indicates that, once the genie of contractual freedom is released within the criminal justice system, it is very difficult to imprison it again. ${ }^{1252}$ In Mirjan Damaska's metaphor, "preventing the spread of inter-party dealings is hard as stifling a yawn once it has begun". ${ }^{1253}$ The German experience with the em-

1251 Malek, 'Die Neue Kronzeugenregelung Und Ihre Auswirkungen Auf Die Praxis Der Strafverteidigung' ( $\mathrm{n}$ 481) 376.

1252 For an analysis of the German experience, see item IV.4.b.

1253 Mirjan Damaska, 'Negotiated Justice in International Criminal Courts' (2015) 2 Journal of International Criminal Justice 1018, 1030. 
ployment of negotiated solutions is a clear example of how legal actors will constantly seek to extend, in day-to-day judicial routines, the boundaries of consensual mechanisms established in criminal legislation. ${ }^{1254}$ In the hands of self-interested practitioners, the legislative regulation, projected to be the ceiling for the possibilities of consensual arrangements, becomes the basis for the development of progressively more audacious transactions. ${ }^{1255}$

Consensual mechanisms allow complex criminal investigations to be replaced by arrangements that lead to a speedy resolution of cases, in a manner that both parties consider appropriate. Especially in circumstances in which the process of truth-finding is burdensome and has uncertain outcomes, as occurs in the so-called "monster-proceedings" of white-collar crimes, all legal actors can take great advantage from a consensual solution. ${ }^{1256}$ The problem with this expansionist movement is that agreements between prosecution and defense in criminal proceedings can create serious negative externalities for the legitimate interests of third parties. ${ }^{1257}$ Consensual mechanisms give rise to the risk that the solution of a criminal proceeding arises from a purely bilateral arrangement and gravely ignores the factual aspects of the case and their correct legal qualification. The es-

1254 For a good description of the widespread disregard of the legislative regulation of negotiated judgments by German legal practitioners, see: Altenhain, Dietmeier and May (n 38). See, also, items IV.2.b and IV.2.e.

1255 A bold innovation in the German practice of negotiated judgments is the development of "package deals" ("Gesamtlösungen"), which resolve simultaneously several proceedings involving one accused. In its 2013 ruling, the German Constitutional Court cites a negotiation that ended in a "family solution": in the case, the defendant accepted a higher imprisonment penalty and, in return, his wife obtained a suspended sentence so that she could take care of their children. See BVerfG, Urt. v. 19.3.2013 - 2 BvR 2628/10 u.a. = BVerfGE 133,168 , para 49. Highlighting the inherent risks in inter-party negotiations in criminal justice, Martin Heger e Robert Pest notes that "as long as a procedure of consensual solution exist, there will occur a bypassing of the regulation of the procedure in the legal practice". See Heger and Pest (n 37) 486.

1256 On the impact of the appearance of "monster-proceedings" on the development of consensual solutions, see Bernd Schünemann, 'Zur Kritik des amerikanischen Strafprozessmodells' (n 25) 555-571.

1257 On this subject, see item IV.4.b. Luis Greco argues that a main problem with the use of consensual solutions in criminal justice relates to the effect of these solutions on the position of other accused. See: Greco, Strafprozesstheorie Und Materielle Rechtskraf (n 668) 276-279. Mirjan Damaska notes that: "It is indeed unlikely that the parties will take into account the full cost that their transaction imposes on others with whom they have no immediate relationship". See: Damaška (n 668) 1028. 
calation of consensual aspects in criminal procedure reduces the state's responsibility in the correct determination of the investigated facts; ${ }^{1258}$ overreliance on mechanisms of consensual solutions within a criminal justice system can lead to a scenario of "systematic abstinence from the search for truth". ${ }^{1259}$

Criminal punishment epitomizes a public recognition that an individual has behaved wrongly and must therefore be sanctioned. ${ }^{1260}$ Since this recognition generates a wide array of effects on society, the completion of a thorough process of fact-finding before the definition of the sentence and verdict, apart from safeguarding the rights of the accused, represents a guarantee for the protection of a multitude of social interests. ${ }^{1261}$ The distortion and tampering of criminal procedure through consensual mechanisms have, thus, impacts that go well beyond the legal sphere of procedural participants. The expansion of the negotiation forum beyond the statutory limits widens the parties' ability to reach an agreement that meets their own interest and externalizes new costs, which will be felt by society or other individuals only in the future.

The risks of the expansion of the negotiation forum beyond the statutory limits are even greater when it comes to leniency policies, such as the rewarded collaboration regulation. Leniency policies give rise to multiple negative externalities that do not affect the contracting parties, leading commonly to scenarios of excessive use. ${ }^{1262}$ Leniency policies offer defendants several opportunities to misrepresent facts, ${ }^{1263}$ obtain disproportionate benefits 1264 and to 'game the system' through sophisticated strategies. ${ }^{1265}$ For law enforcement authorities, leniency policies provide a much faster and less costly manner of obtaining information and evidence, which makes their use highly attractive when compared to other investiga-

1258 Hornle (n 963) 833.

1259 Winfried Hassemer, 'Human Dignity in the Criminal Process: The Example of Truth-Finding' (2011) 44 Israel Law Review 185, 198.

1260 Greco, Strafprozesstheorie Und Materielle Recthskraf (n 668) 1092.

1261 On this point, Thomas Weigend asserts that a purely consensual approach to criminal justice misses "the social function of criminal procedure". According to the author, this objective of criminal procedure can only be achieved "through a serious and intense pursuit of truth and fairness". See: Thomas Weigend, 'Unverzichtbares im Strafverfahrensrecht' (2001) 113 Zeitschrift für die gesamte Strafrechtswissenschaft 271, 304.

1262 Weinstein, 'Regulating the Market for Snitches' (n 3) 565.

1263 See item III.3.a.

1264 See item III.3.b.

1265 See item III.3.d. 
tory tools, even if that comes at the cost of an excessive lowering of penalties or other types of social cost. ${ }^{1266}$ Furthermore, the offender's consent creates an apparent mantle of legitimacy for the imposition of penalties, validating the investigative efforts. 1267

The practice of collaboration agreements in Brazil is a typical example of the undue advantages that parties can obtain through the reckless expansion of the negotiation forum within a leniency policy. For cooperating defendants, this expansion has enabled the achievement of outcomes in criminal procedures that are far better than the ones that could be obtained by complying with the provisions of the Organized Crime Act. The inventive practice of collaboration agreements has allowed offenders to obtain "package deals", leading to much milder penalties than should have been imposed if the rules of the Organized Crime Act were followed. ${ }^{1268}$ It has forged detention regimes that do not exist in Brazilian law, enabling offenders to serve long imprisonment sentences at their own private residences, under very favorable circumstances. ${ }^{1269}$ It has also authorized cooperators to protect part of their wealth from the general rule that determines the seizure of assets obtained through criminal activities. ${ }^{1270}$

The purported binding effect of collaboration agreements has given these extravagant innovations the appearance of enforceable individual rights, much like those derived from private contracts. Due to the application of the principles of contractual stability and protection of legitimate expectations, cooperating defendants and public prosecutors have been able to define in advance the outcome of complex investigations, even before the formal start of a criminal proceeding. As occurred in Germany, the field of white-collar criminality proved a very fertile ground for consensual transactions. ${ }^{1271}$ Given the uncertainties arising from ambiguous legislation, the automatic side effects of criminal prosecution upon legiti-

1266 On this subject, see Kovacic, 'A Case for Capping the Dosage: Leniency and Competition Authority Governance' (n 378); Megan Dixon, Ethan Kate and Janet McDavid, 'Too Much of a Good Thing? Is Heavy Reliance on Leniency Eroding Cartel Enforcement in the United States?' (2014) 12 CPI Antitrust Chronicle 2, 2-6.

1267 Winfried Hassemer, 'Konsens im Strafprozeß', in Regina Michalke and others (eds), Festschrift für Rainer Hamm zum 65. Geburtstag am 24. Februar 2008 (De Gruyter, 2009) 180.

1268 See item I.4.a.iii.

1269 See item I.4.a.i.

1270 See item I.4.a.i.

1271 Since the beginning, the development of the German practice of negotiated judgments has occurred mainly in investigations of white-collar crimes. See: 
mate corporations, and the difficulties in distinguishing criminal behavior from regular conduct, it is hardly surprising that Brazilian legal practitioners tried to overcome the lack of predictability and the excessive costs of "monster proceedings" related to white-collar crimes through negotiated arrangements. ${ }^{1272}$

Based on the combination of wide contractual freedom and a compelling binding effect, procedural participants were able to design sophisticated arrangements that resemble hedging contracts, used in financial markets to minimize volatility and reduce risks in future scenarios of uncertainty. ${ }^{1273}$ In the light of the Brazilian Federal Supreme Court's position, cooperating defendants were able, through collaboration agreements, to 'lock in' a defined amount of criminal punishment for a later moment, in a very similar fashion to hedging contracts, which design purchasing transactions of assets at a fixed price at a future moment. ${ }^{1274}$ Some collaboration agreements even established the cooperator's right to a potential penalty equalization, in case other cooperating defendants from the same business conglomerate managed to obtain a better deal. ${ }^{1275}$

The comparison to the finance industry seems here more suitable than ever: in the brand-new Brazilian market of criminal justice, collaboration agreements not only 'lock in' an exact criminal penalty for a future moment, but also design an insurance policy that triggers the renegotiation of the transaction whenever other buyers purchase the product of the merchants of penalties at a lower price. This type of transaction, apart from contradicting multiple principles of Brazilian criminal procedure, leads to

Schünemann, 'Gutachten, Kongressvortrag, Aufsatz | Absprachen Im Strafverfahren - Grundlagen, Gegenstande Und Grenzen’ (n 38) 17-18; Altenhain, Dietmeier and May (n 38) 20. See also item IV.2.b.

1272 For an analysis of the development and the support of the widespread use of collaboration agreements in the field of corporate criminality, see items II.4 and II.5.

1273 The literature on the use of hedging contracts by corporations is very large. According to Smith and Stulz, the focus of the literature on hedging practices "is generally on risk-averse producers who use forward or futures markets to reduce the variability of their income". See: Clifford W Smith and Rene M Stulz, 'The Determinants of Firms' Hedging Policies' (1985) 20 The Journal of Financial and Quantitative Analysis 391, 391. See also: Peter M DeMarzo and Darrell Duffie, 'Corporate Incentives for Hedging and Hedge Accounting' (1995) 8 The Review of Financial Studies 743; Qiang Li and others, 'Buy Now and Price Later: Supply Contracts with Time-Consistent Mean-Variance Financial Hedging' (2018) 268 European Journal of Operational Research 582.

1274 See Item I.4.a.ii and I.4.c.i

1275 Pet. 6533, Fernando Migliaccio, Clausula 5a , parágrafos 4o e 5o 
a variety of inexplicable situations. While the gains and losses stemming from hedging contracts in financial exchanges are understood as normal occurrences of a market economy, the disparities and inconsistencies generated by this kind of arrangement are irreconcilable with basic values of substantive and procedural criminal law, such as the principle of individual culpability, the transparency requirement and the commitment to a minimum standard of truth-searching. ${ }^{1276}$

c. The overheated cooperation market and the problem of monopoly of selection: a case for broad and in-depth judicial control of collaboration agreements

Much of the Brazilian debate about the limits of the use of the rewarded collaboration regulation is based on a presumed opposition between the public interest in fighting organized crime, particularly corruption schemes and corporate wrongdoing, and the individual rights of the defendants. ${ }^{1277}$ The problem with this position is that it overshadows the most serious challenges that exist in the development of a sound leniency policy. The main risk posed by such policies is not the erosion of individual rights of other accused, which remain (or at least should remain) the same, but rather the many opportunities that these policies provide for the contracting parties (cooperating defendants and law enforcement authorities) to adopt solutions that reflect their own interests and, concurrently, cause diffuse negative externalities.

The introduction of a negotiation forum between prosecution and defense permits procedural participants to develop transactions that inevitably affect other agents who are nor part of the criminal proceed-

1276 As noted by the 2013 ruling of the German Federal Constitutional Court on the constitutionality of the regulation of negotiated judgments. See BVerfG, Urt. v. 19.3.2013 - 2 BvR 2628/10 u.a. = BVerfGE 133, 168, para 105.

1277 For a detailed defense of this position, see: Sarmento (n 35) 450-457. According to the author, the rewarded collaboration regulation "cannot be devised and applied in a manner that violates the fundamental rights of cooperators and other defendants, and cannot be weakened to the point of failing to protect the fundamental rights of the population, which are violated by organized crime and by corruption" (455). 
ing. ${ }^{1278}$ In view of the incentives for parties to design consensual arrangements that create value for them while externalizing costs for other agents, the emergence of an "overheated cooperation market" is not surprising. ${ }^{1279}$ In this regard, the investigatory public-private partnerships between enforcement authorities and offenders resemble production activities that emit air pollution: while they deliver perceptible results and clear advantages for the involved agents, they also produce invisible externalities, which will affect society in a diffuse and protracted manner. ${ }^{1280}$

These risks are exacerbated by the fact that leniency policies greatly increase the relevance of the investigative phase of criminal prosecution, which becomes the defining moment of the course and the outcome of a criminal case. Leniency policies confer a broad field of action on law enforcement authorities in the preliminary stages of the procedure, including the control over which elements of the investigation will be formally registered for future analysis in the trial phase. This "monopoly of selection" ${ }^{1281}$ hinders the judiciary in assessing whether the facts narrated by law enforcement authorities have been discovered in an impartial and correct manner. This scenario is particularly delicate because, in the scenario of partial privatization of state prosecution, the access of public authorities to the shared evidence occurs only after private agents have screened the material and decided what is relevant for the investigation. ${ }^{1282}$

1278 Luis Greco highlights, for instance, the effect of consensual solutions on defendants who are not willing to confess and negotiate a settlement. According to the author, the whole existence of consensual mechanisms in criminal procedure "rests on the stricter punishment of those who insist on asserting their procedural rights". See: Greco, Strafprozesstheorie Und Materielle Rechtskraf (n 668) 278.

1279 Noting the existence of an "overheated cooperation market" in the U.S, see: Weinstein, 'Regulating the Market for Snitches' (n 3) 564.

1280 On the externalities that arise from polluting activities, see: Peter Lewin, 'Pollution externalities: social cost and strict liability' (1982) 2 Cato Journal 205; J V. Henderson, 'Externalities in a Spatial Context. The Case of Air Pollution' (1977) 7 Journal of Public Economics 89.

1281 According to Bernd Schünemann, a current trend in criminal procedure is huge increase of relevance of the pre-trial inquiry phase, in a scenario where the investigative authorities have a "monopoly of selection" over the elements that will be formally registered for exam during the trial phase. See: Schünemann, 'Die Zukunft Des Strafverfahrens - Abschied Vom Rechtsstaat?'(n 695) 948-949.

1282 For a thorough analysis of the risks of the privatization of investigative activities within criminal procedure, see: Stoffer (n 23). 
In this context, in which law enforcement authorities and defendants gain enormous power over the course of criminal investigations, there is no reason to understand that courts should merely perform procedural oversight of the practice of collaboration agreements. Given the specific risks that partnerships between offenders and law enforcement authorities entail, judicial control over collaboration agreements should be just as, or even more intense than, the scrutiny exercised by courts over other aspects of the criminal proceeding.

Regarding this point, it is important to note that Brazilian criminal procedure reserves a central role for judicial bodies. Unlike in U.S. criminal justice, Brazilian courts play an active role throughout different phases of the criminal procedure. In Brazilian criminal procedure, the ascertainment of criminal behavior, the legal qualification of offenses, and the definition of a criminal sentence are exclusive functions of judicial bodies. ${ }^{1283}$ Brazilian courts perform a central function in criminal proceedings, in order to ensure that a conviction is imposed only when the investigation of the facts demonstrates, in an objective and impartial manner, the criminal liability of an individual. ${ }^{1284}$

Leniency policies such as the rewarded collaboration regulation have genuine potential for expanding the state's capacity to discover and solve serious and complex crimes. ${ }^{1285}$ They can also have an important deterrent effect on criminal organizations. ${ }^{1286}$ Nonetheless, these policies entail a series of new risks, which arise from the establishment of principal-agent relationships between law enforcement authorities and offenders in a context of strong informational asymmetry. ${ }^{1287}$ The structure of these partnerships creates various possibilities for defendants to gain undue advantages, through the misrepresentation of facts, ${ }^{1288}$ the obtainment of excessive

1283 See item V.2.c.

1284 For that purpose, Brazilian courts are responsible not only for assessing the defendant's guilt and defining the legal qualification of criminal offenses, but also for guaranteeing an adequate determination of the facts of a criminal case. In order to guarantee proper fact-finding, courts have the power to determine, ex officio, the production of relevant evidence to clarify points of the investigation. Judges may hear witnesses who have not been indicated by the parties and, in urgent situations, may order the production of evidence even before the criminal procedure has begun. See Brazilian Code of Criminal Procedure, art. 156, I and II; art. 209; art. 234.

1285 See item III.2.a.

1286 See item III.2.b.

1287 See item III.3.

1288 See item III.3.a. 
benefits ${ }^{1289}$ and the reverse exploitation of the leniency system. ${ }^{1290}$ These risks are exacerbated by the existence of several incentives for enforcement authorities to transform leniency policies, in the day-to-day routines of the justice system, into instruments of procedural economy. ${ }^{1291}$

In this context, there is a clear need for strict judicial control over the development of leniency policies, in order to avoid the multiple risks that such policies engender. This control must be broad enough to cover the different phases of the practice of collaboration agreements, comprising issues such as the criteria for the selection of the cooperator, the negotiation techniques employed by law enforcement authorities and the benefits granted. It must also be in-depth, in order to ensure compliance with the fundamental principles of Brazilian law, such as proportionality, equality, transparency and the guarantee of individualization of punishment.

The existence of broad and in-depth judicial control is an essential element for the development of a sound practice of collaboration agreements, one that contributes to the discovery of serious crimes, to the distinction between innocent and guilty individuals and to the punishment of the latter through a transparent and legitimate procedure.

\section{Conclusion: the contractualist approach from a comparative perspective}

Confronted with complex and sophisticated transactions concluded between cooperating defendants and the Public Prosecution Office in the investigation of corporate and government crimes, the Brazilian Federal Supreme Court has followed a dubious path.

First, the Court ignored that collaboration agreements are tools that express the state's commitment to search for truth, choosing rather to understand collaboration agreements as simple bilateral transactions that do not affect third parties. Through this understanding, the Court overlooked a fundamental difference between leniency policies, designed to reduce impunity through the enhancement of detection and deterrence of serious

1289 See item III.3.b.

1290 See item III.3.d.

1291 Noting these incentives, see: Jeßberger, Kooperation Und Strafzumessung: Der Kronzeuge Im Deutschen Und Amerikanischen Strafrecht (n 1) 307. On the distortion of incentives caused by leniency policies on the behavior of enforcement authorities, see item IV.3.c. 
crimes, and mechanisms of consensual justice, aimed at abbreviating criminal proceedings and achieving procedural economy.

Secondly, the Federal Supreme Court refrained from asserting basic pillars of Brazilian criminal law, such as the norms of due process, the system of separation of functions, the principle of presumption of innocence and the guarantee of individualization of punishment. Instead, the Court decided to interpret collaboration agreements under the light of principles and concepts of private contract law, such as the protection of legitimate expectations and good faith, the "res inter alios acta" principle, the "venire contra factum proprium" doctrine and the rule of "pacta sunt servanda".

Finally, the Federal Supreme Court neglected the risks arising from the establishment of public-private partnerships within the apparatus of state prosecution and from the partial privatization of official investigations. The Court did not once examine seriously the perils stemming from the principal-agent relationships and from the informational asymmetries that characterize the dynamics of cooperation between offenders and enforcement authorities. The risks of misrepresentation of facts through underand over-cooperation, of an excessive amnesty effect or of a reverse exploitation of the rewarded collaboration regulation were never meaningfully considered.

Given the challenges that exist in the prosecution of white-collar networks, the main field of development of collaboration agreements, the recent enthusiasm of Brazilian legal practitioners for consensual solutions is understandable. As the German experience demonstrates, when faced with complex and burdensome criminal investigations, all actors of the criminal process have strong incentives to search for a settlement that renders a fast and secure outcome. This is particularly true in the context of "monster proceedings" related to white-collar crimes, given the extravagant costs of fact-finding, the uncertainties steaming from vague and ambiguous legislation and the multiple side effects of criminal prosecution upon legitimate corporations. In such circumstances, it is not surprising that procedural participants have tried to employ consensual arrangements as hedging mechanisms to reduce risk, offset costs and achieve a secure result in a scenario of volatility and distress.

What is astonishing in the Brazilian experience with collaboration agreements is the unconditional support granted by the Federal Supreme Court to the bold innovations developed through consensual arrangements. The shortcomings and flaws of the contractualist approach to collaboration agreements are emphasized when contrasted with the position of the German Constitutional Court in the assessment of the constitutionality of ne- 
gotiated solutions in criminal proceedings. Faced with pervasive disregard for the statutory rules by legal practitioners, the German Constitutional Court took a path that, although not immune to criticism, directly confronted several questions that the Brazilian Federal Supreme Court preferred to neglect.

Unlike the German Constitutional Court, the Brazilian Federal Supreme Court did not attempt to tame the inventive practice of consensual arrangements that emerged after the enaction of Organized Crime Act. On the contrary, the Brazilian Court fuelled the growth of consensual innovations, invoking principles of private contract law to block legal actions of third parties against collaboration agreements and to affirm the binding effect of these agreements upon the judiciary.

This tremendous deference to consensual arrangements and the oblivion of traditional pillars of Continental criminal procedure stands in sharp contrast to the German Constitutional Court's affirmation of the principle of individual guilt and the state's duty to search for truth in criminal proceedings. Even when compared to the U.S. experience, the contractualist approach to collaboration agreements appears excessively radical. From a comparative perspective, the approach of the Brazilian Federal Supreme Court regarding collaboration agreements reveals itself as an incomprehensible position that has led to a truly unique experience: the redesign of Brazilian criminal law through sophisticated written agreements. In the blurred context of white-collar criminality, legal practitioners had no problems using the blank check given by the Federal Supreme Court to develop staggering consensual innovations and achieve secure outcomes.

Some aspects of the inventive use of collaboration agreements have become so entrenched in Brazilian case-law and legal scholarship that nowadays it is even difficult to suggest that another model of negotiation is feasible. The rejection of the contractualist approach, and its replacement by the understanding that collaboration agreements represent a type of privatization of official investigations through public-private partnerships, have important consequences for Brazilian legal practice. Chapter VI is dedicated mainly to examining the implications of the rebuff to the contractualist approach. At the end, it also hypothesizes about the reasons for the widespread support found by the inventive practice of collaboration agreements in Brazilian law. 


\section{Chapter VI - Legal consequences and practical implications}

\section{Introduction}

The use of cooperating defendants as an investigative tool is nowadays an ever-increasing reality in multiple jurisdictions. ${ }^{1292}$ In the last decades, several countries have adopted reforms to permit the concession of benefits to offenders who assist public officials in the investigation against co-conspirators. Recently, this movement has shown special vitality in the realm of corporate wrongdoing, where some commentators speak of a 'leniency revolution'. ${ }^{1293}$

In Brazil, the large-scale use of leniency policies has drawn large attention in the massive investigations that since 2014 have inquired into a multitude of practices undertaken by some of the most prominent businessmen and politicians in Brazil. ${ }^{1294}$ Collaboration agreements have generated prompt and visible outcomes, such as the payment of multi-million fines, the establishment of negotiated imprisonment penalties and the disclosure of long and detailed confessions. Although the arrangements negotiated by cooperating defendants and enforcement authorities have no clear legal basis, the Brazilian judiciary has validated the inventive practice of collaboration agreements, associating it with a new form of "consensual criminal justice" and applying principles and concepts from private contract law, such as the doctrines of "res inter alios acta", of "venire contra factum proprium", and of "pacta sunt servanda". ${ }^{1295}$ The results obtained through collaboration agreements in the investigation of corporate and government crimes attracted worldwide attention. ${ }^{1296}$ Since then, collaboration agreements

1292 Regarding the development of this tool in an international perspective see Part III.1.

1293 Spagnolo, 'Leniency and Whistleblowers in Antitrust'(n 30) 259.

1294 About the Car Wash Operation and its impact on Brazil's social and political scene, see Part II.2.

1295 See item I..4.c.

1296 See Transparency International, 'Brazil Carwash task force wins Transparency International anti-corruption award'(2016) <https://www.transparency.org/ne ws/pressrelease/brazils_carwash_task_force_wins_transparency_international_ anti_corruption>, accessed 26 September 2018. 
have been praised as an essential tool for the prosecution of corporate wrongdoing and corruption schemes. ${ }^{1297}$

The widespread support for this development is somewhat understandable. Corporate crimes and corrupt practices, apart from causing individual losses, generate several invidious effects throughout society. The high potential damage is accompanied by the presence of enormous obstacles to effective prosecution, particularly in relation to leaders of legitimate organizations such as corporations and political parties. In this context, it is normal to point to the existence of a particularly severe form of dark figure in the realm of corporate and governmental crimes. ${ }^{1298}$ These obstacles tend to create situations of impunity and generate unexplainable differences of treatment between different social groups, damaging the legitimacy of criminal law. ${ }^{1299}$ Leniency policies appear in this context as a means not only to achieve a more effective system of enforcement, but also to recover its credibility in the prosecution of macro-delinquency.

Rejecting the common approach to the Brazilian rewarded collaboration regulation, Chapter $\mathrm{V}$ elaborated reasons for the development of a more skeptical view of the Brazilian practice of collaboration agreements. Drawing on the concepts from German law analyzed in Chapter IV, it affirmed that the Brazilian practice of collaboration agreements has converted a truth-finding tool into a mechanism for the consensual resolution of criminal cases and denounced the multiple violations of basic principles of Brazilian criminal law and procedure that this conversion engenders. Chapter $\mathrm{V}$ also rejected the use of concepts of private contract law to interpret the rewarded collaboration regulation, especially the res inter alios acta doctrine and the concept of 'pacta sunt servanda', widely used by the Brazilian judiciary to support the practice of collaboration agreements. Suggesting that collaboration agreements should be understood as complex public-private partnerships between enforcement authorities and cooperating defendants, Chapter V pointed out the several risks generated by this intricate process of privatization of investigative and prosecutorial activities.

Furthermore, based on the body of literature regarding the effects of leniency policies examined in Chapter III, Chapter V sustained that the idiosyncrasies of the Brazilian practice of collaboration agreements expands

1297 Kurtenbach and Nolte (n 16) 5.

1298 Jeßberger (n 1) 305.

1299 On this subject, see: Schünemann, 'Vom Unterschichts- Zum Oberschichtsstrafrecht: Ein Paradigmawechsel Im Moralischen Anspruch?' (n 18). 
the possibilities for cooperators to abuse the principal-agent relationships and the informational asymmetry that characterize partnerships between public authorities and offenders. From the perspective that leniency policies design a delicate structure of incentives, Chapter V criticized the complete disregard for statutory boundaries shown by legal practitioners in the negotiation of collaboration agreements. Chapter $\mathrm{V}$ also argued that the early granting of benefits to cooperating defendants intensifies the risks associated with the use of leniency policies, increasing the chances of factual misrepresentation, concession of excessive advantages and reverse exploitation of the leniency system. The rejection of the "contractualist approach" to collaboration agreements has important implications for the Brazilian criminal justice system.

Section VI.2 deals with some consequences of the understanding that collaboration agreements are not simple bilateral transactions, but rather complex and durable public-private partnerships between law enforcement authorities and offenders, drawing some lessons from the Brazilian antitrust leniency program, analyzed in Chapter I, and from the German experience, examined in Chapter IV. Item VI.2.a rejects the Federal Supreme Court's position that third parties do not have the right to question in court the legality of collaboration agreements, asserting that this right represents an individual guarantee as well as a mechanism for protecting the public interest. Item VI.2.b argues that the granting of benefits in collaboration agreements must respect the numerus clausus principle. VI.2.c affirms that the guarantee of equal treatment is crucial for the sound and legitimate development of the rewarded collaboration regulation, requiring the design of transparent and objective criteria. VI.2.d criticizes the regime of early and broad publicity given to collaboration agreements and advocates more careful treatment of cooperating reports and shared evidence. VI.2.e rejects the system of advanced definition and enforcement of negotiated penalties, asserting that this model of transaction creates an unsolvable paradox for the Brazilian justice system. VI.2.f asserts the need to record and regulate the negotiation process for collaboration agreements.

Section VI.3 concludes the thesis by addressing an important question: how could the practice of collaboration agreements - despite all its eccentricities, contradictions and limitations - gain such widespread support in Brazilian society, particularly from the judiciary? Item VI.3.a suggests that the concept of 'governing through crime' offers a productive framework to understand the vigor of the practice of collaboration agreements. Item VI.3.b observes the enhancement of the powers of enforcement authorities brought by the practice of collaboration agreements and examines the con- 
tradictions caused by it. Item VI.3.c critically analyzes the effectiveness discourse that justifies the practice of collaboration agreements and connects it with the concept of "leniency religion". Item VI.3.d asserts the existence of a symbiotic relationship between the practice of collaboration agreements and the recent Brazilian anti-corruption movement, putting forward the dynamics of 'governing through white-collar crime'.

\section{Consequences}

a. The right of third parties to question collaboration agreements in court: protection of individual rights and of the public interest

One conclusion of Chapter V is the rejection of Brazilian higher courts' position that collaboration agreements are pure bilateral transactions, which create rights and obligations solely for the signing agents, without affecting the legal interests of third parties. ${ }^{1300}$

The rewarded collaboration regulation constitutes, in Brazilian law, a tool connected to the state's commitment to search for truth and to the objective of increasing deterrence in scenarios of investigative emergencies. ${ }^{1301}$ The conclusion of a collaboration agreement initiates a partnership between law enforcement authorities and offenders, with the purpose of creating an informational and evidentiary basis - to which the state would otherwise probably not have access - to hold third parties accountable. Thus, these transactions between law enforcement authorities and offenders obviously concern other defendants, whose individual rights will be directly affected by the state's investigation. ${ }^{1302}$

The interpretation of collaboration agreements under the light of the res inter alios acta principle, as proposed by the Federal Supreme Court, is incoherent, since the crux of these agreements is establishing the criminal liability of third parties. On this point, the rewarded collaboration regulation is identical to other investigative measures listed in the Organized Crime Act, such as the interception of communications, infiltration by undercover agents and the lifting of banking confidentiality.

In Brazilian criminal procedure, the use of investigative tools is subject to strict judicial scrutiny and defendants can incidentally question the le-

1300 See item V.3.c

1301 See item V.2.a.

1302 See item V.3.a 
gality of its use, including through a writ of habeas corpus directed to the higher courts. ${ }^{1303}$ Because the Brazilian Federal Constitution provides that evidence obtained through illegal means cannot be admitted by courts, ${ }^{1304}$ and the Brazilian Code of Criminal Procedure determines that all illicit evidence must be removed from trial, ${ }^{1305}$ the right to question the legality of investigative measures is of paramount importance in Brazilian criminal procedure. On multiple occasions, Brazilian higher courts have applied the doctrine of the fruit of the poisonous tree, considering inadmissible evidence which, although faithfully produced, derived from the use of investigative methods that originally violated constitutional or statutory rules. ${ }^{1306}$

Despite representing a tool of investigation and deterrence, the rewarded collaboration regulation has received different treatment from Brazilian higher courts, which have repeatedly decided that defendants mentioned in collaboration agreements have no right to question the legality of these arrangements. ${ }^{1307}$ Invoking the res inter alios acta principle, the Brazilian Federal Supreme Court affirmed that collaboration agreements can only be questioned by the signing agents (the cooperating defendant and the Public Prosecution Office), restricting the other accused's rights to crossexamine in trial the facts narrated by the cooperation report. Based on the same line of reasoning, the Court has decided that the cancellation of a collaboration agreement does not lead to the exclusion of the evidence provided by the cooperating defendant against other accused, understanding that the termination of the agreement only affects the signing parties. ${ }^{1308}$

Once established that collaboration agreements constitute public-private partnerships within the state prosecution apparatus, aimed at establishing the criminal liability of third parties, it becomes clear that this jurisprudential position is unacceptable. Collaboration agreements are not simple bi-

1303 There are various decisions from Brazilian courts that declare, in incidental proceedings filed by defendants, the illegality of wiretappings and dawn raids carried out without strict obedience of legal rules. In the jurisprudence of the Brazilian Federal Supreme Court, see STF, HC 108147 [2012], STF INQ 3732 [2016], STF RCL 24473 [2018].

1304 Brazilian Federal Constitution, art 5 LVI.

1305 Brazilian Code of Criminal Procedure, art 157.

1306 The Brazilian Federal Supreme Court, for instance, has applied this doctrine in many rulings. See e.g. STF, HC 69912 [1993].

1307 See item I.4.c.i.

1308 See STF, INQ 4483 QO [2017]. 
lateral transactions but give rise to complex relationships that necessarily affect multiple parties. The consensual arrangements reached in collaboration agreements are only possible if there is a third party who will be investigated and whose legal interests will be negatively affected by the agreement, as occurs with the use of other investigative tools at the disposal of law enforcement authorities. There is, therefore, no reason to treat judicial control of collaboration agreements in a different manner.

In fact, compared to traditional investigative measures, collaboration agreements and other leniency policies entail greater risks both for the public interest and for the defendant's rights and should, therefore, be under tighter, not looser, judicial control. Leniency policies such as the rewarded collaboration regulation create a scenario of partial privatization of official investigations, where information and evidence are accessed by law enforcement authorities only after a private agent - the cooperating defendant - has identified, selected, and organized the information he or she deems relevant and convenient to be presented. Through collaboration agreements, offenders become active agents of the state prosecution, ${ }^{1309}$ fulfilling the role of a longa manus of law enforcement authorities in the collection of evidence and information against third parties. ${ }^{1310}$

Given the high informational asymmetry between law enforcement authorities and cooperators, this process of privatization creates considerable scope for the misrepresentation of facts, either by means of under-cooperation, when the cooperator partially omits the information, or by means of over-cooperation, when she exaggerates the narrative. ${ }^{1311}$ In the field of corporate and government crimes, where the Brazilian practice of collaboration agreements has mainly been developed, these risks are even greater, since the distinction between serious crimes and regular business practices is an operation of high complexity. ${ }^{1312}$ In a context where legislation uses broad and vague terms to define criminal behavior and offenses are largely carried out through ordinary business and administrative routines, the content of criminal rules becomes blurred and open, ${ }^{1313}$ creating an array of opportunities for wrongful or biased reconstruction of facts. ${ }^{1314}$ Furthermore, given the incentives for offenders and law enforcement authorities

1309 Jeßberger, Kooperation Und Strafzumessung: Der Kronzeuge Im Deutschen Und Amerikanischen Strafrecht (n 1) 26.

1310 First (n 609) 97.

1311 See item III.3.a.

1312 See sections II.3 and II.5

1313 See Hefendehl, (n 390) 64.

1314 See Forrester and Berghe (n 566) 159-178. 
to quickly resolve criminal investigations through consensual arrangements that meet their interests but externalize costs for society and other individuals, broad and in-depth judicial control is necessary for sound implementation of the rewarded collaboration regulation. ${ }^{1315}$

Legal actions presented by third parties represent here both a channel for the protection of individual rights and a mechanism for ensuring that cooperation agreements abide by statutory provisions, preserving the system of incentives designed by the legislator.

\section{b. The array of leniency benefits: a case for numerus clausus}

Another consequence of the thesis discussed in the previous chapter concerns the benefits that can be offered to offenders who enter into collaboration agreements. The main incentives set forth by the Organized Crime Act are the granting of full immunity, through judicial pardon or dropping of charges by the Public Prosecution Office, the reduction of criminal sanctions by up to two thirds or the replacement of imprisonment penalties by penalties of rights restrictions. ${ }^{1316}$

However, based on the understanding that the provisions of the Organized Crime Act do not limit the parties' capacity to transact, the Brazilian practice of collaboration agreements has been marked by the establishment of new forms of benefits that lack statutory support, such as the design of "differentiated" detention regimes, the protection of assets acquired through criminal activities and the regulation of criminal prosecution against family members of the cooperator. ${ }^{1317}$ According to this position, the boundaries of the parties' contractual freedom in the realm of collaboration agreements are set by general principles of law, and not defined strictly by the text of the Organized Crime Act. ${ }^{1318}$ As a consequence, cooperating defendants and law enforcement authorities are largely free to

1315 See V.4.d. Defending a broad judicial control, see Fred Didier Jr. and Daniela Bomfim, 'Colaboração Premiada (Lei n. 12850/2013): natureza jurídica e controle da validade por demanda autônoma - um diálogo com o Direito Processual Civil' (2016) 7 Civil Procedure Review 135, 173-179

1316 Brazilian Organized Crime Act 2013, art 4. See item I.3.b.i.

1317 See item I.4.a.i.

1318 Defending this position, see ENCCLA (185) 7; and Mendonça (n 36). The Brazilian Federal Supreme Court has endorsed this position. See e.g. STF, INQ 4405 AgR [2018]; and STF, HC 127483 [2015]. 
devise new forms of benefits, as long as some generic guidelines are respected.

This understanding is unsound and leads to perverse outcomes for the Brazilian criminal justice system. Collaboration agreements, like any other leniency policy, always have a "dark side". ${ }^{1319}$ Granting benefits enhances the profits obtained from criminal behavior and creates an "amnesty effect", ${ }^{1320}$ which may end up stimulating the commitment of crimes. ${ }^{1321}$ The concession of excessive benefits creates an easy escape for cooperating defendants and may lead to unjustified scenarios of impunity. ${ }^{1322}$ Therefore, the establishment of clear boundaries, which limit the scope for reducing the penalty level, ${ }^{1323}$ is an essential element of leniency policies. ${ }^{1324}$

The statutory provisions of the Brazilian rewarded collaboration regulation express, therefore, a necessary and extremely delicate balance between the gains and costs of the use of cooperating defendants. The devising, through collaboration agreements, of new forms of benefits not provided for by law, disrupts this balance and tends to create opportunities that are excessively favorable to cooperating defendants. The short Brazilian experience with collaboration agreements shows how the development of a flexible system of negotiation beyond its statutory limits can lead to consensual innovations that completely change, in an uncontrolled manner, the system of incentives set by the legislation.

A clear example is the design, through collaboration arrangements, of new forms of detention regime, which are completely different from the ones established in Brazilian criminal legislation. ${ }^{1325}$ The so-called "differentiated closed regime", "differentiated semi-open regime" and "differentiated open regime" create the possibility for offenders to serve long imprisonment sentences in their private residence, without spending a single day in a prison or official institution. The tailor-made approach has led to the design of a new "differentiated" detention regime for every single collaboration agreement, creating a personal set of rights and restrictions for each cooperating defendant.

While favoring the conclusion of collaboration agreements with defendants, the design of these new detention regimes increases the amnesty ef-

1319 Acconcia and others (n 29) 1118. See item III.3.b.

1320 Harrington Jr. (n 29) 217. Ver item III.3.b.

1321 Motta and Polo (n 29) 349.

1322 Marvão and Spagnolo (n 32) 91.

1323 Wils (n 520) 348.

1324 Spagnolo (n 30) 293.

1325 See item I.4.a.i. 
fect of the rewarded collaboration regulation to unithinkable levels, creating favorable situations for cooperators that are totally disconnected from the provisions of the Organized Crime Act and Brazilian substantive criminal law. The same occurs with other consensual innovations brought about by the practice of collaboration agreements: the granting of protection to personal assets of cooperating defendants, even when acquired from the proceeds of criminal activities. ${ }^{1326}$ Although the Brazilian criminal legislation prescribes that assets related to or acquired through criminal practices must be seized and the Organized Crime Act does not provide for any exception to this rule, collaboration agreements have permitted defendants to retain high valued, illegally acquired assets, a consensual innovation that has been expressly endorsed by the Federal Supreme Court. ${ }^{1327}$

The development of a flexible model of agreements clearly simplifies the activities of law enforcement authorities. The appeal of this model is understandable: through the design of new benefits, law enforcement authorities can constantly create new incentives for defendants to cooperate against former co-conspirators, boosting the use of the rewarded collaboration regulation. Leniency policies are highly attractive for enforcement agencies when compared to other investigatory measures, since they outsource to private agents - the offenders - the process of collecting, screening and organizing information and evidence, enormously reducing the uncertainties and difficulties that exist in the reconstruction of past events, especially in the complex arena of corporate and political life. ${ }^{1328}$ The reduction of costs brought by this outsourcing process stimulates the use of leniency policies in comparison to other investigative tools, and the achievement of fast results encourages the employment of elastic and generous negotiation standards. ${ }^{1329}$

However, any new benefit created through the practice of collaboration agreements represents an increase in the amnesty effect of the rewarded collaboration regulation and, consequently, a weakening of the deterrent effect of Brazilian criminal law. Although the consensually designed advantages favor both parties of the consensual arrangement, with defendants receiving extraordinary advantages and public authorities achieving

1326 See STF, Collaboration Agreement of A.Y. [2014], clause 7 para 3.

1327 As noted in item I.4.a.i. See STF, HC 127483 [2015].

1328 See item III.3.c

1329 Marvão and Spagnolo (n 32) 92. 
fast outcomes, they impair the public interest in maintaining an adequate level of penalties.

The consensual development of new benefits in collaboration agreements has, therefore, profound repercussions throughout the system of justice. Such innovations not only allow for arrangements that are far more advantageous than is provided for by statutory provisions, but also create incentives for potential cooperators to seek even greater benefits in future transactions. In a negotiation forum with no strict borders, every benefit is imaginable and contractual creativity will certainly flourish. It is, therefore, little surprise that the Brazilian practice has devised bold innovations, such as a "success fee" for the cooperating defendant. ${ }^{1330}$

The granting of benefits not foreseen in the Organized Crime Act undermines the public interest in maximizing deterrence and, at the same time, makes the justice system extremely unsystematic and random. A successful leniency policy depends both on the design of incentives for offenders to cooperate as well as on the setting of fixed boundaries. Limiting the possibilities of negotiation to the boundaries of the Organized Crime Act is essential for the rewarded collaboration regulation to achieve its goal: to create incentives for potential cooperators in an organized and predictable way, while preserving an adequate penalty level for those responsible for serious crimes. The statutory array of benefits appears here not as a mere catalog of options, but rather as an exhaustive and closed list of potential transactions. ${ }^{1331}$ In other words, it is a clear case for the application of the numerus clausus principle, as occurs in other fields of law, where consensual arrangements must observe a fixed number of standardized forms. ${ }^{1332}$

1330 See STF, Collaboration Agreement of A.Y. [2014], para 4.

1331 Along the same lines: JJ Gomes Canutilho and Nuno Brandão, 'Colaboração premiada e auxílio judiciário em matéria penal: a ordem pública como obstáculo à cooperação com a operação Lava Jato' (2016) 146 Revista de Legislação e Jurisprudência 29; Bottino (n 36).

1332 Regarding this subject, see: Thomas W Merrill and Henry E Smith, 'Optimal standardization in the law of property: the numerus clausus principle' (2000) 110 Yale Law Journal 1; Christina Mulligan, 'A Numerus Clausus Principle for Intellectual Property' (2013) 80 Tennessee Law Review 235; Avihay Dorfman, 'Property and Collective Undertaking: The Principle of Numerus Clausus' (2011) 61 University of Toronto Law Journal 467. 
c. The guarantee of equal treatment and the bazaar of punishment

Collaboration agreements, like other leniency policies, are based on consensual exchanges between private agents and public officials. The negotiation of these agreements is underpinned by strategic and pragmatic considerations of law enforcement authorities, with the purpose of achieving more effective results in the prosecution of criminal organizations. Such strategies involve numerous decisions of a discretionary nature, concerning, among other issues, which offenders may have access to the leniency policy, what kind of evidence they must produce and what benefits they may obtain.

In this context, one of the risks arising is that the subjective criteria and the idiosyncratic aspects inherent to a process of negotiation jeopardize the guarantees of equal treatment and transparency by the criminal justice system. Collaboration agreements create durable partnerships between law enforcement authorities and defendants directed at establishing the criminal liability of third parties. The outcomes of such partnerships are uncertain and will appear only in a distant future, after the completion of a complex process of fact-finding. Given the various obstacles that will be faced together, an intrinsic feature of collaboration agreements is the establishment of a bond of mutual confidence between public officials and defendants. As in other joint ventures, a relation of trust is essential for a successful undertaking. Reconciling the personal nature of these relationships with the duties of impartiality and objectivity of public authorities is a difficult task that can raise serious problems. ${ }^{1333}$

In the absence of clear rules regarding the type of assistance that defendants must provide and the corresponding benefits that they can obtain through leniency policies, reductions in penalties may vary widely between similar cases, without any legitimate reason. The lack of precise guidelines creates opportunities for arbitrary decisions within the justice system, with leniency benefits being based not on the objective value of the cooperation, but on the personal preferences and biases of law enforcement officials. ${ }^{1334} \mathrm{Wide}$ discretionary powers in the selection of cooperators and in the definition of the benefits compromise basic principles of

1333 Moss (n 1103) 308 e 309.

1334 Ian Weinstein cites evidence suggesting that, in the American experience, the granting of benefits correlates with characteristics such as race and gender, and not with the value of the provided assistance. Weinstein, 'Regulating the Market for Snitches' (n 3) 611. 
criminal law and, at the same time, jeopardize the obtainment of secure results in criminal investigations. ${ }^{1335}$

The guarantee of equal treatment represents a central pillar of the Brazilian criminal justice system and there is no reason to understand that the development of the rewarded collaboration regulation should occur in complete disregard of this constitutional requirement. Advantageous treatment conferred upon cooperating defendants is only legitimate if founded on objective circumstances and transparent criteria that permit the differentiation between the cooperator's situation from the condition of other accused. ${ }^{1336}$ The codification of leniency policies, with the purpose of establishing the rules for the cooperation system in a public, universal and transparent manner, is a crucial element for achieving the aspired objectives. ${ }^{1337}$ At this point, the comparison between the antitrust leniency program, provided for in the Brazilian Competition Act, and the rewarded collaboration regulation, established by the Organized Crime Act, shows significant differences.

The Brazilian antitrust leniency program grants full immunity, both in the administrative and the criminal spheres, to the first offender who informs on the cartel, prohibiting the concession of benefits to other accused. By adopting a "winner-takes-it-all" model, the program creates a race between the offenders to be the first to blow the whistle on the illegal conduct and, therefore, be the only one to obtain leniency benefits. In cases in which the leniency application is submitted before the Brazilian competition authority becomes aware of the infringement, there is only one benefit to be obtained by the cooperator: full immunity from the penalties applicable to cartel activities, both in the administrative and criminal spheres. ${ }^{1338}$ In other situations, when the competition authority was already aware of the infringement, the cooperator will be entitled to criminal immunity, but in the administrative sphere the benefit will be limited to a penalty reduction of one to two thirds. ${ }^{1339}$

The rewarded collaboration regulation, on the other hand, adopts a system of "quid-pro-quo" transactions, in which the benefits granted to offenders are defined in each individual case based on a range of abstract criteria, such as the personality of the cooperating offender, the circum-

1335 Colombo (n 383).

1336 Wils (n 378) 233.

1337 Spagnolo (n 30) 263.

1338 Brazilian Competition Act 2011, art $86 \$ 4$ para I.

1339 Brazilian Competition Act 2011, art 86 \4 II. 
stances and social repercussion of the criminal act and the effectiveness of the cooperation. There is no clear rule defining in advance the benefit to which the cooperator will be entitled. Nor is there any limit to the number of actors who can benefit from the leniency policy in the same investigation. The level of uncertainty and indetermination has been hugely increased by the Brazilian practice of collaboration agreements, with legal practitioners using the system of "quid-pro-quo" negotiations to develop a flexible system of transactions, creating several benefits not provided for by law and designing a customized agreement for every cooperator. This tailor-made approach has made the system of cooperation even more obscure and unpredictable, with each agreement containing unique provisions that render an objective comparison almost impossible.

Although both systems of negotiations are subject to the risks intrinsic to leniency policies, there is a clear difference in the model of exchanges under the Competition Act and the Organized Crime Act. In the antitrust leniency program, the offender seeks to meet objective criteria to achieve a predetermined benefit. The negotiation forum is narrow, since the benefits and the conditions for its concession are directly provided for by the statutory text. This is clearly a very different model of negotiation when compared to the practice of collaboration agreements, in which defendants cannot foresee the requirements of a successful cooperation or the applicable benefits, and public officials are totally free to decide when, with whom and on what they will transact. The disparity between the two systems can be understood as "a difference between a store that offers fixed discounts and an oriental bazaar where deft haggling constitutes a virtue". ${ }^{1340}$

Law enforcement authorities, however, are not merchants of penalties and benefits, who can arbitrarily dispose of criminal punishment. The development of leniency policies must respect the guarantee of equal treatment, through the design of transparent criteria for the negotiation and granting of benefits and through a solid, coherent and specific explanation for the different situations created for cooperating defendants. In this regard, an interesting decision of the European Court of First Instance altered the benefits granted by the European Commission to a cooperating defendant in a cartel investigation, asserting that the appraisal of the relevance of the cooperation was based on "random factors", in a violation of

1340 Damaška (n 668) 1030. 
the principle of equal treatment. ${ }^{1341}$ Preferential treatment based on random or fortuitous factors represents a breach of this guarantee and should be repaired through strict judicial control.

d. Disclosure and confidentiality: cooperators as the monopolists of truth

Confidentiality represents a central issue in the rewarded collaboration regulation. Several provisions of the Organized Crime Act regulate the issue, establishing duties of secrecy and setting access restrictions to the material provided by the cooperator. A specific rule provides that the confidentiality of a collaboration agreement lasts until the formal beginning of the criminal process, with the judicial acceptance of the charges presented by the Public Prosecution Office. ${ }^{1342}$

Despite these statutory provisions, the Brazilian practice of rewarded collaboration regulation has received enormous media coverage, with the content of collaboration agreements being widely publicized from the outset of the investigations. ${ }^{1343}$ On several occasions, elements obtained through agreements were disclosed to the public at very early stages of the official inquiry, even before the opening of a formal proceeding. Over recent years, cooperating reports and wide collections of evidence provided by cooperating defendants - containing detailed confessions, tapped phone calls and recorded meetings, internal corporate documents and hundreds of hours of videotaped depositions - became a major and a common source for media coverage. ${ }^{1344}$ Given that a large portion of the reported conducts involved the Brazilian political and economic elites, including world-renowned executives and high-ranking politicians, collaboration agreements generated huge public interest and gained massive exposure in the press.

As in other cases of detachment between the statutory provisions of the rewarded collaboration regulation and the "law in action", the Brazilian

1341 See Joined Cases T-45/98 and T-47/98 Krupp Thyssen Stainless $v$ Commission [2001] ECR II - 3757.

1342 Brazilian Organized Crime Act 2013, art $7 \$ 3$.

1343 Marcus André Melo, examining the impacts of Operation Car Wash, notes: "Media coverage of the scandal hit citizens with an informational tsunami. (...) In Brazil, the detailed testimonies of plea-bargain witnesses received huge publicity." See Melo (n 14) 60.

1344 Mello and Spektor, 'Brazil: the costs of multiparty presidentialism' (n 321) 113-114. 
judiciary opted to support the consensual innovations developed by legal practitioners. Using the consolidated understanding that collaboration agreements are bilateral transactions which do not affect third parties, it was easy for courts to interpret the regime of wide publicity as a legitimate decision by the two contracting parties. The position that confidentiality rules exist for the benefit of cooperators and law enforcement authorities, and not to protect defendants accused through the collaboration agreements, allowed the exposure of the provided evidence at very early stages of the investigation and blocked legal challenges raised by other defendants. ${ }^{1345}$

The wide and early publicity given to collaboration agreements was also justified on the grounds that the seriousness of the investigated conduct precluded the confidential processing of the collected evidence and information. Based on the understanding that the investigation of public corruption should be as transparent as possible, law enforcement authorities and courts adopted an explicit attitude of broad disclosure. On multiple occasions, the Federal Supreme Court determined, at the request of the Public Prosecution Office, a premature end to the secrecy of collaboration agreements, stating that basic constitutional principles required Brazilian society to become aware of the content of the investigations. ${ }^{1346}$

This position of wide and early publicity of collaboration agreements ignores that the purpose of the confidentiality regime established in the Criminal Organization Act is not only to guarantee the investigation's success and the cooperator's privacy, but also to protect third parties under investigation, who will be affected by the partnership between law enforcement authorities and cooperating defendants. Given that collaboration agreements entail a partial privatization of the official investigation, with cooperating defendants engaging actively in functions such as the collection and screening of evidence, the premature disclosure of agreements generates serious risks.

Unlike other investigative tools, the state's access to evidence and information through collaboration agreements does not occur directly, being mediated by private agents - the cooperators - who took part in the criminal behavior. Enforcement authorities will only access the shared material after cooperating defendants have selected and organized it. The rewarded collaboration regulation, like other leniency policies, gives offenders a cen-

1345 For a similar view, see the following decision: STJ, APn 843 AgRg [2016].

1346 See e.g. STF, PET 6149 [2016]; STF, PET 6122 [2016]; STF, PET 6150 [2016]; STF, PET 6121 [2016]; PET 5254 [2015]. 
tral role in the process of reconstruction of past conduct. In view of the large informational asymmetry between authorities and offenders, this empowered position can be easily misused, leading to biased selection of evidence and an erroneous account of events. ${ }^{1347}$

This is particularly true in the field of corporate and governmental crimes, where criminal strategies are implemented through ordinary bureaucratic routines, criminal legislation employs vague and sweeping concepts and the distinction between criminal behavior and regular conduct is often a legal conundrum. The prosecution of this type of crime requires the gathering of evidence related to a large number of ostensibly legal acts, carried out by many agents over a long period of time, such as meetings, payment orders and commercial policies. ${ }^{1348}$ Selecting and organizing this complex factual framework to differentiate legal conducts from serious wrongdoings is obviously an extremely delicate activity, with small distortions or omissions causing major impacts on the establishment of criminal liability.

Leniency policies allow cooperators to play a key role in connecting the related facts to the investigated crimes and, more important, to produce a coherent narrative that explains and gives a criminal meaning to an enormous spectrum of acts. In the prosecution of white-collar crimes, collaboration agreements present, often for the first time, a narrative that relates various scattered facts and reports them in an organized manner, indicating their alleged illegal nature. Given the informational asymmetry between public authorities and cooperators, the latter will always have, at early stages of the investigation, control over the selection of the shared material and the development of the investigatory narrative.

In this context, cooperators are the first to determine which conducts will be presented and how they should be portrayed, reconstructing complex events in the light of their own interests. The early disclosure of collaboration agreements permits the wide dissemination of this self-interested version before any independent check on its veracity. Although the establishment of any criminal liability is still very distant, the release of a cooperation report, which comes with a layer of apparent credibility, is enough to bolster or cement a narrative in the public debate. Criminal investigations generate an immediate negative stigma and their side effects can represent a social death in some arenas. While producing enormous damages to the other accused, the early disclosure of agreements allows co-

1347 See item III.3.a.

1348 In this regard, see chapter II. See also Bannenberg (n 17) 108. 
operators to be the first to propagate their view of the facts through an organized report, an issue of paramount importance in legitimate enterprises. In a scenario of blurred lines and factual uncertainty, the cooperator becomes the main storyteller, monopolizing the investigative narrative during a crucial period.

Here again the Brazilian experience with the antitrust leniency program can provide some useful guidance. The regulation of the competition authority establishes a structured regime of confidentiality, which designs a progressive disclosure of the leniency content according to the phases of the proceeding, with a large portion of the shared material remaining confidential until the final judgment of the case. ${ }^{1349}$ Furthermore, the publicity of the cooperation occurs mainly through official documents that analyze and classify the provided evidence and information, and not through the cooperation report drafted by the beneficiary of the leniency. This careful treatment of the disclosure of leniency evidence is similar to the position adopted by other competition authorities, which devise restrictive regulations on the public's access to the shared material. ${ }^{1350}$

The confidentiality of leniency policies such as the rewarded collaboration regulation is a matter of high complexity, affecting multiple competing interests. ${ }^{1351}$ Besides guaranteeing the investigation's success and protecting the cooperator, confidentiality rules also safeguard the rights of the other accused, who will carry the burden of the indictment. Furthermore, the victims of the committed crimes have a right to compensation that often depends on access to leniency documents. Lastly, there is a public interest in the accurate and timely disclosure of conduct investigated in criminal proceedings. Under these circumstances, the posture of general and early publicity, as adopted in the Brazilian practice of collaboration agreements, represents an easy - and mistaken - answer to a complicated question.

1349 See Resolution 21/2018 (11 September 2018) <http://www.cade.gov.br/assunto s/normas-e-legislacao/resolucao/resolucao-no-21-de-12-de-setembro-de-2018.pdf /view> accessed 13 March 2019.

1350 See Antônio Caruso, 'Leniency programmes and protection of confidentiality: the experience of the European Commission' (2010) 1 Journal of European Competition Law \& Practice 453.

1351 As recognized by the European Court of Justice in its famous decision on the Pfleiderer case. See Case C-360/09 Pfleiderer AG v Bundeskartellamt [2011] ECR I-05161. For further analysis, see Gaëtane Goddin, 'The Pfleiderer Judgment on Transparency: The National Sequel of the Access to Document Saga' (2012) 3 Journal of European Competition Law \& Practice 40. 
e. Advanced enforcement of penalties and the paradox of investigating what has already been determined

The rewarded collaboration regulation introduced a new negotiation forum between law enforcement authorities and defendants to the Brazilian criminal justice system. The practice of collaboration agreements expanded this negotiation forum beyond its statutory boundaries, creating multiple important innovations through consensual arrangements concluded by procedural participants. ${ }^{1352}$ A striking novelty brought by the Brazilian practice of rewarded collaboration was the introduction of the possibility for cooperating defendants to serve negotiated imprisonment penalties in advance, before the judicial verdict and sentence. ${ }^{1353}$

This model of transaction transforms collaboration agreements into mechanisms for the consensual resolution of criminal cases, insofar as it determines beforehand the outcome of an official investigation, with the definition and the enforcement of imprisonment penalties being carried out at the initial phases of a criminal proceeding. Through these agreements, the imposition of punishment to a cooperating defendant arises from a consensual solution negotiated with law enforcement authorities at the beginning of the investigation, and not by a decision rendered by a court after the conclusion of the regular legal proceeding.

This expansion of the negotiation forum is unacceptable, since it simultaneously contradicts constitutional principles of Brazilian criminal procedure and the rationale of leniency policies.

The definition and serving of imprisonment penalties based solely on consensual arrangements leads to a clear violation of the due process guarantee, since it allows the punishment of cooperating defendants to be fixed and served before the investigatory phase has been concluded and their guilt has been determined. ${ }^{1354}$ This also leads to a breach of the system of separation of functions established in Brazilian criminal law, which grants solely to judicial bodies the power - at the end of the criminal proceeding - to render a verdict and define the sentence. ${ }^{1355}$

Collaboration agreements are fact-finding tools to be used within regular proceedings, rather than an alternative path to define consensually the outcome of criminal cases. The introduction of the rewarded collaboration

1352 See item I.4.a

1353 See item I.4.a.iv.

1354 See item V.3.b.

1355 See item V.3.c. 
regulation by the Organized Crime Act does not represent the adoption of a new consensual justice system, nor does it replace the traditional structure of law enforcement in the Brazilian legal system. ${ }^{1356}$ Thus, the conclusion of a collaboration agreement between law enforcement authorities and a cooperating defendant cannot be treated as a functional equivalent to a judicial verdict and may not produce the same legal effects.

Clauses that allow penalties to be served in advance, sometimes even before the formal opening of a criminal proceeding, are therefore completely unacceptable. These provisions, in addition to contradicting the most basic constitutional guarantees, create a paradoxical situation, since the criminal proceeding against the cooperating defendant must, according to Brazilian law, continue. Although the penalties defined in the agreement are already being served, the investigation of the offenses that would result in such penalties will continue and, at the end of the process, the cooperator may be acquitted or sentenced to a lower penalty than the one established in the agreement.

Legal practitioners sought to solve this inexplicable situation through another consensual innovation. Through specific clauses of collaboration agreements, cooperators exempted the Brazilian state from any liability if, at the end of the criminal procedure, they were not convicted or sentenced to penalties lower than the ones established and already carried out based on the agreements. ${ }^{1357}$ The risk of the undue expansion of the negotiation forum designed by the rewarded collaboration regulation appears here in its entirety. Introduced in the Brazilian law to enhance the collection of evidence in the prosecution of criminal organizations, collaboration agreements have become a mechanism for the consensual imposition of criminal punishment before the official investigation has been completed or even opened. Rather than facilitating the distinction between guilty and innocent, which is one of the essential duties of any system of justice, ${ }^{1358}$ the practice of collaboration agreements in Brazil has made this distinction

1356 See item V.3.b.

1357 See STF, Collaboration Agreeement of J.S.O.M [2016], clause 5 para 1 item "e".

1358 Regarding the importance of the principle of individual culpability, see Heger, 'Die Internationalen Menschenrechte und das Strafrecht Einige Anmerkungen zur Rechtslage in Deutschland und Brasilien' (n 1260) 1092-1093. As Bernd Schunemann emphatically asserts: "Criminal law separates citizens from delinquent, free men from the ones who will be kept in a cage like creatures" . See: Schünemann, 'Die Zukunft Des Strafverfahrens - Abschied Vom Rechtsstaat?' (n 695) 945. 
even more obscure, engendering a truly unique situation: the possibility that a defendant who has served negotiated imprisonment penalties is acquitted at the end of the proceeding, having already signed a waiver exempting the Brazilian state from any liability.

In addition to violating basic constitutional guarantees, the use of collaboration agreements to define and impose imprisonment penalties upon cooperators contradicts the rationale of leniency policies. Collaboration agreements form a partnership between law enforcement authorities and offenders to investigate wrongdoings carried out by third parties. From the perspective of the public interest, the benefits granted to a cooperator are only justified if the partnership leads to an actual decrease of investigative emergencies and enhances the state's capacity to prosecute and punish other individuals. As these positive effects can only be assessed at the end of the proceedings, the granting of benefits in advance is counterproductive. When a collaboration agreement is concluded, the informational asymmetry between law enforcement authorities and the cooperator is at its peak, creating several opportunities for misrepresentation ${ }^{1359}$ and exploitation $^{1360}$ leading to indefensible situations, as the Brazilian experience itself indicates.

In several cases, the progress of investigations showed that the cooperation provided by defendants who already had received benefits was useless or flawed, forcing the revision of agreements. In one situation, the Federal Public Prosecution Office, after the end of the investigation phase, noted that the cooperating defendant had "received his reward immediately, based on the promise of effective cooperation, which didn't occur" and asked for the rescission of the agreement and imposition of new penalties on the cooperator. ${ }^{1361}$ In another, the Federal Police, after examining the collection of evidence submitted by a defendant, concluded that the cooperation was ineffective and incapable of proving the commitment of any crime by other individuals. ${ }^{1362}$ In a third situation, cooperators who signed an agreement in which the Federal Public Prosecution Office had agreed to not press any charges were put under pre-trial detention and had their

1359 See item III.3.a.

1360 See item III.3.d.

1361 See the motion presented by the Federal Public Prosecution Office, in 1/09/2016, in the following proceeding: JFDF, AP 42543-76.2016.4.01.3400 [2016].

1362 See the analysis report provided by the Brazilian Federal Police: STF, INQ 4367 RAPJ 76 DICOR/PF [2017]. 
benefits suspended, after the emergence of evidence pointing to several omissions and distortions in the cooperation report. ${ }^{1363}$

The Brazilian antitrust leniency program shows that the development of a successful leniency policy does not depend on the violation of due process through the advanced enforcement of negotiated penalties. In the antitrust leniency program, which also confers immunity from criminal prosecution, the granting of benefits to cooperators is only implemented after the normal completion of the fact-finding process, when the Administrative Court of the Brazilian competition authority will decide on the guilt or innocence of all defendants, assessing simultaneously the correctness and veracity of the report presented by the leniency beneficiary. In this system, the conclusion of a leniency agreement is not equivalent to a conviction, nor is it possible to speak of early enforcement of the negotiated penalties.

f. Preparatory acts, the control of the negotiation process and the duty to register

Another important implication of the conclusions expounded in Chapter $\mathrm{V}$ concerns control over the course of the negotiation that precedes the conclusion of a collaboration agreement. Due to an express provision of the Organized Crime Act, judicial bodies are prohibited from engaging in the negotiation of collaboration agreements, which leaves the contracting parties basically free of any oversight at the negotiation table ${ }^{1364}$. The process of interaction and communication between law enforcement authorities and offenders before the signing of a written agreement is informal in nature and is conducted under a heavy veil of secrecy. In order to achieve a common understanding, public officials and defendants meet several times and debate the terms of the arrangement and the final version of the cooperating reports over several months.

In this context, when the conclusion of a collaboration agreement is revealed, various important questions arise. When did the first contact between the parties occur? Who originally proposed the negotiation of the agreement: the cooperating defendant or the enforcement authorities? How was the negotiation developed and which were the original versions of the cooperation reports? Did other negotiations with potential coopera-

1363 See STF, AC 4352 [2017].

1364 Organized Crimes Act, art. 4, \$60. 
tors occur simultaneously? The Brazilian judiciary has devoted little attention to these issues and generally rejected scrutiny of the preparatory acts of collaboration agreements, denying other defendants permission to access and question the details of the negotiation process. ${ }^{1365}$

From the perspective provided by Chapter V, this position emerges as clearly unacceptable. Once it is defined that collaboration agreements are mechanisms that entail a partial privatization within the system of criminal justice, outsourcing investigative and prosecutorial activities to private agents (the offenders), it becomes clear that the preparatory acts to the conclusion of an agreement constitute a central point of the criminal investigation and cannot, therefore, be exempt from a thorough inquiry.

Leniency policies, such as the rewarded collaboration regulation, hugely enhance the importance of the pre-trial investigative phase, which becomes the fulcrum of the development of criminal prosecutions. It is in the negotiation process between cooperators and enforcement authorities that defining questions of an investigation will receive, at least initially, an answer. What crimes were committed? Who were the co-conspirators? What evidence substantiates the accusations? All these fundamental issues will be settled through close communication between public officials and defendants behind closed doors, without interference from a supervisor, mediator or any third party.

In this light, the negotiation process of a collaboration agreement appears as the polar opposite of the ideal of a public, transparent and fully documented trial, coordinated and monitored by an independent judicial body. The confidential bargaining process defines not only the legal situation of the cooperating defendant, but also the direction of the investigation against the other accused. The cooperator's version will have to be proven in trial afterwards, but once the investigative train has left the station it is obvious how difficult it is to change its route or slow its pace.

A closer look reveals two driving forces in the negotiation of consensual arrangements within criminal proceedings: the first is the enormous difference between the bargaining power of the two contracting parties; the second is the capacity of both parties to gain huge benefits through consensual solutions that externalize costs for other individuals or for society. In such circumstances, to approach these negotiations as if they were simple private transactions, in which agents have wide freedom to bargain informally, is a grave mistake with profound consequences. The informal nature of the process of negotiation and the lack of external oversight open

1365 As noted by Souza (n 132) 12 . 
an enormous window of opportunity for arbitrary practices and questionable maneuvers.

This subject did not go unnoticed by the German Federal Constitutional Court in in its decision on the constitutionality of negotiated judgments in criminal proceedings. Asserting that publicity was a key element for society's confidence in criminal prosecution, the German Federal Constitutional Court repeatedly stressed the importance of transparency and documentation rules for the development of a legitimate practice of negotiated solutions. ${ }^{1366}$ According to the court, the principle of publicity, as an expression of the constitutional notion of democracy, must allow the effective control of the resolution of criminal cases by agents not directly involved in the criminal procedure, inhibiting the introduction of authoritarian and arbitrary elements into the justice system. ${ }^{1367}$

Within this framework, the German Federal Constitutional Court asserted that robust monitoring of the negotiation practice within criminal procedure only occurs when society has access to all information related to the establishment and adequacy of a negotiated solution. ${ }^{1368}$ The duty of public authorities to document and accurately register the development of a negotiation with an accused party represents, thus, more than a mere formality, comprising a true constitutional guarantee. ${ }^{1369}$ In this context, the court concluded that an infringement of this guarantee generally entails the illegality of a negotiated solution. ${ }^{1370}$

From this perspective, the tolerant position of the Brazilian judiciary towards the highly informal nature of the negotiation of collaboration agreements is intolerable. Viewed correctly, the preparatory acts of collaboration agreements appear not as a simple bargaining process between private parties, but as fundamental stages of criminal prosecution against other agents. They must, therefore, be formally documented and precisely recorded, in order to enable a future assessment of the negotiation process by the judiciary and by society. Collaboration agreements transform defendants into a longa manus of law enforcement authorities, and it is of paramount importance to record when and how this partnership was established.

1366 See BVerfG, Urt. v. 19.3.2013 - 2 BvR 2628/10 u.a. = BVerfGE 133, 168, paras $7680,81,89,90$, among others.

1367 ibid para 88 .

1368 ibid para 89.

1369 ibid para 96.

1370 ibid para 97. 
Here again the Brazilian antitrust leniency program, which foresees a series of rules to ensure a minimum standard of formality and transparency, can provide some useful insights. As occurs in other leniency programs around the word, a central element of the Brazilian program is the marker system, which intends to guarantee an objective and transparent definition of the leniency beneficiaries. ${ }^{1371}$ According to this system, after receiving a leniency application, the Brazilian Antitrust Authority analyzes it and, if the statutory requirements are fulfilled, the applicant receives a formal document (the "marker") that proves that the application was submitted on that exact date and time, guaranteeing the place of the applicant in the "leniency race". ${ }^{1372}$ If another agent has already submitted a leniency application regarding that conduct, the applicant will be put in a "waiting line" and will receive a document registering the date and time she sought contact with the Antitrust Authority. ${ }^{1373}$ If the Antitrust Authority is already aware of the reported conduct, the applicant will be informed and may receive a marker for partial leniency. ${ }^{1374}$ In any case, the Antitrust Authority will always indicate a deadline for the submission of the relevant evidence and for the conclusion of the negotiations. ${ }^{1375}$ If for any reason the negotiation with the first applicant is unsuccessful, the next applicant in the waiting line will normally be contacted to negotiate a possible leniency agreement. ${ }^{1376}$

These kind of provisions have a lasting positive effect on the development of a sound policy regarding partnerships between law enforcement authorities and cooperating defenders. Firstly, they create a formal register of the preparatory acts that precede a leniency agreement, allowing for an effective control of the negotiation process in the future. They also make the negotiation process more objective and standardized, reducing the possibility of arbitrary and capricious negotiations. In view of some unwel-

1371 On the subject, see OECD, 'Use of markers in leniency programs', Working Party No. 3 on Co-operation and Enforcement, <http://www.oecd.org/officiald ocuments/publicdisplaydocumentpdf/?cote=DAF/COMP/WP3(2014)9\&doclan guage $=$ en $>$, accessed 4 March 2019.

1372 CADE (n 161) 26.

1373 ibid 28.

1374 ibid. 29.

1375 ibid. 31.

1376 ibid. 29. 
come occurrences in the practice of collaboration agreements, ${ }^{1377}$ the need for the adoption of similar rules in the criminal realm is more than clear.

\section{Governing through white-collar crime: collaboration agreements and the fight against corruption}

a. Collaboration agreements, the anti-corruption movement and the dynamic of "governing through crime"

The rewarded collaboration regulation, provided for in the Organized Crime Act, and the antitrust leniency program, established in the Competition Act, are often described as equivalent legal institutions with great similarities, two species of the same genus. ${ }^{1378}$ The practical development of each regulation reveals, however, enormous differences, since the antitrust leniency program was developed in accordance with the statutory rules, while the rewarded collaboration regulation has unfolded in a free bargaining zone. How could the Brazilian criminal justice system, traditionally founded on the concepts of strict legality, compulsory prosecution and search for truth, give rise to such an inventive practice of collaboration agreements, which appears extreme even by the standards of U.S. criminal procedure?

The framework of 'governing through crime' offers an interesting perspective to understand the idiosyncrasies and the unique characteristics of the inventive practice of collaboration agreements and its wide acceptance

1377 In a case with great repercussions in Brazilian society, it was revealed that the cooperating defendants apparently had received informal assistance from a federal prosecutor in order to negotiate and conclude their collaboration agreements. The defendants and the prosecutor were later indicted by the Federal Public Prosecution Office. According to the charges, "a federal prosecutor, member of the Car Wash Operation task force, was the strategist of the collaboration agreements." See the charges presented by the Federal Public Prosecution Office in the following proceeding: JFDF, AP 1011826-93.2018.4.01.3400 [2018], 24.

1378 Vinicius Gomes de Vasconcellos affirms that the collaboration agreement and the antitrust leniency agreement are "siblings". See Vasconcellos, Colaboração Premiada No Processo Penal (n 36) 31. In the same vein: Dino, 'A colaboração premiada na improbidade administrativa: possibilidade e repercussão probatória'(n 425) 533. 
by the Brazilian judiciary. ${ }^{1379}$ The pattern of "governing through crime" is nowadays well known as a concept that depicts the use of criminal law as a strategic instrument to legitimate the exercise of public authority in the pursuit of determined political goals. ${ }^{1380}$ Employed at first to describe how the "war on crime" became a central force in American political order and affected different aspects of U.S. public and private life, the concept has also been used to analyze the development of international criminal justice as a strategic tool in the realm of global governance. ${ }^{1381}$ In the field of corporate criminality and macro-delinquency, it has been noted that the model of "governing through crime" allows public authorities to generate enormous social impact, and achieve multiple objectives, through selective prosecution - occasional but extremely mediatized - of the highest business circles. ${ }^{1382}$

Some characteristics of the dynamics of "governing through crime" are quite straightforward in the recent Brazilian large-scale investigations of government and corporate criminality, which presented the main development field of the practice of collaboration agreements. While scrutinizing since 2014 the wrongdoings of the country's economic and political elite, the investigations aimed avowedly at a far more ambitious objective: the combat and eradication of so-called "systemic corruption". ${ }^{1383}$ In this context, the prosecution of some of the country's most prominent politicians

1379 On the concept of 'governing through crime', see Jonathan Simon, Governing Through Crime: How the War on Crime Transformed American Democracy and Created a Culture of Fear (Oxford University Press 2009).

1380 ibid 4-5.

1381 See Mark Findlay, Governing through Globalised Crime: Futures for International Criminal Justice (Routledge 2013). For an interesting analysis of concerns of legitimacy, fairness and due process regarding the modern regulation of transnational bribery law, see Kevin E. Davis, Between Impunity and Imperialism:The Regulation of Transnational Bribery (Oxford 2019).

1382 Hefendehl 'Außerstrafrechtliche und strafrechtliche Instrumentarien zur Eindämmung der Wirtschaftskriminalität' (n 12) 830-831.

1383 According to a report of the Office of the Federal Prosecutor General: "As of 2014, the Federal Public Prosecution Office begun to investigate the biggest corruption scheme in the Brazilian history (...) The investigation revealed the systemic corruption entrenched in the Brazilian political and economic system that spread among other countries". See: Ministério Público Federal, 'Relatório de resultados do Procurador-Geral da República: diálogo, unidade, transparência, profissionalismo, efetividade: 2015-2016' (2017) Gabinete do Procurador-Geral da República 13 <http://bibliotecadigital.mpf.mp.br/bdmpf/ handle/11549/109606> accessed 29 September 2019. See also: Sérgio F Moro, 'Preventing systemic corruption in Brazil' (2018) 147 Daedalus 57; Deltan Dal- 
and businessmen was portrayed not only as a response to individual wrongdoings, but as a wider movement to end the problems of impunity in the Brazilian justice system and change for better Brazilian society and democracy. ${ }^{1384}$

Based on the diagnosis that corrupt practices had become entrenched in political parties, business corporations and public organs, law enforcement authorities promoted and supported a broad range of initiatives dedicated to transform the "vicious circle of public and private corruption". ${ }^{1385}$ In

lagnol and Roberto Pozzobon, 'Ações e Reações No Esforço Contra a Corrupção No Brasil' in Maria Cristina Pinotti (ed), Corrupção: Lava Jato e Mãos Limpas (Portfolio-Penguin 2019). In the same vein, Ana Frazão and Ângelo Carvalho refer to corruption as a "structural problem of Brazilian society". Ana Frazão e Ângelo Carvalho 'Corrupção, cultura e compliance: o papel das normas jurídicas na construção de uma cultura de respeito ao ordenamento' in Ana Frazão and Ricardo Villas Bôas Cuevas (eds), Compliance: perspectivas e desafios dos programas de conformidade (Fórum 2018) 146.

1384 The recent anti-corruption investigations gave rise to high hopes for the enhancement of several aspects of Brazilian society. According to Luis Roberto Barroso: "The country has already changed and nothing will be as before. The immense demand for integrity, idealism and patriotism that exists today in Brazilian society is an inescapable reality. A seed has been planted. The train has already left the station. There are many images to illustrate the rebirth of the country over new foundations, both in public and in private ethics". See: Luis Roberto Barroso, 'Thirty Years of the Brazilian Constitution: The Republic That Is Yet to Be' (2018) SSRN Electronic Journal 1, 22. On the same note, Sergio Moro: "Hopefully, it will be possible to look back some years from now and say that Lava Jato made the national economy, the rule of law, and democracy stronger in Brazil”. See Moro (n 31) 166.

1385 According to the Federal Public Prosecution Office: "In Brazil, we see a vicious circle of public and private corruption. There is a warped and rationalizing culture in which, on one side, many accept the corruption as a way to do business while, on the other hand, public agents accept corruption because they were employed to 'guarantee a kickback from the one who put them there' or because they want to 'ensure their participation in the 'scheme" (...) To break the vicious circle that still exists in Brazil, the Federal Public Ministry (Federal Prosecution Office - MPF) is proposing some legislative changes". See: Ministério Público Federal, '10 medidas contra a corrupção - sumário executivo' 1 $<$ http://www.dezmedidas.mpf.mp.br/campanha/documentos/executive_summ ary_english_version.pdf $>$, accessed 17 July 2019. Armando Castro and Shaz Ansari note these efforts of Brazilian law enforcement authorities: "In our case, the agents involved in investigations decided to actively shape their context. Although they were able to investigate and arrest corrupt officials, they also attempted to try to change the law and norms in their favor. They openly campaigned to change laws and norms by collecting more than 2 million signatures for their proposals". See: Castro and Ansari (n 116) 8. 
this context, in 2016 an ambitious legislative proposal drafted by the Federal Public Prosecution Office attempted to set profound changes to Brazilian criminal, administrative and electoral law. ${ }^{1386}$ Among the proposed measures were the introduction of integrity tests for public servants, the inclusion of corruption in the list of heinous crimes, the restriction of the defendants' right to appeal, the establishment of new possibilities of pre-trial detention, and the enhancement of liability of political parties, with the provision of severe penalties - including the elimination of the party - for conducts of irregular campaign financing. ${ }^{1387}$

All these initiatives were highly publicized and received intense media coverage. ${ }^{1388}$ Robust marketing strategies, that relied on professional interface with the press, on the development of websites and on the use of social media, were conducted to promote the anti-corruption movement. ${ }^{1389}$ Through an active campaign coordinated by the Federal Public Prosecution Office, the 2016 legislative proposal against corruption garnered more than two million signatures before being examined by Congress. ${ }^{1390}$

Consequently, the prosecution of corruption and white-collar criminality has become, in recent years, an omnipresent issue in Brazilian public life, with multiple voices demanding a tougher response to the wrongdoings of political and economic elites. ${ }^{1391}$ This process bears numerous hallmarks of the pattern of "governing through crime", which depicts the en-

1386 For a general (and mainly critical) analysis of this attempt, see: Alaor Leite and Adriano Teixeira, Crime e Politica ( FGV Editora 2017).

1387 These proposals were dubbed "Ten Measures against Corruption". For a description, see: Ministério Público Federal (n 1386).

1388 A 2017 report of the Office of the Federal Prosecutor General highlighted this professional interaction with the media: "The website of the Car Wash Operation (www.lavajato.mpf.mp.br) contains the result of the activities of the members of the Institution. (...) The site has received more than 3 million visits. The professional interaction with the national and international press must be noted. In the last 24 months, the Institution has been inquired to answer 7.423 questionings of press media, radio and television networks, blogs and websites.” See Ministério Público Federal, 'Relatório de Resultados' (n 136), 13.

1389 Castro and Ansari (n 116) 8.

1390 Criticizing the lack of solid foundations of some of these proposals, Luis Greco observed that "the collection of signatures does not render arguments unnecessary" see Luís Greco, 'Reflexões Provisórias Sobre o Crime de Enriquecimento Ilícito' in Alaor Leite and Adriano Teixeira (eds), Crime e política: corrupção, financiamento irregular de partidos políticos, caixa dois eleitoral e enriquecimento ilícito. (FGV Editora 2017) 283.

1391 A 2019 report of Transparency International noted: "With Operation Carwash emerging and gaining strength since 2014 , corruption has become a central is- 
forcement of criminal law as a permanent combat or even as a war between enforcement authorities and powerful opponents. ${ }^{1392}$ Under these circumstances, law enforcement authorities gain a central position as guardians of the public interest, constantly using the media to speak out against impunity and alert society to the risks and losses caused by certain types of crimes. ${ }^{1393}$ The public pressure produced imposes a heavy burden upon the judiciary and erodes the power of courts, which are put in a defensive position and have to constantly prove their commitment to the fight against crime, ${ }^{1394}$ causing multiple impacts on the system of criminal justice, such as the increase in the level of criminal punishment and the disregard for legal nuances. ${ }^{1395}$

\section{b. Under the law, above the law}

This dynamics of 'governing through white-collar criminality' has led to a scenario where corruption and corporate crime have become centerpieces of Brazilian political and civil order, altering jurisprudential developments and shaping the legislative debate. Instead of relying on the fear of violent crime, this dynamic draws on the anger, frustration and resentment caused by the wrongdoings of economic and political elites to galvanize public opinion and gain massive support from different sectors of society. ${ }^{1396}$ In this highly attractive narrative, law enforcement authorities are the protagonists of a permanent fight against business cartels, corruption networks

sue for Brazilians”. See: Maxime Agator, 'Iraq: Overview of Corruption and Anti-Corruption' (2013) 374 U4 Expert Answer 1. For a strong defense of this response, see: Maria Cristina Pinotti, 'Corrupção, Instituições e Estagnação Econômica: Brasil e Itália' in Maria Cristina Pinotti (ed), Corrupção: Lava Jato e Mãos Limpas (Portfolio-Penguin 2019). Decisions of the Brazilian Federal Supreme Court also reveal this trend. See e.g. STF, AP 996 [2018] (Celso de Mello J) and STF, ADI 5874 MC [2018].

1392 Jonathan Simon, 'Governing Through Crime Metaphors', (2002) 67 Brooklyn Law Review 1035.

1393 ibid 43.

1394 ibid 35-36 and 168.

1395 Hefendehl, 'Außerstrafrechtliche Und Strafrechtliche Instrumentarien Zur Eindämmung Der Wirtschaftskriminalität' (n 12) 831-832.

1396 Jonathan Simon notes that the notion of a "war on crime" has a remarkable capacity to mobilize society, "striking a common chord of dread and despair" in different groups. See See Simon, 'Governing Through Crime Metaphors' (1393) 1064. 
and spurious pacts between corporations and political parties. Elected representatives, high-ranking public officials and businessmen represent the main antagonists, fulfilling the role of the inadmissible beneficiaries of an intrinsically fraudulent apparatus. Prosecution of governmental and corporate crimes becomes a central aspect of public life and is viewed as an essential tool for improving society's standard of living. ${ }^{1397}$

Throughout this process, the inventive practice of collaboration agreements and its consensual innovations have played a central role. Collaboration agreements concluded with high-ranking politicians and prominent executives have provided endless material confirming the assumption of a political system overrun by spurious interests. ${ }^{1398}$ The conversion of collaboration agreements into mechanisms of consensual resolution has replaced the long and tortuous course of factual determination with individual confessions, instantly and widely publicized. The complex distinction between criminal behavior and regular conduct, between offenders and innocents, has been overridden by a simple and loud message of widespread corruption. The application of the res inter alios acta principle has blocked any possibility for a serious and timely inquiry into the regularity of collaboration agreements and the veracity of cooperation reports.

In this context, it is clear that the objectives of recent large-scale investigations into macro-delinquency and of the inventive practice of collaboration agreements go far beyond the detection of serious wrongdoing and the imposition of criminal punishment. To achieve this end, the negotiation of collaboration agreements could and should have been developed in a very different manner, much more similar to the Brazilian antitrust leniency program and less detached from the rules established by the Organized Crime Act. As in other notorious investigations of white-collar crimes, the recent large-scale inquiries into Brazilian macro-delinquency have actually aimed at a far more ambitious goal: to restore, in a moment of severe social crisis, the trust of the general public, through the delivery of outcomes of symbolic nature. ${ }^{1399}$

The success of this effort requires the punishment of the organization's top brass, since the prosecution of individuals in low and mid-level pos-

1397 For such a position, see: Pinotti (n 1392) 53-76.

1398 See items II.2 and II.4.

1399 Analysing the symbolic function of economic criminal law and its role in the restoration of trust in capital markets in moments of crisis, see: Hefendehl, 'Enron, Worldcom Und Die Folgen: Das Wirtschaftsstrafrecht Zwischen Erfordernissen Kriminalpolitischen Erwartungen Und Dogmatischen Erfordernissen' (n 390) 19-21. 
itions is not enough to provide a persuasive answer to the social frustration caused by economic and political turmoil. In times of crisis, the strength of the symbolic message hinges on the imposition of severe penalties on the same individuals that profited the most during the years of prosperity. ${ }^{1400}$ The punishment of high-ranking figures conveys the message of active and functional public power and reaffirms the ideal that all individuals, regardless of their social position and personal wealth, are subject to the law and can be brought to justice.

The establishment of criminal liability of these individuals faces, however, numerous difficulties. ${ }^{1401}$ Corporate and government crimes are normally implemented through bureaucratic routines, inserted in the ordinary functioning of regular organizations, and often there is no clear difference between regular conduct and illegal practices. ${ }^{1402}$ Furthermore, the execution of complex criminal strategies occurs through separate acts committed by several agents at different times and different places. ${ }^{1403}$ Due to the structural complexity of legitimate organizations, it can be very difficult to associate the commitment of serious wrongdoings with the individual behavior of the organization's top brass. ${ }^{1404}$

In the clash between the need to hold high-ranking figures accountable and the difficulty in establishing their criminal conduct, the loosening of traditional standards of criminal law and standard pillars of criminal procedure constitutes an obvious path. ${ }^{1405}$ Corruption networks assume here the same role that terrorist and mafia organizations have played elsewhere: they provide a palatable justification to empower public authorities and relax individual safeguards in an alleged war between society and dangerous enemies. ${ }^{1406}$ The inventive practice of collaboration agreements appears here not as an isolated event, but as part of a wider legal movement to expand the powers of law enforcement authorities and to enable greater flexibility within the apparatus of state prosecution. One can only note the subtle irony engendered by this movement: in order to attest that powerful

1400 ibid, 22.

1401 See section II.3.

1402 See item II.3.b.

1403 Shapiro (n 366) 354.

1404 Wheeler and Rothman (n 370).

1405 For a similar critique, but regarding the use by the Brazilian Federal Supreme Court of the theory of dominion of the act ("Tatherrschat") in the investigation of corruption, see: Greco and Leite (n 17) 290-292.

1406 Observing this scenario in relation to terrorism and organized crime, see: Hörnle (n 803) 333 and 351-353. 
politicians and businessmen are under the law, it must release state authorities from multiple legal constraints and place them above substantive and procedural legality.

c. Investigative achievements, failures and the effectiveness discourse: collaboration religion?

Confronted with critical analyses, the supporters of the Brazilian practice of collaboration agreements, besides resorting to the misleading association with the ideal of consensual justice, normally point out to an undisputed fact: through the design of bold consensual arrangements with offenders, law enforcement authorities have achieved fast and visible outcomes in the prosecution of macro-delinquency. ${ }^{1407}$ Over recent years, collaboration agreements have indeed played a major role in the prosecution and punishment of high-ranked politicians and businessmen, that stands in sharp contrast to the slow pace and image of impunity associated with the normal functioning of Brazilian criminal justice, especially in the field of government and corporate criminality.

Although there are several important concerns regarding the recent investigations of macro-delinquency in Brazil, one aspect should disturb even the biggest enthusiast for effective criminal solutions: the propensity of the Brazilian practice of collaboration agreements to mislead official investigations, generate erroneous results, produce severe losses and put law enforcement authorities in unexplainable, if not embarrassing, positions.

In 2015, the Brazilian Federal Supreme Court, based on evidence brought by a cooperating defendant, determined the preventive detention of one of Brazil's most prominent bankers, who was allegedly involved in a witness tampering scheme. ${ }^{1408}$ The main piece of evidence was a meeting secretly recorded by the cooperator in which the banker, who was not present, was cited as a purported financier of the alleged scheme. In spite of the lack of more substantial evidence, he remained almost one month in preventive custody and almost four months under house arrest. The investigation caused billions of losses in the stock market, forced some major business divestments and even affected the value of the Brazilian curren-

1407 See e.g. Sarmento (n 35) 452; Kurtenbach and Nolte (n 16) 5.

1408 See STF, AC 4036 [2015]. 
cy. ${ }^{1409}$ In 2017, after the conclusion of the investigations, the Federal Public Prosecution Office asked for the acquittal of the banker, alleging that the collected evidence was insufficient for his conviction. ${ }^{1410}$ The judicial decision acquitted him and asserted that the evidence provided by the cooperator was dubious and open to multiple interpretations, including that the cooperator wanted to extort financial compensation from the banker. ${ }^{1411}$

In 2016, a cooperator provided evidence that allegedly indicated the existence of a sophisticated plot to obstruct the progress of criminal investigations related to the corruption of public officials. ${ }^{1412}$ Given that the cooperator had secretly recorded private conversations with several high-ranked politicians, such as a former President of the Republic and a former President of the Senate, the investigation attracted massive media attention and had substantial political consequences, including the resignation of two Brazilian government ministers. ${ }^{1413}$ The conclusion of the official investigations showed once again a different scenario than that presented previously by the cooperator. In 2017, an extensive report of the Brazilian Federal Police rejected the version that the accused had committed any crime, affirmed that the cooperator had tried to instigate criminal behavior and suggested that, due to the inefficacy of the collaboration agreement, no benefits should be granted to the cooperator. ${ }^{1414}$ Not long after that, the

1409 For a description of the arrest and its financial impacts, see Donna Bowater, 'The arrest of a 'genius' leaves Brazil's banks fighting for reputation' The Telegraph (London, 12 December 2015) <https://www.telegraph.co.uk/finance/glob albusiness/12047673/The-arrest-of-a-genius-leaves-Brazils-banks-fighting-for-rep utation.html> accessed 19 September 2018; Vinod Sreeharsha, 'Brazil's 'better than Goldman' bank slowly rebounds from scandal' VInod Sreeharsha, 'Brazil's 'better than Goldman' bank slowly rebounds from scandal' (2016) The New York Times (New York, 5 September 2016) <https://www.nytimes.com/201 6/09/06/business/dealbook/brazils-better-than-goldman-bank-slowly-rebounds-f rom-scandal.html> accessed 20 February 2019.

1410 See the allegations presented by the Federal Public Prosecution Office in the following proceeding: JFDF, AP 42543-76.2016.4.01.3400 [2016].

1411 See the verdict of $12 / 6 / 2018$ in the following proceeding JFDF, AP 42543-76.2016.4.01.3400 [2016].

1412 See STF, Collaboration Agreeement of J.S.O.M [2016].

1413 See Simon Romero, 'Recording spurs anticorruption minister to resign in Brazil' The New York Times (New York, 30 may 2016) <https:/www.nytimes.co $\mathrm{m} / 2016 / 05 / 31 /$ world/americas/brazil-fabiano-silveira-resign.html $>$ accessed 20 February 2019.

1414 See the analysis report provided by the Brazilian Federal Police: STF, INQ 4367 RAPJ 76 DICOR/PF [2017] 
Federal Prosecution Office suggested the closure of the investigations without pressing any formal charges, which was accepted by the Federal Supreme Court. ${ }^{1415}$

The most controversial case of the Brazilian practice of collaboration agreements occurred in 2017. ${ }^{1416}$ After signing the first agreement in which the Federal Public Prosecution Office agreed to no press any charges, businessmen-turned-cooperators provided material that supposedly proved the involvement of almost two thousand politicians in corruption schemes. A central piece of evidence was a secretly recorded meeting between one cooperator and the President of the Republic, in which negotiations were allegedly made to buy the silence of another defendant. ${ }^{1417}$ The disclosure of the agreement naturally had enormous impacts on Brazilian political life and presented an ostensible investigative achievement that, for a moment, appeared to vindicate the idiosyncrasies of the practice of collaboration agreements.

However, four months after the disclosure of the agreement, a major and unexpected plot twist occurred: the development of the investigations revealed the existence of a recording of private conversations between the cooperators that had not been previously submitted to the law enforcement authorities. ${ }^{1418}$ Apparently made by accident and lasting several hours, the unintended recording seemingly indicated the existence of important omissions and distortions in the cooperation report, causing a major shift in the investigations, with serious repercussions for several agents. The cooperators had their benefits suspended and were put under preventive custody, which lasted several months. ${ }^{1419}$ In a concomitant investigation, they were also accused of engaging in insider trading at the time of the disclosure of the collaboration agreement, allegedly using the privileged information on the agreement to maneuver the stock market and

1415 See STF, INQ 4367 [2017].

1416 See STF, PET 7003 [2017].

1417 See Dom Phillips, 'Brazil President Endorsed Businessman's Bribes in Secret Tape, Newspaper Says' The New York Times (New York, 17 may 2017) <https:// www.nytimes.com/2017/05/17/world/americas/brazil-michel-temer-joesley-bati sta-corruption.html $>$ accessed 18 February 2019.

1418 See 'Brazilian tycoon arrested after lawyers send prosecutors the wrong tape' BBC News (London, 10 September 2017) <https:/www.bbc.com/news/world-la tin-america-41222400> accessed 17 September 2018.

1419 See David Meyer, 'JBS's Batista brothers arrested as Brazil corruption probes spiral' (2017) Fortune (New York, 14 September 2017) <https://fortune.com/20 17/09/14/jbs-batista-brazil-temer-corruption-insider-trading/> accessed 17 September 2018. 
avoid losses. ${ }^{1420}$ After an inquiry into the negotiation process of the collaboration, two of the cooperators' lawyers were later charged by the Public Prosecution Office with corruption. ${ }^{1421}$ In 2018, the business conglomerate owned by the cooperators filed, alleging professional malpractice, a civil law suit seeking compensatory and punitive damages from the international network of law firms that negotiated the collaboration agreement. ${ }^{1422}$

These and other events indicate that the picture of effectiveness painted by enthusiasts of collaboration agreements seems quite controversial. If, on the one hand, the practice of agreements has led to fast and visible results regarding the prosecution and punishment of corporate and government crimes, on the other it has led to remarkable mistakes and caused enormous social losses. But comparison between the much-vaunted investigatory achievements and the downplayed failures is a misleading path to properly assess the effectiveness of a leniency policy, which always engenders a complex dynamic with multiple, long-lasting and often contradictory impacts. ${ }^{1423}$

The enhancement of deterrence, a central goal of any leniency policy, can only be assessed through a much more detailed empirical study, which analyzes in a comprehensive manner the multifaceted effects of the development of the practice of collaboration agreements. ${ }^{1424}$ In the Brazilian reality, this study would necessarily consider the different consensual innovations designed by legal practitioners, which allow for greater benefits and much milder sentences for cooperators than provided for in the statutory regulation of the Organized Crime Act. To date, there has been no known attempt to develop such a study.

Put under a more thorough examination, it becomes clear that the alleged effectiveness of the practice of collaboration agreements has no con-

1420 See Andres Schipani and Joe Leahy, 'Brazil prosecutors charge JBS owners with insider trading' Financial Times (London, 10 October 2017) $<$ https://www. ft.com/content/8079516d-1a47-3e5d-a8d7-0aa488a39832> accessed 18 September 2018.

1421 See the charges presented by the Federal Public Prosecution Office in the following proceeding: JFDF, AP 1011826-93.2018.4.01.3400 [2018].

1422 'J\&F sues law firms Trench, Rossi \& Watanabe and Baker \& Mackenzie' Valor International (São Paulo, 12 April 2018) <https://www.valor.com.br/internation al/news/5445917/jf-sues-law-firms-trench-rossi-watanabe-and-baker-mackenzie> accessed 12 May 2019.

1423 On the expectations and risks associated with the use of leniency policies, see chapter III.

1424 See Marvão and Spagnolo (n 32) 116. See also Stephan and Nikpay (n 527) 546. 
nection to a straightforward increase in overall deterrence, relying on a set of convictions - limited but with enormous media coverage - of highranked businessmen and prominent politicians. In other words, the effectiveness discourse stems from a narrow, selective and self-interested approach rather than from an objective, wide-ranging and detached analysis. In this respect, the standard approach to the Brazilian practice of collaboration agreements is by no means different from the deferential treatment normally given to leniency policies in competition law. As Caron Y. Beaton-Wells has precisely described, this approach - inward-looking, shortsighted, uncritical, overconfident and universalist - bears several hallmarks of a religious belief. ${ }^{1425}$

Once the effectiveness discourse is deconstructed, the real backbone of the practice of collaboration agreements emerges more clearly: the enormous strength of the symbolic message that spreads through society when prominent individuals are prosecuted and eventually sentenced to harsh imprisonment penalties. The Brazilian experience clearly demonstrates the communicative power of this message. In a society entangled in a long-lasting public security crisis and simultaneously confronted with its worst ever economic recession, the ideal of a sweeping and severe investigation of 'systemic corruption' and macro-delinquency arose not just as a response to wrongful individual behavior, but to perform the much more ambitious function of recovering the impaired trust of society in the political and economic system.

The imposition of severe imprisonment penalties on a few members of the elite - presumably responsible for the deplorable state of affairs - creates compelling images with a tremendous impact on society, spreading a vigorous message of an effective fight against impunity. ${ }^{1426}$ In this scenario, high-ranked politicians and businessmen must be portrayed as very powerful public enemies, who ought to be subdued at any cost. ${ }^{1427}$ Once this battle is won, society can move forward with high hopes for a bright new dawn.

1425 Beaton-Wells (n 33) 129 and 165-169. See also: Beaton-Wells (n 448).

1426 For a good analysis of this point, see Hefendehl, 'Außerstrafrechtliche Und Strafrechtliche Instrumentarien Zur Eindämmung Der Wirtschaftskriminalität' (n 12) 830 and 846-847.

1427 Roland Hefendehl speaks of a "criminal law of the enemy" in the field of economic criminal law. See Hefendehl, 'Corporate Governance Und Business Ethics: Scheinberuhigung Oder Alternativen Bei Der Bekämpfung Der Wirtschaftskriminalität?' (n 541) 120. 
d. The symbiotic relationship between collaboration agreements and the Brazilian anti-corruption movement

When compared to other investigate tools used in the prosecution of corporate crimes, leniency policies display a central advantage in the context of "governing through crime": they generate evidence that is effortlessly explainable for a mass audience. The Brazilian practice of collaboration agreements generated hundreds of hours of videotaped depositions. Secretly recorded meetings showed the intimate relationships between the political and economic elites. Internal spreadsheets listed names, suspicious pseudonyms and huge amounts of money. The material provided by cooperators was highly visual and easy to communicate, spawning a body of cultural products - such as books, movies and TV series - which, together with the daily media coverage, disseminated and entrenched the idea that corruption was the nation's central problem. ${ }^{1428}$

The judicial support for the early exposure of collaboration agreements, contradicting the confidentiality regime established by the Organized Crime Act, was essential for the development of this dynamic. ${ }^{1429}$ The prompt disclosure of cooperating reports and the provided evidence had immediate effects on Brazilian political and economic life, even though some reports never led to a criminal conviction and a few proved to be deceptive and even fanciful.

The development of package deals, which established a single penalty for all the wrongdoings confessed by the cooperator, stimulated the admission of a multitude of conducts. ${ }^{1430}$ Given that the overall punishment was already defined, the incentive for cooperators was to include in their report as much conduct as possible. The constant conception of new benefits allowed the design of consensual arrangements that were much more attractive than the system of agreements provided for in the Organized

1428 As noted by Armando Castro and Shaz Ansari: "The press coverage of the Car Wash operation has received by far the largest corruption coverage in recent Brazilian history. Car Wash's general popularity was greatly increased during the campaign, and the whole country became aware of the investigation and some of the main suspects. In 2015, corruption began to be perceived as the most significant problem in Brazil, indicating a change of priorities concerning key issues for the Brazilian people”. See Castro and Ansari (n 116) 7.

1429 See item V.2.e

1430 On the development of package deals in the practice of collaboration agreements, see item I.4.a.iii. 
Crime Act. ${ }^{1431}$ The motto "when in doubt, confess" never seemed so appropriate. ${ }^{1432}$

The field of corporate and government criminality represented fertile soil for the proliferation of collaboration agreements, especially in the realm of campaign finance, where problems of corruption and the appearance of corruption are ubiquitous. ${ }^{1433}$ In a scenario where criminal legislation is vague and comprehensive and the distinction between regular activities and criminal behavior depends strongly on circumstantial evidence and subjective elements, the use of consensual arrangements as hedging mechanisms thrived. ${ }^{1434}$ The lack of any effective judicial control and the disregard for basic principles of Brazilian criminal procedure, such as compulsory prosecution and strict legality, fostered and consolidated this type of transaction. The combination of these elements guaranteed a constant positive feedback loop for criminal investigations and turned the prosecution of macro-delinquency and corruption into a never-ending story.

In this light, the bold practice of collaboration agreements reveals a symbiotic relationship with the recent anti-corruption movement in Brazil. The early disclosure of confessions and material brought by agreements ensured constant fuel for the movement, while the widespread popularity and enormous social appeal of the anti-corruption cause outflanked any attempt to judicially control the consensual innovations developed by law enforcement authorities and cooperating defendants. ${ }^{1435}$ Generous and flexible collaboration agreements incessantly - and instantaneously - revealed an image of systemic corruption; the diagnosis of systemic corruption justified the necessity of generous and flexible agreements.

1431 See item I.4.a.i

1432 Ian Forrester and Pascal Berghe, analyzing the European antitrust leniency policy, state that: "When in doubt, confess' could be the motto of the leniency policy”. See Forrester and Berghe (n 566) 172.

1433 Recognizing these problems, see.: Samuel Issacharoff and Pamela S Karlan, 'The hydraulics of campaign finance reform,' 77 Texas Law Review 1705.

1434 On the use of collaboration agreements as hedging mechanisms, see V.4.b.

1435 As noted by Simon, "The judiciary in an era of crime is on the defensive and anxious to demonstrate that it is not a source of criminal risk to victims".. See Simon, 'Governing Through Crime' (1380) 68. 


\section{Conclusion: a prosperous life for consensual mechanisms in Brazilian criminal justice}

It has been noted that the dynamic of 'governing through crime' has redesigned the American urban environment, replacing old neighborhoods with new landscapes in the pursuit of safer streets. ${ }^{1436}$ Similarly, the process of 'governing through white-collar crime' has profoundly reshaped the Brazilian political and corporate environment, in an extensive and omnipresent quest for honesty and integrity. Leniency policies have played a major role throughout this process, generating a constant positive feedback loop for criminal investigations and underpinning the diagnosis of systemic corruption. In the complex context of relationships between economic and political power, the flexible and indiscriminate use of collaboration agreements has constructed a perpetual-motion machine of accusations, with major repercussions on Brazilian public life.

In the 2018 general elections, the combat of "systemic corruption" became a central topic of political debate. ${ }^{1437}$ Faced for years with a solid narrative of widespread corruption within Brazil's elite, the electorate decided for a massive change in political representation. Traditional political parties suffered major defeats and a wide anti-establishment movement proved to be extremely successful. ${ }^{1438}$ Seat turnover in the two houses of

1436 Simon, 'Governing Through Crime Metaphors', (n 1393) 1068.

1437 The international press has noted this aspect of the 2018 Brazilian elections. According to a report, the massive corruption investigations had direct electoral impacts: "The effect on public opinion has been devastating: According to Gallup, just 17 percent of Brazilians have confidence in their national government, a decline from 51 percent just a decade ago. During the first round, 47 politicians charged with corruption or who were currently under investigation were defeated in re-election bids."

See José R. Cárdenas, 'The sad decline of Brazil's political establishment' Foreign Policy (Washington, 19 October 2018) <https://foreignpolicy.com/2018/10/ 19/brazil-bolsonaro/> accessed 2 May 2019. See also RJ Reinhart, 'Brazilians face confidence crisis ahead of election' Gallup News (Washington, 27 September 2018 ) <https://news.gallup.com/poll/243161/brazilians-face-confidence-crisi s-ahead-key-election.aspx? > accessed 3 June 2019.

1438 Regarding the recent debacle of the Brazilian political elite, see Kenneth Raposa, 'Brazil's elite have fallen to pieces' Forbes (New York, 14 September 2017) <https:/www.forbes.com/sites/kenrapoza/2017/09/14/brazils-elite-have-fa llen-to-pieces/> accessed 4 October 2018; Anthony Faiola and Marina Lopes, 'In Brazil's election, the traditional political class is wiped out' The Washington Post (Washington, 8 October 2018) <https://www.washingtonpost.com/world/t he_americas/in-brazils-election-the-traditional-political-class-is-wiped-out/2018/ 
Congress reached its highest rate in recent decades. ${ }^{1439}$ Candidates seen as political outsiders obtained major victories in electoral disputes for governmental and legislative positions. The promise of a tougher response on crime, particularly on corruption and white-collar criminality, was a major driving force of this sweeping change in Brazilian politics.

Given the symbiotic relationship between the bold practice of collaboration agreements and the anti-corruption movement, one can only expect consensual innovations to become more and more commonplace in Brazilian criminal law. Multiple signals already point in this direction: after experimenting with the benefits of resolving complex criminal investigations through collaboration agreements, legal practitioners nowadays seem to be constantly expanding the negotiation forum within criminal procedure through contra or praeter legem transactions, particularly in the field of white-collar criminality. Furthermore, recent legislative proposals seek to endorse the enlargement of the scope for consensual solutions within Brazilian criminal procedure. ${ }^{1440}$ Since inter-party negotiations have become associated not only with the ideal of speedier justice but also with the objective of prosecuting powerful defendants, consensual solutions appear to be at the beginning of a long and prosperous life in Brazilian criminal law.

If this forecast is right, the rewarded collaboration regulation may prove to be just a 'gateway drug' in the realm of consensual solutions within Brazilian system of criminal justice. ${ }^{1441}$ In view of the immediate and dazzling results brought by consensual mechanisms, the defense of basic pil-

10/08/17d00ee8-ca8f-11e8-ad0a-0e01efba3cc1_story.html> accessed 4 June 2019.

1439 See 'Eleições: Senado tem a maior renovação da sua história' Agência Senado (Brasília, 8 October 2018) <https://www12.senado.leg.br/noticias/materias/201 8/10/08/eleicoes-senado-tem-a-maior-renovacao-da-sua-historia $>$ accessed 4 May 2019; 'Câmara tem renovação de quase 50\% na nova legislatura' Câmara dos Deputados (Brasília, 23 January 2019) <https://www.camara.leg.br/noticias/5509 32-camara-tem-renovacao-de-quase-50-na-nova-legislatura/> accessed 3 October 2019.

1440 In February 2019, the Brazilian government submitted a legislative proposal to the Congress to enhance the prosecution of corruption, organized crime and violent offenses. The proposed measures contained two new forms of consensual mechanisms for resolution of criminal cases.

1441 According to Martin Heger and Robert Pest, the introduction of section $₫ 153 \mathrm{a}$ in the German Code of Criminal Procedure, which established possibilities for the consensual resolution of cases of minor offenses, is often described as a 'gateway drug' ("Einstiegsdroge") for the practice of negotiated judgments. See Heger and Pest (n 37) 449. See item IV.2.b. 
lars of Brazilian criminal procedure - such as compulsory prosecution, strict legality and separation of functions - seems outdated and obsolete. Amidst self-interested legal practitioners and with public opinion eager for further expedite outcomes, collaboration agreements could very well represent the perfect Trojan horse and lead to the dissemination of a party-driven model of criminal process within a system of official investigation. ${ }^{1442}$

This dynamic of 'Americanization' of Brazilian criminal procedure could have far-reaching consequences and comparative legal analysis can offer a useful toolkit to monitor these developments. Given the high incentives for legal practitioners to resolve criminal cases through settlements that externalize costs, and without any effective constraint coming from courts committed to the dynamics of 'governing through white-collar criminality', legal scholarship has a very important task to fulfill, critically assessing judicial practice, raising red flags in cases of 'legal counterfeits ${ }^{1443}$ and proposing a more accurate, equitable and transparent model of negotiation within Brazilian criminal justice.

1442 Analyzing the American model of plea bargaining as a Trojan horse of the party-driven system, see Langer (n 28) 35-39.

1443 On legal transplants and legal counterfeits, see Greco and Leite (n 17) 292. See also item V.3.d. 


\section{Conclusion}

For a long time, large-scale use of cooperating defendants in criminal investigations has been a distinctive feature of the U.S. criminal justice system, whose party-driven model of criminal procedure allows for multiple types of transactions between law enforcement authorities and accused. Over recent decades, this scenario has changed substantially, since a large number of countries have adopted legal reforms that authorize the granting of benefits to defendants who assist law enforcement authorities in the prosecution of former accomplices. Leniency policies have become nowadays a common mechanism around the world, raising important legal questions and causing some bewilderment, particularly in jurisdictions of Continental tradition that understand criminal procedure as an official investigation, and not a dispute between two parties.

In Brazil, the 2013 Organized Crime Act introduced the rewarded collaboration regulation and designed a communication forum allowing enforcement authorities and accused to negotiate and close written agreements. After that, the use of cooperating defendants has evolved rapidly, especially in the prosecution of corrupt practices and corporate malpractice, turning the negotiation of collaboration agreements into a common routine in Brazilian criminal justice.

The legal practice of the rewarded collaboration evolved in a highly inventive manner leading to several innovations that are not established by the Organized Crime Act. Over the years, legal practitioners drew on the rewarded collaboration regulation to establish a comprehensive system of transactions and expanded the negotiation forum well beyond its statutory boundaries. Instead of abiding by the model of simple exchanges established in the Organized Crime Act, procedural participants formulated sophisticated tailor-made arrangements that regulated a wide array of matters and devised customized solutions. Through collaboration agreements concluded at early stages of criminal investigations, defendants and prosecutors established exact imprisonment penalties and created "package deals", defining a single punishment for a wide range of confessed crimes. Collaboration agreements also established benefits not provided for by law, such as the design of "differentiated" detention regimes that allow the serving of long sentences in private residences, the protection of personal assets from 
the rules of legal seizure and the granting of preferential treatment to the cooperator's family members.

Faced with the audacious innovations brought by inter-party arrangements, the Brazilian judiciary chose to give strong support to the inventive practice of collaboration agreements. Adopting a 'contractualist' approach to interpret the rewarded collaboration regulation, courts - following guidelines fixed by the Brazilian Federal Supreme Court - applied principles and doctrines of private contract law to resolve disputes regarding the use of collaboration agreements. In this context, traditional concepts of private law - such as the "res inter alios acta" principle and the rule of "pacta sunt servanda" - became central elements to substantiate a model of transaction that confers great negotiative freedom upon the procedural participants. From this perspective, the Brazilian judiciary understood that collaboration agreements negotiated by prosecutors and cooperating defendants have no effect upon other accused, who lack the right to question the regularity of the consensual arrangements in court. It also affirmed that collaboration agreements have a binding effect on sentencing by judicial bodies, who must respect the terms set by the parties.

The contractualist approach to collaboration agreements has had major impacts on Brazilian criminal justice. It fostered a system of negotiation in which cooperating defendants can predefine, through written agreements concluded even before the existence of a formal indictment, the exact imprisonment punishment and the conditions under which it is served. It allowed the contractual redesign of Brazilian criminal law through the constant invention of new rights and obligations. It also authorized cooperating defendants to serve imprisonment penalties in advance, before the judicial pronouncement of the verdict and sentence and sometimes even before the opening of a formal proceeding.

This thesis has offered a critical assessment of the Brazilian practice of collaboration agreements and rejected the contractualist approach to the rewarded collaboration regulation. Drawing lessons from the German experience with the crown-witness regulation and with the practice of negotiated judgments, it asserted that collaboration agreements are fact-finding tools for situations of investigative emergencies, and not mechanisms for the consensual resolution of criminal cases. As in Germany, the use of cooperating defendants in Brazil does not appear as an aspect of the parties' broad capacity to dispose of criminal procedure, but rather represents an exceptional measure to overcome otherwise unsurmountable obstacles in the prosecution of serious crimes. Like the German crown-witness regulation, Brazilian collaboration agreements constitute devices for ensuring 
the effective collection of evidence and adequate fact-finding in scenarios of investigative emergencies. As an extraordinary reaction to extraordinary circumstances, collaboration agreements must strictly observe the limits set by the Organized Crime Act. Beyond these limits, procedural participants lack the capacity to negotiate and close consensual arrangements.

The thesis has rejected the concept that collaboration agreements are simple bilateral transactions and the association of these mechanisms with the ideal of a new form of "consensual criminal justice". Instead, the thesis proposed that the rewarded collaboration regulation represents - like other leniency policies - a form of privatization of investigative and prosecutorial activities. Collaboration agreements transfer to private agents - the offenders - a portion of the activities of gathering, screening and organizing the relevant information and evidence for the prosecution of criminal organizations. These agreements can be understood as public-private partnerships within the apparatus of state prosecution, in which defendants and enforcement authorities establish a durable and stable relationship directed at the successful prosecution of other offenders.

As in other fields, the development of public-private partnerships can bring benefits for the activities of law enforcement authorities, reducing the costs of detecting serious crimes and enhancing instability within criminal organizations. On the other hand, these partnerships generate multiple risks, which arise from the difference between the objectives pursued by public authorities and cooperating defendants and from the informational asymmetry that exists between them. The investigative joint ventures engendered by collaboration agreements have the structure of a principal-agent relationship, creating several opportunities for cooperating defendants to misrepresent facts, obtain excessive benefits and strategically exploit the rewarded collaboration regulation.

From this perspective, the thesis criticized the enormous deference showed by the Brazilian judiciary, particularly by the Federal Supreme Court, towards the inventive practice of collaboration agreements, and contrasted it with the position of the German Federal Constitutional Court regarding the constitutionality of negotiated criminal judgments. Confronted with a scenario of pervasive disregard of legislative regulations by legal practitioners, the German Constitutional Court restricted the transactions between procedural participants to the boundaries set by statute, expressly rejecting the concept of consensual criminal justice and affirming that consensual arrangements must respect the state's commitment to search for truth, the principle of individual guilt and the duty of transparency and documentation. 
Faced with a similar situation, the Brazilian Federal Supreme Court invoked concepts of private contract law to block legal actions by third parties affected by collaboration agreements, prevent adequate judicial control of the practice and validate extravagant transactions, revealing a deference to consensual arrangements in criminal procedure that is extreme even by the loose standards of the U.S. experience. The contractualist approach allowed the use of collaboration agreements as hedging mechanisms and led to an astonishing phenomenon: the redesign of Brazilian criminal law through consensual arrangements.

Over the last years, collaboration agreements generated much vaunted results in the investigation of corrupt practices and corporate wrongdoings, gaining enormous attention. This thesis has pointed out a less prominent facet of the practice of collaboration agreements: its propensity to mislead official investigations, generate erroneous results and produce severe social losses. As well as effective outcomes in the prosecution of macro-delinquency, the massive use of collaboration agreements in recent years generated examples to fill every chapter of a textbook about the risks of leniency policies. Misrepresentation of facts, granting of unfounded advantages to leniency beneficiaries, overreliance of enforcement authorities on cooperating reports and reverse exploitation of the leniency system: all can be found in the Brazilian experience with collaboration agreements.

In its final remarks, the thesis associated the blossoming of the practice of collaboration agreements with the dynamics of "governing through white-collar crime", in which the prosecution of macro-delinquency constitutes a central tool to restore, in times of severe social crisis, public trust in the economic and political system through the delivery of symbolic results. Viewed from this perspective, the inventive practice of collaboration agreements appears not as an isolated event, but as part of a wider movement to loosen traditional guarantees of criminal procedure and criminal law, curbing judicial control and allowing enforcement authorities to obtain spectacular victories in an alleged war between society and powerful enemies. 


\section{Annex - List of collaboration agreements analyzed}

\begin{tabular}{|c|c|c|c|c|c|}
\hline No. & Name $(*)$ & $\begin{array}{l}\text { Date of the } \\
\text { agreements' } \\
\text { conclusion }\end{array}$ & $\begin{array}{l}\text { Date of judi- } \\
\text { cial homolo- } \\
\text { gation }\end{array}$ & $\begin{array}{c}\text { No. of the proceeding in } \\
\text { which the agreement got } \\
\text { validated }\end{array}$ & $\begin{array}{l}\text { Court respon- } \\
\text { sible for ho- } \\
\text { mologation } \\
\quad(* *)\end{array}$ \\
\hline 1 & P. C. & $27 / 08 / 2014$ & $29 / 09 / 2014$ & Pet 5209 & STF \\
\hline 2 & A. B. & $16 / 09 / 2014$ & - & $5025676-71.2014 .404 .7000$ & JFPR \\
\hline 3 & H. M. & $16 / 09 / 2014$ & - & $5025676-71.2014 .404 .7000$ & JFPR \\
\hline 4 & M. L. & $16 / 09 / 2014$ & - & $5025676-71.2014 .404 .7000$ & JFPR \\
\hline 5 & S. B. & $16 / 09 / 2014$ & - & $5025676-71.2014 .404 .7000$ & JFPR \\
\hline 6 & J.C. & $22 / 10 / 2014$ & $10 / 11 / 2014$ & 5073441-38.2014.404.7000 & JFPR \\
\hline 7 & A. N. & $22 / 10 / 2014$ & $10 / 11 / 2014$ & $5073441-38.2014 .404 .7000$ & JFPR \\
\hline 8 & P.F. & $19 / 11 / 2014$ & $05 / 12 / 2014$ & $5075916-64.2014 .404 .7000$ & JFPR \\
\hline 9 & A. Y. & $24 / 09 / 2014$ & $19 / 12 / 2014$ & Pet 5244 & STF \\
\hline 10 & S. N. & $06 / 02 / 2015$ & $19 / 03 / 2015$ & $5007089-64.2015 .404 .7000$ & JFPR \\
\hline 11 & L. N. & $06 / 02 / 2015$ & $19 / 03 / 2015$ & $5007089-64.2015 .404 .7000$ & JFPR \\
\hline 12 & J. N. & $06 / 02 / 2015$ & $19 / 03 / 2015$ & $5007089-64.2015 .404 .7000$ & JFPR \\
\hline 13 & D. A. & $27 / 02 / 2015$ & $30 / 03 / 2015$ & $5013949-81.2015 .404 .7000$ & JFPR \\
\hline 14 & R. L. & $03 / 12 / 2014$ & $29 / 04 / 2015$ & Pet 5589 & STF \\
\hline 15 & E. L. & $27 / 02 / 2015$ & $23 / 05 / 2015$ & $5012994-50.2015 .404 .7000$ & JFPR \\
\hline 16 & R. P. & $13 / 05 / 2015$ & $23 / 06 / 2015$ & Pet 5624 & STF \\
\hline 17 & M. P. & No date & $29 / 06 / 2015$ & $5030136-67.2015 .404 .7000$ & JFPR \\
\hline 18 & J. P. & No date & $29 / 06 / 2015$ & $5030825-14.2015 .404 .7000$ & JFPR \\
\hline 19 & H. J. & No date & $28 / 07 / 2015$ & $5035348-69.2015 .404 .7000$ & JFPR \\
\hline 20 & M. G. & $27 / 07 / 2015$ & $30 / 07 / 2015$ & $5037272-18.2015 .404 .7000$ & JFPR \\
\hline 21 & R. T. & $12 / 06 / 2015$ & $04 / 08 / 2015$ & $5032688-05.2015 .404 .7000$ & JFPR \\
\hline 22 & R. M. & $12 / 06 / 2015$ & $04 / 08 / 2015$ & $5032694-12.2015 .404 .7000$ & JFPR \\
\hline 23 & E. M. & $07 / 08 / 2015$ & $10 / 09 / 2015$ & $5040086-03.2015 .404 .7000$ & JFPR \\
\hline 24 & F. M. & $28 / 08 / 2015$ & $21 / 09 / 2015$ & $5045962-36.2015 .404 .7000$ & JFPR \\
\hline 25 & W.S. & $04 / 08 / 2015$ & $29 / 09 / 2015$ & Pet 5779 & STF \\
\hline 26 & J.F. & $07 / 08 / 2015$ & $05 / 10 / 2015$ & $5040088-70.2015 .404 .7000$ & JFPR \\
\hline 27 & F. S. & $08 / 09 / 2015$ & $06 / 10 / 2015$ & Pet 5789 & STF \\
\hline 28 & J.F. & No date & $26 / 10 / 2015$ & $5051974-66.2015 .404 .7000$ & JFPR \\
\hline 29 & C. R. & $29 / 06 / 2015$ & $30 / 10 / 2015$ & Pet 5738 & STF \\
\hline 30 & A. C. & Sem data & $17 / 11 / 2015$ & $5055637-23.2015 .404 .7000$ & JFPR \\
\hline 31 & S. S. & Sem data & $17 / 11 / 2015$ & $5055731-68.2015 .404 .7000$ & JFPR \\
\hline 32 & R. P. & $29 / 09 / 2015$ & $09 / 12 / 2015$ & Pet 5849 & STF \\
\hline
\end{tabular}




\begin{tabular}{|c|c|c|c|c|c|}
\hline No. & Name $(*)$ & $\begin{array}{l}\text { Date of the } \\
\text { agreements' } \\
\text { conclusion }\end{array}$ & $\begin{array}{l}\text { Date of judi- } \\
\text { cial homolo- } \\
\text { gation }\end{array}$ & $\begin{array}{c}\text { No. of the proceeding in } \\
\text { which the agreement got } \\
\text { validated }\end{array}$ & $\begin{array}{l}\text { Court respon- } \\
\text { sible for ho- } \\
\text { mologation } \\
(* *)\end{array}$ \\
\hline 33 & R. J. & $29 / 09 / 2015$ & $09 / 12 / 2015$ & Pet 5849 & STF \\
\hline 34 & N.C. & $18 / 11 / 2015$ & $14 / 12 / 2015$ & Pet 5886 & STF \\
\hline 35 & L. S. & $03 / 12 / 2015$ & $17 / 12 / 2015$ & $5060002-23.2015 .404 .7000$ & JFPR \\
\hline 36 & A. R. & $07 / 10 / 2015$ & $05 / 02 / 2016$ & Pet 5879 & STF \\
\hline 37 & M. T. & $01 / 03 / 2016$ & $11 / 03 / 2016$ & $509065-72.2016 .404 .7000$ & JFPR \\
\hline 38 & D. G. & $11 / 02 / 2016$ & $14 / 03 / 2016$ & Pet 5952 & STF \\
\hline 39 & L. M. & $07 / 03 / 2016$ & $29 / 03 / 2016$ & Pet 5969 & STF \\
\hline 40 & E. F & $07 / 03 / 2016$ & $29 / 03 / 2016$ & Pet 5969 & STF \\
\hline 41 & L. M. & $07 / 03 / 2016$ & $29 / 03 / 2016$ & Pet 5969 & STF \\
\hline 42 & P.J. & No date & $29 / 03 / 2016$ & Pet 5969 & STF \\
\hline 43 & R. S. & No date & $05 / 04 / 2016$ & Pet 5998 & STF \\
\hline 44 & A. D. & No date & $05 / 04 / 2016$ & Pet 5998 & STF \\
\hline 45 & C. P. & No date & $05 / 04 / 2016$ & Pet 5998 & STF \\
\hline 46 & E. J. & No date & $05 / 04 / 2016$ & Pet 5998 & STF \\
\hline 47 & F. F. & No date & $05 / 04 / 2016$ & Pet 5998 & STF \\
\hline 48 & L. M. & No date & $05 / 04 / 2016$ & Pet 5998 & STF \\
\hline 49 & O. A. & No date & $05 / 04 / 2016$ & Pet 5998 & STF \\
\hline 50 & P. D. & No date & $05 / 04 / 2016$ & Pet 5998 & STF \\
\hline 51 & D. R. & $30 / 03 / 2016$ & $14 / 04 / 2016$ & Pet 6049 & STF \\
\hline 52 & J. M. & $04 / 05 / 2016$ & $24 / 05 / 2016$ & Pet 6138 & STF \\
\hline 53 & E. P. & $04 / 05 / 2016$ & $25 / 05 / 2016$ & Pet 6138 & STF \\
\hline 54 & D. M. & $04 / 05 / 2016$ & $25 / 05 / 2016$ & Pet 6138 & STF \\
\hline 55 & S. M. & $04 / 05 / 2016$ & $25 / 05 / 2016$ & Pet 6138 & STF \\
\hline 56 & C. C. & $27 / 04 / 2016$ & $06 / 06 / 2016$ & $5019866-47.2016 .404 .7000$ & JFPR \\
\hline 57 & V. B. & $10 / 06 / 2016$ & $12 / 07 / 2016$ & $5029481-61.2016 .404 .7000$ & JFPR \\
\hline 58 & M. B. & $16 / 06 / 2016$ & $12 / 07 / 2016$ & $5029481-61.2016 .404 .7000$ & JFPR \\
\hline 59 & L. F. & $16 / 06 / 2016$ & $12 / 07 / 2016$ & 5029481-61.2016.404.7000 & JFPR \\
\hline 60 & Z.S. & $12 / 07 / 2016$ & $06 / 10 / 2016$ & $5013405-59.2016 .4 .04 .7000$ & STF \\
\hline 61 & N. M. & $18 / 08 / 2016$ & $17 / 11 / 2016$ & Pet 6302 & STF \\
\hline 62 & L. M. & $18 / 08 / 2016$ & $17 / 11 / 2016$ & Pet 6302 & STF \\
\hline 63 & A. F. & $01 / 12 / 2016$ & $27 / 01 / 2017$ & Pet 6457 & STF \\
\hline 64 & C. R. & $01 / 12 / 2016$ & $27 / 01 / 2017$ & Pet 6470 & STF \\
\hline 65 & H. F. & $01 / 12 / 2016$ & $27 / 01 / 2017$ & Pet 6485 & STF \\
\hline 66 & M. R. & $01 / 12 / 2016$ & $28 / 01 / 2017$ & Pet 6501 & STF \\
\hline 67 & M. O. & $02 / 12 / 2016$ & $28 / 01 / 2017$ & Pet 6500 & STF \\
\hline 68 & I. S. & No date & $28 / 01 / 2017$ & Pet 6486 & STF \\
\hline
\end{tabular}




\begin{tabular}{|c|c|c|c|c|c|}
\hline No. & Name $(*)$ & $\begin{array}{l}\text { Date of the } \\
\text { agreements' } \\
\text { conclusion }\end{array}$ & $\begin{array}{l}\text { Date of judi- } \\
\text { cial homolo- } \\
\text { gation }\end{array}$ & $\begin{array}{c}\text { No. of the proceeding in } \\
\text { which the agreement got } \\
\text { validated }\end{array}$ & $\begin{array}{l}\text { Court respon- } \\
\text { sible for ho- } \\
\text { mologation } \\
\quad(* *)\end{array}$ \\
\hline 69 & L. S. & $02 / 12 / 2016$ & $28 / 01 / 2017$ & Pet 6496 & STF \\
\hline 70 & R. R. & $02 / 12 / 2016$ & $28 / 01 / 2017$ & Pet 6520 & STF \\
\hline 71 & O. J. & $02 / 12 / 2016$ & $28 / 01 / 2017$ & Pet 6509 & STF \\
\hline 72 & F.S. & $13 / 05 / 2016$ & $28 / 01 / 2017$ & Pet 6533 & STF \\
\hline 73 & M. S. & $01 / 12 / 2016$ & $28 / 01 / 2017$ & Pet 6502 & STF \\
\hline 74 & R. A. & $01 / 12 / 2016$ & $28 / 01 / 2017$ & Pet 6525 & STF \\
\hline 75 & B. J. & $01 / 12 / 2016$ & $28 / 01 / 2017$ & Pet 6464 & STF \\
\hline 76 & C. P & $01 / 12 / 2016$ & $28 / 01 / 2017$ & Pet 6465 & STF \\
\hline 77 & E. J. & $01 / 12 / 2016$ & $28 / 01 / 2017$ & Pet 6475 & STF \\
\hline 78 & J.S. & $26 / 01 / 2017$ & $08 / 02 / 2017$ & $5003359-74.2017 .404 .7000$ & JFPR \\
\hline 79 & E. C. & $26 / 01 / 2017$ & $08 / 02 / 2017$ & $5003362-29.2017 .404 .7000$ & JFPR \\
\hline 80 & E. K. & $01 / 12 / 2016$ & $12 / 02 / 2017$ & $560108-48.2016 .404 .7000$ & JFPR \\
\hline 81 & M. S. & $26 / 01 / 2017$ & $14 / 02 / 2017$ & $5003701-36.2017 .4 .04 .0000$ & TRF4 \\
\hline 82 & M. M. & $06 / 03 / 2017$ & $03 / 04 / 2017$ & Pet 6890 & STF \\
\hline 83 & J.F. & $06 / 03 / 2017$ & $03 / 04 / 2017$ & Pet 6890 & STF \\
\hline 84 & A. S. & $06 / 03 / 2017$ & $04 / 04 / 2017$ & Pet 6890 & STF \\
\hline 85 & J. B. & $03 / 05 / 2017$ & $11 / 05 / 2017$ & Pet 7.003 & STF \\
\hline 86 & W. B. & $03 / 05 / 2017$ & $11 / 05 / 2017$ & Pet 7.003 & STF \\
\hline 87 & R. S. & $03 / 05 / 2017$ & $11 / 05 / 2017$ & Pet 7.003 & STF \\
\hline 88 & A. N. & $28 / 04 / 2017$ & $22 / 05 / 2017$ & Pet 11962 & STJ \\
\hline 89 & E. D. & $28 / 04 / 2017$ & $22 / 05 / 2017$ & Pet 11962 & STJ \\
\hline 90 & P. A. & $10 / 03 / 2016$ & $01 / 08 / 2017$ & Pet 6199 & STF \\
\hline 91 & S. B. & $21 / 03 / 2017$ & $09 / 08 / 2017$ & Pet 7085 & STF \\
\hline 92 & R. B. & $21 / 03 / 2017$ & $09 / 08 / 2017$ & Pet 7085 & STF \\
\hline 93 & R. C. B. & $21 / 03 / 2017$ & $09 / 08 / 2017$ & Pet 7085 & STF \\
\hline 94 & S. C. & $21 / 03 / 2017$ & $09 / 08 / 2017$ & Pet 7085 & STF \\
\hline 95 & A. F. & $21 / 03 / 2017$ & $09 / 08 / 2017$ & Pet 7085 & STF \\
\hline 96 & A. A. & $08 / 08 / 2017$ & $05 / 09 / 2017$ & $5035490-05.2017 .404 .7000$ & JFPR \\
\hline 97 & L. F. & $21 / 08 / 2017$ & $05 / 09 / 2017$ & Pet 7210 & STF \\
\hline 98 & M. A. & $08 / 08 / 2017$ & $16 / 10 / 2017$ & $5037108-82.2017 .404 .7000$ & JFPR \\
\hline 99 & S. A. & $08 / 08 / 2017$ & $16 / 10 / 2017$ & $5038643-46.2017 .404 .7000$ & JFPR \\
\hline 100 & D. F. & $01 / 09 / 2017$ & $12 / 12 / 2017$ & Pet 7266 & STF \\
\hline 101 & J. Q. & $01 / 09 / 2017$ & $12 / 12 / 2017$ & Pet 7266 & STF \\
\hline 102 & L. J. & $01 / 12 / 2016$ & $28 / 12 / 2017$ & Pet 6498 & STF \\
\hline 103 & N. J. & $04 / 05 / 2018$ & $01 / 06 / 2018$ & $5019872-34.2018 .4 .04 .0000$ & TRF4 \\
\hline 104 & H. O. & $04 / 07 / 2018$ & $23 / 07 / 2018$ & $5026581-85.2018 .4 .04 .0000$ & TRF4 \\
\hline
\end{tabular}




\begin{tabular}{|c|c|c|c|c|c|}
\hline No. & Name $\left(^{*}\right)$ & $\begin{array}{c}\text { Date of the } \\
\text { agreements' } \\
\text { conclusion }\end{array}$ & $\begin{array}{c}\text { Date of judi- } \\
\text { cial homolo- } \\
\text { gation }\end{array}$ & $\begin{array}{c}\text { No. of the proceeding in } \\
\text { which the agreement got } \\
\text { validated }\end{array}$ & $\begin{array}{c}\text { Court respon- } \\
\text { sible for ho- } \\
\text { mologation } \\
(* *)\end{array}$ \\
\hline 105 & Hu. O. & $08 / 08 / 2018$ & $17 / 08 / 2018$ & $5033900-56.2018 .4 .04 .7000$ & JFPR \\
\hline 106 & R. O. & $01 / 12 / 2016$ & $28 / 09 / 2018$ & $5037101-56.2018 .4 .04 .7000$ & JFPR \\
\hline
\end{tabular}

The agreements were gathered through the analysis of the public records of criminal proceedings related to different anti-corruption investigations occurred in Brazil between the years of 2014 and 2018. Many agreements have been also published in the Brazilian press.

(*) Although all agreements can be found in public records, the names of the cooperating defendants were abbreviated to preserve the identity of the individuals as much as possible.

${ }^{(* *)}$ Federal Supreme Court - STF; Superior Court of Justice - STJ; Federal Regional Tribunal of the $4^{\text {th }}$ Region - TRF4; Federal Court of Paraná - JFPR. 


\section{References}

Acconcia A and others, 'Accomplice Witnesses and Organized Crime: Theory and Evidence from Italy' (2014) 116 Scandinavian Journal of Economics 1116

Agator M, 'Iraq: Overview of Corruption and Anti-Corruption' (2013) 374 U4 Expert Answer

Alonso G de O, 'A Colaboração Premiada e o Princípio "Nulla Poena Sine Judicio”" (2018) XIV Revista Magister de Direito Penal e Processual Penal 71

Alschuler AW, 'Plea Bargaining and Its History' (1979) 13 Law \& Society Review 211

Altenhain K, Dietmeier F and May M, Die Praxis Der Absprachen in Strafverfabren (Nomos 2013)

_- Die Praxis Der Absprachen in Strafverfahren (Nomos 2013)

Altenhain K and Haimerl M, 'Die Gesetzliche Regelung Der Verständigung Im Strafverfahren - Eine Verweigerte Reform' (2010) JZ 327

Alves JC, 'Justiça Consensual e "Plea Bargaining"' in Rodrigo Leite Ferreira et al Cabral (ed), Acordo de não persecução penal-Resolução 181/2017 do CNMP com as alterações feitas pela Res. 183/2018 (Juspodivm 2019)

Anderson PL, Bolema TR and Geckil IK, 'Damages in Antitrust Cases' (2007) 2 Antitrust Damages - Anderson Economic Group

Anselmo MA, 'Colaboração Premiada Como Novo Paradigma Do Processo Penal Brasileiro', Estudos em homenagem ao professor Sérgio Moro (Instituto Memória Editora 2017)

Aras V, 'Acordos Penais No Brasil: Uma Análise à Luz Do Direito Comparado' in Rodrigo Leite Ferreira et al Cabral (ed), Acordo de não persecução penal-Resolução 181/2017 do CNMP com as alterações feitas pela Res. 183/2018 (Juspodivm 2019)

Aubert C, Rey P and Kovacic WE, 'The Impact of Leniency and Whistle-Blowing Programs on Cartels' (2006) 24 International Journal of Industrial Organization 1241

Badaró GH, 'A Colaboração Premiada: Meio de Prova, Meio de Obtenção de Prova Ou Um Novo Modelo de Justiça Penal Não Epistêmica?’ in Maria Thereza de Assis Moura and Pierpaolo Cruz Bottini (eds), Colaboração premiada (Revista dos Tribunais 2017)

Bannenberg B, Korruption in Deutschland Und Ibre Strafrechtliche Kontrolle (Hermann Luchterhand 2002)

Bar-Gill O and Gazal Ayal O, 'Plea Bargains Only for the Guilty' (2006) XLIX Journal of Law and Economics 353

Barbosa Bittar W, Delação Premiada: Direito Estrangeiro, Doutrina e Jurisprudência (Lumen Juris 2011) 
Barbot L, 'Money Laundering: An International Challenge' (1995) 3 Tul. J. Int'l \& Comp. L.

Barkow RE, 'Institutional Design and the Policing of Prosecutors: Lessons from Administrative Law' (2009) 61 Stanford Law Review 869

Barroso LR, 'Thirty Years of the Brazilian Constitution: The Republic That Is Yet to Be' (2018) SSRN Electronic Journal 1

Beaton-Wells C, 'Leniency Policies: Revolution or Religion?' in Caron BeatonWells and Christopher Tran (eds), Anti-cartel enforcement in a contemporary age: leniency policies (Hart Publishing 2015)

Beaton-Wells CY, 'Immunity for Cartel Conduct: Revolution or Religion? An Australian Case Study' (2014) 2 Journal of Antitrust Enforcement 126

Berman DA, 'Foreword: Beyond Blakely and Booker: Pondering Modern Sentencing Process' (2005) 95 The Journal of Criminal Law and Criminology 653

Bersch K, Praça S and Taylor MM, 'State Capacity, Bureaucratic Politicization, and Corruption in the Brazilian State' (2017) 30 Governance 105

Bibas S, 'Judicial Fact-Finding and Sentence Enhancements in a World of Guilty Pleas' (2001) 110 The Yale Law Journal 1097

_- ' 'Harmonizing Substantive-Criminal-Law Values and Criminal Procedure: The Case of Alford and Nolo Contendere Pleas' (2003) 88 Cornell Law Review 1361

Bigoni M and others, 'Fines, Leniency, and Rewards in Antitrust' (2012) 43 RAND Journal of Economics 368

___, 'Trust, Leniency, and Deterrence' (2015) 31 Journal of Law, Economics, and Organization 663

Borrell J-R, Jiménez JL and Garcia C, 'Evaluating Antitrust Leniency Programs' (2014) 10 Journal of Competition Law and Economics 107

Bos I and Wandschneider F, 'A Note on Cartel Ringleaders and the Corporate Leniency Programme' (2013) 20 Applied Economics Letters 1100

Bottini PC, 'A Homologação e a Sentença Na Colaboração Premiada Na Ótica Do STF' in Maria Thereza de Assis Moura and Pierpaolo Cruz Bottini (eds), Colaboração premiada (Revista dos Tribunais 2017)

Bottino T, 'Colaboração Premiada E Incentivos À Cooperação No Processo Penal : Uma Análise Crítica Dos Acordos Firmados Na “ Operação Lava Jato ”' (2016) 122 Revista Brasileira de Ciências Criminais 359

Breucker M and Engberding ROM, Die Kronzeugenregelung - Erfahrungen, Anwendungsfalle, Entwicklungen (Richard Boorberg Verlag 1999)

Brodowski D, 'Die Verfassungsrechtliche Legitimation Des US-Amerikanischen „plea Bargaining“ - Lehren Für Verfahrensabsprachen Nach $\$ 257$ c StPO?" (2013) 124 Zeitschrift für die gesamte Strafrechtswissenschaft 733

Brüning J, 'Die Einstellung Nach $₫ 153$ a StPO - Moderner Ablasshandel Oder Rettungsanker Der Justiz?’ (2015) 12 Strafrecht - Jugendstrafrecht - Kriminalprävention in Wissenschaft und Praxis 125 
Buccirossi P and Spagnolo G, 'Leniency Policies and Illegal Transactions' (2006) 90 Journal of Public Economics 1281

Buell SW, 'Is the White Collar Offender Privileged?' (2014) 63 Duke Law Journal 823

Burnier P and Fernandes VO, "The "Car Wash Operation" in Brazil and Its Challenges for Antitrust Bid Rigging Enforcement' in Paulo Burner da Silveira and William Evan Kovacic (eds), Global Competition Enforcement: New Players, New Challenges (Kluwer 2019)

Buzari A, Kronzeugenregelungen in Straf-Und Kartellrecht Unter Besonderer Berücksichtigung Des $\ 46$ b StGB (Strafrecht in Forschung Und Praxis) (Verlag Dr Kovac 2015)

Cairns JW, 'Watson, Walton, and the History of Legal Transplants' (2013) 41 The Georgia Journal of International and Comparative Law 637

Callegari A and Linhares R, Colaboração premiada: lições práticas e téoricas de acordo com a jurisprudência do Supremo Tribunal Federal (Livraria do Advogado 2019)

Calliari M and Guimarães DA, 'Brazilian Cartel Enforcement: From Revolution to The Challenges of Consolidation' (2011) 25 Antitrust Magazine 67

Canotilho JJG and Brandão N, 'Colaboração Premiada e Auxílio Judiciário Em Matéria Penal: A Ordem Pública Como Obstáculo à Cooperação Com a Operação Lava Jato’ (2016) 146 Revista de Legislação e Jurisprudência 16

Carduck VJ, 'Quo Vadis, German Criminal Justice System? The Future of Plea Bargaining in Germany' The Future of Plea Bargaining in Germany' (2013) Warwick School of Law Research Paper 2013-17, $1<$ https://papers.ssrn.com/sol3/pap ers.cfm?abstract_id=2316828 $>$ accessed 20 September 2019

Caruso A, 'Leniency Programmes and Protection of Confidentiality: The Experience of the European Commission' (2010) 1 Journal of European Competition Law \& Practice 453

Carvalho NO, A Delação Premiada No Brasil (Lumen Juris 2009)

Carvalho S de, 'Colaboração Premiada e Aplicação Da Pena: Garantias e Incertezas Dos Acordos Realizados Na Operação Lava Jato' in Américo Bedê Júnior and Gabriel Silveira de Queirós Campos (eds), Sentenca criminal e aplicação da pena: ensaios sobre discricionariedade, individualização e proporcionalidade (Juspodivm 2017)

Castro A and Ansari S, 'Contextual "Readiness" for Institutional Work. A Study of the Fight Against Corruption in Brazil' (2017) 26 Journal of Management Inquiry 351

Castro MF de, 'Abrenuntio Satanae! A Colaboração Premiada Na Lei $\mathrm{N}^{\circ}$ 12.850/2013: Um Novo Paradigma de Sistema Penal Contratual?' (2018) Revista de Estudos Criminais 171

Cavali MC, 'Duas Faces Da Colaboração Premiada: Visões "Conservadora" e "Arrojada” Do Instituto Na Lei 12.850/2013' in Maria Thereza de Assis Moura and Pierpaolo Cruz Bottini (eds), Colaboração premiada (Revista dos Tribunais 2017) 
Cavazotte F, Cohen M and Brunelli M, 'Business Ethics in Brazil: Analyzing Discourse and Practice of the Brazilian Contractors Involved in Operation Lava Jato' in Christopher Stehr, Nina Dziatzko and Franziska Struve (eds), Corporate Social Responsibility in Brazil (Springer, Cham 2019)

Centonze F, 'Public-Private Partnerships and Agency Problems: The Use of Incentives in Strategies to Combat Corruption' in Springer International (ed), Preventing Corporate Corruption (Springer International Publishing 2014)

Cheesman SJ, 'Comparative Perspectives on Plea Bargaining in Germany and the U.S.A.' (2014) <https://publishup.uni-potsdam.de/opus4-ubp/frontdoor/deliver/i ndex/docId/7457/file/S113-151_aiup02.pdf> accessed 18 July 2019

Choi JP and Gerlach H, 'Global Cartels, Leniency Programs and International Antitrust Cooperation' (2012) 30 International Journal of Industrial Organization 528

Christoph S, Der Kronzeuge Im Strafgesetzbuch: Die Ermittlungshilfe Gemäß $\$ 46 b$ StGB Aus Dogmatischer Und Empirischer Perspektive (Nomos 2019)

Colombo G, 'Investigating and Prosecuting Large-Scale Corruption: The Italian Experience' (2006) 4 Journal of International Criminal Justice 510

Cooter R and Freedman BJ, 'The Fiduciary Relationship: Its Economic Character and Legal Consequences' (1991) 66 New York University Law Review 1045

Crijns JH, Dubelaar MJ and Pitcher KM, Collaboration with Justice in the Netherlands, Germany, Italy and Canada (Universiteit Leiden 2017)

Dallagnol D and Pozzobon R, 'Ações e Reações No Esforço Contra a Corrupção No Brasil' in Maria Cristina Pinotti (ed), Corrupção: Lava Jato e Mãos Limpas (Portfolio-Penguin 2019)

Damaska M, 'Structures of Authority and Comparative Criminal Procedure' (1975) 84 The Yale Law Journal 480

Damaska M, 'Negotiated Justice in International Criminal Courts' (2004) 2 Journal of International Criminal Justice 1018

Damaška M, 'The Uncertain Fate of Evidentiary Transplants: Anglo-American and Continental Experiments' (1997) 45 American Journal of Comparative Law 839

__ , "Symposium on Guilty Plea Part I: The Theoretical Background Negotiated Justice in International Criminal Courts' (2004) 2 Journal of International Criminal Justice 1018

Davies S and De O, 'Ringleaders in Larger Number Asymmetric Cartels' (2013) 123 Economic Journal 524

Davis E. K, Between Impunity and Imperialism: The Regulation of Transnational Bribery (Oxford 2019)

De Almeida MA and Zagaris B, 'Political Capture in the Petrobras Corruption Scandal: The Sad Tale of an Oil Giant' (2015) 39 The Fletcher Forum of World Affairs 87

Deal D, ‘Aus Der Praxis. Der Strafprozessuale Vergleich’ (1982) Strafverteidiger 545 
Dell'Osso V, 'Empirical Features of International Bribery Practice: Evidence from Foreign Corrupt Practices Act Enforcement Actions' in Stefano Manacorda, Francesco Centonze and Gabrio Forti (eds), Preventing corporate corruption: the anti-bribery compliance model (Springer International Publishing 2014)

DeMarzo PM and Duffie D, 'Corporate Incentives for Hedging and Hedge Accounting' (1995) 8 The Review of Financial Studies 743

Didier Jr. F and Bomfim D, 'Colaboração Premiada (Lei n.12850/13): natureza jurídica e controle da validade por demanda autônoma - um diálogo com o Direito Processual Civil' (2016) 7 Civil Procedure Review 135

Dino N, 'A Colaboração Premiada Na Improbidade Administrativa: Possibilidade e Repercussão Probatória' in Daniel de Resende Salgado and Ronaldo Pinheiro de Queiroz (eds), A prova no enfrentamento à macrocriminalidade (Juspodivm 2016)

Dixon M and Kate E, 'Too Much of a Good Thing? Is Heavy Reliance on Leniency Eroding Cartel Enforcement in the United States?' (2014) 12 CPI Antitrust Chronicle 2

Dorfman A, 'Property and Collective Undertaking: The Principle of Numerus Clausus' (2011) 61 University of Toronto Law Journal 467

Dubber MD, 'American Plea Bargains, German Lay Judges, and the Crisis of Criminal Procedure' (1997) 49 Stanford Law Review 547

Dubber MD and Hörnle T, Criminal Law: A Comparative Approach (Oxford University Press 2014)

Ellis CJ and Wilson WW, 'What Doesn't Kill Us Makes Us Stronger: An Analysis of Corporate Leniency Policy' 1

Engelhart M, 'Development and Status of Economic Criminal Law in Germany' (2014) 15 German Law Journal 693

Estellita H, 'A Delação Premiada Para a Identificação Dos Demais Coautores Ou Partícipes: Algumas Reflexões à Luz Do Devido Processo Legal' (2009) 17 Boletim IBCCRIM 2

Ewald W, 'Comparative Jurisprudence (II): The Logic of Legal Transplants' (1995) 43 The American Journal of Comparative Law 489

Fauvarque-Cosson B and others, European Contract Law: Materials for a Common Frame of Reference: Terminology, Guiding Principles, Model Rules (Sellier European Law Publishers 2009)

Federal MP, '10 Medidas Contra Corrupção' (Apoiadores, 2016) <http://www.dezme didas.mpf.mp.br/campanha/apoiadores $>$ accessed 17 July 2019

Feess E and Walzl M, 'Quid-pro-Quo or Winner-Takes-It-All? An Analysis of Corporate Leniency Programs and Lessons to Learn for US and EU Policies' (2005) METEOR Research Memorandum 059, Maastricht University School of Business and Economics <https://cris.maastrichtuniversity.nl/portal/files/1144059/gu id-89205720-706f-4ddb-89a8-3aa1e71508f8-ASSET1.0> accessed 18 June 2019

Fernandes AS, 'O Equilíbrio Entre a Eficiência E O Garantismo E O Crime Organizado' in Denise Provasi Vaz and others (eds), Eficiência e garantismo no processo penal, vol 70 (LiberArs 2008) 
Fernandes MCP, Contratos: Eficácia e Relatividade Nas Coligações Contratuais (Saraiva 2014)

Findlay M, Governing through Globalised Crime: Futures for International Criminal Justice (Routledge 2013)

First H, 'Branch Office of the Prosecutor: The New Role of the Corporation in Business Crime Prosecutions' (2010) 89 North Carolina Law Review 23

Fischer D, 'Em Busca Da Aplicação Correta e Justa Das Penas Perdidas: O Caos Decorrentes de Um Sistema Anacrônico e Repetitivo de "Precedentes-Ementas" in Américo Bedê Júnior and Gabriel Silveira de Queirós Campos (eds), Sentença criminal e aplicação da pena: ensaios sobre discricionariedade, individualização e proporcionalidade (Juspodivm 2017)

Fissé B, 'Reconditioning Corporate Leniency: The Possibility of Making Compliance Programmes a Condition of Immunity' in Caron Beaton-Wells and Christopher Tran (eds), Anti-Cartel Enforcement in a Contemporary Age: Leniency Religion (Hart Publishing 2015)

Fleischer D, 'Political Corruption in Brazil: The Delicate Connection with Campaign Finance' (1996) 25 Crime, Law and Social Change 297

Fogelklou A, “The Regional Ombudsman as a Western (Swedish) Legal Transplant: ", : Experiences from the Legislative Process in St. Petersburg' (2003) 13, Transnational Law and Contemporary Problems 537

Fonseca CBG da, Colaboração Premiada (Del Rey 2017)

Forrester IS and Berghe P, 'Leniency: The Poisoned Chalice or the Pot at the End of the Rainbow?' in Caron Beaton-Wells and Christopher Tran (eds), Anti-Cartel Enforcement in a Contemporary Age: Leniency Policies (Hart Publishing 2015)

Frahm LN, Die Allgemeine Kronzeugenregelung: Dogmatische Probleme Und Rechtspraxis Des $\$ 46 b$ StGB (Duncker \& Humblot 2014)

Friederiszick HW and Maier-Rigaud FP, 'Triggering Inspections Ex Officio: Moving beyond a Passive EU Cartel Policy' (2008) 4 Journal of Competition Law and Economics 89

Fudenberg D and Maskin E, 'The Folk Theorem in Repeated Games with Discounting or with Incomplete Information' (1986) 54 Econometrica 533

Fundenberg D and Maskin E, 'American Economic Association Evolution and Cooperation in Noisy Repeated Games' (1990) 80 The American Economic Review 274

Fyfe $\mathrm{N}$ and Sheptycki J, 'International Trends in the Facilitation of Witness Co-Operation in Organized Crime Cases' (2006) 3 European Journal of Criminology 319

Gambaro A, 'Abuse of Rights in Civil Law Tradition' (1995) 3 European Review of Private Law 561

Gambetta D and Reuter P, 'Conspiracy among the Many: The Mafia in Legitimate Industries' in Gianluca Fiorentini and Sam Peltzman (eds), The Economics of Organised Crime (Cambridge University Press 1995)

Garoupa N and Ogus A, 'A Strategic Interpretation of Legal Transplants' (2006) 35 Journal of Legal Studies 339 
Geller PE, 'Legal Transplants in International Copyright: Some Problemas of Method' (1994) 13 UCLA Pacific Basin Law Journal 199

Gifford DG, 'Meaningful Reform of a Plea Bargaining: The Control of Prosecutorial Discretion' (1983) University of Illinois Law Review 37

Goddin G, 'The Pfleiderer Judgment on Transparency: The National Sequel of the Access to Document Saga' (2012) 3 Journal of European Competition Law \& Practice 40

Gomes LF and Cervini R, Crime Organizado - Enfoques Criminológicos, Jurídicos (Lei 9.034/95) e Político-Criminal (Revista dos Tribunais 1997)

Goodrich HF, 'Privity of Contract and Tort Liability' (1922) 21 Michigan Law Review 200

Greco L, '„Fortgeleiteter Schmerz“ - Überlegungen Zum Verhältnis von Prozessabsprache, Wahrheitsermittlung Und Prozessstruktur' (2016) 1 Goltdammer's Archiv für Strafrecht 1

Greco L, 'Annäherungen an Eine Theorie Der Korruption' (2016) 163 Goltdammer's Archiv für Strafrecht 249

Greco L and Caracas C, 'Internal Investigations Und Selbstbelastungsfreiheit' (2015) 7 NStZ 7

Greco L and Leite A, 'Die „Rezeption“ Der Tat- Und Organisationsherrschaft Im Brasilianischen Wirtschaftsstrafrecht' (2014) 6 ZIS - Zeitschrift für Internationale Strafrechtdogmatik 285

Greco L, Strafprozesstheorie Und Materielle Rechtskraft (Duncker \& Humblot 2015)

__- 'Reflexões Provisórias Sobre o Crime de Enriquecimento Ilícito' in Alaor Leite and Adriano Teixeira (eds), Crime e politica: corrupção, financiamento irregular de partidos políticos, caixa dois eleitoral e enriquecimento ilícito. (FGV Editora 2017)

Greenblum BM, 'What Happens to a Prosecution Deferred? Judicial Oversight of Corporate Deferred Prosecution Agreements' (2005) 105 Columbia Law Review 1863

Hagopian F, 'Delegative Democracy Revisited Brazil' s Accountability Paradox' (2016) 27 Journal of Democracy 119

Halberstam M, 'Towards Neutral Principles in the Administration of Criminal Justice: A Critique of Supreme Court Decisions Sanctioning the Plea Bargaining Process' (1982) 73 Journal of Criminal Law and Criminology 1

Hammond SD, 'Detecting and Deterring Cartel Activity through an Effective Leniency Program', International Workshop on Cartels (DOJ 2000)

__ , 'Cornerstones of an Effective Cartel Leniency Programme' (2008) 4 Competition Law International 4

Harding C, Beaton-Wells C and Edwards J, 'Leniency and Criminal Sanctions in Anti-Cartel Enforcement: Happily Married or Uneasy Bedfellows?' in Caron Beaton-Wells and Christopher Tran (eds), Anti-cartel enforcement in a contemporary age: leniency policies (Hart Publishing 2015) 
Harrington JE and Chang MH, 'When Can We Expect a Corporate Leniency Program to Result in Fewer Cartels?' (2015) 58 Journal of Law and Economics 417

Harrington Jr. JE, 'Optimal Corporate Leniency Programs' (2008) 56 The Journal of Industrial Economics 215

Hart O, Shleifer A and Vishny RW, 'The Proper Scope of Government: Theory and an Application to Prisons' (1997) The Quarterly Journal of Economics 1127

Hassemer W, 'Kronzeugenregelung Bei Terroristischen Straftaten Thesen Zu Art. 3 Des Entwurfs Eines Gesetzes Zur Bekämpfung Des Terrorismus’ (1986) 550 StrafVert

___, 'Pacta Sunt Servanda - Auch Im Strafprozess?' (1989) 11 Juristische Schulung 890

___ 'Kennzeichen Und Krisen Des Modernen Strafrechts' (1992) 25 Zeitschrift für Rechtspolitik 378

__ , 'Konsens Im Strafprozeß' in Regina Michalke and others (eds), Festschrift für Rainer Hamm zum 65. Geburtstag am 24. Februar 2008 (De Gruyter 2009)

__ - 'Human Dignity in the Criminal Process: The Example of Truth-Finding' (2011) 44 Israel Law Review 185

Hefendehl R, Kollektive Rechtsgüter Im Strafrecht (Carl Heymanns Verlag KG 2002)

_- , 'Das Rechtsgut Als Materialer Angelpunkt Einer Strafnorm', Die Rechtsgutstheorie: Legitimationsbasis des Strafrechts oder dogmatisches Glasperlenspiel? (Nomos 2003)

__ , 'Enron, WorldCom, and the Consequences: Business Criminal Law Between Doctrinal Requirements and the Hopes of Crime Policy' (2004) 8 Buffalo Criminal Law Review 51

__, 'Enron, Worldcom Und Die Folgen: Das Wirtschaftsstrafrecht Zwischen Erfordernissen Kriminalpolitischen Erwartungen Und Dogmatischen Erfordernissen' (2004) 59 JuristenZeitung 18

___, 'Außerstrafrechtliche Und Strafrechtliche Instrumentarien Zur Eindämmung Der Wirtschaftskriminalität' (2007) 119 Zeitschrift für die gesamte Strafrechtswissenschaft 816

__, 'Addressing White Collar Crime on a Domestic Level' (2010) 8 Journal of International Criminal Justice 769

__ , 'Corporate Governance Und Business Ethics: Scheinberuhigung Oder Alternativen Bei Der Bekämpfung Der Wirtschaftskriminalität?' (2016) 61 JuristenZeitung 119

Heger M, 'Adversarial and Inquisitorial Elements in the Criminal Justice Systems of European Countries as a Challenge for the Europeanization of the Criminal Procedure', in: BSU Law Faculty (ed.), Criminal proceeding based on the rule of law as the means to ensure human rights (Publishing Centre of BSU Minsk 2017)

Heger M and Pest R, 'Verständigungen Im Strafverfahren Nach Dem Urteil Des Bundesverfassungsgerichts' (2014) 126 Zeitschrift für die gesamte Strafrechtswissenschaft 446 
Heger M and Kutter-Lang H, Strafprozessrecht (Verlag W. Kohlhammer 2013)

Henderson J V., 'Externalities in a Spatial Context. The Case of Air Pollution' (1977) 7 Journal of Public Economics 89

Herre J and Rasch A, The Deterrence Effect of Excluding Ringleaders from Leniency Programs (University of Cologne 2009)

Herrman J, 'Bargaining Justice - A Bargain for German Criminal Justice?' (1991) 53 University of Pittsburgh Law Review 755

Hesch M, 'The Effects of Ringleader Discrimination on Cartel Stability and Deterrence - Experimental Insights' (2012) 3 Journal of Advanced Research in Law and Economics 9

Hessick III FA and Saujani RM, 'Plea Bargaining and Convicting the Innocent: The Role of the Prosecutor, the Defense Counsel, and the Judge' (2002) 16 Brigham Young University Journal of Public Law 189

Hornle T, 'Unterschiede Zwischen Strafverfahrensordnungen Und Ihre Kulturellen Hintergründe' (2006) 117 Zeitschrift für die Gesamte Strafrechtswissenschaft 801

Hörnle T, 'Die Vermögensstrafe: Ein Beispiel Für Die Unorganisierten Konsequenzen von Gesetz- Geberischen Anstrengungen Zur Bekämpfung Organisierter Kriminalität' (1996) 108 Zeitschrift für die gesamte Strafrechtswissenschaft 333

__ , “Justice and Fairness”: Ein Modell Auch Für Das Strafverfahren?' (2004) 35 Rechtstheorie 175

Hovenkamp H, The Antitrust Enterprise (Harvard University Press 2015)

Hoyer A, 'Die Figur Des Kronzeugen: Dogmatische, Verfahrensrechtliche Und Kriminalpolitische Aspekte' (1994) 49 JuristenZeitung 233

Hughes G, 'Agreements for Cooperation in Criminal Cases' (1992) 45 Vanderbilt Law Review 1

ICN, 'Anti-Cartel Enforcement Manual' (2014)

Issacharoff S and Karlan PS, 'The Hydraulics of Campaign Finance Reform' (2009) 77 Texas Law Review 1705

Jaeger M, 'Der Kronzeuge Unter Besonderer Berücksichtigung von $₫ 31$ BtMG' (Peter Lang 1986)

Jahn M and Müller M, 'Das Gesetz Zur Regelung Der Verständigung Im Strafverfahren - Legitimation Und Reglementierung Der Absprachenpraxis' (2009) 62 Neue juristische Wochenschrift 1

Janot R, 'The Lessons of Car Wash' (2018) Americas Quarterly <https:/www.ameri casquarterly.org/content/lessons-car-wash> accessed 23 July 2019

Jaspers JD, 'Managing Cartels: How Cartel Participants Create Stability in the Absence of Law' (2017) 23 European Journal on Criminal Policy and Research 319

Jeßberger F, Kooperation Und Strafzumessung: Der Kronzeuge Im Deutschen Und Amerikanischen Strafrecht (Duncker \& Humblot GmbH 1999)

—_, 'Nulla Poena Quamvis in Culpa: Ammerkungen Zur Kronzeugenregelung in $\$ 46$ StGB' in Christian Fahl and others (eds), Festschrift für Werner Beulke (C F Müller 2015) 
Jessel-Holst C, Kulms R and Trunk A, Private Law in Eastern Europe Autonomous Developments or Legal Transplants? (Mohr Siebeck 2010)

Jul M and Pdf H, 'PART I : THE THEORETICAL BACKGROUND Negotiated Justice in International Criminal Courts' (2015) 1 Journal of International Criminal Justice 1018

Jung H, 'Der Kronzeuge - Garant Der Wahrheitsfindung Oder Instrument Der Überführung?' (1986) 19 Zeitschrift für Rechtspolitik 38

Justice D of, 'Odebrecht and Braskem Plead Guilty and Agree to Pay at Least \$3.5 Billion in Global Penalties to Resolve Largest Foreign Bribery Case in History' (Department of Justice, 21 December 2016) < https://www.justice.gov/opa/pr/odeb recht-and-braskem-plead-guilty-and-agree-pay-least-35-billion-global-penalties-res olve> accessed 1 October 2019

Kaspar J, 'Stellungnahme Zum „Entwurf Eines...Strafrechtsänderungsgesetzes Beschränkung Der Möglichkeit Zur Strafmilderung Bei Aufklärungs- Und Präventionshilfe“ (BT-Drucks. 17/9695)’ (2012) 86135 Augsburg 1

Katz J, 'Legality and Equality: Plea Bargaining in the Prosecution of White-Collar and Common Crimes' (1979) 13 Law \& Society Review 431

Kempf E, 'Gesetzliche Regelung von Absprachen Im Strafverfahren? Oder: Soll Informelles Formalisiert Werden?' (2009) StV 269

Klijn EH and Teisman GR, 'Institutional and Strategic Barriers to Public-Private Partnership: An Analysis of Dutch Cases' (2003) 23 Public Money and Management 137

Kloub J, 'Leniency as the Most Effective Tool in Combating Cartels' (Latin American Competition Forum 2009)

Kneba N, Die Kronzeugenregelung Des $\$ 46$ b StGB (Duncker 2011)

Knizhnik S, 'Failed Snitches and Sentencing Stitches: Substantial Assistance and the Cooperator's Dilemma' (2015) 90 New York University Law Review 1722

Kobayashi BH, 'Antitrust, Agency, and Amnesty: An Economic Analysis of the Criminal Enforcement of the Antitrust Laws against Corporations' (2001) 69 The George Washington Law Review 715

König S and Fassung G, 'Kronzeuge - Abschaffen Oder Regulieren?' (2012) Strafverteidiger 113

Körner HH, 'Der Aufklärungsgehilfe Nach $₫ 31$ BtMG' (1984) Strafverteidiger 217

Kovacic WE, 'A Case for Capping the Dosage: Leniency and Competition Authority Governance' in Caron Beaton-Wells and Christopher Tran (eds), Anti-cartel enforcement in a contemporary age: leniency policies (Hart Publishing 2015)

Kulms R, 'Optimistic Normativism after Two Decades of Legal Transplants and Autonomous Developments', Private Law in Eastern Europe: Autonomous Developments or Legal Transplants? (Mohr Siebeck 2010)

Kurtenbach S and Nolte D, 'Latin America's Fight against Corruption: The End of Impunity' (2017) 3 GIGA Focus Latin America

Labs K, Die Strafrechtliche Kronzeugenregelung - Legitimation Einer Rechtlichen Grauzone? (Tectum Wissenschaftsverlag 2016) 
Lambsdorff JG, 'Causes and Consequences of Corruption: What Do We Know from a Cross-Section of Countries?' in Susan Rose-Ackerman (ed), International Handbook on the Economics of Corruption (Edward Elgar 2006)

Lampe K von, 'Bekämpfung Der Organisierten Kriminalität' (2010) 3 SIAK-Journal - Zeitschrift für Polizeiwissenschaft und polizeiliche Praxis 50

Langbein JH, 'Land without Plea Bargaining: How the Germans Do It' (1979) 78 Michigan Law Review 204

Langer M, 'From Legal Transplants to Legal Translations: The Globalization of Plea Bargaining and the Americanization Thesis in Criminal Procedure' (2004) 45 Harvard International Law Journal 1

Legrand P, 'The Impossibility of "Legal Transplants"' (1997) 4 Maastricht Journal of European and Comparative Law 111

Leite A and Teixeira A, Crime e Política (FGV Editora 2017)

Lejeune S, 'Brauchen Wir Eine Kronzeugenregelung Zur Verfolgung von Korruptionsfällen?' in Transparency International (ed), Korruption in Deutschland: Strafverfolgung der Korruption Möglichkeinten und Grenzen (2004)

Lenza P, Reis ACA and Gonçalves VER, Direito Processual Penal Esquematizado, vol 2014 (Saraiva 2012)

Leslie CR, 'Trust, Distrust and Antitrust' (2004) 82 Texas Law Review 515

__ , 'Antitrust Amnesty, Game Theory, and Cartel Stability' (2006) 31 The Journal of Corporation Law 453

Levenstein M and Suslow VY, 'Contemporary International Cartels and Developing Countries: Economic Effects and Implications for Competition Policy' (2004) 71 Antitrust Law Journal 801

Lewin P, 'Pollution Externalities: Social Cost and Strict Liability' (1982) 2 Cato Journ1al 205

Li Q and others, 'Buy Now and Price Later: Supply Contracts with Time-Consistent Mean-Variance Financial Hedging' (2018) 268 European Journal of Operational Research 582

Lima RB de, Legislação Criminal Especial Comentada (Juspodivm 2016)

Lima MB, 'A Colaboração Premiada Como Instrumento Constitucionalmente Legítimo de Auxílio à Atividade Estatal de Persecução Criminal' in Bruno Calabrich, Douglas Fischer and Eduardo Pelella (eds), Garantismo penal integral: questões penais e processuais, criminalidade moderna e a aplicação do modelo garantista no Brasil (Juspodivm 2013)

Lindemann M, 'Staatlich Organisierte Anonymität Als Ermittlungsmethode Bei Korruptions- Und Wirtschaftsdelikten' (2006) 39 Zeitschrift für Rechtspolitik 127

Lindner W, 'Korruptionsbekämpfung Im Anonymen Dialog. Ein Webbasiertes Hinweisgebersystem Im Einsatz Bei Der Zentralstelle Korruptionsbekämpfung Des LKA Niedersachsens' in Transparency International (ed), Korruption in Deutschland: Strafverfolgung der Korruption Möglichkeiten und Grenzen (allprintmedia 2004) 
Linhares AAM and Fidelis AL, 'Nearly 16 Years of the Leniency Program in Brazil : Breakthroughs and Challenges in Cartel Prosecution' (2016) 3 Antitrust Chronicle 39

Luz RD and Spagnolo G, 'Leniency, Collusion, Corruption, and Whistleblowing' (2017) 13 Journal of Competition Law \& Economics 729

Maffei S, "Negotiations “on Evidence” and Negotiations "on Sentence”: Adversarial Experiments in Italian Criminal Procedure' (2004) 2 Journal of International Criminal Justice 1050

Malek K, 'Die Neue Kronzeugenregelung Und Ihre Auswirkungen Auf Die Praxis Der Strafverteidigung' (2010) StV 200

—_, 'Abschied von Der Wahrheitssuche' (2011) StV 559

Markesinis BS, Unberath $\mathrm{H}$ and Johnston A, The German Law of Contract: A Comparative Treatise (Hart Publishing 2006)

Marques ASP, 'A Colaboração Premiada: Um Braço Da Justiça Penal Negociada' (2014) 10 Revista Magister de Direito Penal e Processual Penal 32

Martín AN, 'Internal Investigations, Whistle-Blowing, and Cooperation: The Struggle for Information in the Criminal Process' in Stefano Manacorda, Francesco Centonze and Gabrio Forti (eds), Preventing Corporate Corruption (Springer 2014)

Martinez AP, 'Challenges Ahead of Leniency Programmes: The Brazilian Experience' (2015) 6 Journal of European Competition Law \& Practice 260

Marvão C, 'The EU Leniency Programme and Recidivism' (2016) 48 Review of Industrial Organization 1

__ , 'The EU Leniency Programme and Recidivism' (2016) 48 Review of Industrial Organization 1

Marvão C and Spagnolo G, 'What Do We Know about the Effectiveness of Leniency Policies? A Survey of the Empirical and Experimental Evidence' in Caron Beaton-Wells and Christopher Tran (eds), Anti-cartel enforcement in a contemporary age: leniency policies (Hart Publishing 2015)

Masson C and Marçal V, Crime Organizado (Método 2006)

Medinger JD, 'Antitrust Leniency Programs: A Call for Increased Harmonization as Proliferating Programs Undermine Deterrence' (2003) 52 Emory Law Journal 1439

Mehrens S, Die Kronzeugenregelung Als Instrument Zur Bekämpfung Organisierter Kriminalität: Ein Beitrag Zur Deutsch-Italienischen Strafprozessrechtsvergleichung (Max-Planck-Institut 2001)

Mello E and Spektor M, 'Brazil: The Costs of Multiparty Presidentialism' (2018) 29 Journal of Democracy 113

Melo MA, 'Crisis and Integrity in Brazil' (2016) 27 Journal of Democracy 50

Mendonça $\mathrm{AB}$ de, 'Os Benefícios Possíveis Na Colaboração Premiada: Entre a Legalidade e a Autonomia Da Vontade' in Maria Thereza de Assis Moura and Pierpaolo Cruz Bottini (eds), Colaboração premiada (Revista dos Tribunais 2017) 
Merrill TW and Smith HE, 'Optimal Standardization in the Law of Property: The Numerus Clausus Principle’ (2000) 110 Yale Law Journal 1

Miller NH, 'Strategic Leniency and Cartel Enforcement' (2009) 99 American Economic Association 750

Ministério Público Federal, 'Colaboração Premiada - Caso Lava Jato' <http://www. mpf.mp.br/para-o-cidadao/caso-lava-jato/atuacao-na-1a-instancia/investigacao/col aboracao-premiada $>$ accessed 28 September 2019

_- 'Relatório de Resultados Do Procurador-Geral Da República: Diálogo, Unidade, Transparência, Profissionalismo, Efetividade: 2015-2017’ (2017) <http:/ /www.mpf.mp.br/conheca-o-mpf/gestao-estrategica-e-modernizacao-do-mpf/sobr e/publicacoes/pdf/relatorio-gestao-pgr-2015-2017.pdf $>$ accessed 28 September 2019

—_ ' 'Orientação Conjunta No 1/2018: Acordos de Colaboração Premiada' (2018) $<$ http://www.mpf.mp.br/atuacao-tematica/ccr5/orientacoes/orientacao-conjuntano-1-2018.pdf> accessed 28 September 2019

Miriam Prelle, 'Opportunität Und Konsens: Verfahrensförmige Normsuspendierung Als Hilfe Für Die Überlast Im Kriminaljustizsystem?’ (2011) 94 Kritische Vierteljahresschrift für Gesetzgebung und Rechtswissenschaft 331

Misner RL, 'Recasting Prosecutorial Discretion' (1996) 86 Journal of Criminal Law and Criminology

Mistelis L, 'Regulatory Aspects: Globalization, Harmonization, Legal Transplants, and Law Reform - Some Fundamental Observations' (2000) 34 International Lawyer 1055

Moro SF, 'Preventing Systemic Corruption in Brazil' (2018) 147 Daedalus 157

Moss D, 'The Gift of Repentance: A Maussian Perspective on Twenty Years of Pentimento in Italy' (2001) 42 Archives Europeennes de Sociologie 297

Motchenkova E, 'Effects of Leniency Programs on Cartel Stability' (2004) Discussion Paper 2004-98 Center for Economic Research Tilburg University

Motta M and Polo M, 'Leniency Programs and Cartel Prosecution' (2003) 21 International Journal of Industrial Organization 347

Mulligan C, 'A Numerus Clausus Principle for Intellectual Property' (2012) 80 SSRN Electronic Journal 235

Musco E, 'Los Colaboradores de La Justicia Entre El Pentitismo y La Calumnia: Problemas y Perspectivas' (1998) 2 Revista Penal 35

Mushoff T, 'Die Renaissance Der Kronzeugenregelung' (2007) 90 Kritische Vierteljahresschrift für Gesetzgebung und Rechtswissenschaft 366

Nachbar JH, 'Prediction, Optimization, and Learning in Repeated Games' (1997) 65 Econometrica 275

Nagel S, Entwicklung Und Effektivität Internationaler Maßnahmen Zur Korruptionsbekämpfung (Nomos 2007) 
Naucke W, Der Begriff Der Politischen Wirtschaftsstraftat (LIT 2012)

Neira Pena AM, 'Corporate Criminal Liability: Tool or Obstacle to Prosecution?' in Dominik Brodowski and others (eds), Regulating corporate criminal liability (Springer 2014)

Nunes F and Melo CR, 'Impeachment, Political Crisis and Democracy in Brazil' (2017) 37 Revista de ciencia política 281

O'Brien A, 'Leadership of Leniency' in Caron Beaton-Wells and Christopher Tran (eds), Anti-cartel enforcement in a contemporary age: leniency policies (Hart Publishing 2015)

OECD, Brazil - Peer Review of Competition Law and Policy 2005 (OECD 2005)

OECD, 'Fighting Hard-Core Cartels: Harm, Effective Sanctions and Leniency Programmes' (OECD 2002)

—- Competition Law and Policy in Brazil - a Peer Review (OECD IDB 2010)

__, 'Leniency for Subsequent Applicants' (OECD 2012)

_- ' 'Use of Markers in Leniency Programs' (Working Party No. 3 on Co-operation and Enforcement, 2014) <http://www.oecd.org/officialdocuments/publicdisplayd ocumentpdf/?cote=DAF/COMP/WP3(2014)9\&doclanguage=en $>$ accessed 4 March 2019

Pacelli E, Curso de Processo Penal, vol 53 (Atlas 2013)

Paoli L, 'Mafia and Organised Crime in Italy: The Unacknowledged Successes of Law Enforcement' (2007) 30 West European Politics 854

Peglau J, ‘Überlegungen Zur Schaffung Neuer „Kronzeugenregelungen“’ (2001) 34 Zeitschrift für Rechtspolitik 103

Pereira FV, 'Compatibilização Constitucional Da Colaboração Premiada' (2013) Revista CEJ 84

—_, Delação Premiada: Legitimidade e Procedimento (Juruá Editora 2016)

Peters J, Urteilsabsprachen Im Strafprozess: Die Deutsche Regelung Im Vergleich Mit Entwicklungen in England \& Wales, Frankreich Und Polen (Universitätsverlag 2011)

Pieth M, 'The Harmonization of Law Against Economic Crime' (2013) 1 European Journal of Law Reform 527

Pinotti MC, 'Corrupção, Instituições e Estagnação Econômica: Brasil e Itália' in Maria Cristina Pinotti (ed), Corrupção: Lava Jato e Mãos Limpas (Portfolio-Penguin 2019)

Pizzi WT, 'Sentencing in the US: An Inquisitorial Soul in an Adversarial Body?' in John Jackson, Máximo Langer and Peter Tillers (eds), Crime, procedure and evidence in a comparative and international context (Hart Publishing 2008)

Polo M, 'Internal Cohesion and Competition among Criminal Organisations' in Gianluca Fiorentini and Sam Peltzman (eds), The Economics of Organised Crime (Cambridge University Press 1995)

Prado MM and Carson L, 'Corruption Scandals, the Evolution of Anti-Corruption Institutions, and Their Impact on Brazil's Economy' in Edmund Amann, Carlos R Azzoni and Werner Baer Print (eds), The Oxford Handbook of the Brazilian Economy (Oxford University Press 2018) 
Mosbacher A, 'Praktische Auswirkungen Der Entscheidung Des BVerfG Zur Verständigung' (2013) 2 BvR 201

Rabe P, Das Verständigungsurteil Des Bundesverfassungsgerichts Und Die Notwendigkeit von Reformen Im Strafprozess (Mohr Siebeck 2017)

Ribeiro DC, Cordeiro N and Guimarães DA, 'Interface between the Brazilian Antitrust, Anti-Corruption, and Criminal Organization Laws: The Leniency Agreements' (2016) 22 Law and Business Review of the Americas 195

Richter H, 'Zur Wirtschaftskriminalität' in Christian Müller-Gugenberger and Klaus Bieneck (eds), Wirtschafts-strafrecht: Handbuch des Wirtschaftsstraf- und -ordnungswidrigkeitenrechts (Verlag Dr Otto Schmidt Koln 2011)

Rödl F, 'Contractual Freedom, Contractual Justice, and Contract Law (Theory)' (2013) 76 Law and contemporary problems 57

Rodrigues Jr. OL, 'A doutrina do terceiro cúmplice: autonomia da vontade, o princípio res inter alios acta, função social do contrato e a interferência alheia na execução dos negócios jurídicos' (2004) 821 Revista dos Tribunais 80

Rosa AM da, 'A Aplicação Da Pena Na Justiça Negocia: A Questão Da Vinculação Do Juiz Aos Temos Da Delação', Sentença criminal e aplicação da pena: ensaios sobre discricionariedade, individualização e proporcionalidade (Juspodivm 2017)

Roxin C and Schünemann B, Strafverfahrensrecht: Ein Studienbuch (29th edn, CHBeck 2017)

Salditt F, 'Allgemeine Honorierung Besonderer Aufklärungshilfe' (2009) Strafverteidiger 375

Sarmento D, 'Colaboração Premiada. Competência Do Relator Para Homologação e Limites à Sua Revisão Judicial Posterior. Proteção à Confiança, Princípio Acusatório e Proporcionalidade', Direitos, democracia e República: escritos de direito constitucional (Fórum 2018)

Schemmel A, Corell C and Richter N, 'Plea Bargaining in Criminal Proceedings: Changes to Criminal Defense Counsel Practice as a Result of the German Constitutional Court Verdict of 19 March 2013?' (2014) 15 German Law Journal 43

Schiefler GHC, Diálogos Público-Privados: Da Opacidade à Visibilidade Na Administração Pública (Universidade de São Paulo 2016)

Schinkel MP, 'Forensic Economics in Competition Law Enforcement' (2008) 4 Journal of Competition Law and Economics 1

Schlüchter E, 'Erweiterte Kronzeugenregelung?’ (1997) 30 Zeitschrift für Rechtspolitik 65

Schünemann B, 'Die Verständigung Im Strafprozeß - Wunderwaffe Oder Bankrotterklärung Der Verteidigung?’ (1989) Neue Juristische Wochenschrift 1895

__, 'Gutachten, Kongressvortrag, Aufsatz | Absprachen Im Strafverfahren Grundlagen, Gegenstande Und Grenzen’ (1990) Deutscher Juristentag 58 b12

_- , 'Zur Kritik Des Amerikanischen Strafprozessmodells' in Edda Wesslau and Wolfgang Wohlers (eds), Festschrift für Gerhard Fezer zum 70. Geburtstag am 29. Oktober 2008 (De Gruyter 2008) 
__ ' 'Wohin Treibt Der Deutsche Strafprozess?' (2009) 114 Zeitschrift für die gesamte Strafrechtswissenschaft 1

__-, 'Die Zukunft Des Strafverfahrens - Abschied Vom Rechtsstaat?' (2007) 119 ZStW 945

-_-, 'Vom Unterschichts- Zum Oberschichtsstrafrecht: Ein Paradigmawechsel Im Moralischen Anspruch?' in Hans-Heiner Kühne and Koichi Miyazawa (eds), Alte Strafrechtsstrukturen und neue gesellschaftliche Herausforderungen in Japan und Deutschland (Duncker unb Humblot 2000)

Shapiro SP, 'Thinking about White Collar Crime: Matters of Conceptualization and Research' (1980) US Department of Justice, National Institute of Justice 1

-----, 'Collaring the Crime, Not the Criminal: Reconsidering the Concept of WhiteCollar Crime’ (1990) 55 American Sociological Review 346

Shavell S, 'Risk Sharing and Incentives in the Principal and Agent Relationship' (1979) 10 The Bell Journal of Economics 55

Silveira FAM, 'O Papel Do Juiz Na Homologação Do Acordo de Colaboração Premiada' (2018) 17 Revistas de Estudos Criminais 107

Simon J, Governing Through Crime: How the War on Crime Transformed American Democracy and Created a Culture of Fear, vol 12 (Oxford University Press 2009)

Simon J 'Governing Through Crime Metaphors', (2002) 67 Brooklyn Law Review 1035

Smith CW and Stulz RM, 'The Determinants of Firms' Hedging Policies' (1985) 20 The Journal of Financial and Quantitative Analysis 391

Smith R, Why Nations Fail: The Origins of Power, Prosperity, and Poverty, vol 157 (Crown Business 2012)

Souza AJG de, 'Colaboração Premiada: A Necessidade de Controle Dos Atos de Negociação' (2017) 25 Boletim IBCCRIM 12

Spagnolo G, 'Leniency and Whistleblowers in Antitrust' in Paolo Buccirossi (ed), Handbook of Antitrust Economics (The MIT Press 2008)

Spratling GR, 'Detection and Deterrence: Rewarding Informants for Reporting Violations’ (2001) 69 George Washington Law Review 798

Stephan A, 'An Empirical Assessment of the European Leniency Notice' (2008) 5 Journal of Competition Law and Economics 537

Stephan A and Nikpay A, 'Leniency Decision-Making from a Corporate Perspective: Complex Realities' in Caron Beaton-Wells and Christopher Tran (eds), Anti-Cartel Enforcement in a Contemporary Age: Leniency Policies (Hart Publishing 2015)

Stoffer H, Wie Viel Privatisierung "verträgt" Das Strasfprozessuale Ermittlungsverfahren? (Mohr Siebeck 2016)

Strang RR, 'Plea Bargaining, Cooperation Agreements and Immunity Orders.' (2014) 155th International Training Course Visiting Experts' Papers 
Stucke ME, 'Leniency, Whistle-Blowing and the Individual: Should We Create Another Race to the Competition Agency?' in Caron Beaton-Wells and Christopher Tran (eds), Anti-Cartel Enforcement in a Contemporary Age : Leniency Religion (Hart Publishing 2015)

Swenson T, 'The German "Plea Bargaining” Debate' (1995) 7 Pace International Law Review 373

Tak PJP, 'Deals with Criminals: Supergrasses, Crown Witnesses and Pentiti' (1997) 5 European Journal of Crime, Criminal Law and Criminal Justice 2

Teubner G, 'Legal Irritants: Good Faith in British Law or How Unifying Law Ends Up in New Divergencies' (2003) 61 The Modern Law Review 11

Thaman SC, 'Plea-Bargaining, Negotiating Confessions and Consensual Resolution of Criminal Cases' (2007) 113 Electronic Journal of Comparative Law 1

Tiedemann K, 'Der Entwurf Eines Ersteu Gesetzes Zur Bekämpfung Der Wirtschaftskriminalität' (1975) 87 Zeitschrift für die gesamte Strafrechtswissenschaft 253

Tourinho M, 'Brazil in the Global Anticorruption Regime' (2018) 61 Revista Brasileira de Politica Internacional 1

UNCTAD, 'The Use of Leniency Programmes as a Tool for the Enforcement of Competition Law against Hardcore Cartels in Developing Countries', Sixth United Nations conference to review all aspects of the set of multilaterally agreed equitable principles and rules for the control of restrictive business practices (UNCTAD 2010)

Vasconcellos VG de, Colaboração Premiada No Processo Penal (Revista dos Tribunais 2018)

------, Barganha e Justiça Criminal Negocial: Análise Das Tendências de Expansão Dos Espaços de Consenso No Processo Penal Brasileiro (Editora IBCCRIM 2014)

Vaughan D, 'The Dark Side of Organizations: Mistake, Misconduct, and Disaster' (1999) 25 Annual Review of Sociology 271

Vogel J, 'How to Determine Individual Criminal Responsibility in Systemic Contexts: Twelve Models' (2002) Cahiers de Défense Sociale 151

_- ' 'Chancen Und Risiken Einer Reform Des Strafrechtlichen Ermittlungsverfahrens' (2004) 59 JuristenZeitung 827

von Lampe K and Ole Johansen P, 'Organized Crime and Trust: On the Conceptualization and Empirical Relevance of Trust in the Context of Criminal Networks' (2004) 6 Global Crime 159

Watson A, Legal Transplants: An Approach to Comparative Law, vol 27 (Univesity of Georgia Press 1975)

__ ' 'From Legal Transplants to Legal Formats' (1995) 43 The American Journal of Comparative Law

Weigend T, 'Abgesprochene Gerechtigkeit - Effizienz Durch Kooperation Im Strafverfahren?’ (1990) 45 JuristenZeitung 774 
-_, Absprachen in Ausländischen Strafverfahren: Eine Rechtsvergleichende Untersuchung $\mathrm{Zu}$ Konsensualen Elementen Im Strafprozess (Eigenverl Max-Planck-Inst für ausländisches und internat Strafrecht 1990)

__ , 'Das „Opportunitätsprinzip " Zwischen Einzelfallgerechtigkeit Und Systemeffizienz' (1997) 109 Zeitschrift für die gesamte Strafrechtswissenschaft 103

__ , 'Unverzichtbares Im Strafverfahrensrecht' (2001) 113 Zeitschrift für die gesamte Strafrechtswissenschaft 271

__ , 'Neues Zur Verständigung Im Deutschen Strafverfahren?' in Leblois-Happe, Jocelyne/Stuckenberg and Carl-Friedrich (eds), Was wird aus der Hauptverhandlung? Quel avenir pour l'audience de jugement? (Boon University Press 2014)

Weigend T, 'The Decay of the Inquisitorial Ideal: Plea Bargaining Invades German Criminal Procedure' in John Jackson and others (eds), Crime, Procedure and Evidence in a Comparative and International Context (Hart Publishing 2008)

Weigend T and Turner JI, 'The Constitutionality of Negotiated Criminal Judgments in Germany' (2014) 15 German Law Journal 81

Weinstein I, 'Regulating the Market for Snitches' (1999) 47 Buffalo Law Review 563

Weir JA, 'Contract - Rights of Third Persons under Contracts to Which They Are Not Parties' (1943) 5 Alberta Law Quarterly 77

Weßlau E, 'Waffengleichheit Mit Dem»Organisierten Verbrechen«? Zu Den Rechtsstaatlichen Und Bürgerrechtlichen Kosten Eines Anti-OK-Sonderrechtssystems' (1997) 80 Kritische Vierteljahresschrift für Gesetzgebung und Rechtswissenschaft (KritV) 238

__, 'Wahrheit Und Legenden: Die Debatte Über Den Adversatorischen Strafprozess' (2014) 191 Zeitschrift für Internationale Strafrechtsdogmatik 558

Wheeler S and Rothman ML, 'The Organization as Weapon in White-Collar Crime' (1982) 80 Michigan Law Review 1403

Whitman J, 'No Right Answer' in John Jackson, Máximo Langer and Peter Tillers (eds), Crime, procedure and evidence in a comparative and international context: essays in honour of professor Mirjan Damaska (Hart Publishing 2008)

Wieling HJ, 'Venire Contra Factum Proprium Und Verschulden Gegen Sich Selbst' (1976) 176 Archiv für die civilistische Praxis 334

Wiener JB, 'Something Borrowed for Something Blue: Legal Transplants and the Evolution of Global Environmental Law' (2001) 27 Ecology Law Quarterly 1295

Wils WPJ, 'Leniency in Antitrust Enforcement: Theory and Practice' (2007) 24 Conferences on New Political Economy 203

__- 'Recidivism in EU Antitrust Enforcement: A Legal and Economic Analysis' (2012) 35 World Competition 5

Wils WPJ, 'The Use of Leniency in EU Cartel Enforcement: An Assessment after Twenty Years' (2016) 39 World Competition: Law and Economics Review 327

Winter B, 'Brazil's Never-Ending Corruption Crisis Why Radical Transparency Is the Only Fix' (2017) 96 Foreign Affairs 87 
Wunderlich A, 'Colaboração Premiada: O Direito à Impugnação de Cláusulas e Decisões Judiciais Atinentes Aos Acordos' in Maria Thereza de Assis Moura and Pierpaolo Cruz Bottini (eds), Colaboração premiada (Revista dos Tribunais 2017)

Zimmermann A, 'How Brazilian Judges Undermine the Rule of Law: A Critical Appraisal' (2008) 11 International Trade and Business Law Review 179 
